\title{
La violencia sexual a mujeres como constitutiva de tortura: la justicia de género en el Derecho Internacional de los Derechos Humanos.
}

María del Rosario Arrambide González Tesis de la Maestría en Derechos Humanos

Edición 2008-2009

Instituto de Derechos Humanos

Facultad de Ciencias Jurídicas y Sociales

Universidad Nacional de La Plata, Argentina 


\section{ÍNDICE}

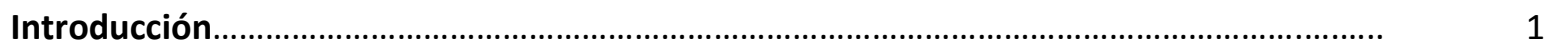

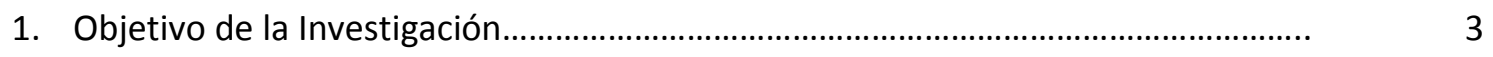

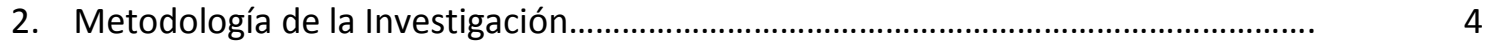

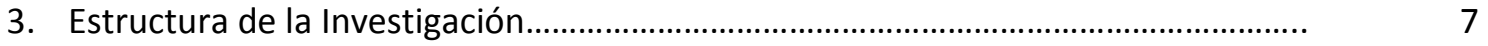

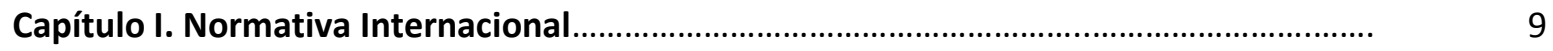

1. El derecho de las mujeres a una vida libre de violencia, incluida la prohibición de la tortura................................................................................................................ 9

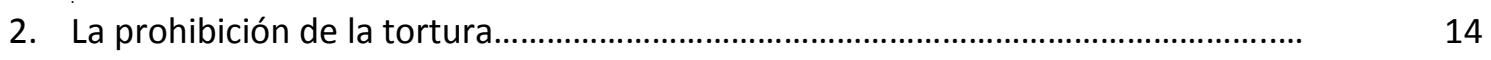

3. Obligaciones asumidas por los Estados en materia de derechos humanos............ 21

3.1 Obligaciones generales................................................................................... 22

3.2 Obligaciones específicas en materia de violencia contra las mujeres........... 28

3.3 Obligaciones específicas en materia de prohibición de la tortura.................. 35

Capítulo II. La Justicia de Género en los Tribunales Penales Internacionales ad hoc para Ruanda y la Ex Yugoslavia; Antecedentes que visibilizan la violencia sexual

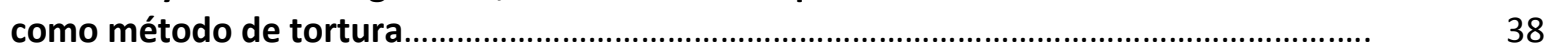

1. Tribunal Penal Internacional para Ruanda................................................................

1.1 Caso Akayesu, No. ICTR-96-4-T.........................................................................

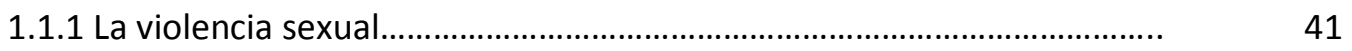

1.1.2 La violación sexual como constitutiva de tortura........................................ 43

1.1.3 Análisis de los principales aportes de la sentencia................................. 48

2. Tribunal Penal Internacional para la ex Yugoslavia....................................................... 52

2.1 Caso Furundzija, No. IT-95-17/1-PT........................................................................

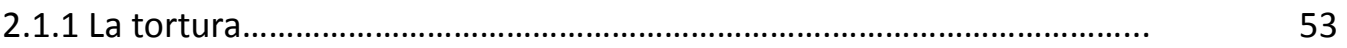

2.1.2 La violación sexual como constitutiva de tortura.................................... 55

2.1.3 Análisis de los principales aportes de la sentencia................................. 60

2.2 Caso Dragoljub Kunarac, Radomir Kovac y Zoran Vukovic, No. IT-96-23/1-A.. 62

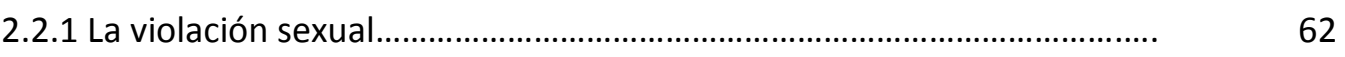

2.2.2 La violación sexual como constitutiva de tortura........................................ 65

2.2.3 Análisis de los principales aportes de la sentencia................................. 
1. Recomendaciones de la Comisión Interamericana de Derechos Humanos

1.1 Caso Rosa Marta Cerno Alfaro Vs. El Salvador

Informe de Fondo 10/92, del 04 de febrero de 1992

1.1.1 Resumen de los hechos...

1.1.2 Resolución de la Comisión

1.1.3 Análisis de los principales aportes de la resolución

1.2 Caso Flor de María Hernández Rivas Vs. El Salvador

Informe de Fondo 7/94, Caso 10.911, del 01 de febrero de $1994 .$.

1.2.1 Resumen de los hechos.

1.2.2 Resolución de la Comisión

1.2.3 Análisis de los principales aportes de la resolución

1.3 Caso Comadres Vs. El Salvador

Informe de admisibilidad y fondo 13/96, Caso 10.948, del 01 de marzo de 1996.

1.3.1 Resumen de los hechos

1.3.2 Resolución de la Comisión

1.3.3 Análisis de los principales aportes de la resolución

1.4 Caso Raquel Martín de Mejía Vs. Perú

Informe de admisibilidad y fondo 5/96, Caso 10.970, del 01 de marzo de 1996....

1.4.1 Resumen de los hechos

1.4.2 Resolución de la Comisión.

1.4.3 Análisis de los principales aportes de la resolución.

1.5 Caso Dianna Ortiz Vs. Guatemala

Informe de Fondo 31/96, Caso 10.526, del 16 de octubre de 1996

1.5.1 Resumen de los hechos

1.5.2 Resolución de la Comisión.

1.5.3 Análisis de los principales aportes de la resolución

1.6 Caso Ana, Beatriz y Celia González Pérez Vs. México

Informe de fondo 53/01, Caso 11.565, de 04 de abril de 2001

1.6.1 Resumen de los hechos

1.6.2 Resolución de la Comisión. 
1.7 Caso Gladys Carol Espinoza Gonzales Vs. Perú

Informe de Admisibilidad y Fondo 67/11, Caso 11.157, del 31 de marzo de

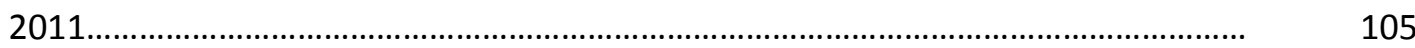

1.7.1 Resumen de los hechos...................................................................... 105

1.7.2 Resolución de la Comisión........................................................................ 107

1.7.3 Análisis de los principales aportes de la resolución................................. 113

2. Sentencias de la Corte Interamericana de Derechos Humanos.............................. 116

2.1 Caso Loayza Tamayo Vs. Perú

Sentencia de 17 de septiembre de 1997, Fondo.............................................................. 117

2.1.1 Resumen de los hechos........................................................................ 117

2.1.2 Sentencia de la Corte.............................................................................. 117

2.1.3 Análisis de los principales aportes de la sentencia.................................. 121

2.2 Caso Penal Castro Castro Vs. Perú

Sentencia de 25 de noviembre de 2006, Fondo, Reparaciones y Costas................ 122

2.2.1 Resumen de los hechos................................................................................ 123

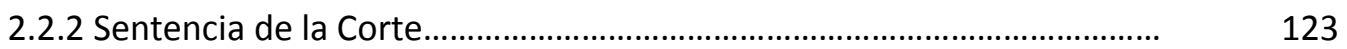

2.2.3 Análisis de los principales aportes de la sentencia.................................. 132

2.3 Caso González y Otras "Campo Algodonero" Vs. México

Sentencia de 16 de noviembre de 2009, Excepción preliminar, Fondo, Reparaciones y Costas................................................................................................ 134

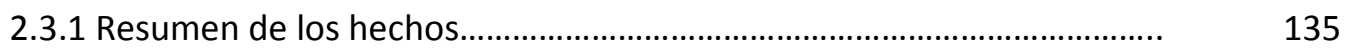

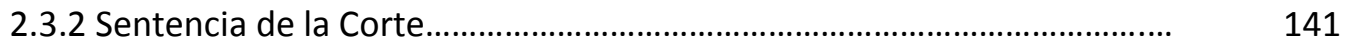

2.3.3 Análisis de los principales aportes de la sentencia.................................. 151

2.4 Caso Inés Fernández Ortega Vs. México

Sentencia de 30 de agosto de 2010, Excepción preliminar, Fondo, Reparaciones y Costas................................................................................................................... 153

2.4.1 Resumen de los hechos........................................................................ 154

2.4.2 Sentencia de la Corte.................................................................................. 155

2.4.3 Análisis de los principales aportes de la sentencia................................. 159

2.5 Caso Valentina Rosendo Cantú Vs. México

Sentencia de 31 de agosto de 2010, Excepción preliminar, Fondo, Reparaciones

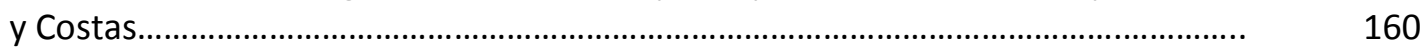

2.5.1 Resumen de los hechos....................................................................... 161

2.5.2 Sentencia de la Corte.............................................................................. 162

2.5.3 Análisis de los principales aportes de la sentencia.................................... 168 
2.6 Caso J. Vs. Perú

Sentencia de 27 de noviembre de 2013, Excepción Preliminar, Fondo, Reparaciones y Costas........................................................................................... $\quad 170$

2.6.1 Resumen de los hechos.................................................................... 171

2.6.2 Sentencia de la Corte................................................................................. 176

2.6.3 Análisis de los principales aportes de la sentencia................................ 183

Capítulo IV. La Justicia de Género en el Sistema de Naciones Unidas............................... 187

1. Caso Encarnación Blanco Abad v. España, Comunicado № 59/1996....................... 191

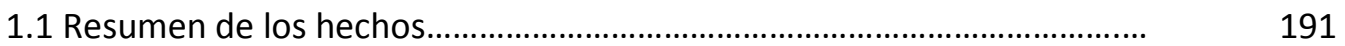

1.2 Resolución del Comité contra la Tortura....................................................... 192

2.1.3 Análisis de los principales aportes de la resolución.................................. 194

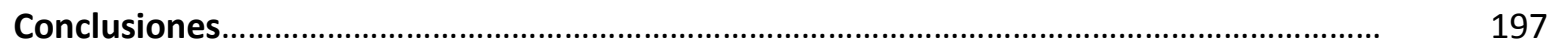

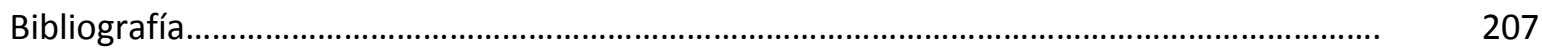

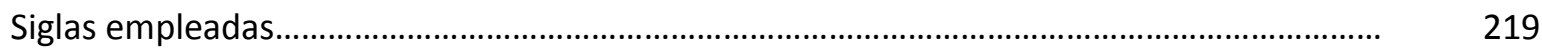




\section{Introducción}

El empleo de la violencia sexual contra las mujeres como mecanismo de tortura es un reflejo de las relaciones desiguales de poder entre los géneros, un acto de poder arbitrario perpetrado por los aparatos coercitivos del Estado o bien por particulares bajo la aquiescencia del mismo. Ésta ha sido y sigue siendo una práctica estratégica utilizada con el objetivo de controlar, someter, castigar u obtener la confesión de las mujeres, así como para ejercer presión, intimidar y debilitar la fuerza de los movimientos sociales y/o políticos. A lo largo de la historia se ha empleado como estrategia de poder en contra de mujeres y niñas, quienes se encuentran ante situaciones de mayor vulnerabilidad ante la violación de sus derechos humanos, por su condición de género.

La violencia sexual es empleada como método de tortura para la obtención de diversos fines y como estrategia contrainsurgente, ${ }^{1}$ donde el cuerpo de las mujeres se convierte en campo de batalla y la violencia sexual un arma de terror. Pero en todos los casos, no es otra cosa, sino una manifestación de las relaciones desiguales de poder y de la dominación patriarcal sobre las mujeres, su cuerpo y sexualidad.

La violencia sexual es una realidad que afecta permanentemente a las mujeres y exacerba patrones de discriminación de género, donde los cuerpos de las mujeres se convierten en trofeos de guerra. Mediante la violencia sexual se busca demostrar el poder y dominación sobre los varones de las zonas afectadas, se envía un mensaje de humillación a través de los cuerpos violentados de las mujeres. ${ }^{2}$

\footnotetext{
${ }^{1}$ Por estrategia contrainsurgente, se hace referencia a cualquier medida o política empleado por el Estado y que tiene por objetivo reprimir y contrarrestar la fuerza de los grupos insurgentes y de las organizaciones sociales y políticas. En este sentido, la Comisión para el Esclarecimiento Histórico en Guatemala, se refiere a las operaciones contrainsurgentes, como aquellas que se planifican e implementan a través de diversas operaciones militares para la eliminación del enemigo interno, definido por el ejército. Mismas que producen violaciones a los derechos humanos y terror en la población, tales como: las operaciones de tierra arrasada, de desplazamiento, de castigo, de control y de aniquilamiento de población civil, acciones militares encubiertas, de inteligencia y operaciones psicológicas. Véase "GUATEMALA: Memoria del silencio: Informe de la Comisión para el Esclarecimiento Histórico (CEH)", Capitulo II, Volumen I: Estrategias y mecanismos de las partes; Las estrategias contrainsurgentes durante el conflicto armado, párrafos 12 y 13,1999

${ }^{2}$ DEMUS, Estudio para la Defensa de los Derechos de la Mujer, Justicia de Género. Violencia sexual en conflictos armados: el derecho de las mujeres a la justicia, Agencia Española de Cooperación Internacional, Lima, septiembre de 2008, p. 3
} 
En el ámbito del Derecho Internacional, fue hasta hace pocos años ${ }^{3}$ que dicha problemática tomó importancia, convirtiéndose en tema de la agenda internacional y abordándose tales atrocidades como prácticas internacionalmente reprobables que no pueden permanecer impunes. ${ }^{4}$ Así, ha resultado de gran avance que al juzgarse ciertos casos por parte de los Tribunales Internacionales, éstos se hayan equiparado a tortura. La importancia de tipificar estos actos como constitutivos de tortura, consiste en visualizar el objeto y finalidad con la que es empleada la violencia sexual por parte de los Estados. Es decir, permite identificar la intencionalidad estratégica en su perpetración para la obtención de ciertos fines, lo que conllevaría a evidenciar su comisión como una práctica estratégica común de los Estados.

La no visualización de esta forma de violencia, tiene que ver con aspectos culturales que fomentan la violencia de género, pues el desarrollo de las teorías feministas han señalado que el acceso al cuerpo de las mujeres a través de la violencia sexual, ha sido y sigue siendo un instrumento de poder y represión legitimado y empleado tanto por particulares, como por agentes estatales, quienes bajo la figura de autoridad y haciendo uso arbitrario del poder, someten a las mujeres ejerciendo violencia en sus distintas modalidades, entre ellas la violencia sexual. Ésta resulta una práctica sistemática y generalizada, perpetrada y tolerada por los Estados, tanto en el marco de violencia armada, como de otras violaciones a los derechos humanos.

En el ámbito del Derecho Internacional de los Derechos Humanos, los organismos internacionales de protección a los derechos humanos, sobre todo en el ámbito regional o interamericano, han conocido diversas peticiones por casos de violencia sexual contra mujeres. Es a través de sus resoluciones o sentencias que han generado estándares de protección al derecho de las mujeres a una vida libre de violencia, pero sobre todo, que permiten encuadrar o tipificar los actos de violencia sexual como constitutivos de tortura.

\footnotetext{
${ }^{3}$ MOREYRA menciona que fue hasta la década de los 90 con el conflicto de la ex Yugoslavia, que la violencia sexual contra mujeres durante los conflictos armados, se colocó en la agenda de la comunidad internacional. En MOREYRA, María julia, Conflictos armados y violencia sexual contra mujeres, Editores del Puerto, Buenos Aires 2007, P. 193

${ }^{4}$ ALIJA Fernández, Rosa Ana, Crímenes de Derecho Internacional y Derechos de la Mujer: De la protección del Honor a la Salvaguarda de la Libertad, en Colección Género, Derecho y Justicia: Derechos de las Mujeres en Derecho Internacional, coordinadores Juan A. Cruz Parcero y Rodolfo Vásquez, editorial fontamara, segunda edición, México, 2012, p.112
} 
En el caso de México, existen varias denuncias por violencia sexual contra mujeres como método de tortura, perpetrada por agentes del Estado o particulares con la aquiescencia del mismo. En la mayoría, se observa que la violencia sexual es perpetrada con la finalidad de obtener confesiones, o bien como método de castigo.

Sin embargo, existe un alto desconocimiento de los instrumentos y estándares internacionales en materia de derechos humanos y en específico de los derechos humanos de las mujeres, lo que conlleva a la inaplicabilidad de éstos en la defensa de los casos.

La necesidad de aplicar los instrumentos y estándares internacionales cobra mayor sentido a partir de la reforma constitucional en materia de derechos humanos en México, publicada en el Diario Oficial de la Federación el 10 de junio de 2011, en donde los tratados internacionales adquieren jerarquía constitucional y se incorporan los criterios de "Interpretación conforme" y "principio pro persona", así como las obligaciones de las autoridades en la materia y los principios generales de los derechos humanos.

\section{Objetivo de la Investigación}

La presente investigación tiene por objeto detectar y sistematizar por un lado los instrumentos internacionales en materia de derechos humanos de las mujeres y la obligaciones que de éstos se derivan, y por el otro los estándares jurisprudenciales que puedan emplearse como criterios orientadores y de interpretación para la defensa de los derechos humanos de las mujeres, en los casos en que la violencia sexual es empleada como mecanismo de tortura.

Lo anterior, permitirá a su vez observar la evolución sobre todo en el Sistema Interamericano de Derechos Humanos, para juzgar con perspectiva de género, o bien, emplear en su análisis un enfoque de género para resolver dichos casos, así como la evolución en el análisis y creación de estándares respecto a la tortura y violencia sexual. 
Con ello se pretende aportar una herramienta que pueda ser empleada en la defensa de los derechos humanos de las mujeres, principalmente el derecho a una vida libre de violencia sexual y de tortura, a través de la sistematización de los principales criterios orientadores y jurisprudenciales que permiten proveer una protección más amplia a los derechos de las mujeres.

\section{Metodología de la Investigación}

La metodología de la presente investigación consistió en un análisis de tipo cualitativo, para ello se detectaron, sistematizaron y analizaron diversas fuentes documentales.

La revisión de dichas fuentes se llevó a cabo mediante tres procesos, el primero vinculado al análisis de diversa bibliografía relacionada con el campo de estudio, el segundo consistió en detectar y sistematizar los principales instrumentos internacionales en materia de derechos humanos de las mujeres y tortura, los precedentes jurisprudenciales en materia de violencia sexual emitidos por los Tribunales Penales Internacionales ad hoc para la ex Yugoslavia y Ruanda, las recomendaciones de la Comisión Interamericana de Derechos Humanos, las Sentencias de la Corte Interamericana de Derechos Humanos y las resoluciones de los Comités de las Naciones Unidas, estas tres últimas relacionadas también con casos de violencia sexual como tortura.

En cuanto a los precedentes emitidos por los Tribunales Penales Internacionales ad hoc para la ex Yugoslavia y Ruanda, se analizaron los más importantes a criterio de la investigadora, por ser aquellos que marcaban una pauta en el cambio de concepción y visualización de la violencia sexual contra las mujeres, sin embargo, es importante reconocer que existe una diversidad de sentencias que a su vez aportan estándares importantes para la defensa de los derechos humanos de las mujeres, en específico vinculados con la violencia sexual, pero debido a la extensa cantidad de las mismas, no todas pudieron ser abordadas en la presente investigación, tratando de centrarse en las más relevantes y que marcaron un hito histórico en la visualización de la violencia sexual contra las mujeres. 
Por otra parte en cuanto a la ubicación y sistematización de las recomendaciones y sentencias de la Comisión y la Corte Interamericana de Derechos Humanos, se situaron todas las relacionadas con casos de violencia sexual y tortura, con corte al año 2013.

Respecto a las recomendaciones de los Comités de la ONU creados en virtud de los tratados, se buscaron en el Comité de Derechos Humanos, el Comité para la Eliminación de la Discriminación contra la Mujer y el Comité contra la Tortura, con corte al año 2013, encontrándose únicamente en el último Comité.

Finalmente, la tercera etapa del proceso consistió en analizar la documentación detectada y sistematizada, comenzando por la evolución de los instrumentos internacionales en materia de derechos humanos de las mujeres y las obligaciones que de éstos derivan, seguido del análisis progresivo de los distintos estándares internacionales y/o jurisprudenciales emitidos por los Tribunales ad hoc, la Comisión y la Corte Interamericana y el Comité contra la Tortura.

Dicho análisis se centró en la evolución y perfeccionamiento de la justicia de género a través de las sentencias y recomendaciones, es decir, de qué forma se fue haciendo frente a las desigualdades históricas y estructurales (vinculadas a la violencia sexual contra mujeres) a través de la impartición de justicia a nivel internacional y en qué medida los Órganos mencionados evolucionaron sus estándares partiendo de un enfoque génerosensitivo que tomara en cuenta las siguientes líneas de acción:

a) Eliminar prejuicios de género cimentados en patrones socio-culturales de conducta asignados a hombres y mujeres por su sexo y basados en esquemas de superioridad e inferioridad;

b) Hacer frente a las normas y a la interpretación y aplicación del derecho en el ámbito interno de los países basada en prejuicios de género;

c) Tomar en cuenta las especificidades sexuales y genéricas para garantizar la igualdad a partir de las diferencias. 
d) Contrarrestar acciones y conductas sustentadas en estereotipos, y violatorias al derecho a la igualdad y no discriminación.

En otras palabras, al referirme a la justicia de género en la presente investigación se hace alusión a la forma en que los operadores de justicia de los Órganos Internacionales garantizan el derecho a la igualdad a partir de las diferencias sexuales y las construcciones socioculturales asociadas al género.

O bien, retomando el análisis de Alda Facio respecto al fenómeno legal, se podría decir que la justicia de género debe enfrentar los tres componentes que forman al fenómeno jurídico: el componente formal-normativo; el componente estructural; y el componente políticocultural.

El primero es la ley formalmente promulgada, el segundo es el contenido que los operadores de justicia o cualquier servidor público da a la ley al aplicarlas o interpretarlas, es decir leyes no escritas, y el último es el contenido y significado que se le va dando a la ley por medio de la doctrina jurídica, las costumbres, actitudes, tradiciones y conocimiento que la gente tenga de la ley, así como el uso que la gente haga de las leyes existentes; de las que en la vida diaria siguen vigentes aunque hayan sido derogadas y de las relaciones entre las leyes escritas y las no escritas ${ }^{5}$.

Donde estos tres componentes se retroalimentan y se influencian entre sí, por ejemplo, la creación de las leyes (componente formal-normativo) está influenciada por los otros dos componentes, donde quien crea la ley lo hace a partir de su interpretación, es decir de la leyes no escritas (componente estructural) y del contenido y significado que se ha dado a las leyes escritas o no (componente estructural), pero ambos impregnados por prejuicios y estereotipos de género. Esta triple influencia puede observarse al analizar cualquiera de los otros dos componentes.

${ }^{5} \mathrm{FAClO}, \mathrm{Alda}$, Cuando el género suena, cambios trae. Una metodología para el análisis de género del fenómeno legal, ILANUD, 1991, p. $65-66$ 
Por tanto, el presente análisis se basa en detectar en qué medida se hace frente a los factores mencionados con antelación en los distintos estándares internacionales y/o jurisprudenciales emitidos por los Tribunales ad hoc, la Comisión y la Corte Interamericana y el Comité contra la Tortura.

\section{Estructura de la Investigación}

La presente investigación está estructurada por cuatro capítulos.

En el primer capítulo se sistematizan y analizan los principales instrumentos internacionales tanto del Sistema Universal de Derechos Humanos, como del Regional o Interamericano, que protegen los derechos humanos de las mujeres y la tortura, detectándose también las principales obligaciones adquiridas por los Estados.

En este capítulo se da cuenta de la evolución histórica a través de la adopción de diversos instrumentos, desde aquellos de carácter genérico, hasta los específicos, con la finalidad de reforzar la protección de los derechos de las mujeres, en específico la violencia sexual y la tortura.

En el segundo capítulo se sistematizan y analizan los principales precedentes jurisprudenciales emitidos por los Tribunales Penales Internacionales ad hoc para la ex Yugoslavia y Ruanda, que permitieron visualizar la violencia sexual contra las mujeres y que marcaron un hito histórico para la defensa de los derechos humanos de las mujeres.

El tercer capítulo se aboca a la sistematización y análisis de las recomendaciones emitidas por la Comisión Interamericana de Derechos Humanos y las Sentencias de la Corte Interamericana, todas ellas relacionadas a casos de violencia sexual contra las mujeres como método de tortura. De esta forma se ubicaron los principales estándares tanto de interpretación, como jurisprudenciales, que pueden ser empleados en la defensa de los derechos humanos de las mujeres, pero a su vez se realiza un análisis de la evolución de la justicia de género o empleo de un enfoque género- sensitivo en las resoluciones de ambos Órganos que contribuye evidentemente a la protección de los derechos de las mujeres. 
Por último, el cuarto capítulo sistematiza y analiza la única recomendación vinculada a la obligación de investigar hechos de tortura por violencia sexual y ubicada en el seno de los Órganos creados en virtud de los tratados de las Naciones Unidas, en este caso tratándose del Comité contra la Tortura. 


\section{Capítulo I}

\section{Normativa internacional}

\section{El derecho de las mujeres a una vida libre de violencia, incluida la prohibición de la tortura}

En el ámbito del Derecho Internacional de los Derechos Humanos, la protección del derecho de las mujeres a una vida libre de violencia ha sido un desafío para los Sistemas de Protección de los Derechos Humanos, tanto a nivel Universal, como Regional.

Los primeros instrumentos internacionales que se adoptaron en materia de derechos humanos son denominados instrumentos generales, pues su ámbito de protección va dirigido a la protección de todos los derechos humanos, para todos los seres humanos, sin hacer distinciones positivas a favor de determinado sector de población o al ámbito de protección de determinado derecho, como es la prohibición de la tortura. Es decir, estos instrumentos no abarcan de forma específica el derecho de las mujeres a una vida libre de violencia, pues éste se encuentra inscrito dentro del derecho a la vida y a la integridad personal inherente a toda persona.

Como parte de estos instrumentos generales se ubican, la Declaración Universal de los Derechos Humanos y la Declaración Americana de Derechos y Deberes del Hombre, ambas adoptadas en 1948, la primera por la Organización de las Naciones Unidas (en adelante ONU) y la segunda por la Organización de los Estados Americanos (en adelante OEA).

En cuanto a instrumentos generales vinculantes, encontramos el Pacto Internacional de Derechos Civiles y Políticos (en adelante PIDCP) adoptado en 1966 por la ONU y la Convención Americana sobre Derechos Humanos (en adelante CADH) adoptada en 1969 por OEA. El primero no contempla como tal, el derecho a la integridad personal, ubicándose únicamente la prohibición de la tortura, penas o tratos crueles, inhumanos o 
degradantes, en su artículo 7. Por su parte la $\mathrm{CADH}$ protege el derecho a la integridad física, psíquica y moral, y la prohibición de la tortura en su artículo 5.

A pesar de que el derecho a la integridad personal se encontraba ya protegido por estos instrumentos generales, la situación de la violencia y discriminación contra las mujeres, debido a su incidencia y por tratarse de un problema multifacético, requería de un tratamiento específico que se abordara desde una perspectiva de género. Por ello, y para hacer frente a esta problemática, la Comunidad Internacional impulsada por las organizaciones de mujeres y feministas comenzó a desarrollar instrumentos específicos de carácter vinculante, que tomaran en cuenta las causas y consecuencias de las violaciones a los derechos humanos de las mujeres (incluida la violencia) y que contemplaran obligaciones muy puntuales para los Estados.

"Los derechos de las mujeres se inscriben así en un proceso de especificación de los derechos humanos, el cual ha supuesto la progresiva sensibilización del derecho internacional, como también de los derechos nacionales, hacia las personas y los colectivos de personas cuyos derechos humanos están expuestos a violaciones específicas o que requieren de una protección reforzada. En el caso de las mujeres, patrones históricos y universales de violación de los derechos humanos en razón del género, manifestados en la discriminación y en la violencia contra las mujeres, así como la falta de acceso a y de disfrute de los derechos sexuales y reproductivos, han hecho que los sistemas internacionales y nacionales de protección de los derechos humanos se hayan orientado a proteger a las mujeres de manera cada vez más precisa."

Como resultado de dicho proceso, se adoptaron dos instrumentos que se correlacionan entre sí, la Convención sobre la Eliminación de todas las formas de Discriminación contra la Mujer $^{7}$ [CEDAW por sus siglas en Inglés], adoptada en el seno de la ONU y la

\footnotetext{
${ }^{6}$ GARCÍA Muñoz, Soledad, Género y Derechos Humanos de las Mujeres: Estándares conceptuales y normativos en clave de derecho internacional, en Colección Género, Derecho y Justicia: Derechos de las Mujeres en Derecho Internacional, coordinadores Juan A. Cruz Parcero y Rodolfo Vásquez, editorial fontamara, segunda edición, México, 2012, p. 48-49

${ }^{7}$ Adoptada en New York el 18 de diciembre de 1979
} 
Convención Interamericana para Prevenir, Sancionar y Erradicar la Violencia contra las Mujeres $^{8}$ [Convención de Belém do Pará, o Belém do Pará], la cual forma parte del Sistema de Protección Regional Interamericano, es decir el Sistema Interamericano de Derechos Humanos.

La CEDAW es adoptada por la Asamblea General de la ONU en 1979 y entra en vigor en 1981 una vez que alcanza el número de ratificaciones necesarias. Este instrumento tiene por objeto que los Estados Parte adopten las medidas necesarias para suprimir la discriminación contra la mujer en todas sus formas y manifestaciones, en este sentido, define la discriminación como:

“...toda distinción, exclusión o restricción basada en el sexo que tenga por objeto o resultado menoscabar o anular el reconocimiento, goce o ejercicio por la mujer, independientemente de su estado civil, sobre la base de la igualdad del hombre y la mujer, de los derechos humanos y las libertades fundamentales en las esferas política, económica, social, cultural y civil o en cualquier otra esfera." ${ }^{\prime 9}$

Tal definición comprende toda diferencia de trato basada en el sexo que intencionalmente o en la práctica coloque a las mujeres en situación de desventaja o impida el pleno reconocimiento de sus derechos humanos en las esferas públicas y privadas. ${ }^{10}$

Si bien la definición de discriminación contra la mujer no hace referencia explícita a la violencia contra las mujeres, el alcance de protección del derecho a la no discriminación es desarrollado e interpretado posteriormente por el Comité para la Eliminación de la Discriminación contra la Mujer, dicho comité CEDAW es el órgano encargado de la supervisión de la Convención, quien en su Recomendación General No. 19 establece:

"La violencia contra la mujer es una forma de discriminación que impide gravemente que goce de derechos y libertades en pie de igualdad con el hombre... [Y observa

\footnotetext{
${ }^{8}$ Adoptada en Belém do Pará, Brasil el 06 de septiembre de 1994

${ }^{9} \mathrm{ONU}$, Convención sobre la Eliminación de todas las formas de Discriminación contra la Mujer, art. 1

${ }^{10}$ OEA, Comisión Interamericana de Derechos Humanos, Acceso a la Justicia para Mujeres Víctimas de Violencia Sexual en Mesoamérica, OEA/Ser.L/V/II., 09 de diciembre de 2011, párr. 30
} 
también que la definición de discriminación incluye]... la violencia basada en el sexo, es decir, la violencia dirigida contra la mujer porque es mujer, o que la afecta en forma desproporcionada... [Y que] la violencia contra la mujer puede contravenir disposiciones de la Convención, sin tener en cuenta si hablan expresamente de la violencia." $^{11}$

De esta forma se desarrolla en el marco jurídico internacional, la correlación entre la violencia y la discriminación contra las mujeres, ambas en detrimento del goce y ejercicio de los derechos humanos y libertades fundamentales de las mujeres.

"A partir de la CEDAW, la discriminación y violencia que padecen las mujeres en sus vidas privadas, en el marco de sus vínculos familiares y personales, es sancionada y puede conllevar responsabilidad internacional para los Estados Parte, si no protegen adecuadamente a las mujeres de la discriminación dentro de sus fronteras. "12

Destaca también la obligación que asumen los Estados en cuanto a modificar patrones socioculturales de conducta de hombres y mujeres, basados en la idea de superioridad e inferioridad de los sexos (art. 5), pues ello implica un deber por parte de los mismos de contrarrestar las relaciones desiguales de poder, que se expresan a través del ejercicio de la violencia y el acceso al cuerpo de las mujeres, como es el caso de la violencia sexual.

Otro instrumento del Sistema Universal de Protección a Derechos Humanos que aborda el derecho de las mujeres a una vida libre de violencia, es la Declaración sobre la Eliminación de la Violencia contra la Mujer ${ }^{13}$. Si bien este instrumento carece de carácter vinculante por tratarse de una declaración enunciativa de derechos, sí implica compromisos políticos y morales para los Estados, por lo que su cumplimiento dependerá de la voluntad política de éstos.

\footnotetext{
${ }^{11}$ ONU, Recomendación General No. 19, adoptada por el Comité para la Eliminación de la Discriminación contra la Mujer, $11^{\circ}$ periodo de sesiones, 1992, U.N. Doc. HRI\GEN\1\Rev.1 at 84 (1994), párr. 1 y 6

${ }^{12}$ Instituto Interamericano de Derechos Humanos y Centro por la Justicia y el Derecho Internacional, Los derechos humanos de las mujeres: Fortaleciendo su promoción y protección internacional, San José, Costa Rica, Agosto 2004, p. 134

${ }^{13}$ Adoptada por la Asamblea General de las Naciones Unidas el 20 de diciembre de 1993
} 
Por su parte, la Convención de Belém do Pará se adopta el 09 de junio de 1994 y entra en vigor en 1995. Este instrumento define la violencia contra la mujer como:

“... cualquier acción o conducta, basada en su género, que cause muerte, daño o sufrimiento físico, sexual o psicológico a la mujer, tanto en el ámbito público como en el privado." 14

Asimismo, desarraiga la idea de que la violencia contra la mujer se circunscribe exclusivamente al ámbito privado, estableciendo así diversos ámbitos de alcance de la violencia contra las mujeres, en el siguiente sentido:

“...que tenga lugar dentro de la familia o unidad doméstica o en cualquier otra relación interpersonal, ya sea que el agresor comparta o haya compartido el mismo domicilio que la mujer...; que tenga lugar en la comunidad y sea perpetrada por cualquier persona (...) en el lugar de trabajo, así como en instituciones educativas, establecimientos de salud o cualquier otro lugar, y (...) que sea perpetrada o tolerada por el Estado o sus agentes, dondequiera que ocurra."15

El alcance de esta disposición ha sido un gran aporte a la defensa de los derechos humanos de las mujeres, en la medida en que su homologación al ámbito jurídico interno de los Estados Parte de la Convención, ha generado reformas legales que incluyan la violencia institucional (perpetrada por el Estado o sus agentes) contra las mujeres, donde se ubicarían los casos de violencia sexual como tortura, perpetrados por agentes estatales.

La Convención de Belém do Pará refiere también el nexo entre la violencia y la discriminación hacia las mujeres, estableciendo que el derecho de la mujer a una vida libre de violencia incluye el derecho a ser libre de toda forma de discriminación. ${ }^{16}$

Respecto a su ámbito de protección, la Convención de Belém do Pará hace referencia a una serie de derechos protegidos, ${ }^{17}$ dentro de estos la analogía entre el derecho a una

\footnotetext{
${ }^{14}$ OEA, Convención Interamericana para Prevenir, Sancionar y Erradicar la Violencia contra las Mujeres, art. 1

${ }^{15}$ Ibídem., art. 2

${ }^{16}$ Ibíd., art. 6
} 
vida libre de violencia (incluida la discriminación) y la prohibición de la tortura, se ubica en: el derecho de toda mujer a una vida libre de violencia, tanto en el ámbito público como en el privado (art. 3); el derecho a que se respete su vida (art. 4a); el derecho a que se respete su integridad física, psíquica y moral (art. 4b); el derecho a la libertad y a la seguridad personal (art. 4c); el derecho a no ser sometida a torturas (art.4d) y; el derecho a que se respete la dignidad inherente a su persona y que se proteja a su familia(art. $4 \mathrm{e})$.

Ambos instrumentos además de contemplar un catálogo de derechos protegidos, contemplan una serie de obligaciones que asumen los Estados parte desde el momento de ratificar dichas convenciones.

\section{La prohibición de la tortura}

Por su parte, la prohibición de la tortura comenzó a abordarse en los instrumentos generales de derechos humanos en forma meramente enunciativa, es decir, prohibían la comisión de la misma, pero sin dar una definición de ésta, como sucede más adelante en los instrumentos específicos de tortura.

Fue a partir del 10 de diciembre de 1948, con la adopción de la Declaración Universal de Derechos Humanos, mediante resolución 217 A (III), de la Asamblea General de las Naciones Unidas, que se abordó por la comunidad internacional la prohibición de la tortura, a diferencia de la Declaración Americana de Derechos y Deberes del Hombre ${ }^{18}$ del Sistema Regional Interamericano, que no aborda como tal la tortura, pudiéndose entender que ésta se encuentra circunscrita al ámbito de protección de la seguridad personal, contemplada en su artículo 1.

La Declaración Universal de Derechos Humanos establece en su artículo 5 que:

\footnotetext{
${ }^{17}$ Ibid., art. 3 y 4

${ }^{18}$ Aprobada en la Novena Conferencia Internacional Americana, en Bogotá Colombia en 1948
} 
"Nadie será sometido a torturas ni a penas o tratos crueles, inhumanos o degradantes." 19

Posteriormente, se aborda la prohibición de la tortura en el marco de los instrumentos internacionales generales de carácter vinculante, es decir, los pactos y convenciones, entre éstos el PIDCP y la CADH.

Ambos instrumentos abordan un catálogo de derechos y una serie de obligaciones generales que asumen los Estados con su ratificación, comprometiéndose a respetar y garantizar los derechos reconocidos, así como adoptar las medidas necesarias para hacerlos efectivos. Es en el catálogo de derechos que encontramos la prohibición de la tortura, en el caso del Sistema Interamericano de forma complementaria al derecho a la integridad personal y en el siguiente sentido:

"Nadie debe ser sometido a torturas ni a penas o tratos crueles, inhumanos o degradantes. Toda persona privada de libertad será tratada con el respeto debido a la dignidad inherente al ser humano."20

Por su parte, el Pacto también refiere la prohibición de ser sometido sin el libre consentimiento a experimentos médicos o científicos, lo cual tiene su razón de ser en la serie de atrocidades que se cometieron en los centros de concentración de la segunda guerra mundial, donde se violó la dignidad humana, justificando el posible avance científico.

"Nadie será sometido a torturas ni a penas o tratos crueles, inhumanos o degradantes. En particular, nadie será sometido sin su libre consentimiento a experimentos médicos o científicos. "21

\footnotetext{
${ }^{19}$ ONU, Declaración Universal de Derechos Humanos, art. 5

${ }^{20}$ OEA, Convención Americana sobre Derechos Humanos, art. 5.2

${ }^{21}$ ONU, Pacto Internacional de Derechos Civiles y Políticos, art. 7
} 
Estos instrumentos establecen la prohibición de la tortura en el marco de los derechos humanos protegidos, sin embargo, no establecen una definición de los actos que la constituyen, ni la diferencia con las penas o tratos crueles, inhumanos o degradantes.

Un aspecto a destacar de estos instrumentos generales es que no establecen el requisito de que la tortura sea perpetrada por agentes estatales o bajo la tolerancia o aquiescencia de estos. Lo que ha sido de gran controversia, pues pareciera que los instrumentos específicos de prohibición de la tortura limitan su comisión a los agentes estatales, donde los particulares no encuadran dentro de la responsabilidad.

Sin embargo, es necesario recordar que el Derecho Internacional de los Derechos Humanos contempla obligaciones para los Estados, con relación a los particulares. Si bien es cierto, los derechos humanos deben ser respetados por los particulares y el Estado debe velar por que así sea, también es cierto que los mecanismos de vigilancia en los sistemas internacionales podrán conocer y fincar responsabilidad únicamente respecto a los agentes estatales, independientemente de que se trate de actos de particulares, donde los Estados pueden ser responsables por el incumpliendo de sus obligaciones internacionales y en específico por no actuar con la debida diligencia.

Desgraciadamente tal concepción ha limitado históricamente la posibilidad de encuadrar los actos de tortura bajo la responsabilidad de particulares, por lo menos en el ámbito del derecho interno, ya que las leyes de los Estados, han limitado sus figuras penales a la definición de tortura establecida en los instrumentos internacionales.

Previo a la adopción de instrumentos internacionales específicos sobre la prohibición de la tortura, el Sistema Universal adoptó en diciembre de 1975 una declaración sobre la tortura; la Declaración sobre la Protección de Todas la Personas contra la Tortura y Otros Tratos o Penas Crueles, Inhumanos y Degradantes, ${ }^{22}$ primer instrumento que contempla una definición de tortura conformada por ciertos elementos, la intencionalidad; el infligir a una persona penas o sufrimientos graves, ya sean físicos o mentales; la finalidad de

\footnotetext{
${ }^{22}$ Adoptada por la Asamblea General de Naciones Unidas el 09 de diciembre de 1975.
} 
obtener información o una confesión, castigar, o intimidar y; cometida por un funcionario público, u otra persona a instigación suya.

“... se entenderá por tortura todo acto por el cual un funcionario público, u otra persona a instigación suya, inflija intencionalmente a una persona penas o sufrimientos graves, ya sean físicos o mentales, con el fin de obtener de ella o de un tercero información o una confesión, de castigarla por un acto que haya cometido o se sospeche que ha cometido, o de intimidar a esa persona o a otras. No se considerarán tortura las penas o sufrimientos que sean consecuencia únicamente de la privación legítima de la libertad, o sean inherentes o incidentales a ésta, en la medida en que estén en consonancia con las Reglas Mínimas para el Tratamiento de los Reclusos.

2. La tortura constituye una forma agravada y deliberada de trato o pena cruel, inhumano o degradante."23

Es de observar que la Declaración es el primer instrumento que da un elemento de distinción entre la tortura y los tratos o penas crueles, inhumanos o degradantes, basado en que la primera constituye una forma agravada y deliberada de los segundos.

Más tarde, surgen los instrumentos jurídicamente vinculantes y específicos sobre tortura, la Convención contra la Tortura y Otros Tratos o Penas Crueles, Inhumanos y Degradantes $^{24}$ (en adelante Convención de la ONU) y la Convención Interamericana para Prevenir y Sancionar la Tortura ${ }^{25}$ (en adelante Convención Interamericana).

La primera define la tortura como:

“...todo acto por el cual se inflija intencionadamente a una persona dolores o sufrimientos graves, ya sean físicos o mentales, con el fin de obtener de ella o de un

\footnotetext{
${ }^{23}$ ONU, Declaración sobre la Protección de Todas la Personas contra la Tortura y Otros Tratos o Penas Crueles, Inhumanos y Degradantes, art. 1

${ }^{24}$ Adoptada por la Asamblea General de Naciones Unidas, mediante resolución 39/46, el 10 de diciembre de 1984.

${ }^{25}$ Adoptada por la Asamblea General de la Organización de los Estados Americanos OEA, en Cartagena de Indias, Colombia, el 12 de septiembre de 1985.
} 
tercero información o una confesión, de castigarla por un acto que haya cometido, o se sospeche que ha cometido, o de intimidar o coaccionar a esa persona o a otras, $o$ por cualquier razón basada en cualquier tipo de discriminación, cuando dichos dolores o sufrimientos sean infligidos por un funcionario público u otra persona en el ejercicio de funciones públicas, a instigación suya, o con su consentimiento o aquiescencia. No se considerarán torturas los dolores o sufrimientos que sean consecuencia únicamente de sanciones legítimas, o que sean inherentes o incidentales a éstas..."

Por su parte la Convención Interamericana la define en los siguientes términos:

“... se entenderá por tortura todo acto realizado intencionalmente por el cual se inflijan a una persona penas o sufrimientos físicos o mentales, con fines de investigación criminal, como medio intimidatorio, como castigo personal, como medida preventiva, como pena o con cualquier otro fin. Se entenderá también como tortura la aplicación sobre una persona de métodos tendientes a anular la personalidad de la víctima o a disminuir su capacidad física o mental, aunque no causen dolor físico o angustia psíquica.

No estarán comprendidos en el concepto de tortura las penas o sufrimientos físicos o mentales que sean únicamente consecuencia de medidas legales o inherentes a éstas, siempre que no incluyan la realización de los actos o la aplicación de los métodos a que se refiere el presente artículo."27

Como se observa, la Convención Interamericana incorpora los métodos tendientes a anular la personalidad de la víctima o a disminuir su capacidad física o mental, aunque no causen dolor físico o angustia psíquica, interpretando así como actos de tortura, aquellos

\footnotetext{
${ }^{26}$ ONU, Convención contra la Tortura y Otros Tratos o Penas Crueles, Inhumanos o Degradantes, art. 1

${ }^{27}$ OEA, Convención Interamericana para Prevenir y Sancionar la Tortura, art. 2
} 
que responden a la definición, aunque desde la perspectiva subjetiva de la víctima no se declare o reporte sufrimiento. ${ }^{28}$

Y como responsables del delito de tortura contempla:

“a. los empleados o funcionarios públicos que actuando en ese carácter ordenen, instiguen, induzcan a su comisión, lo cometan directamente o que, pudiendo impedirlo, no lo hagan.

b. las personas que a instigación de los funcionarios o empleados públicos a que se refiere el inciso a., ordenen, instiguen o induzcan a su comisión, lo cometan directamente o sean cómplices." 29

Un aspecto fundamental que diferencia la definición de ambos instrumentos es el relacionado con los efectos en la víctima, pues mientas la Convención Interamericana contempla únicamente que el acto debe infligir a la persona "penas o sufrimientos físicos o mentales", sin especificar el nivel de la afectación o gravedad, la Convención de la ONU contempla "dolores o sufrimientos graves, ya sean físicos o mentales", lo cual puede quedar en la subjetividad, anteponiendo la gravedad como requisito del dolor o sufrimiento, y por ende, un grado de mayor dificultad en los elementos probatorios.

Así también, puede observarse que la Convención de Naciones Unidas deja abierta las finalidades en la comisión del acto, basada en cualquier tipo de discriminación, mientras que la Convención Interamericana simplemente deja abierta las finalidades para poder encuadrar cualquier otra no contemplada en la definición y agrega los métodos que anulen la personalidad de la víctima o disminuyan su capacidad física o mental, aunque no causen dolor.

De ambas definiciones se desprende que los elementos que deben conjugarse para encontrarnos ante un acto de tortura serían los siguientes:

\footnotetext{
${ }^{28}$ Instituto Interamericano de Derechos Humanos, Atención integral a víctimas de tortura en procesos de litigio, Aportes psicosociales, San José, Costa Rica, 2007, p.99

${ }^{29}$ OEA, Convención Interamericana para Prevenir y Sancionar la Tortura, art. 3
} 
1. Que sea un acto intencional;

2. Que cause sufrimientos físicos o mentales, variando la gravedad según la Convención que se trate y;

3. Que exista una finalidad.

Aunado a que debe ser perpetrada por un agente estatal u otra persona bajo la instigación, consentimiento o aquiescencia del primero.

Estos elementos han sido interpretados por los Órganos Internacionales encargados de la vigilancia de los derechos humanos, ya sean los creados en virtud de los pactos del Sistema Universal, o bien los que conforman el Sistema Regional Interamericano, quienes a través de sus resoluciones o sentencias (según sea el mecanismo de que se trate), o por medio de sus observaciones en virtud de su competencia consultiva, han asentado estándares para su debida interpretación, ampliado el ámbito de protección de la prohibición de la tortura.

Por su parte, existen otros instrumentos internacionales en materia de derechos humanos que abordan la prohibición de la tortura hacia determinados sectores de población, como son la Convención sobre los Derechos del $\mathrm{Niño}^{30}$ y la Convención Interamericana para Prevenir, Sancionar y Erradicar la Violencia Contra la Mujeres, Convención de Belém do Pará, ${ }^{31}$ la primera del Sistema Universal de Protección a Derechos Humanos y la segunda del Sistema Regional Interamericano.

La primera establece la obligación de los Estados Partes de velar porque:

“a) Ningún niño sea sometido a torturas ni a otros tratos o penas crueles, inhumanos o degradantes..."

\footnotetext{
${ }^{30}$ Adoptada por la Asamblea General de Naciones Unidas, mediante resolución 44/25, del 20 de noviembre de 1989.

${ }^{31}$ Adoptada por la Asamblea General de la Organización de los Estados Americanos, en Belem do Para, Brasil, el 06 de septiembre de 1994.

${ }^{32}$ ONU, Convención sobre los Derechos del Niño, art. 37
} 
La Convención de Belém do Pará refiere que:

"Toda mujer tiene derecho al reconocimiento, goce, ejercicio y protección de todos los derechos humanos y las libertades consagradas por los instrumentos regionales e internacionales sobre derechos humanos. Estos derechos comprenden entre otros:

d. El derecho a no ser sometida a torturas." ${ }^{\prime 33}$

\section{Obligaciones asumidas por los Estados en materia de derechos humanos}

Como ya se ha mencionado, los Estados al firmar y ratificar los instrumentos internacionales en materia de derechos humanos adquieren una serie de obligaciones. Éstas pueden ser generales o específicas, dependiendo del instrumento internacional que se adopta.

Las obligaciones generales (con relación al derecho a la integridad personal y la prohibición de la tortura) se ubican en los instrumentos rectores de los Sistemas Internacionales de Protección a los Derechos Humanos, en el caso del Sistema Universal, en el Pacto Internacional de Derechos Civiles y Políticos y en el Sistema Regional en la Convención Americana sobre Derechos Humanos.

Las obligaciones específicas se sitúan en aquellos instrumentos internacionales que tienen por objeto proteger determinados derechos humanos (prohibición a la tortura) o a determinados sectores de la población (niñez, mujeres, pueblos indígenas u originarios, etc.). En materia de derechos de las mujeres, las obligaciones específicas se ubican en la Convención Interamericana para Prevenir, Sancionar y Erradicar la Violencia contra las Mujeres y la Convención para la Eliminación de todas las formas de Discriminación contra la Mujer.

\footnotetext{
${ }^{33}$ OEA, Convención Interamericana para Prevenir, Sancionar y Erradicar la Violencia Contra la Mujer, art. 4
} 
Por cuanto a la prohibición de la tortura, las obligaciones específicas se hallan en la Convención contra la Tortura y Otros Tratos o Penas Crueles, Inhumanos y Degradantes y la Convención Interamericana para Prevenir y Sancionar la Tortura.

\subsection{Obligaciones generales}

Los instrumentos generales en materia de derechos humanos que abordan el derecho a la integridad personal y la prohibición de la tortura contemplan tres tipos de obligaciones; la obligación de respeto, de garantía y de adopción de medidas de carácter interno para hacer efectivos los derechos.

En el Sistema Interamericano la obligación de respetar y garantizar los derechos se ubica en el artículo 1 de la $\mathrm{CADH}$, que a la letra dice:

"Los Estados Partes en esta Convención se comprometen a respetar los derechos y libertades reconocidos en ella y a garantizar su libre y pleno ejercicio a toda persona que esté sujeta a su jurisdicción, sin discriminación alguna por motivos de raza, color, sexo, idioma, religión, opiniones políticas o de cualquier otra índole, origen nacional o social, posición económica, nacimiento o cualquier otra condición social." ${ }^{34}$

La obligación de adoptar disposiciones de derecho interno, está establecida en artículo 2 de la $\mathrm{CADH}$.

“...los Estados Partes se comprometen a adoptar, con arreglo a sus procedimientos constitucionales y a las disposiciones de esta Convención, las medidas legislativas o de otro carácter que fueren necesarias para hacer efectivos tales derechos y libertades." 35

En el marco de la ONU, dichas obligaciones se enmarcan en el artículo 2 del Pacto Internacional de Derechos Civiles y Políticos que a la letra establece:

\footnotetext{
${ }^{34}$ OEA, Convención Americana sobre Derechos Humanos, art. 1.

${ }^{35}$ Ibídem., art. 2
} 
"Cada uno de los Estados Partes en el presente Pacto se compromete a respetar y a garantizar a todos los individuos que se encuentren en su territorio y estén sujetos a su jurisdicción los derechos reconocidos en el presente Pacto...

Cada Estado Parte se compromete a adoptar, con arreglo a sus procedimientos constitucionales y las disposiciones del presente Pacto, las medidas oportunas para dictar las disposiciones legislativas o de otro carácter que fueren necesarias para hacer efectivos los derechos reconocidos en el presente Pacto y que no estuviesen ya garantizados por disposiciones legislativas o de otro carácter." ${ }^{36}$

De esta forma, el Estado a través de sus agentes está obligado a respetar los derechos y garantizarlos, así como adoptar las medidas necesarias para hacerlos efectivos, es decir, que todas las personas bajo su jurisdicción puedan gozar en condiciones de igualdad y sin discriminación alguna de los derechos humanos establecidos por los instrumentos internacionales.

Estas obligaciones han sido ampliadas y desarrolladas a través de los Mecanismos y Organismos Internacionales de Protección a los Derechos Humanos, es decir, la Comisión y la Corte Interamericana de Derechos Humanos y el Comité de Derechos Humanos, órgano supervisor del PIDCP.

La obligación de respeto se traduce en el deber de los Estados y sus agentes de abstenerse de violar los derechos humanos.

"...En tal sentido, en toda circunstancia en la cual un órgano o funcionario del Estado o de una institución de carácter público lesione indebidamente uno de tales derechos, se está ante un supuesto de inobservancia del deber de respeto consagrado en ese artículo [Artículo 1.1 de la CADH]. ${ }^{137}$

\footnotetext{
${ }^{36} \mathrm{ONU}$, Pacto Internacional de Derechos Civiles y Políticos, art. 2

${ }^{37}$ OEA, Corte Interamericana de Derechos Humanos (ColDH), Caso Velásquez Rodríguez Vs. Honduras, Sentencia de 29 de julio de 1988, Fondo, párr. 169
} 
Por tanto, implica la abstención por parte del Estado y sus agentes de acciones $u$ omisiones que vulneren los derechos humanos, es decir, los Estados deben abstenerse de limitar su goce o interferir en el disfrute de los mismos. Esta obligación implica también el deber de los Estados de proteger los derechos humanos, por ende, deben impedir que éstos sean violados por particulares.

“... La obligación prevista en el Pacto no se limita al respeto de los Derechos Humanos, sino que los Estados Partes se han comprometido también a garantizar el goce de esos derechos por todas las personas sometidas a su jurisdicción. Este aspecto exige que los Estados Partes realicen actividades concretas para que las personas puedan disfrutar de sus derechos." 38

Por su parte, la obligación de garantía se traduce en el deber de impulsar por parte del Estado y a través de sus órganos, la posibilidad real y efectiva de que las personas que se encuentren bajo su jurisdicción, gocen, ejerzan y disfruten sus derechos y libertades reconocidas en los instrumentos internacionales. El Estado está obligado a crear las condiciones para que las personas tengan la oportunidad de satisfacer las necesidades que han sido reconocidas por los instrumentos internacionales de derechos humanos.

La obligación de garantía establecida en el artículo 1 de la CADH fue desarrollada e interpretada ampliamente por la Corte Interamericana de Derechos Humanos (en adelante ColDH) en uno de sus primeros casos contenciosos; el Caso Velásquez Rodríguez contra Honduras. De tal forma que dichos estándares jurisprudenciales han sido la base para enmarcar la responsabilidad estatal.

A este respecto, la CoIDH ha establecido que los Estados para garantizar los derechos humanos deben prevenir, investigar y sancionar las violaciones a derechos humanos, así como restablecer los derechos y reparar el daño, en el siguiente sentido:

\footnotetext{
${ }^{38} \mathrm{ONU}$, Comité de Derechos Humanos, $13^{\circ}$ periodo de sesiones, Observación General No. 3 “Artículo 2, aplicación del Pacto a nivel nacional", párr. 1
} 
"La segunda obligación de los Estados Partes es la de "garantizar" el libre y pleno ejercicio de los derechos reconocidos en la Convención a toda persona sujeta a su jurisdicción. Esta obligación implica el deber de los Estados Partes de organizar todo el aparato gubernamental y, en general, todas las estructuras a través de las cuales se manifiesta el ejercicio del poder público, de manera tal que sean capaces de asegurar jurídicamente el libre y pleno ejercicio de los derechos humanos. Como consecuencia de esta obligación los Estados deben prevenir, investigar y sancionar toda violación de los derechos reconocidos por la Convención y procurar, además, el restablecimiento, si es posible, del derecho conculcado y, en su caso, la reparación de los daños producidos por la violación de los derechos humanos..." 39

A partir del análisis de la obligación de garantía y sus implicaciones, fue que la Corte comenzó a desarrollar el concepto de "debida diligencia"^40 con la que deben actuar los Estados para garantizar los derechos humanos y no incurrir en responsabilidad internacional, estableciendo también el alcance de las obligaciones estatales respecto a actos de terceros o particulares.

"...En efecto, un hecho ilícito violatorio de los derechos humanos que inicialmente no resulte imputable directamente a un Estado, por ejemplo, por ser obra de un particular o por no haberse identificado al autor de la transgresión, puede acarrear la responsabilidad internacional del Estado, no por ese hecho en sí mismo, sino por falta de la debida diligencia para prevenir la violación o para tratarla en los términos requeridos por la Convención. "41

En el mismo sentido, el Comité de Derechos Humanos de la ONU también ha desarrollado estándares para determinar violaciones a derechos humanos por parte de particulares, estableciendo que para que un Estado cumpla positivamente su obligación de garantizar los derechos humanos, deberá proteger a las personas no sólo de las

\footnotetext{
${ }^{39}$ CoIDH, Caso Velásquez Rodríguez Vs. Honduras, op. cit., párr.166

${ }^{40}$ El deber de debida diligencia ha sido reconocido como un principio del derecho internacional de los derechos humanos, como sucede con el deber de no discriminación que también es reconocido como un principio. Para la presente investigación se hará referencia a la debida diligencia como un deber estatal, para hacer mayor énfasis en su grado vinculante

${ }^{41}$ ColDH, Caso Velásquez Rodríguez Vs. Honduras, op. cit., párr.172
} 
violaciones cometidas por sus agentes, sino también contra los actos que cometan particulares, y que:

"Puede haber circunstancias en las que, por no haberse garantizado los derechos reconocidos en el Pacto como se dispone en el artículo 2, los Estados Parte infrinjan estos derechos permitiendo que particulares o entidades cometan tales actos o no adoptando las medidas apropiadas o no ejerciendo el cuidado debido para prevenir, castigar, investigar o reparar el daño así causado." 42

De estos estándares se observa que el deber de debida diligencia se desprende de la obligación de garantía, e implica que los Estados actúen con la debida diligencia para prevenir las violaciones a derechos humanos, investigarlas, sancionar a los responsables, reparar el daño y restablecer los derechos conculcados en la medida que sea posible, es decir, colocar a las personas en la situación en que se encontraban con anterioridad a la violación de sus derechos, respecto al goce de los mismos, sin embargo, existirán derechos de imposible restablecimiento, como lo es el derecho a la vida.

En materia de violencia contra las mujeres, el concepto de debida diligencia se siguió desarrollando a través del derecho internacional de los derechos humanos, por ejemplo, en 1993 se adoptó por parte de la Asamblea General de la ONU, la Declaración sobre la Eliminación de la Violencia contra la Mujer, donde se establece que los Estados deberán proceder con la debida diligencia a fin de prevenir, investigar y castigar todo acto de violencia contra la mujer, ya sea perpetrado por el Estado o por particulares. ${ }^{43}$

En 1994, el Comité CEDAW adoptó la Recomendación General 19 sobre la violencia a la mujer, donde refiere:

"En virtud del derecho internacional y de pactos específicos de derechos humanos, los Estados también pueden ser responsables de actos privados si no adoptan

\footnotetext{
${ }^{42} \mathrm{ONU}$, Comité de Derechos Humanos, $80^{\circ}$ periodo de sesiones, Observación General No. 31, "Naturaleza de la obligación jurídica general impuesta a los Estados Partes en el Pacto", párr.8

${ }^{43} \mathrm{ONU}$, Declaración sobre la Eliminación de la Violencia contra la Mujer, art. 4c
} 
medidas con la diligencia debida para impedir la violación de los derechos o para investigar y castigar los actos de violencia e indemnizar a las víctimas. ${ }^{\prime 44}$

Más adelante en 1995, con la adopción de la Convención Interamericana para Prevenir, Sancionar y Erradicar la Violencia contra las Mujeres, se reafirma la obligación de los Estados de actuar con la debida diligencia para prevenir, investigar y sancionar la violencia contra la mujer. ${ }^{45}$

Estos últimos instrumentos se han limitado a interpretar el deber de debida diligencia a la serie de acciones estatales encaminadas a la prevención, investigación y sanción de las violaciones a derechos humanos (en ocasiones indemnización), sin embargo, retomando los primeros estándares internacionales emitidos a través de la CoIDH, se hará referencia al deber de debida diligencia, como la serie de acciones que implican la prevención, investigación, sanción, reparación del daño y restablecimiento del derecho conculcado.

Por su parte la obligación de adoptar disposiciones de derecho interno, comprende tanto las medidas legislativas como cualquier otra necesaria para hacer efectivos los derechos humanos y ponerlos al alcance de las personas, tanto en su ejercicio, como en su garantía.

En palabras de la ColDH, tal obligación comprende también la de no dictar medidas cuando éstas conduzcan a violar los derechos humanos y libertades fundamentales, es decir, no adoptar aquellas que contradigan el objeto y fin de la Convención Americana sobre Derechos Humanos. ${ }^{46}$

Cabe señalar, que la responsabilidad del Estado con respecto a sus obligaciones internacionales no recae únicamente al rango federal, por ser ahí donde se firman los tratados. El Comité de Derechos Humanos de la ONU ha establecido que:

\footnotetext{
${ }^{44}$ ONU, Comité para la Eliminación de la Discriminación contra la Mujer, Recomendación General No 19 “La violencia contra la Mujer”, párr. 9

${ }^{45}$ OEA, Convención Belém do Pará, op.cit., art. 7b.

${ }^{46} \mathrm{CoIDH}$, Opinión Consultiva OC-14/94, Responsabilidad Internacional por expedición y aplicación de leyes violatorias de la Convención (Arts. 1y 2 de la Convención Americana sobre Derechos Humanos), 09 de diciembre de 1994, solicitada por la Comisión Interamericana de Derechos Humanos, párr. 33 y36
} 
"Todos los poderes públicos (ejecutivo, legislativo y judicial) y demás autoridades públicas o gubernamentales, sea cual fuere su rango -nacional, regional o localestán en condiciones de comprometer la responsabilidad del Estado Parte. ${ }^{\prime 47}$

Obligaciones que en México se refuerzan con la reforma constitucional en materia de derechos humanos de 2011, que armoniza esta obligación internacional en su texto, estableciendo:

"Todas las autoridades, en el ámbito de sus competencias, tienen la obligación de promover, respetar, proteger y garantizar los derechos humanos de conformidad con los principios de universalidad, interdependencia, indivisibilidad y progresividad. En consecuencia, el Estado deberá prevenir, investigar, sancionar y reparar las violaciones a los derechos humanos, en los términos que establezca la ley. ${ }^{\prime 48}$

\subsection{Obligaciones específicas en materia de violencia contra las mujeres}

La Convención sobre la Eliminación de Todas las Formas de Discriminación contra la Mujer, contempla un núcleo duro de obligaciones estatales (en los artículos 2, 3, 4, 5 y 24) en materia de eliminación de la discriminación contra las mujeres, por su parte el artículo 2 señala las siguientes:

"Los Estados Partes condenan la discriminación contra la mujer en todas sus formas, convienen en seguir, por todos los medios apropiados y sin dilaciones, una política encaminada a eliminar la discriminación contra la mujer y, con tal objeto, se comprometen a:

a) Consagrar, si aún no lo han hecho, en sus constituciones nacionales y en cualquier otra legislación apropiada el principio de la igualdad del hombre y de la mujer y asegurar por ley u otros medios apropiados la realización práctica de ese principio;

\footnotetext{
${ }^{47}$ Comité de Derechos Humanos, $80^{\circ}$ periodo de sesiones, Observación General No. 31, "Naturaleza de la obligación jurídica general impuesta a los Estados Partes en el Pacto", párr. 4

${ }^{48}$ Constitución Política de los Estados Unidos Mexicanos, promulgada el 5 de febrero de 1917, última reforma publicada en el Diario Oficial de la Federación el 26 de febrero de 2013, art. 1, párr. 3
} 
b) Adoptar medidas adecuadas, legislativas y de otro carácter, con las sanciones correspondientes, que prohíban toda discriminación contra la mujer;

c) Establecer la protección jurídica de los derechos de la mujer sobre una base de igualdad con los del hombre y garantizar, por conducto de los tribunales nacionales competentes y de otras instituciones públicas, la protección efectiva de la mujer contra todo acto de discriminación;

d) Abstenerse de incurrir en todo acto o práctica de discriminación contra la mujer y velar por que las autoridades e instituciones públicas actúen de conformidad con esta obligación;

e) Tomar todas las medidas apropiadas para eliminar la discriminación contra la mujer practicada por cualesquiera personas, organizaciones o empresas;

f) Adoptar todas las medidas adecuadas, incluso de carácter legislativo, para modificar o derogar leyes, reglamentos, usos y prácticas que constituyan discriminación contra la mujer;

g) Derogar todas las disposiciones penales nacionales que constituyan discriminación contra la mujer." ${ }^{49}$

La mayor parte de las obligaciones transcritas, refieren acciones relativas a la adopción de medidas necesarias para eliminar la discriminación contra la mujer, principalmente de carácter legislativo, con excepción de la tercera que además de contemplar la protección legal de los derechos de la mujer, establece una obligación de garantía por parte de los tribunales competentes. Por su parte, el apartado d) contempla la obligación de respeto, consistente en la abstención por parte de agentes estatales de incurrir en actos o prácticas de discriminación contra la mujer.

El artículo 3 de la CEDAW refiere que los Estados deberán adoptar todas las medidas apropiadas, incluso de carácter legislativo, para asegurar el desarrollo y adelanto de las

\footnotetext{
${ }^{49}$ ONU, CEDAW, op. cit., art. 2
} 
mujeres, y garantizar el ejercicio y goce de los derechos humanos y libertades fundamentales en igualdad de condiciones con el hombre. Obligación que se vincula con la establecida en el artículo 24 del mismo instrumento, al referir el compromiso de los estados a adoptar las medidas necesarias para conseguir la plena realización de los derechos reconocidos en la Convención. ${ }^{50}$

Por su parte, el artículo 4 establece la adopción de medidas especiales de carácter temporal, ${ }^{51}$ es decir, aquellas conocidas también como acciones afirmativas o positivas, trato preferencial y los sistemas de cupos, como una estrategia para lograr la integración de la mujer en materia política, económica, etc., y con la finalidad de lograr o acelerar la igualdad sustantiva o de facto. Tales medidas tienen un carácter temporal, hasta lograr el objetivo para el cual fueron creadas.

Destaca el artículo 5 que se relaciona directamente con la prevención de las causas que dan origen a la discriminación y violencia contra las mujeres:

"Los Estados Partes tomarán todas las medidas necesarias para: modificar los patrones socioculturales de conducta de hombres y mujeres, con miras a alcanzar la eliminación de los prejuicios y las prácticas consuetudinarias y de cualquier otra índole que estén basados en la idea de la inferioridad o superioridad de cualquiera de los sexos o en funciones estereotipadas de hombres y mujeres. "152

De acuerdo al Comité para la Eliminación de la Discriminación contra la Mujer, ${ }^{53}$ tales obligaciones aunadas a la definición de discriminación (Art. 1), son el marco interpretativo general de todos los artículos sustantivos de la Convención, de los cuales se desprenden 3 obligaciones:

"En primer lugar, los Estados Partes tienen la obligación de garantizar que no haya discriminación directa ni indirecta contra la mujer en las leyes y que, en el ámbito

\footnotetext{
${ }^{50}$ Ibídem., art. 3 y 24

${ }^{51}$ Ibíd., art. 4.

${ }^{52}$ Ibíd., art. $5 a$

53 Órgano creado en virtud de la Convención (Art. 17) y encargado de la supervisión y protección de los derechos y obligaciones contempladas en la misma.
} 
público y el privado, la mujer esté protegida contra la discriminación -que puedan cometer las autoridades públicas, los jueces, las organizaciones, las empresas o los particulares - por tribunales competentes y por la existencia de sanciones y otras formas de reparación. La segunda obligación de los Estados Partes es mejorar la situación de facto de la mujer adoptando políticas y programas concretos y eficaces. En tercer lugar los Estados Partes están obligados a hacer frente a las relaciones prevalecientes entre los géneros y a la persistencia de estereotipos basados en el género que afectan a la mujer no sólo a través de actos individuales sino también porque se reflejan en las leyes y las estructuras e instituciones jurídicas y sociales." ${ }^{154}$

Aunque las obligaciones para los estados se enmarcan en las disposiciones anteriores, es importante señalar que en cada uno de los derechos contemplados en la CEDAW, se hace referencia (de modo muy general) a la obligación de eliminar la discriminación contra la mujer, por ejemplo, en la vida política y pública del país (art. 7); en la representación en el plano internacional (art. 8); en la nacionalidad (art. 9); en la educación (art. 10); en el empleo (art. 11); en la salud (art. 12); en la vida económica y social (art. 13); en el desarrollo en el ámbito rural (art. 14); en la igualdad ante la ley (art. 15) y; en los asuntos relacionados con el matrimonio y las relaciones familiares (art. 16).

La CEDAW ha sido un instrumento de vanguardia en la protección de los derechos humanos de las mujeres, sobre todo ha inspirado la creación de políticas públicas con miras a eliminar la discriminación hacia las mujeres y ha sido el antecedente para la adopción de disposiciones legislativas y medidas especiales de carácter temporal en el ámbito interno.

Por su parte, la Convención Interamericana para Prevenir, Sancionar y Erradicar la Violencia Contra la Mujer, establece obligaciones de carácter inmediato y de

\footnotetext{
${ }^{54}$ ONU, Comité para la Eliminación de Todas las Formas de Discriminación Contra la Mujer (Comité CEDAW), Recomendación General N²5, párr.6-7
} 
cumplimiento progresivo en materia del derecho de las mujeres a una vida libre de violencia. Las primeras refieren:

"Los Estados Partes condenan todas las formas de violencia contra la mujer y convienen en adoptar, por todos los medios apropiados y sin dilaciones, políticas orientadas a prevenir, sancionar y erradicar dicha violencia y en llevar a cabo lo siguiente:

a. Abstenerse de cualquier acción o práctica de violencia contra la mujer y velar por que las autoridades, sus funcionarios, personal y agentes e instituciones se comporten de conformidad con esta obligación;

b. Actuar con la debida diligencia para prevenir, investigar y sancionar la violencia contra la mujer;

c. Incluir en su legislación interna normas penales, civiles y administrativas, así como las de otra naturaleza que sean necesarias para prevenir, sancionar y erradicar la violencia contra la mujer y adoptar las medidas administrativas apropiadas que sean del caso;

d. Adoptar medidas jurídicas para conminar al agresor a abstenerse de hostigar, intimidar, amenazar, dañar o poner en peligro la vida de la mujer de cualquier forma que atente contra su integridad o perjudique su propiedad;

e. Tomar todas las medidas apropiadas, incluyendo medidas de tipo legislativo, para modificar o abolir leyes y reglamentos vigentes, o para modificar prácticas jurídicas o consuetudinarias que respalden la persistencia o la tolerancia de la violencia contra la mujer;

f. Establecer procedimientos legales justos y eficaces para la mujer que haya sido sometida a violencia, que incluyan, entre otros, medidas de protección, un juicio oportuno y el acceso efectivo a tales procedimientos; 
g. Establecer los mecanismos judiciales y administrativos necesarios para asegurar que la mujer objeto de violencia tenga acceso efectivo a resarcimiento, reparación del daño u otros medios de compensación justos y eficaces, y

h. Adoptar las disposiciones legislativas o de otra índole que sean necesarias para hacer efectiva esta Convención. ${ }^{155}$

Por su parte, las obligaciones de carácter progresivo consisten en:

"... Los Estados Partes convienen en adoptar, en forma progresiva, medidas específicas, inclusive programas para:

a. Fomentar el conocimiento y la observancia del derecho de la mujer a una vida libre de violencia, y el derecho de la mujer a que se respeten y protejan sus derechos humanos;

b. Modificar los patrones socioculturales de conducta de hombres y mujeres, incluyendo el diseño de programas de educación formales y no formales apropiados a todo nivel del proceso educativo, para contrarrestar prejuicios y costumbres y todo otro tipo de prácticas que se basen en la premisa de la inferioridad o superioridad de cualquiera de los géneros o en los papeles estereotipados para el hombre y la mujer que legitimizan o exacerban la violencia contra la mujer;

c. Fomentar la educación y capacitación del personal en la administración de justicia, policial y demás funcionarios encargados de la aplicación de la ley, así como del personal a cuyo cargo esté la aplicación de las políticas de prevención, sanción y eliminación de la violencia contra la mujer;

d. Suministrar los servicios especializados apropiados para la atención necesaria a la mujer objeto de violencia, por medio de entidades de los sectores público y privado, inclusive refugios, servicios de orientación para toda la familia, cuando sea del caso, y cuidado y custodia de los menores afectados;

\footnotetext{
${ }^{55}$ OEA, Convención Belem do Para, op. cit., art. 7
} 
e. Fomentar y apoyar programas de educación gubernamentales y del sector privado destinados a concientizar al público sobre los problemas relacionados con la violencia contra la mujer, los recursos legales y la reparación que corresponda;

f. Ofrecer a la mujer objeto de violencia acceso a programas eficaces de rehabilitación y capacitación que le permitan participar plenamente en la vida pública, privada y social;

g. Alentar a los medios de comunicación a elaborar directrices adecuadas de difusión que contribuyan a erradicar la violencia contra la mujer en todas sus formas y a realzar el respeto a la dignidad de la mujer;

h. Garantizar la investigación y recopilación de estadísticas y demás información pertinente sobre las causas, consecuencias y frecuencia de la violencia contra la mujer, con el fin de evaluar la eficacia de las medidas para prevenir, sancionar y eliminar la violencia contra la mujer y de formular y aplicar los cambios que sean necesarios, $y$

i. Promover la cooperación internacional para el intercambio de ideas y experiencias y la ejecución de programas encaminados a proteger a la mujer objeto de violencia." 156

La Convención de Belém do Pará ha sido un instrumento imprescindible para exigir a los Países el cumplimiento de sus compromisos internacionales en materia de violencia contra las mujeres, pues es de observarse que dicha Convención contempla una serie obligaciones específicas que abarcan medidas tendientes a prevenir, investigar y sancionar la violencia contra la mujeres, así como a establecer los mecanismos y procedimientos necesarios para garantizar a las mujeres el acceso a la justicia para remediar las violaciones perpetradas en su contra. Resulta fundamental que este instrumento haya contemplado el deber de debida diligencia de manera específica para garantizar el derecho de las mujeres a una vida libre de violencia.

\footnotetext{
${ }^{56}$ Ibídem., art.8
} 
En el ámbito del derecho interno, la Convención de Belém do Pará ha sido la herramienta para lograr la adopción de disposiciones legislativas que tengan por objeto garantizar el derecho de las mujeres a una vida libre de violencia, como lo fue en México la creación de la Ley General de Acceso a las Mujeres a una Vida Libre de Violencia y las leyes estatales en la materia. Pero sobre todo permitió romper con la dicotomía de lo público y lo privado, logrando comprometer la responsabilidad estatal por actos de violencia contra las mujeres cometidos por particulares, cuando no se adoptan las medidas necesarias, ni se actúa con la debida diligencia por parte de cualquier agente estatal.

Ambos instrumentos internacionales (CEDAW y BELEM DO PARA) han sido un avance indispensable para el reconocimiento de los derechos humanos de las mujeres, tanto en el ámbito internacional, como a nivel interno de los países, sobre todo por el grado vinculante que poseen. Sin embargo, su conocimiento y aplicabilidad en el ámbito del derecho interno, sigue siendo un reto para México y para los demás Estados parte, pues se requiere mayor difusión y capacitación en torno a estas Convenciones y las obligaciones que imponen.

\subsection{Obligaciones específicas en materia de prohibición de la tortura}

La Convención Interamericana para Prevenir y Sancionar la Tortura y la Convención contra la Tortura y otros Tratos o Penas Crueles, Inhumanos y Degradantes, contemplan disposiciones específicas respecto a la obligación de los Estados de prevenir, investigar, sancionar, reparar todo acto de tortura y adoptar disposiciones de derecho interno.

Ambas Convenciones exigen la armonización de sus disposiciones al ámbito interno de los Estados, estableciendo la obligación de que la comisión o tentativa de tortura sea constitutiva de delito conforme al derecho penal interno, debiendo establecer sanciones severas que tomen en cuenta la gravedad. ${ }^{57}$

\footnotetext{
${ }^{57}$ OEA, Convención Interamericana para Prevenir y Sancionar la Tortura, art. 6; ONU, Convención contra la Tortura y Otros tratos o Penas Crueles, Inhumanos o Degradantes, art. 4
} 
En materia de prevención, los Estados se encuentran obligados a tomar medidas de formación y adiestramiento sobre la prohibición de la tortura a sus agentes estatales, en específico a los agentes de policía, funcionarios públicos encargados de la custodia de personas privadas de la libertad, de los interrogatorios, detenciones o arrestos y personal médico. $^{58}$ La Convención contra la Tortura de Naciones Unidas incluye además la obligación de incluir la prohibición de la tortura en las normas o instrucciones de los agentes estatales, lo que se relaciona con la armonización jurídica interna.

Por otro lado y relacionado a la obligación de investigar las violaciones a derechos humanos, ambos instrumentos contemplan la obligación de garantizar que siempre que exista denuncia o razón fundada para creer que dentro de su jurisdicción se ha cometido un acto de tortura, procederán a investigar de forma imparcial, inmediata y de oficio. ${ }^{59}$ En este aspecto destaca que la Convención de la ONU contempla la protección a las víctimas de tortura y testigos, ante posibles represalias o intimidaciones por haber denunciado los hechos. ${ }^{60}$

Asimismo, ambas Convenciones refieren que una declaración obtenida mediante tortura, no podrá ser admitida como medio de prueba en un proceso, salvo en contra de la persona acusada de tortura y como prueba de que por ese medio obtuvo la declaración. ${ }^{61}$

Respecto a la obligación de reparar los daños, la Convención Interamericana contempla que los Estados deben incorporar en sus legislaciones, normas que garanticen una compensación adecuada para las víctimas. ${ }^{62}$ Sin embargo, la Convención de la ONU va más allá al establecer que como parte de la reparación deben incluirse los medios para su rehabilitación, en el siguiente sentido:

"Todo Estado Parte velará por que su legislación garantice a la víctima de un acto de tortura la reparación y el derecho a una indemnización justa y adecuada,

\footnotetext{
${ }^{58}$ Ibídem., art. 7 y 10

${ }^{59}$ Ibíd., art. 8 y 12

${ }^{60} \mathrm{ONU}$, Convención contra la Tortura y Otros tratos o Penas Crueles, Inhumanos o Degradantes, art. 13

${ }^{61} \mathrm{OEA}$, Convención Interamericana para Prevenir y Sancionar la Tortura, art. 10; ONU, Convención contra la Tortura y Otros tratos o Penas Crueles, Inhumanos o Degradantes, art. 15

${ }^{62}$ OEA, Convención Interamericana para Prevenir y Sancionar la Tortura, art. 9
} 
incluidos los medios para su rehabilitación lo más completa posible. En caso de muerte de la víctima como resultado de un acto de tortura, las personas a su cargo tendrán derecho a indemnización."63

Otro aspecto a destacar es la prohibición de la expulsión, devolución o extradición de una persona a otro Estado cuando haya razones fundadas para creer que estaría en peligro de ser sometida a tortura. ${ }^{64}$

Ambas Convenciones han sido sustanciales para poder encuadrar a partir de los elementos de su definición, los actos constitutivos de tortura, así como para exigir de los Estados parte el cumplimiento de sus compromisos asumidos en materia de prevención, investigación, sanción y reparación de daño por actos de tortura cometidos en su jurisdicción.

\footnotetext{
${ }^{63} \mathrm{ONU}$, Convención contra la Tortura y Otros Tratos o Penas Crueles, Inhumanos o Degradantes, art. 14

${ }^{64}$ OEA, Convención Interamericana para Prevenir y Sancionar la Tortura, art. 13, párr. 4; ONU, Convención contra la Tortura y Otros Tratos o Penas Crueles, Inhumanos o Degradantes, art. 3
} 


\section{Capítulo II}

\section{La justicia de género en los Tribunales Penales Internacionales ad hoc para Ruanda y la Ex Yugoslavia: Antecedentes que visibilizan la violencia sexual como método de tortura}

Los Tribunales Penales Internacionales de Ruanda y la Ex Yugoslavia son tribunales especiales ad hoc, creados a partir de las atrocidades cometidas durante los conflictos armados en Ruanda y en Bosnia-Herzegovina (ex Yugoslavia). Ambos fueron creados por resoluciones del Consejo de Seguridad de las Naciones Unidas, con la finalidad de enjuiciar a los presuntos responsables de graves violaciones al derecho internacional humanitario y contribuir a la restauración y mantenimiento de la paz.

El Tribunal Penal Internacional para la ex Yugoslavia fue creado mediante la resolución 827 del 25 de mayo de 1993, ante la preocupación “...por los continuos informes de violaciones generalizadas y flagrantes del derecho internacional humanitario que tiene lugar en el territorio de la Ex Yugoslavia, y especialmente en la República de BosniaHerzegovina, inclusive los informes de asesinatos en masa, de detenciones y violaciones de mujeres masivas, organizadas y sistemáticas..." 65

La competencia del Tribunal es determinada en su estatuto y comprende las violaciones graves de los Convenios de Ginebra de 1949, la violación de las leyes o uso de la guerra, el genocidio y los crímenes de lesa humanidad, ${ }^{66}$ cometidas a partir del $1^{\circ}$ de enero de 1991 .

Por su parte, el Tribunal Penal Internacional para Ruanda se creó mediante la resolución 955, del 08 de noviembre de 1994, ante la preocupación del genocidio y otras violaciones sistemáticas, generalizadas y manifiestas del derecho internacional humanitario, y enjuiciaría a "...los responsables de las violaciones cometidas en el territorio de Rwanda y a ciudadanos de Rwanda responsables de genocidio y otras violaciones de esa naturaleza

\footnotetext{
${ }^{65}$ ONU, Consejo de Seguridad, S/RES/827 (1993), aprobada por el Consejo de Seguridad en su $3217^{\circ}$ sesión celebrada el 25 de mayo de 1993, tercer párrafo

${ }^{66}$ Véase artículos 1 a 5 del Estatuto del Tribunal Penal Internacional para la Ex Yugoslavia, del 25 de mayo de 1993
} 
cometidas en el territorio de Estados vecinos entre el 1o de enero de 1994 y el 31 de diciembre de 1994..."

El Tribunal tiene competencia para conocer el delito de genocidio, crímenes de lesa humanidad y violaciones del artículo 3 común a los Convenios de Ginebra y del Protocolo Adicional II de los Convenios. ${ }^{68}$

En sentido estricto, ambos Tribunales no tienen competencia directa para conocer de violaciones a los derechos humanos, ya que su competencia se circunscribe al ámbito del derecho internacional humanitario, sin embargo, los delitos que conocen; genocidio, delitos de lesa humanidad y crímenes de guerra, resultan ser violatorios a los derechos humanos, en el marco de un ataque sistemático o generalizado. Así mismo los estatutos de los Tribunales Penales Internacionales de Ruanda y la Ex Yugoslavia recogen la violencia sexual como crimen de lesa humanidad y como crimen de guerra (arts. $3 g$ y $5 g$ sucesivamente).

A través de la jurisprudencia emitida mediante las resoluciones de ambos Tribunales ad hoc, se han generado estándares de interpretación que amplían el alcance de protección de los derechos humanos y que han sido empleados en el Derecho Internacional de los Derechos Humanos, sobre todo por los Organismos Internacionales de Protección a los Derechos Humanos, tanto a nivel universal, como regional o interamericano.

En lo referente a la protección del derecho de las mujeres a una vida libre de violencia, incluida la tortura, estos tribunales han generado estándares jurisprudenciales de suma importancia para lograr visualizar la violencia sexual contra mujeres como un mecanismo de tortura, pero sobre todo para la debida protección y penalización de tales actos. Por ello, independientemente de que su competencia no se centre al ámbito del derecho internacional de los derechos humanos, algunas de sus resoluciones serán analizadas en la

\footnotetext{
${ }^{67}$ ONU, Consejo de Seguridad, S/RES/955 (1994), Aprobada por el Consejo de Seguridad en su $3453^{\circ}$ sesión celebrada el 08 de noviembre de 1994, en: http://daccess-dds-ny.un.org/doc/UNDOC/GEN/N94/437/51/PDF/N9443751.pdf?OpenElement

${ }^{68}$ Véase artículos 1 a 4 del Estatuto del Tribunal Penal Internacional para Ruanda, del 08 de noviembre de 1994, en: http://www.icrc.org/spa/resources/documents/misc/treaty-1994-statute-tribunal-rwanda-5tdmhw.htm
} 
presente investigación ya que contienen estándares jurisprudenciales progresistas para la defensa de los casos de violencia sexual contra mujeres como mecanismo de tortura.

\section{Tribunal Penal Internacional para Ruanda}

\subsection{Caso Akayesu, No. ICTR-96-4-T \\ Sentencia de 2 de septiembre de 1998 \\ Fallo de la Sala de Primera Instancia}

La resolución dictada por el Tribunal Ad Hoc para Ruanda en el caso Akayesu resulta sustancial, ya que desarrolló preceptos trascendentales relativos a la violencia sexual (incluida la violación), la tortura y el genocidio, así como la responsabilidad penal internacional. La sentencia es un precedente esencial en materia de protección a los derechos humanos de las mujeres, al ser el primer fallo por parte de un Tribunal Penal Internacional que emplea un alto enfoque de género en su análisis y fundamentación, pero sobre todo al ser la primera sentencia internacional que determina los actos de violencia sexual como constitutivos de genocidio.

Los antecedentes ${ }^{69}$ que dan origen a la resolución del caso Akayesu tienen comienzo el 06 de abril de 1994, cuando a consecuencia de un atentado terrorista se estrelló un avión en el que se transportaban al presidente de Ruanda (Juvenal Habyarimana) y el Presidente de Burundi (Cyprien Ntaryamira). Tras la muerte de ambos Presidentes se desencadenaron una serie de matanzas generalizadas entre las dos dimensiones políticas y étnicas; las comunidades Hutu y Tutsi, donde los hutus acusaron a los tutsis del asesinato e iniciaron el genocidio de la comunidad tutsi y de los hutus partidarios de compartir el poder. Dicho conflicto inició en Kigali, extendiéndose a otras partes de Ruanda. En este contexto, Jean Paul Akayesu se desempeñaba como burgomaestre ${ }^{70}$ (alcalde) del municipio de Taba desde abril de 1993, hasta junio de 1994, siendo el responsable de mantener la ley y el orden público en la comuna.

\footnotetext{
${ }^{69}$ Resumen de los Antecedentes del Fallo en el Caso No. TPIR-96-4-T, el Fiscal contra Jean-Paul Akayesu, de fecha 02 de septiembre de 1998, Tribunal Penal Internacional para Ruanda.

${ }^{70}$ Ruanda está dividida en 11 prefecturas, cada una de ellas gobernada por un prefecto. Las prefecturas se subdividen en municipios que se encuentran bajo la autoridad de burgomaestres. En Ruanda, el burgomaestre es la figura más poderosa en la comuna.(Párrafo 2 Antecedentes)
} 
Entre los meses de abril a junio de 1994 al menos dos mil tutsis fueron asesinados en Taba en un contexto de violencia sistemática y generalizada, bajo el conocimiento y aquiescencia de Jean Paul Akayesu, ya que éste no impidió las masacres. Durante este periodo centenares de civiles (la mayoría mujeres, niños y niñas tutsis) buscaron refugio en las oficinas comunales, donde fueron retenidos por las milicias armadas locales y comunales, o por la policía, sometiéndoseles a diversos actos de violencia y asesinatos. En el caso de las mujeres, fueron sometidas también a actos de violencia sexual que a veces eran cometidos por más de una persona, aunado a las amenazas explícitas de muerte y lesiones. Las mujeres desplazadas vivían en constante temor y su integridad física y salud psicológica se encontraba deteriorada a consecuencia de la violencia sexual, las golpizas y asesinatos. Jean Paul Akayesu tenía conocimiento de los actos de violencia sexual que se estaban perpetrando y en ocasiones, se encontraba presente durante su comisión, sin embargo, facilitó y permitió la ejecución de los mismos, ya sea ordenándolos o instigando y ayudando a su comisión, sin tomar medida alguna para prevenirlos, impedirlos y castigar a los perpetradores.

\subsubsection{La violencia sexual}

Uno de los aspectos más relevantes a destacar en el caso Akayesu es la tipificación de la violencia sexual como constitutiva de genocidio y otros actos inhumanos dentro de la categoría de crímenes contra la humanidad. El Tribunal para llegar a dicha tipificación comenzó estableciendo una serie de criterios y definiciones con relación a la violación sexual.

Como parte de su análisis retomó la definición del delito de violación sexual empleada en diversas jurisdicciones nacionales, es decir, "una relación sexual no consentida, con variaciones donde se pueden incluir actos que implican la inserción de objetos y/o el uso de los orificios corporales no considerados intrínsecamente sexuales". ${ }^{71}$ De esta forma, el

\footnotetext{
${ }^{71}$ Tribunal Penal Internacional para Ruanda, Caso No. TPIR-96-4-T, el Fiscal contra Jean-Paul Akayesu, Sentencia del 02 de septiembre de 1998, Fallo de la Sala de Primera Instancia, párr. 596 (Traducción propia del texto en inglés)
} 
Tribunal equiparó el acto en que los interahamwes ${ }^{72}$ empujan una pieza de madera en los órganos sexuales de una mujer, como constitutivo de violación sexual.

Sin embargo, el Tribunal siguió avanzando en la definición de violación sexual al considerar que su elemento central no puede valerse de una descripción mecánica de objetos y partes del cuerpo. Para ello, ejemplifica como la Convención contra la Tortura y otros Tratos o Penas Crueles, Inhumanos o Degradantes no hace referencia a actos específicos de tortura en su definición. Así, el tribunal define tanto la violencia sexual como la violación sexual, en el siguiente sentido:

"El Tribunal define la violación como una invasión física de naturaleza sexual, cometida contra una persona en circunstancias coercitivas. La violencia sexual, que incluye la violación, se considera que es cualquier acto de naturaleza sexual de forma coercitiva sobre una persona. El acto de violencia sexual, lejos de limitarse a la penetración física del cuerpo humano, puede implicar actos que no consisten en penetración ni contacto físico."

En este avance de liberar la definición de violencia sexual del requisito de la penetración, es que el tribunal encuadra el desnudamiento forzado como violencia sexual, y por tanto, dentro de la categoría de "otros actos inhumanos", "atentados contra la dignidad personal" y "graves daños corporales y mentales" como constitutivos de crímenes contra la humanidad. Estándar que resulta de gran importancia, pues permitió ampliar el concepto de violencia sexual, desligándolo del contacto físico y a su vez visualizando la invasión del cuerpo de las mujeres.

Dicha concepción la establece al analizar un incidente descrito por los testigos, donde el acusado ordena desnudar a una estudiante y la obliga a hacer gimnasia desnuda frente a una multitud en el patio público de la oficina comunal.

\footnotetext{
${ }_{72}^{72}$ Organización ruandesa hutu anti-tutsi a la que se responsabiliza del origen del genocidio en Ruanda.

${ }^{73}$ Tribunal Penal Internacional para Ruanda, Caso Akayesu, op. cit., párr. 688
} 
A su vez señala que en este contexto no es necesario que las circunstancias coercitivas consten en una demostración física, ya que las amenazas, la intimidación, la extorción y otras formas de coacción que se aprovechan del miedo y la desesperación, pueden constituir coacción, y la coerción puede ser inherente a ciertas situaciones, tales como un conflicto armado o la presencia militar de las milicias Interahamwe entre las mujeres tutsis, en la oficina comunal. ${ }^{74}$ Considerando el contexto como un elemento suficiente para intimidar o amenazar a una persona, y por tanto constitutivo de coacción.

Respecto a la comisión de la violencia sexual perpetrada contra la mujeres, el tribunal concluyó que Akayesu tenía razones para saber que dichos actos se estaban cometiendo y que a su vez ayudó, instigó y facilitó su comisión al permitir que se llevaran a cabo, tanto dentro, como cerca de los locales de la mesa comunal, así como a través de sus palabras de aliento y en virtud de su autoridad, envió una señal clara de tolerancia oficial a la violencia sexual, sin la cual, dichos actos no habrían tenido lugar. ${ }^{75}$

De esta forma el Tribunal equiparó la desnudez forzada como constitutiva de violencia sexual y como un acto inhumano dentro de la categoría de delitos contra la humanidad, contemplada en el artículo 3 (i) de su Estatuto.

\subsubsection{La violación sexual como constitutiva de tortura}

El tribunal no resolvió en definitiva los casos de violencia sexual como tortura, sin embargo, si encuadró éstos como violación y otros actos inhumanos dentro de la categoría de crímenes lesa humanidad y genocidio, de acuerdo a lo establecido en los artículos 3 (g) e (i) y 2 (2) del Estatuto del Tribunal Internacional para Ruanda. Es decir, los desnudamientos forzados fueron encuadrados como otros actos inhumanos y las violaciones sexuales como violaciones, ambos dentro de la categoría de crímenes contra la humanidad, establecidos en el artículo 3(g) e (i) del Estatuto.

\footnotetext{
${ }^{74}$ Ibídem.

${ }^{75}$ Ibídem., párr. 694
} 
El tribunal determinó que Akayesu era culpable de tortura como delito contra la humanidad (Cargo 11, por el que se le acusa), pero únicamente por actos relacionados a las amenazas de muerte y a los golpes a las víctimas, con la finalidad de obtener información, más no por la comisión de actos de violencia sexual que tenían por objeto la misma finalidad; obtener confesiones. Sin embargo, esto se debió en gran parte a que el fiscal en ninguno de los cargos presentados ante el tribunal, hizo referencia a la violación sexual como tortura.

A pesar de ello, dentro del análisis del caso, el tribunal sí desarrolló estándares jurisprudenciales para equiparar la violación sexual como constitutiva de tortura, al establecer que:

"Como la tortura, la violación se utiliza para fines tales como la intimidación, la degradación, la humillación, la discriminación, castigo, control o destrucción de una persona. Como la tortura, la violación es una violación de la dignidad personal, y la violación de hecho constituye tortura, cuándo se inflige por funcionario público, $u$ otra persona en el ejercicio de funciones públicas, o haber actuado por instigación, o con consentimiento o aquiescencia suya."

Independientemente de que ambos delitos (violación y tortura) se encuentran dentro de la categoría de crímenes de lesa humanidad, la importancia de tipificar la violencia sexual como constitutiva de tortura, recae en reconocer que ésta tiene fines específicos, es decir, permite observar la comisión estratégica con que se perpetra por parte de los agentes estatales, ya sea como método de castigo, intimidación, humillación, discriminación de género, entre otros.

Otro aporte del Tribunal consistió en la interpretación que realiza respecto a los actos generalizados y sistemáticos, estableciendo que para considerar un acto dentro de un ataque generalizado o sistemático, es un prerrequisito que éste se cometa como parte de una amplia difusión o ataque sistemático y no sólo un acto de violencia al azar. ${ }^{77}$ De esta

\footnotetext{
${ }^{76}$ Ibíd., párr. 597

${ }^{77}$ Ibíd., párr. 579
} 
forma, desarrolló ambos conceptos, partiendo de que el concepto "generalizado" puede ser definido como masivo, frecuente o a gran escala, llevado a cabo colectivamente con seriedad considerable $\mathrm{y}$ dirigido contra una multiplicidad de víctimas, mientras que "sistemático" se puede definir como organizado y siguiendo un patrón regular sobre la base de una política común con importantes recursos públicos o privados, donde no es requisito que esta política deba tener una aprobación formal como política de estado. No obstante, debe haber algún tipo de plan o política preconcebidos. ${ }^{78}$

A partir de tales definiciones el Tribunal estableció que tanto la violación como los otros actos inhumanos que tuvieron lugar en o cerca de los locales de la oficina comunal, fueron cometidos como parte del ataque generalizado y sistemático contra la población civil y étnica de los tutsis, que tuvo lugar en Taba y generalmente en Ruanda, entre el 07 de abril y finales de junio de 1994.

Otro aspecto a destacar de la sentencia que no versa sobre la violación sexual como constitutiva de tortura, pero sí aporta elementos sustanciales, es el encuadre de la violación sexual como constitutiva de genocidio.

En este sentido, en cuanto a los cargos de genocidio y complicidad en el genocidio que se atribuyeron a Akayesu, resulta fundamental el análisis de género que realiza el Tribunal, analizando los actos de violencia contra las mujeres no sólo por su pertenencia a determinado grupo (tutsi), sino también a su pertenencia de género, donde la violencia se dirigió específicamente hacia ellas por ser mujeres. Haciendo referencia también a la objetivación sexual de las mujeres y a la sexualización de la violencia.

Lo anterior resulta sustancial tomando en cuenta que el género no se encuentra establecido dentro de los grupos protegidos por la figura de genocidio, ubicándose únicamente el grupo nacional, étnico, racial o religioso como tal, sin embargo, el Tribunal no deja de hacer referencia a la pertenencia de género de las mujeres,

\footnotetext{
${ }^{78}$ Ibíd., párr. 580
} 
independientemente de que finalmente encuadre el genocidio por la pertenencia al grupo étnico.

En este sentido, el Tribunal estableció que tanto la violación como la violencia sexual constituyen genocidio en la misma forma que cualquier otro acto, siempre y cuando se cometan con la intención específica de destruir, total o parcialmente, a un determinado grupo. Así, a la luz de las pruebas recabadas, determinó que dichos actos fueron cometidos exclusivamente contra las mujeres tutsis, muchas de las cuales fueron sometidas a la peor humillación pública, mutiladas y violadas varias veces, a menudo en público y por más de un agresor. Violaciones que tuvieron como resultado la destrucción física y psicológica de las mujeres tutsis, sus familiares y sus comunidades. Por tanto, el Tribunal resuelve que la violencia sexual fue parte integrante del proceso de destrucción dirigido específicamente a las mujeres tutsis y contribuyendo a su destrucción y a la destrucción del grupo tutsi en su conjunto. ${ }^{79}$

Asimismo, el Tribunal analizó la violación de mujeres tutsis como un acto sistemático, perpetrada solamente contra las mujeres tutsis, donde ellas fueron presentadas a modo de objetos sexuales y como parte de una campaña de propaganda dirigida a la movilización de los hutus contra los tutsis. Y hace referencia a la existencia de una representación sexual ${ }^{80}$ de la identidad étnica, que ilustra gráficamente que las mujeres tutsis fueron objeto de violencia sexual porque eran tutsis. ${ }^{81}$

Con lo mencionado en párrafos anteriores, podemos observar que el Tribunal adjudica la violencia sexual contra las mujeres a un proceso de destrucción del grupo de mujeres tutsis, manifestando también que "en la mayoría de los casos las violaciones a las mujeres, fueron acompañadas con la intención de matarlas." 82

\footnotetext{
${ }^{79}$ Ibíd., párr. 731

${ }^{80}$ Para dicho análisis el Tribunal se basa en los comentarios realizados tanto por Akayesu, como por los Interahamwe, al momento de la comisión de los actos de violencia sexual contra las mujeres tutsis, tales como; "no me vuelvan a preguntar a qué sabe una mujer tutsi" y "vamos a ver como es la vagina de una mujer tutsi".

${ }^{81}$ Tribunal Penal Internacional para Ruanda, Caso Akayesu, op. cit., párr. 732

${ }^{82}$ Ibíd., párr. 733
} 
Hace referencia también, a como en las sociedades patriarcales, donde la pertenencia a un grupo está determinada por la identidad del padre, durante la violación sexual, una mujer de un grupo es preñada por un hombre de otro grupo con la intención de que nazca un niño que no pertenece al grupo de la madre, obstaculizando así el nacimiento dentro de un grupo. ${ }^{83}$

En la sentencia resalta la sensibilidad y flexibilidad con que el Tribunal analiza las contradicciones encontradas entre las declaraciones de los testigos, haciendo referencia a como los eventos traumáticos vivenciados pueden generar dificultad para recordar con exactitud los detalles. Por ello, al encontrar inconsistencias en los testimonios de los testigos y las víctimas, el Tribunal consideró que éstas no son sustanciales para reducir la credibilidad de los testigos, ya que las contradicciones entre las declaraciones previas y los testimonios, pueden explicarse ante las dificultades de recordar detalles precisos varios años después de ocurridos los hechos, o bien por la experiencia traumática de los testigos, las dificultades de traducción y el hecho de que varios testigos eran analfabetas y expresaron no haber leído su declaraciones escritas. ${ }^{84}$

Por los hechos de violencia descritos y otros no mencionados por no ser referentes al tema de estudio, se declaró a Akayesu responsable de los siguientes cargos:

Cargo 1: Culpable de Genocidio.

Cargo 3: Culpable de crimen de lesa humanidad (Exterminio).

Cargo 4: Culpable de instigación directa y pública a cometer genocidio.

Cargo 5: Culpable de crimen de lesa humanidad (Homicidio Intencional).

Cargo 7: Culpable de crimen de lesa humanidad (Homicidio Intencional).

Cargo 9: Culpable de crimen de lesa humanidad (Homicidio Intencional).

Cargo 11: Culpable de crimen de lesa humanidad (Tortura).

\footnotetext{
${ }^{83}$ Ibíd., párr. 507

${ }^{84}$ Ibíd., párr. 455
} 
Cargo 13: Culpable de crimen de lesa humanidad (Violación).

Cargo 14: Culpable de crimen de lesa humanidad (Otros actos inhumanos).

\subsubsection{Análisis de los principales aportes de la sentencia}

La sentencia del caso Akayesu como ya se ha mencionado resulta un avance significativo en materia de protección a los derechos humanos de las mujeres, sobre todo el derecho a una vida libre de violencia, pues constituye la primera sentencia internacional que visualiza y condena la violencia sexual contra mujeres como una acto de genocidio y crimen de lesa humanidad, pero a su vez constitutivo de tortura.

Dicha sentencia marca un hito histórico para la visualización de la violencia sexual contra mujeres en la historia, pues con anterioridad los Tribunales Militares Internacionales para Nuremberg y Tokio no condenaron la violencia sexual de la que eran objeto las mujeres sistemáticamente durante la segunda guerra mundial, por el contrario, ésta fue tolerada y perpetrada por ambas partes del conflicto.

De igual forma, implicó un avance sustancial para la ampliación de la definición de la violencia sexual, desligándolo de la penetración y de la descripción mecánica de objetos y partes del cuerpo, aportando así elementos importantes como la invasión física de naturaleza sexual en circunstancias coercitivas, liberando la violencia sexual contra las mujeres del acto de penetración, lo que significó un avance para poder encuadrar otros actos sexuales cometidos contra las mujeres y que quedaban en el anonimato, como lo es la desnudez forzada.

En este sentido es importante reconocer que la desnudez forzada contra las mujeres que durante años fue invisibilizada y por tanto tolerada, es un mecanismo de acceso coercitivo al cuerpo de las mujeres, a su autonomía y su integridad, que violenta el mismo bien jurídico tutelado en los casos de violación sexual; la libertad sexual. Por ello es de suma importancia que la sentencia del caso Akayesu haya librado su interpretación de prejuicios de género basados en la objetivación y dominio sobre el cuerpo y la sexualidad de las 
mujeres, y se haya entonces reconocido la desnudez forzada como un delito de real importancia bajo la figura de crímenes de lesa humanidad, lo que ha dejado un precedente histórico para tipificar dichos actos en un futuro.

Otro aporte importante es el vinculado a las circunstancias coercitivas, donde el Tribunal desliga éstas de la demostración física, dicho estándar resulta de gran ayuda al ámbito de jurisdicción interna, donde en muchas de las ocasiones los operadores de justicia realizan una interpretación y aplicación de la ley permeada por sus propios prejuicios y concepciones, requiriendo en los casos de violencia sexual o violación pruebas de las resistencia opuesta por las víctimas, para justificar las circunstancias coercitivas mediante el uso de la fuerza, desconociendo así diversos factores asociados al género que colocan a las mujeres en situación de vulnerabilidad frente a la violencia, entre ellos las relaciones desiguales de poder y sus efectos sobre la víctima.

En este caso, el Tribunal genera un nexo entre las circunstancias coercitivas y la intimidación, la extorción y otras formas de coacción que se aprovechan del miedo y la desesperación, así como la existencia misma del conflicto armado o de la presencia de las milicias, con ello, puede observarse el análisis de género en la resolución del Tribunal, pues en pocas ocasiones se toma en cuenta la intimidación como medio de coacción, lo que a todas luces está presente en las relaciones desiguales de poder entre los géneros, como puede darse en las relaciones de violencia, de superioridad y de parentesco entre víctima y agresor.

Respecto a la violencia sexual como método de tortura, el Tribunal aunque no lo resolvió como tal, si emitió estándares en cuanto a su equiparación, manifestando que ésta se comete con mismos fines que la tortura, lo que resulta imprescindible para el abordaje de casos similares como constitutivos de tortura, pero sobre todo significa un avance histórico ya que la violencia sexual había sido históricamente tolerada, sobre todo en situaciones de conflicto armado, es más era considerada una estrategia de alivio para los soldados. Tal estándar jurisprudencial es una muestra más de la aplicación por parte del Tribunal de la justicia de género para resolver el asunto, pues por primera vez en la 
historia de la justicia internacional son penados los crímenes de violencia sexual contra las mujeres, dejando así en el pasado la legitimización de la misma y la ilegitima apropiación sobre el cuerpo de las mujeres.

Otro aporte que ya se ha comentado, es que el Tribunal define los conceptos de sistemático y generalizado, definición que se siguió empleando tanto por este Tribunal, como por el la ex - Yugoslavia, y que significa un gran aporte, pues de hecho el propio Estatuto de la Corte Penal Internacional de Roma, al contemplar los crímenes de lesa humanidad, no define tales conceptos.

Resulta significativo también el análisis del Tribunal de los grupos protegidos en los crímenes de genocidio (nacional, étnico, racial o religioso), pues si bien dentro de estos no se ubica el género, siendo una lista de grupos limitada, en el fallo si se hace referencia a que los ataques, es decir los actos de violencia contra las mujeres, fueron dirigidos hacia ellas no sólo por su pertenencia al grupo étnico, sino también a su pertenencia de género, independientemente de que concluya la tipificación del genocidio por la pertenencia al grupo étnico tutsi. Tal aproximación permite visualizar la violencia que es dirigida hacia las mujeres por el hecho de ser mujeres, como en su gran mayoría los son actos de violencia sexual; como una manifestación del poder que ejerce un género sobre otro, y que no tiene otra razón de ser que demostrar las relaciones desiguales de poder entre los géneros y los prejuicios de superioridad e inferioridad de los sexos.

Pero sobretodo, lo anterior me parece sustancial ya que puede dar cabida a que en un futuro y ante la codificación de la costumbre jurídica como fuente del derecho internacional, dicho estándar se transforme en norma jurídica, en pro de la defensa de los derechos humanos de las mujeres.

Aunado al análisis respecto al grupo de género, el Tribunal visualiza el encuadre de la violencia sexual contra las mujeres como un acto dirigido a la destrucción tanto del grupo étnico en su conjunto, como a la destrucción física y psicológica del grupo de mujeres. Y sobre todo interpreta el alcance de protección de los actos que consisten en impedir los 
nacimientos dentro de un grupo, encuadrando en éstos la violación sexual con la intención de que nazca un niño que no pertenezca a tal grupo, es decir, amplía el alcance de protección de dicho medio comisivo del genocidio, donde no se encuentra la violencia sexual de forma enunciativa. Lo que significa un avance en el campo del derecho, pero sobretodo un avance de género que reconoce los efectos de la violación sexual y como el acceso al cuerpo de las mujeres puede ser empleada con fines estratégicos.

Tal precedente es un avance en materia de Derecho Penal Internacional que ha sido usado constantemente por los Tribunales en casos similares.

Por último, otro aporte que se debe destacar es que en la sentencia se generan estándares para flexibilizar las declaraciones de las víctimas y los testigos debido a los efectos traumáticos de la violencia sexual o de cualquier otro acto, así como la dificultad de las víctimas de recordar con exactitud los hechos habiendo transcurrido varios años. Este aporte es de suma importancia pues los juicios por violencia sexual suelen ser muy rígidos, aunado a los prejuicios de género de los operadores de justicia, que provocan la descalificación de los testimonios de las mujeres y su re victimización al colocar sobre ellas no sólo la carga de la prueba, sino también la responsabilidad por los hechos vivenciados.

A través de la jurisprudencia emitida mediante el Tribunal, se han generado estándares de interpretación que amplían el alcance de protección de los derechos humanos de las mujeres, en específico relacionados con la violencia sexual, pues han logrado visualizarla y sancionarla a través de los enjuiciamientos de los responsables. Dichos estándares, como se observara en el siguiente capítulo, han sido empleados en el Derecho Internacional de los Derechos Humanos, como parte de la interpretación de los Organismos Internacionales de Protección a los Derechos Humanos, sobre todo a nivel regional.

Un ejemplo de lo anterior, es la Sentencia Penal Castro Castro Vs. Perú, donde la Corte Interamericana para acreditar la violencia sexual hacia las mujeres, empleó los estándares emitidos en el caso Akayesu, respecto a que "Ia violencia sexual se configura con acciones de naturaleza sexual que se cometen en una persona sin su consentimiento, que además 
de comprender la invasión física del cuerpo humano, pueden incluir actos que no involucren penetración o incluso contacto físico alguno". ${ }^{85}$ Así, la Corte dejó claro que la violencia sexual no requiere para su configuración requisitos específicos como la penetración o el contacto físico, extinguiendo la necesidad de acreditar estos elementos y estableciendo la existencia de actos de naturaleza sexual que comprenden la invasión del cuerpo, aun cuando no exista contacto físico, como la desnudez forzada.

\section{Tribunal Penal Internacional para la Ex Yugoslavia}

\subsection{Caso Funrundzija, No. IT-95-17/1-PT \\ Sentencia de 10 de diciembre de 1998 \\ Fallo de la Sala de Primera Instancia}

Los hechos que dan origen a la sentencia del caso Furundzija, se enmarcan en un contexto de conflicto armado entre las fuerzas armadas del Gobierno de la República de Bosnia y Herzegovina (que se declaró independiente en 1929) y las fuerzas armadas de la Comunidad Croata de Herzeg-Bosnia (que se consideraba una entidad política independiente ${ }^{86}$ dentro de la República de Bosnia y Herzegovina).

En este contexto, el acusado era miembro de los Jokers, una unidad especial de la policía militar de la Comunidad Croata de Herzeg-Bosna, conocida como el Consejo de Defensa de Croacia (HVO), quien estuvo involucrado en el Conflicto Armado de Bosnia y Herzegovina desde enero de 1993, hasta mediados de julio del mismo año. Durante este tiempo atacaron pueblos habitados principalmente por población Bosnia musulmán, en la región de Lava del Valle del Rio, en el centro de Bosnia y Herzegovina, incluyendo el Municipio de Vitez ${ }^{87}$ y el ataque a la Aldea Ahmii. Ataques que llevaron a la expulsión, detención, lesiones y muerte de numerosos civiles.

\footnotetext{
${ }^{85}$ Ibíd., párr. 688, citado por ColDH, Caso Penal Castro Castro Vs. Perú, Sentencia de 25 de noviembre de 2006, Fondo, Reparaciones y Costas, párr. 306

${ }^{86}$ LA Comunidad Croata de Herzeg-Bosna se había declarado una entidad política independiente dentro de la República de Bosnia y Herzegovina el 3 de julio de 1992.

${ }^{87}$ En junio de 1992 el Consejo Croata de Defensa (HVO) tomó el ayuntamiento, la estación de policía y el edificio de Defensa Territorial de Vitez, exigiendo que los musulmanes se colocaran bajo su mando, sin embargo los musulmanes consideran esta situación un golpe ilegal y se niegan a formar parte del nuevo gobierno. Posteriormente el control de la Ciudad de Vitez es tomado por el HVO y el acoso a
} 


\subsubsection{La tortura}

El Tribunal para tipificar la violencia sexual como tortura, comenzó por realizar un amplio análisis de la tortura en el Derecho Internacional Humanitario. De esta forma, observó como la tortura se encuentra expresamente prohibida tanto por el derecho internacional humanitario, como por el derecho internacional de los derechos humanos y reforzada por una norma imperativa jus cogens.

El Tribunal analiza como la prohibición de la tortura presenta tres características importantes ${ }^{88}$ en común con los demás principios generales que protegen los derechos humanos, siendo estas:

La prohibición incluso sobre posibles infracciones, donde los Estados están obligados no sólo a prohibir y sancionar la tortura, sino también a prevenir su concurrencia, están obligados a poner en marcha todas aquellas medidas dentro de su ordenamiento interno para prevenir la tortura. Es decir, las normas internacionales prohíben no sólo la comisión de la tortura, sino también la falta de adopción de medidas necesarias para su prohibición, a través de la adopción de leyes.

La prohibición impone obligaciones Erga Omnes, es decir, las obligaciones incumben a todos los miembros de la comunidad internacional, donde cada uno de éstos tiene derechos correlativos. Por tanto, la violación de estas obligaciones constituye simultáneamente una brecha en la correlatividad de derechos de todos los miembros de la comunidad internacional y da lugar a la demanda de cumplimiento por cada uno de los miembros.

La prohibición ha adquirido un carácter de jus cogens, como una de las normas más fundamentales de la comunidad internacional, la prohibición está diseñada para producir un efecto disuasorio, con un valor absoluto, del cual nadie puede apartarse. El hecho de que la tortura esté prohibida por una norma imperativa de derecho internacional, tiene

los musulmanes se hizo frecuente y las tensiones interétnicas aumentan a medida que el HVO bloquea la ciudad. En noviembre de 1992 estalló un conflicto armado entre el Consejo Croata de Defensa (HVO) Ejército de Bosnia y Herzegovina (ABiH) en Novi Travnik.

${ }_{88}$ Tribunal Penal Internacional para la Ex Yugoslavia, Caso No. IT-95-17/1-PT, el fiscal contra Funrundzija, Sentencia del 10 de diciembre de 1998, fallo de la Sala de Primera Instancia, párr. 148-156 (Traducción propia del texto en inglés) 
efecto en el ámbito inter-estatal e individual, sirviendo en el primer caso para deslegitimar a nivel internacional las medidas legislativas, administrativas o judiciales donde se autorice tal acto y a nivel individual el Estado tiene la obligación de investigar, enjuiciar y castigar a los responsables.

Una vez analizadas las características de la prohibición de la tortura, la Sala analiza la definición de la misma, partiendo de la definición de la Convención contra la Tortura y otros Tratos o Penas Crueles, Inhumanos o Degradantes del Sistema de Naciones Unidas, estableciendo que aunque la definición se limite a la Convención, debe considerarse entre otras cosas como autoridad, porque explica en detalle todos los elementos necesarios implícitos en las normas internacionales sobre la materia y coincide en gran medida con la contenida en la Declaración de las Naciones Unidas sobre tortura y en la Convención Interamericana, así como que dicha definición ha sido aplicada por el Relator Especial de las Naciones Unidas y está en consonancia con la definición sugerida por organismos internacionales, como el Tribunal Europeo de Derechos Humanos y el Comité de Derechos Humanos. Por ello, concluye que la amplia convergencia de los instrumentos internacionales mencionados y la jurisprudencia internacional, demuestra que existe una aceptación general de los principales elementos contenidos en la definición establecida en el artículo 1 으 de la Convención contra la Tortura. ${ }^{89}$

De esta forma analiza los elementos de la tortura desde un punto de vista del derecho penal internacional relativo a los conflictos armados, siendo estos:

“ I) La imposición, por acción u omisión, de los dolores o sufrimientos graves, sean físicos o mentales;

II) Que el acto u omisión debe ser intencional;

III) Debe apuntar a obtener información o una confesión, o castigar, intimidar, humillar o coaccionar a la víctima o una tercera persona, la discriminación por motivo alguno en contra de la víctima o una tercera persona;

\footnotetext{
${ }^{89}$ Ibídem., párr. 159-161
} 
IV) Debe estar vinculado a un conflicto armado y;

V) Al menos una de las personas involucradas en el proceso de tortura debe ser un funcionario público." ${ }^{\prime 90}$

Elementos a los que se agrega la humillación a la víctima, al considerar el espíritu general del derecho internacional humanitario, donde el objetivo principal del cuerpo de leyes es proteger la dignidad humana.

\subsubsection{La violación sexual como constitutiva de tortura}

Posteriormente, para encuadrar la violación sexual como tortura, el Tribunal parte de la inexistencia de una definición en el Derecho Internacional Humanitario y en el Derecho Internacional de los Derechos Humanos, a pesar de su prohibición, ubicando como referencia la definición aportada en el caso Akayesu, en el sentido de que los elementos centrales del delito de violación no pueden sujetarse a una descripción mecánica de objetos y partes del cuerpo y retoma el estándar aportado por dicho tribunal:

"Como la tortura, la violación se utiliza para fines tales como la intimidación, la degradación, la humillación, la discriminación, castigo, control o destrucción de una persona. Como la tortura, la violación es una violación de la dignidad personal, y la violación de hecho constituye tortura, cuándo se inflige por funcionario público, $u$ otra persona en el ejercicio de funciones públicas, o haber actuado por instigación, o con consentimiento o aquiescencia suya. La cámara define la violación como una invasión física de naturaleza sexual, cometida contra una persona en circunstancias coercitivas. ${ }^{\prime 91}$

Sin embargo, la Sala de Primera Instancia en el presente caso consideró que para llegar a una definición de violación era necesario buscar los principios del derecho penal comunes a los principales sistemas jurídicos del mundo, derivados de las leyes nacionales. Tras

\footnotetext{
${ }^{90}$ Ibíd., párr. 162

${ }_{91}$ Tribunal Penal Internacional para Ruanda, Caso Akayesu, op. cit., párr. 597-598, citado por Tribunal Penal Internacional para la Ex Yugoslavia, Caso Funrundzija, op. cit., párr. 176
} 
examinar las legislaciones observó como común denominador la exigencia del elemento de la fuerza, coacción, amenaza, o actuar sin el consentimiento de la víctima y la penetración sexual por la fuerza del cuerpo humano por el pene o la inserción forzada de cualquier otro objeto en la vagina o el ano, hallando discrepancia respecto a la penetración bucal, al tratarse por algunos Estados como un asalto sexual y por otros como violación. $^{92}$

Sin embargo la Sala avanzo en el encuadre de la penetración bucal como constitutivo de violación sexual, sosteniendo en primer momento que la penetración forzada por la boca a través del órgano sexual masculino es un ataque extremadamente humillante y degradante contra la dignidad humana. Y que la dignidad humana tiene por objeto proteger a los seres humanos de los atentados en contra de su dignidad personal, ya sean ataques ilegales contra el cuerpo o amenazas contra el honor, el respeto propio o la salud mental. Por último refiere que en armonía con la dignidad humana un atentado sexual tan grave como la penetración oral forzada debe ser considerado una violación.

Con tales elementos, la Sala consideró como elementos objetivos de la violación, los siguientes:

"(I) La penetración sexual, aunque sea mínima:

(A) de la vagina o el ano de la víctima por el pene del perpetrador o cualquier otro objeto utilizado por el autor, o

(B) de la boca de la víctima por el pene del perpetrador;

(II) Por la coerción o la fuerza o la amenaza de la fuerza contra la víctima o una tercera persona."

\footnotetext{
${ }^{92}$ Tribunal Penal Internacional para la Ex Yugoslavia, Caso Funrundzija, op. cit., párr. 180-182

${ }^{93}$ Ibídem., párr. 185
} 
Respecto al último requisito la Sala agrega que las amenazas pueden ser explícitas o implícitas e infundir miedo a la víctima de que ella o un tercero puedan ser sometidas a violencia, detención, coacción u opresión psicológica.

Una vez aportados los elementos de las definiciones de tortura y violación, la Sala entró al estudio de los responsables de tales actos, partiendo por distinguir la responsabilidad de quien comete el acto de tortura y de quien instiga, ayuda o es cómplice de la misma, ya que la tortura suele implicar a un gran número de personas.

En este sentido refiere que en algunos Estados que practican la tortura tienden a compartimentar o diluir la carga moral y psicológica de perpetrar la tortura, mediante la asignación a diferentes personas (la que ordena que se lleve a cabo la tortura, la que organiza todo el proceso a nivel administrativo, la que hace preguntas, quien prepara las herramientas para la ejecución, quien inflige la tortura y quien da asistencia médica para evitar la muerte del torturado, entre otras).

De ello determina que, dejando de lado tales tendencias que son incapaces de hacer frente a esas prácticas indignas y haciendo hincapié en la importancia del objeto y la finalidad de las normas internacionales, todas las personas involucradas en el acto de tortura son igualmente responsables, aunque algunos pueden ser condenados con mayor severidad que otros, dependiendo de las circunstancias. Así como que la naturaleza del crimen, las formas que toma, y la intensidad de la condena, sugieren que en caso de la tortura todos los que en cierto modo participan son igualmente responsables.

De lo anterior distingue dos tipos de responsabilidades en la comisión de la tortura:

"(I) De ser culpable de la tortura como un autor (o coautor), el acusado deberá participar en una parte integral de la tortura y participar del propósito de la tortura, que es la intención de obtener información o una confesión, de castigar o intimidar, humillar, coaccionar o discriminar en contra de la víctima o un tercero. 
(II) De ser culpable de la tortura como cómplice o encubridor, el acusado debe ayudar de alguna manera que tiene un efecto sustancial en la perpetración del delito y con conocimiento de que la tortura está teniendo lugar. ${ }^{\prime 94}$

Una vez expuestos los elementos de la tortura, la violación sexual y la responsabilidad de tales actos, la Sala con base al auto de acusación enmendado, estudia los dos cargos contra el acusado (Cargo 13 Violación de las leyes o costumbre de la guerra (Tortura) y Cargo 14 Violación de las leyes o costumbre de la guerra (Atentados contra la dignidad personal, incluyendo violación)).

El cargo 13 versa sobre un interrogatorio realizado en dos etapas por Furundzija (el acusado) y otro soldado (acusado B) a una mujer (Víctima A), la primera dentro de las instalaciones de la gran sala de la sede de comodines en Nadioci (conocido como el Bungalow) y la segunda en la despensa, en compañía de otra persona (Víctima B).

En la primera fase, el acusado estuvo presente realizando el interrogatorio, mientras la víctima A se encontraba en total desnudez, y el acusado B frotó un cuchillo entre los muslos de ella, amenazándola con cortar sus partes íntimas si no decía la verdad. Finalmente el interrogatorio culminó con la amenaza de confrontarla con otra testigo, quien confesaría las acusaciones en su contra.

La segunda fase del interrogatorio fue realizado de igual forma por el acusado, mientras que el acusado $B$ golpeaba con una porra los pies de la víctima $\mathrm{A}$ y la víctima $\mathrm{B}$. El acusado B violó por la boca, la vagina y el ano a la víctima $A$, que aún estaba desnuda, en presencia de la víctima B y una audiencia de soldados, obligándola a lamer su pene. El acusado seguía interrogándola y en la medida que se intensificaba el interrogatorio, se intensificaba la agresión sexual y la violación.

La Sala determinó que la intención del acusado y del acusado B era obtener información, cuestionando a la víctima A acerca de las actividades de los miembros de su familia y otras personas, así como su relación con los soldados de HVO y su relación con el Ejército de

\footnotetext{
${ }^{94}$ Ibíd., párr. 257
} 
Bosnia y Herzegovina $(\mathrm{ABiH})$, lo que causo graves sufrimientos físicos y mentales en la víctima $A$. En relación a la víctima $B$ al sufrir ataques físicos y verse obligada a presenciar las agresiones sexuales en contra de la víctima A, a quien conocía, le causó graves sufrimientos físicos y mentales. Por lo que concluyó que los elementos de la tortura se encontraban comprobados y conforme a sus conclusiones sobre la responsabilidad de la tortura, el acusado en virtud del interrogatorio era parte integrante de la misma como coautor. $^{95}$

Por otra parte, el cargo 14 está correlacionado con la segunda fase del interrogatorio, donde la víctima A fue violada públicamente por el acusado B y en presencia del acusado. A este respecto la Sala determinó que los elementos de la violación expuestos en párrafos anteriores, se hayan corroborados en el momento en que el acusado B penetró con su pene la boca, vagina y ano de la víctima $A$.

Con referencia al consentimiento, la Sala expone que éste se encuentra viciado por la condición de cautiverio.

La Sala concluyó que la violación se cumplió, y que las violaciones y ataques sexuales se cometieron en público, mientras los soldados veían y se reían de lo que pasaba, por lo que la víctima sufrió grave dolor físico y mental, aunado a la humillación pública, lo que equivale a atentados contra su dignidad e integridad sexual.

Respecto a la responsabilidad del acusado, independientemente de que no violó personalmente a la víctima $\mathrm{A}$, ni puede considerarse como coautor, su presencia y el interrogatorio continuo fue un aliento para el acusado $B$, que contribuyó a los actos delictivos. Por lo que la Sala consideró que con base a sus conclusiones respecto a la responsabilidad, el tipo objeto de ayudar e instigar, consistente en estimular o apoyar moralmente, tiene un efecto sustancial en la perpetración del delito y que el mens rea del delito es el conocimiento de que estos actos asisten la comisión del delito, por lo que la presencia del acusado y su interrogatorio continuo equivalen a la complicidad de los

\footnotetext{
${ }^{95}$ Ibíd., párr. 265-267
} 
crímenes cometidos, encontrado así responsable de los atentados contra la dignidad personal y la violación. ${ }^{96}$

Con tales determinaciones la sala declaró culpable a Furundzija por:

Cargo 13: Violación de las leyes o usos de la guerra (Tortura).

Cargo 14: Violación de las leyes o usos de la guerra (Atentados contra la dignidad personal, incluyendo violación).

\subsubsection{Análisis de los principales aportes de la sentencia}

Los principales aportes en la sentencia del caso Furundzija están vinculados a la interpretación de la tortura y las obligaciones que de su prohibición derivan. Así, el Tribunal concluye tres características de la tortura, la obligación de los Estados de prevenirla; la imposición de obligaciones erga omnes para toda la comunidad internacional; y su carácter ius cogens, es decir como norma imperativa, que no admite acuerdo en contrario.

Un elemento sustancial del Tribunal al analizar los elementos de la tortura conforme a la Convención de la $\mathrm{ONU}$, es el agregar en dichos elementos la humillación como un atentado a la dignidad humana. Esto permite observar un análisis que va más allá de los elementos objetivos del tipo, incorporando los efectos que el acto de tortura, y en el caso específico consumado mediante la violencia sexual, provoca en las víctimas. Pues a todas luces los efectos de la tortura varían de acuerdo a las características propias de las víctimas, y en el caso de las mujeres, suele emplearse en mayor medida la violencia sexual por razones de género, por lo que los efectos suelen ser más devastadores al dañar la integridad sexual de las mujeres, su autonomía e intimidad, y en muchos de los casos generando ostracismo público provocado por los prejuicios sociales y culturales de género que desvirtúan el "valor del ser mujer". Por ello es importante que el Tribunal haya hecho

\footnotetext{
${ }^{96}$ Ibíd., párr. 273-274
} 
alusión a un elemento consecuencial de la tortura mediante la violencia sexual, como lo es la humillación a la que se enfrentan las mujeres.

El Tribunal retoma los estándares fijados en la sentencia del caso Akayesu, con relación a la eliminación de la descripción mecánica de objetos o partes del cuerpo para acreditar la violación sexual, reafirmando la invasión física de naturaleza sexual en circunstancias coercitivas, y agrega el elemento de la amenaza de la fuerza, la cual puede ser explícita o implícita e infundir miedo a la víctima de que ella o un tercero puedan ser sometidas a violencia u opresión psicológica. Con ello el Tribunal refuerza los estándares al eliminar la prueba de la fuerza en la acreditación del tipo, reconociendo la existencia de otros factores de opresión para lograr la violación sexual, lo que como ya se comentó reconoce la violencia psicológica lograda a través de la intimidación por razones de poder y de género, que sustentan y exacerban las relaciones desiguales de poder como causa de la violencia sexual.

Asimismo, aunque no es objeto de estudio de la presente investigación destaca el estudio realizado respecto a la responsabilidad individual, al distinguir la participación en autoría, coautoría, y complicidad, determinando que todas las personas participes o involucradas son igualmente responsables, independientemente de la severidad de las penas.

Es importante también la extensión que realiza respecto a la tortura psicológica a la que es objeto una víctima por tener que presenciar las agresiones sexuales en contra de una víctima diversa, concluyendo la consumación de sufrimientos físicos y mentales. Estándar que sido utilizado en diversas ocasiones por la Corte Interamericana para acreditar como la amenaza real de sufrir tortura puede constituir tortura psicológica.

Por último, destaca la argumentación del vicio del consentimiento de la víctima derivado de la condición de cautiverio, demostrando como ciertas situaciones en que las mujeres se encuentran en situación de riesgo y vulnerabilidad pueden viciar el consentimiento de las mismas, sin que esto signifique que no se encuadre la violencia sexual de la son objeto. Con tal interpretación se puede observar que se refuerza la necesidad de la coacción, la 
fuerza o amenaza de la fuerza como elemento del tipo de violación sexual, para aquellos casos en que sin necesidad de existir tales elementos, existen situaciones de riesgo, intimidación, control, entre otros, que hacen posible la comisión de la violencia sexual.

Todos estos elementos que si bien se centran en aportar estándares jurisprudenciales para reforzar la tortura, son de suma importancia para la defensa de los derechos humanos de las mujeres, cuando en específico nos referimos a actos de violencia sexual como constitutivos de tortura, aunado a que puede observarse de las interpretaciones ya señaladas la sensibilidad de género del Tribunal para tomar en cuenta las especificidades del caso por razón de género.

\subsection{Caso Dragoljub Kunarac, Radomir Kovac y Zoran Vukovic, No. IT-96-23/1-A Sentencia de 22 de febrero de 2001 Fallo de la Sala de Primera Instancia}

En el presente juicio, el Tribunal Penal Internacional Ad hoc para la Ex Yugoslavia juzgó los crímenes sexuales contra mujeres (muchas de ellas niñas musulmanas de Bosnia) cometidos en Foca, al este de Bosnia-Herzegovina. Se juzgaron principalmente diversos actos de violencia sexual, esclavitud sexual y venta de mujeres perpetrados por Zoran Vukovic, Radomir Kovac y Dragoljub Kunarac, este último jefe de una unidad de reconocimiento del Ejército de los Serbios de Bosnia, quien fue declarado culpable tanto a título personal como en su calidad de responsable de la unidad. El Tribunal determinó la culpabilidad de los agresores por crímenes de lesa humanidad por violación, tortura, ultraje a la dignidad personal y esclavitud.

\subsubsection{La violación sexual}

El Tribunal para definir el concepto de violación sexual comenzó por analizar la definición aportada por la Sala de Primera Instancia en el caso Furundzija, así como el examen general que dicha Sala realizó de los principales sistemas jurídicos del mundo, con el fin de identificar ciertos principios básicos o denominadores comunes. 
Respecto a la definición de violación sexual aportada en el caso Furundzija, ${ }^{97}$ el Tribunal en el presente caso mencionó que aunque es adecuada a las circunstancias del caso, supone una relación más estrecha que la exigida por el derecho internacional, al afirmar que el acto de penetración sexual constituye violación sólo si va acompañada por la coacción, la fuerza o la amenaza de la fuerza contra la víctima o un tercero, sin hacer referencia a otros factores que generarían un acto de penetración sexual no consensual o no voluntaria por la víctima. Asimismo refiere que de los sistemas jurídicos no estudiados en el caso Furundzija se desprende que el principio básico subyacente común, es que la penetración sexual constituye violación si no es verdaderamente voluntaria por la víctima y que el denominador común que unifica los diversos sistemas jurídicos es un principio más amplio, que consiste en penalizar las violaciones a la autonomía sexual. ${ }^{98}$

De esta forma y a la luz de los diversos sistemas jurídicos internos, identifica un gran número de factores en que se clasifican los actos sexuales como delito de violación, mismos que pueden considerarse como pertenecientes a tres amplias categorías:

“a) El acto sexual acompañado de la fuerza o la amenaza de la fuerza a la víctima o a un tercero;

b) El acto sexual acompañado de una variedad de otras circunstancias específicas que hacen a la víctima especialmente vulnerable o incapaz de resistir al acto a través del engaño y;

c) La ausencia del consentimiento o participación voluntaria." 99

Una vez que el Tribunal determina tales categorías, concluye que los factores mencionados son cuestiones que dan lugar a que se supere la voluntad de la víctima o la

\footnotetext{
${ }^{97}$ En este sentido la Sala de Primera Instancia en el caso Furundzija consideró que no era posible discernir los elementos del delito de violación de tratados internacionales o del derecho consuetudinario, ni de los principios generales del derecho penal internacional, y analizó los factores que clasifican los actos del delito de violación en los principios del derecho penal (comunes a los principales sistemas jurídicos del mundo), concluyendo que el tipo del delito de violación es: I) la penetración sexual, aunque sea mínima, de la vagina o el ano de la víctima por el pene del perpetrador o cualquier otro objeto utilizado por el autor, o de la boca de la víctima por el pene del perpetrador; II) por la coerción o la fuerza o la amenaza de la fuerza contra la víctima o de una tercera persona.

${ }_{98}$ Tribunal Penal Internacional para la Ex Yugoslavia, Caso No. IT-96-23/1-A, el Fiscal contra Dragoljub Kunarac, Radomir Kovac y Zoran Vukovic, Sentencia del 12 de junio del 2002, párr. 438-440

${ }^{99}$ Ibídem., párr. 442
} 
sumisión de la misma al acto no voluntario y que el principio básico que regula el delito de violación en las jurisdicciones nacionales, es que las violaciones graves a la autonomía sexual se sancionen, ya que la autonomía sexual es violada dondequiera que la persona sometida no ha convenido libremente o no es participante voluntaria. Así, el Tribunal retoma la definición aportada en el caso Furundzija, pero liberándola del requisito de la coacción, fuerza o amenaza de la fuerza, al establecer que estos elementos no deben interpretarse de manera restrictiva, ya que la coacción abarca la mayor parte de la conducta que niega el consentimiento.

De esta forma alcanza la siguiente definición de la violación sexual:

“... el tipo objeto del delito de violación en el derecho internacional está constituida por la penetración sexual, aunque sea mínima de:

a) La vagina o el ano de la víctima por el pene del autor o cualquier otro objeto utilizado por el autor, o;

b) De la boca de la víctima por el pene del autor, donde la penetración se produce sin el consentimiento de la víctima. El consentimiento para este fin debe ser el consentimiento dado voluntariamente, como resultado de la libre voluntad de la víctima, valorado en el contexto de las circunstancias..."100

Otro aporte importante a destacar por el Tribunal, es el reconocimiento de los efectos de la violencia sexual, al establecer que la violación constituye uno de los peores sufrimientos que un ser humano puede infligir a otro y que dan lugar a dolores severos físicos y mentales. $^{101}$

\footnotetext{
${ }^{100}$ Ibíd., párr. 460

${ }^{101}$ Ibíd., párr. 655
} 


\subsubsection{La violación sexual como constitutiva de tortura}

Una vez alcanzada la definición de violación sexual, el Tribunal determinó la comisión de la misma como constitutiva de tortura con base a los hechos de discriminación que mediaban.

Para llegar a dicha determinación y ante la falta de precedentes relativos a la tortura en el campo del derecho internacional humanitario, realizó a modo de interpretación un análisis de los diversos instrumentos internacionales en materia de derechos humanos y en específico los relativos a la tortura, destacando que la definición de la Convención Interamericana para Prevenir y Sancionar la Tortura resulta más amplia que la contenida en la Convención contra la Tortura y otros Tratos o Penas Crueles, Inhumanos y Degradantes de las Naciones Unidas, por dos razones, la primera, que no especifica un umbral del dolor o sufrimiento para que los malos tratos puedan constituir tortura, si no que elimina cualquier necesidad de sufrimiento físico o mental si la intención del autor es anular la personalidad de la víctima o disminuir su capacidad física o mental, y la segunda, que la definición no contiene una lista exhaustiva de finalidades, sino que ofrece ejemplos y agrega "o cualquier otro fin". ${ }^{102}$

Posteriormente analiza el artículo 7 del Pacto Internacional de Derechos Civiles y Políticos, que prohíbe la tortura, haciendo referencia al Comentario General No. 7/16, del Comité de Derechos Humanos, que establece que los Estados deben garantizar la protección contra la tortura, aun cuando sean infligidas por personas sin ningún poder político.

De tal análisis el Tribunal determinó que existen tres elementos de la definición de la tortura que son indiscutibles y han sido aceptados por los Estados como derecho consuetudinario internacional, siendo los siguientes:

“i) La tortura consiste en la imposición, por acción u omisión, de dolor o sufrimientos graves, ya sean físicos o mentales.

(ii) El acto u omisión debe ser intencional.

\footnotetext{
102 Ibíd., párr. 476
} 
(iii) El acto debe ser un instrumento para otros fines, en el sentido de que la imposición del dolor debe estar dirigida a alcanzar algo."103

Y que por otro lado hay tres elementos que siguen siendo polémicos:

"(i) La lista de los motivos que se persiguen, que podrían ser considerados ilegítimos y que entran dentro del ámbito de la definición de tortura.

(ii) La necesidad, en su caso, para que el acto se haya cometido en relación con un conflicto armado.

(iii) La exigencia, en su caso, que el acto sea cometido por o bajo instigación o con el consentimiento o aquiescencia de un funcionario público u otra persona en el ejercicio de sus funciones oficiales. "104

Asimismo consideró que las siguientes finalidades se han convertido en parte del derecho consuetudinario internacional:

"a. Obtener información o una confesión;

b. Castigar, intimidar o coaccionar a la víctima o una tercera persona y;

c. La discriminación, por ningún motivo, en contra la víctima o una tercera persona." 105

Llama la atención que el Tribunal en el alcance de sus interpretaciones desliga la necesidad de que la tortura pueda ser cometida exclusivamente por un funcionario público o autoridad, en este sentido, refiere que los instrumentos del derecho internacional humanitario y el Estatuto del Tribunal observan la tortura como delito y no hacen referencia a la comisión de la tortura por parte de agentes estatales, si no como un acto condenable en sí mismo por la naturaleza del acto cometido, independientemente de su autor o el estado de la persona que lo cometió.

\footnotetext{
${ }^{103}$ Ibíd., párr. 483

${ }^{104}$ Ibíd., párr. 484

${ }^{105}$ Ibíd., párr. 485
} 
Al respecto observa que la tortura conforme al derecho internacional humanitario no incluye los mismos elementos que la definición en las normas de derechos humanos, concluyendo que la presencia de un funcionario estatal o cualquier otra persona con autoridad en el proceso de tortura, no es necesaria para que el delito sea considerado como tortura en el derecho internacional humanitario. ${ }^{106}$

Y por tanto determinó que los elementos de la tortura en virtud del derecho internacional consuetudinario (con base a los estándares emitidos en las resoluciones de los casos Furundzija, Delalic y Akayesu) son:

"I. La imposición, por acción u omisión, de los dolores o sufrimientos graves, sean físicos o mentales;

II. Que el acto u omisión debe intencional y;

III. El acto u omisión debe estar dirigido a obtener información o una confesión, o en castigar, intimidar o coaccionar a la víctima o a un tercero, o en la discriminación por motivo alguno, en contra de la víctima o de una tercera persona." 107

Es de observar que a pesar del análisis previo respecto al avance de la definición de tortura en la Convención Interamericana para Prevenir y Sancionar la Tortura, al eliminar la gravedad de los dolores o sufrimientos, la Sala de Primera Instancia retoma nuevamente el elemento de la gravedad en su definición.

Una vez expuestos los elementos de la tortura, encuadró la violación sexual como constitutiva de la misma, acreditando la finalidad de la discriminación en los actos de violencia contra las víctimas por el hecho de ser musulmanas, además de cumplirse los demás elementos exigidos. Así, el Tribunal analizó el caso en particular en que Kunarac y otros dos soldados tratan de obtener información y confesiones de una mujer (relacionada a mensajes enviados a las fuerzas musulmanas), y en su intento de

\footnotetext{
${ }^{106}$ Ibíd., párr. 496

${ }^{107}$ Ibíd., párr. 497
} 
intimidarla muestran su odio y discriminación hacia la población musulmana, posteriormente es violada por los 3 soldados. Por tales hechos Kunarac resultó culpable tanto de tortura, como de violación dentro de la categoría de delitos de lesa humanidad.

En otros casos específicos de violación sexual, el Tribunal expresó que el acusado Kunarac actuó de forma deliberada y que el único propósito de la violación fue motivado por el origen étnico musulmán de las mujeres, lo que se evidenció al manifestarles que "iban a dar a luz bebes serbios" y que debían "disfrutar de ser jodidas por un serbio". En este sentido, el Tribunal agregó que la ley no requiere que el objeto de la discriminación sea el único objetivo perseguido por el infractor, ya que basta con que forme parte de su "mens rea" (mente culpable), así como que dichos actos causen a sus víctimas dolor intenso físico y mental, y sufrimiento. ${ }^{108}$ Por tanto, la Sala resolvió que se cometió delito de tortura y violación, dentro de la categoría de delitos de lesa humanidad.

En el caso del acusado Vukovic, al violar a una mujer de 16 años, el Tribunal determinó que mediaba la discriminación, toda vez que el acusado actuó bajo el conocimiento de que la víctima se encontraba en situación de refugiada musulmana y que estaba cerca de los 16 años de edad, al expresarle que "ella tenía la suerte de tener la misma edad que su hija, de lo contrario le habría hecho cosas peores". Para justificar la existencia de la discriminación como finalidad de la tortura, el Tribunal, al momento en que la defensa argumentó que el acusado actuó tras una tendencia sexual y no por odio, resolvió que:

“... lo único que importa en este contexto es la conciencia de un ataque contra la población civil musulmana de la cual su víctima era miembro, y con el fin de la tortura tenía la intención de discriminar entre el grupo del que él era miembro y el grupo de su víctima. No hay ningún requisito en virtud del derecho internacional consuetudinaria de que la conducta debe ser únicamente perpetrada por uno de los fines prohibidos por la tortura, tal como la discriminación. El propósito prohibido sólo necesita ser parte de la motivación que hay detrás de la conducta y no tiene que ser el objetivo principal o único. La Sala de Primera Instancia no tiene duda de que era

\footnotetext{
${ }^{108}$ Ibíd., párr. 654-655
} 
por lo menos un objetivo preponderante que el acusado tenía obviamente la intención de discriminar contra el grupo del que su víctima era un miembro, es decir, los musulmanes y en contra de su víctima en particular." 109

Por tanto se encontró culpable al acusado de violación y tortura, dentro de la categoría de crímenes contra la humanidad, establecida en el artículo 5 del Estatuto del Tribunal.

Otro estándar importante que permite argumentar a favor del valor y fiabilidad del testimonio de las mujeres como prueba plena, se observa cuando a razón de las discrepancias entre las declaraciones y el testimonio de dos mujeres, el Tribunal consideró que no son tan graves para desacreditar la evidencia de la violación sexual, reconociendo así las dificultades que los supervivientes de esos acontecimientos traumáticos tienen en recordar cada detalle particular y minucias precisas, y que la existencia de discrepancias no destruye necesariamente la credibilidad de otras pruebas. ${ }^{110}$

Otros aspectos a destacar de las sentencia que si bien no versan sobre la violación sexual como método de tortura, pero sí generan estándares importantes para la protección de los derechos de las mujeres y que se relacionan con la violencia sexual, son el encuadre de la desnudez forzada como un atentado con la dignidad personal y el encuadre de la esclavitud sexual como crimen contra la humanidad.

En el primer aspecto, la Sala parte de la definición de atentados o ultrajes a la dignidad personal aportada en el caso Aleksovsky:

"Un atentado contra la dignidad personal es un acto que está animado por el desprecio de la dignidad humana de otra persona. El corolario es que el acto debe causar grave humillación o degradación de la víctima. No es necesario que el acto dañe directamente el bienestar físico o mental de la víctima. Es suficiente que el acto

\footnotetext{
${ }^{109}$ Ibíd., párr. 816

${ }^{110}$ Ibíd., párr. 679
} 
cause un sufrimiento real y duradero a la persona como consecuencia de la humillación o ridiculización." ${ }^{111}$

Como consecuencia, manifiesta estar de acuerdo en que los ultrajes a la dignidad personal son actos que causan grave humillación o degradación a la víctima, más no con que la humillación o degradación deben causar sufrimiento duradero a la víctima, resaltando que mientras la degradación o humillación sea real y grave no hay razón para que sea duradera, ya que no hay motivo para considerar que la víctima se ha recuperado o superado de los efectos del delito como una indicación de que los actos no constituyen un ultraje contra la dignidad personal.

Después de analizar otras jurisprudencias que abordan los ultrajes a la dignidad personal, el Tribunal establece que la definición consta de los siguientes elementos:

“a. Que el acusado haya cometido deliberadamente o haya participado de un acto u omisión que se considere que en general cause grave humillación, degradación o de otra manera ser un grave atentado a la dignidad humana, y;

b. El conocimiento por parte del acusado de que el acto u omisión podría tener ese efecto." 112

Una vez definido el concepto, encuadra el acto en que obligaron a varias mujeres a quitarse la ropa y bailar sobre una mesa, mientras el acusado Kovac las observaba, como ultrajes a la dignidad personal. Argumentando que para las mujeres el tener que permanecer desnudas sobre una mesa, mientras el acusado las observaba, fue una experiencia dolorosa y humillante, más por su corta edad, y que Kovac debió haber sido consiente de este hecho, pero no obstante, les ordeno bailar desnudas para él, e independientemente de que el estatuto no exige que el autor deba tener la intención de

\footnotetext{
${ }^{111}$ Tribunal Penal Internacional para la Ex Yugoslavia, Caso No IT-95-14/1-T, el Fiscal contra Aleksovski, Sentencia del 25 de junio de 1999, párr. 56, citado en Caso Dragoljub Kunarac, Radomir Kovac y Zoran Vukovic, op. cit., párr. 500

${ }^{112}$ Tribunal Penal Internacional para la Ex Yugoslavia, Caso Dragoljub Kunarac, Radomir Kovac y Zoran Vukovic, op. cit., párr. 514
} 
humillar a las víctimas, basta con que sepa que su acción u omisión pueda tener tal efecto. $^{113}$

En cuanto a la condena de la esclavitud sexual como crimen contra la humanidad y ante la inexistencia de una definición del concepto por parte del estatuto, el Tribunal analizó a partir del derecho internacional humanitario y el derecho internacional de los derechos humanos, la Convención sobre la Esclavitud de $1926,{ }^{114}$ concluyendo que la esclavitud como crimen contra la humanidad en el derecho internacional consuetudinario, consiste en el ejercicio de cualquiera o todos los atributos del derecho de propiedad, considerando que el actus reus es el ejercicio de estos atributos y el aspecto subjetivo es el ejercicio intencional de esos poderes. Y que la definición debe incluir elementos de control, propiedad, limitación, control de la autonomía, de la libertad de elección o circulación, y que a menudo resulte una ganancia para el autor, donde el consentimiento de la víctima está ausente, y en ocasiones se hace imposible o irrelevante la amenaza o el uso de la fuerza u otras formas de coacción, el miedo a la violencia, engaño o falsas promesas, el abuso de poder, la posición de vulnerabilidad de la víctimas, la detención o el cautiverio, la opresión psicológica o condiciones socio-económicas. Además la esclavitud incluye la explotación, la imposición del trabajo forzoso, servicio o mano de obra obligatoria a menudo sin remuneración y con frecuencia, aunque no necesariamente, incluyendo sufrimiento físico, sexo, prostitución y la trata de personas. ${ }^{115}$

De esta forma el Tribunal encuentra culpable a Kuranac y Kovac, de mantener en cautiverio a mujeres, donde se hacían cargo de las labores domésticas de los soldados, tenían que obedecer todas sus demandas, eran obligadas al servicio sexual cuando los soldados regresaban a la casa, a tener relaciones sexuales, eran golpeadas y amenazadas, se encontraban psicológicamente oprimidas y en constante temor, humilladas y degradadas, no tenían manera de salir y su alimentación e higiene se encontraba descuidada, argumentando que se les negó cualquier control sobre sus vidas durante su

\footnotetext{
${ }^{113}$ Ibídem., párr. 766-774

${ }^{114}$ La esclavitud es el estado o condición de un individuo sobre el cual se ejercitan los atributos del derecho de propiedad o algunos de ellos, artículo 1.1 de la Convención sobre la Esclavitud, firmada en Ginebra el 25 de septiembre de 1926

${ }^{115}$ Tribunal Penal Internacional para la Ex Yugoslavia, Caso Dragoljub Kunarac, Radomir Kovac y Zoran Vukovic, op. cit., párr. 539-542
} 
estancia y que los acusados en el ejercicio de su poder de facto de la propiedad, tenían el control completo sobre su destino y las trataban como su propiedad, ejerciendo estas facultades intencionalmente y con conocimiento. ${ }^{116}$

Como circunstancias agravantes, el Tribunal consideró el papel de líder de la organización, la influencia sustancial en los otros perpetradores, la juventud de las víctimas, los delitos cometidos en el largo periodo de tiempo prolongado, la participación de más de una víctima y más de un autor, los motivos discriminatorios de género y etnia y la comisión de los delitos contra mujeres especialmente vulnerables e indefensas; las niñas.

Finalmente, se impuso sentencia de 28 años a Kunarac, de 20 años a Kovac y 12 años a Vukovi, por los siguientes cargos:

1. Dragoljub Kunarac, declarado culpable por los siguientes cargos:

Cargo 1: Crimen de lesa humanidad (tortura).

Cargo 2: Crimen de lesa humanidad (violación).

Cargo 3: Violación de las leyes o usos de la guerra (tortura).

Cargo 4: Violación de las leyes o usos de la guerra (violación).

Cargo 9: Crimen de lesa humanidad (violación).

Cargo 10: Violación de las leyes o usos de la guerra (violación).

Cargo 11: Violación de las leyes o usos de la guerra (tortura).

Cargo 12: Violación de las leyes o usos de la guerra (violación).

Cargo 18: Crimen de lesa humanidad (esclavitud).

Cargo 19: Crimen de lesa humanidad (violación).

Cargo 20: Violación de las leyes o usos de la guerra (violación).

2. Radomir Kovac, declarado culpable por los siguientes cargos:

Cargo 22: Crimen de lesa humanidad (esclavitud).

Cargo 23: Crimen de lesa humanidad (violación).

Cargo 24: Violación de las leyes o usos de la guerra (violación).

\footnotetext{
${ }^{116}$ Ibídem., párr.716-781
} 
Cargo 25: Violación de las leyes o usos de la guerra (atentados contra la dignidad personal).

3. Zoran Vukovic, declarado culpable por los cargos siguientes:

Cargo 33: Crimen de lesa humanidad (tortura).

Cargo 34: Crimen de lesa humanidad (violación).

Cargo 35: Violación de las leyes o usos de la guerra (tortura).

Cargo 36: Violación de las leyes o usos de la guerra (violación).

\subsubsection{Análisis de los principales aportes de la sentencia}

La presente sentencia significa un precedente de real importancia en materia de justicia de género, en principio porque al analizar la violencia sexual le aporta un enfoque mucho más progresista que los dos casos anteriores, ya que el Tribunal retoma los estándares aislados de las sentencias anteriores, generando así una definición integrada por todos los elementos del tipo penal, en tres categorías, la primera la coacción, la fuerza o la amenaza de la fuerza a la víctima o un tercero; la segunda el acto sexual acompañado de un variedad de circunstancias que hacen a la víctima vulnerable o incapaz de resistir el acto; y la tercera la ausencia de consentimiento. De tal suerte, que el Tribunal con los elementos asilados generó un solo concepto de violencia sexual pudiéndose llevar acabo por cualquiera de las tres categorías y concluyendo que cualquiera de éstas supera la voluntad de la misma.

Un avance importante lo es también el alcance de interpretación que le da a la primera categoría, es específico al referir que éstos (coacción, fuerza y amenaza) no deben interpretarse restrictivamente, pues ya la coacción abarca la conducta que niega el consentimiento. Categoría que al leerse a la luz de la definición que otorga a la violación sexual resulta una evolución al desvincular el acto de penetración de los requisitos de coacción, fuerza o amenaza de la fuerza contra la víctima, pero sobretodo del requisito obsoleto e infundado de demostrar la oposición de resistencia (como requisitos 
obligatorios). Ello permite vincular y argumentar otros factores que colocan a las víctimas en situación de vulnerabilidad, como lo es el engaño, la intimidación por el cargo jerárquico o familiar del agresor y el contexto bajo el cual se cometen dichas violaciones $u$ otras circunstancias que la hagan incapaz de resistir.

Destaca también la tipificación de la violencia sexual como tortura, al establecer que la definición de tortura de la Convención Interamericana para Prevenir y Sancionar la Tortura es más amplia que la aportada por la Convención de la ONU, pues la primera elimina el umbral de dolor o sufrimiento que exige la segunda, esto permite eliminar elementos subjetivos respecto a la gravedad que en muchos de los casos complica el nivel probatorio al no dejar huellas de las lesiones provocadas.

En la misma tesitura destaca el análisis de los elementos de la tortura, donde el Tribunal excluye la necesidad de que ésta se cometa en el marco de un conflicto armado, pero sobretodo elimina la exigencia de que su comisión sea por agentes estatales o bajo la aquiescencia de éstos. Elemento que sigue siendo materia de discusiones polémicas en torno a la tortura y que a su vez ha servido de precedente a la Corte Interamericana de Derechos Humanos, o por lo menos al voto concurrente de la Jueza Cecilia Medina Quiroga, en la sentencia del caso Campo algodonero Vs. México, donde pretendía tipificar los actos en el marco de los feminicidios de las mujeres de Ciudad Juárez como constitutivos de tortura, estándares jurisprudenciales relativos a los elementos que constituyen tortura como parte de las normas jus cogens: "i) el sufrimiento o dolor severos, físicos o mentales, ya sea por acción u omisión; ii) la intencionalidad del acto y iii) la motivación o fin del acto para conseguir algo." [Y Por otra parte, tres elementos que permanecen en contienda $y$, por lo tanto, no forman parte del jus cogens]: i) la lista de motivaciones por las cuales el acto se comete; ii) la necesidad de que el acto se cometa en conexión con un conflicto armado; y iii) el requisito de que el acto sea perpetrado o sea instigado por un agente del Estado o se realice con su consentimiento o aquiescencia." ${ }^{117}$

\footnotetext{
117 Ibíd., párr. 483-484, citado por ColDH, Caso González y Otras “Campo algodonero” Vs. México, Sentencia del 16 de noviembre de 2009, Excepción preliminar, fondo, reparaciones y costas, Voto Concurrente de la Jueza Cecilia Medina Quiroga en relación con la sentencia, párr. 15
} 
Esta sentencia es también un precedente importante para la tipificación de la tortura cuya finalidad es la discriminación, toda vez que la mayor parte de los casos de tortura son probados mediante la finalidad del castigo o la obtención de confesiones, sin embargo en el presente fallo se acredita la discriminación étnica mediante los comentarios realizados por los agresores a sus víctimas, lo que puede amplia la protección de la discriminación por razones de género.

Y como ya se ha mencionado recalcan los aportes vinculados a la desnudez forzada, la esclavitud sexual y los ultrajes a la dignidad personal. 


\section{Capítulo III}

\section{La Justicia de Género en el Sistema Interamericano de Derechos Humanos}

El Sistema Interamericano de Derechos Humanos surge con la Declaración Americana de Derechos y Deberes del Hombre, en 1948, instrumento que contempla un amplio catálogo de derechos humanos civiles, políticos, económicos, sociales y culturales. En el mismo año se adoptó la Carta de la Organización de los Estados Americanos, con la cual surge formalmente el primer organismo interamericano de protección a los derechos humanos; la Comisión Interamericana de Derechos Humanos, encargada de promover la observancia y protección de los derechos humanos, sin embargo, es hasta 1959 que se crea la Comisión.

Más adelante, en 1969, se adopta la Convención Americana sobre Derechos Humanos y se crea un nuevo organismo; la Corte Interamericana de Derechos Humanos, la cual es instalada en 1979. De igual forma, la Convención contempla como órgano supervisor a la Comisión Interamericana de Derechos Humanos.

De esta forma, existen dos organismos de protección a los derechos humanos en el ámbito del sistema regional, cada uno con facultades distintas, pero ambos pueden conocer de peticiones que contengan denuncias por violaciones a los derechos humanos, sin embargo, la resolución que cada uno de ellos emita tendrá un efecto distinto, pues en el caso de la Comisión a través de sus resoluciones o informes emite recomendaciones a los Estados, mientras que la Corte es un organismo jurisdiccional que emite fallos o sentencias.

No obstante, tanto las resoluciones de la Comisión, como las sentencias de la Corte (a través de la interpretación de los derechos humanos) han generado estándares progresistas y con enfoque de género para la protección de los derechos humanos de las mujeres, ya sea ampliando el marco de protección o el alcance los mismos. En este sentido, en materia de violencia sexual contra mujeres como método de tortura, ambos 
organismos han generado estándares de protección importantes para la defensa del derecho de las mujeres a una vida libre de violencia, incluida la tortura.

Por ello, el presente capítulo tiene por objeto detectar y sistematizar las resoluciones ${ }^{118}$ de los Organismos del Sistema Interamericano, en casos de violencia sexual empleada como mecanismo de tortura, a efectos de ubicar los estándares emitidos que sirvan de precedente para la defensa de casos similares en la actualidad.

\section{Recomendaciones de la Comisión Interamericana de Derechos Humanos}

La Comisión Interamericana de Derechos Humanos como organismo encargado de promover la observancia y defensa de los derechos humanos, tiene la función de recibir y actuar respecto a las peticiones que se le presenten por denuncias o quejas por violaciones a los derechos humanos. En este proceso la Comisión determinará sobre la admisibilidad de la petición con base a los requisitos ${ }^{119}$ exigidos en la CADH y posteriormente inicia el procedimiento conforme a lo establecido en el artículo 48 de la Convención, donde requerirá información al Estado y se pondrá a disposición de las partes con la finalidad de llegar a una solución amistosa del asunto.

En caso de no llegar a una solución amistosa, la Comisión emitirá un informe que transmitirá al Estado y donde podrá formularle las recomendaciones que juzgue adecuadas, $^{120}$ existiendo el plazo de tres meses para la solución del asunto o su sometimiento a la Corte Interamericana de Derechos Humanos (por parte de la Comisión o el Estado), caso contrario, la Comisión emite de nueva cuenta un informe donde hará las recomendaciones pertinentes al Estado, fijándole un plazo para que éste tome las medidas que le competan para remediar la situación, una vez que el plazo ha vencido, la Comisión decidirá si el Estado ha tomado o no las medidas adecuadas y si hace público o no su informe. ${ }^{121}$

\footnotetext{
${ }^{118}$ El presente capítulo analizará y sistematizará las resoluciones de la Comisión Interamericana de Derechos Humanos y las Sentencias de la Corte Interamericana de Derechos Humanos emitidas hasta diciembre de 2013.

${ }^{119}$ OEA, Convención Americana sobre Derechos Humanos, Art. 46 y 47

${ }^{120}$ Ibídem., Art. 50

${ }^{121}$ Ibíd., Art. 51
} 
Es a través de tales informes que la Comisión analiza el fondo del asunto y donde pueden ubicarse estándares que amplían el ámbito de protección de los derechos. Sin embargo, como se observará de los informes detectados y sistematizados (por hechos de violencia sexual como tortura), la Comisión ha evolucionado en el marco de sus interpretaciones jurídicas con perspectiva de género, pues en los primeros casos que resolvió era poca, o más bien nula, la inclusión del enfoque de género en su análisis, pero sobretodo no equiparaba los actos de violencia sexual como constitutivos de tortura.

\subsection{Caso Rosa Marta Cerna Alfaro Vs. El Salvador Informe de Fondo 10/92, del 04 de febrero de 1992}

Los hechos del caso sucedieron el 13 de enero de 1988, en Apopa, El Salvador. La denuncia fue presentada a la Comisión Interamericana en octubre de 1988. La Comisión en el curso de su 79 periodo de sesiones adoptó el informe 19/91, que se remitió al Gobierno para que realizara sus observaciones en el término de 3 meses, así también, se le realizó una serie de recomendaciones, entre estas; que solucionara el caso o lo presentara a la Corte, caso contrario se haría público el informe.

\subsubsection{Resumen de los hechos}

Rosa Marta Cerna Alfaro, de 38 años de edad fue capturada el 13 de enero de 1988 en su domicilio en Cantón tres ceibas, jurisdicción de Apopa, El Salvador, y fue llevada rumbo al monte (junto con Ismael Hernández Flores, ex reo político, quien también fue capturado) por soldados uniformados del Batallón Atlacatl, donde los interrogaron con relación a dos maletines con medicinas. Fueron trasladados a la Primera Brigada para rendir

declaraciones y en el camino llegaron a un lugar llamado La Ponderosa, donde los subieron a una pick -up para ser trasladados a la Comandancia de Apopa, les vendaron los ojos y fueron llevados al Cuartel San Carlos, donde les dijeron que les habían decomisado las dos maletas, lo que Rosa desmintió. Al otro día Rosa fue llevada a declarar, la interrogaron preguntándole si era cierto que trabajaba con la guerrilla y si conocía a unos sujetos, para lo cual le mencionaron nombres, a lo que ella les dijo que no. 
El día jueves comenzó el interrogatorio con mayor coerción, donde le ordenaron que se despojara de su ropa, dejándola desnuda y el interrogador comenzó a tocarla. El mismo día por la noche entró un soldado uniformado, quien abusó sexualmente de ella. Posteriormente fue sometida a tortura físicas, permaneciendo día y noche con los ojos vendados, con la luz eléctrica y aire acondicionado todo el tiempo. El lunes 18 a las 12 horas fue puesta en libertad y entregada a miembros de la Comisión de Derechos Humanos gubernamental.

\subsubsection{Resolución de la Comisión}

En el presente caso, la Comisión no realizó un análisis profundo sobre los hechos como constitutivos de tortura, principalmente en lo referente al desnudamiento forzado, a la violencia y violación sexual en contra de Rosa.

La Comisión se enfocó en la práctica de la detención (por un lapso mayor al que autoriza la ley, es decir 72 horas) fuera de las formalidades legales y constitucionales, donde se procedió a la realización de interrogatorios acompañados de malos tratos físicos y psicológicos, que conducen a confesiones extrajudiciales durante la detención. ${ }^{122}$

El único momento en que la $\mathrm{CIDH}$ se posiciona con relación a los hechos constitutivos de tortura, es al referirse a la respuesta del Gobierno de El Salvador, donde en el considerando número 7, expone:

"Que pese al tiempo transcurrido y a las gestiones efectuadas por la Comisión, el Gobierno de El Salvador no ha proporcionado una respuesta satisfactoria relativa a los hechos objeto del presente caso. En efecto, el contenido de la nota enviada a través de la Comisión de Derechos Humanos (gubernamental), admite el hecho de las detenciones, pero no se refiere, ni desvirtúa en modo alguno, las graves afirmaciones respecto a las torturas y otros tratos crueles, inhumanos y degradantes de que fueran

\footnotetext{
${ }^{122}$ Comisión Interamericana de Derechos Humanos (CIDH), Caso Rosa Marta Cerna Alfaro Vs El Salvador, Informe Anual 1991, Informe $\mathrm{N}^{\circ}$ 10/92, Caso 10.257, 04 de febrero de 1992, Considerando, párr. 5 y 6
} 
víctimas los señores Cerna y Hernández; ni justifica el amplio lapso durante el cual permanecieron detenidos." 123

Como se observa, la Comisión en un principio hace referencia a los hechos como malos tratos físicos y psicológicos (segundo párrafo de la resolución), pero más adelante (tercer párrafo) se refiere a éstos como constitutivos de tortura, sin mencionar de forma específica a que hechos se refiere y sobre todo si contempla o no la violencia sexual ejercida en contra de Rosa como constitutiva de tortura.

La Comisión determinó que el Gobierno de El Salvador fue responsable de la violación de los artículos 5 (integridad personal) y 7 (libertad personal) de la CADH, respecto a los hechos en contra de Rosa Marta Cerna Alfaro.

Así también, decide publicar el informe en el Informe Anual, debido a la falta de información del gobierno de El Salvador respecto de la adopción de medidas referentes al informe 19/91 y recomienda que se investiguen los hechos denunciados a fin de identificar y sancionar a los responsables, que se adopten medidas necesarias para evitar la comisión de hechos similares y que se pague una justa indemnización compensatoria a las víctimas.

\subsubsection{Análisis de los principales aportes de la resolución}

Como se observa en el presente caso, la Comisión no entra al estudio de fondo de la tortura y de la violación sexual, en un primer momento se refiere a ésta como malos tratos y en segunda instancia menciona tortura, sin embargo al realizar su determinación de responsabilidad sólo refiere la violación al artículo 5 respecto a la integridad personal, más en ningún momento analiza los elementos constitutivos de la tortura, como lo hará en años posteriores.

Esta falta de claridad en el análisis puede deberse a la época en que se resolvió el presente caso, es decir 1992, pues como veremos, en resoluciones de años posteriores, como en 1996, con el caso Raquel Martín de Mejía, la Comisión profundiza en mayor

\footnotetext{
${ }^{123}$ Ibídem., Considerando, párr. 7
} 
medida en estos aspectos. Por ende en el presente caso no puede hablarse de un enfoque de género en la resolución.

\subsection{Caso Flor de María Hernández Rivas Vs. El Salvador Informe de Fondo 7/94, Caso 10.911, del 01 de febrero de 1994}

Los hechos violatorios sucedieron el 30 de marzo de 1990. La denuncia se presentó a la Comisión el 25 de junio de 1991, quien el 05 de octubre de 1993 aprobó el informe No. 19/93 en su 84 periodo ordinario de sesiones, donde realizó una serie de recomendaciones al Estado, dándole un plazo de tres meses para que informara sobre las medidas adoptadas para el cumplimiento de las mismas.

Sin embargo, el Gobierno de El Salvador no proporcionó información alguna, por lo que la Comisión aprobó el informe de fondo 7/94 con fecha de 01 de febrero de 1994 y decide hacerlo público con base al artículo 50 de la $\mathrm{CADH}$, así también invita a El Salvador a que acepte la competencia contenciosa de la Corte en el caso específico.

\subsubsection{Resumen de los hechos}

Flor de María Hernández Rivas, de 14 años de edad, fue capturada violentamente sin orden de captura el 30 de marzo de 1990, por efectivos de la guardia nacional, quienes la obligaron a subir a una patrulla, amenazándola de muerte y acusándola de haber participado en la ofensiva del "FMLN" (Frente Farabundo Martí para la Liberación Nacional).

Flor de María fue llevada al Cuartel Central de la Guardia Nacional, donde le vendaron los ojos, la encapucharon, maltrataron sus senos y le dieron golpes en la cabeza a fin de que colaborara con ellos. Ante la negativa de aceptar los cargos que le imputaban le dieron choques eléctricos en el pecho.

El 31 de marzo fue trasladada a un cuarto pequeño y helado, donde escuchaba los gritos de otras personas que eran torturadas y no recibió alimentación. El 01 de abril la sacaron de la 
celda y fue maltratada física y verbalmente, fue llevada a otro cuarto, donde tres hombres la violaron sexualmente. El 02 de abril la devolvieron a su celda y le dieron drogas para aliviar el dolor, las cuales no tomó por temor, más tarde le quitaron la venda de los ojos, le dieron su ropa y la pusieron en libertad, amenazándola de muerte si la volvían a capturar.

\subsubsection{Resolución de la Comisión}

La Comisión en sus conclusiones respecto al fondo de la denuncia refiere la falta de información satisfactoria por parte del gobierno, pese a haber transcurrido más de 3 meses de ocurrida la detención y los malos tratos. ${ }^{124}$ Así también, determinó que el caso por la naturaleza de los hechos no es susceptible de solución amistosa, por lo que emite sus conclusiones y recomendaciones, declarando que El Salvador es responsable de los hechos denunciados, relativos a la captura en forma violenta de Flor María por efectivos de la Guardia Nacional, la acusación de participar en la ofensiva del FMLN, el haber sido sometida (sin la más mínima garantía judicial, ni consideración a su calidad de menor de edad) a malos tratos físicos y psicológicos mientras se encontraba detenida y las amenazas de muerte en su liberación.

Por lo anterior declara que El Salvador incurrió en la violación de los artículos 5 (integridad personal), 7 (libertad personal), 8 (garantías judiciales), 19 (derechos del niño) y 25 (protección judicial), en conexión con el artículo 1.1 (obligación de respetar y garantizar los derechos) de la CADH.

\subsubsection{Análisis de los principales aportes de la resolución}

Como se desprende de las conclusiones de la Comisión, ésta en ningún momento profundiza en los actos de violencia sexual, incluida la violación sexual tumultuaria en contra de Flor María, tampoco hace referencia a los actos como constitutivos de tortura, ni siquiera en los relativos a la violencia física, como lo fue la descarga eléctrica.

\footnotetext{
${ }^{124} \mathrm{CIDH}$, Caso Flor de María Hernández Rivas Vs. El Salvador, Consideraciones, apartado 3; conclusiones respecto al contenido de la denuncia, inciso a, b y c.
} 
La Comisión únicamente se refiere a los actos como constitutivos de malos tratos físicos y psicológicos, aun teniendo mayores elementos para analizar la tortura en el presente caso, dado a la condición de detención arbitraria y la minoría de edad que supone una protección especial por parte del Estado, aunado a la protección especial por encontrarse bajo custodia de agentes estatales.

Nuevamente el presente caso no realiza un análisis género sensitivo en su resolución a pesar de tener elementos para acreditar la violación sexual como constitutiva de tortura, dadas las circunstancias del caso; detención arbitraria; malos tratos; amenazas; minoría de edad y la finalidad de obtener una confesión de su participación FMLN.

Nuevamente al determinar la responsabilidad únicamente hace mención a la violación del artículo 5 de la CADH en cuanto a la integridad personal.

\subsection{Caso Comadres Vs El Salvador Informe de admisibilidad y fondo 13/96, Caso 10.948, del 01 de marzo de 1996}

Los hechos del caso se dieron durante el periodo de 1980 a 1989. La petición se presentó el 1 de junio de 1991, y el 16 de febrero de 1995 la Comisión se puso a disposición de las partes para buscar una solución amistosa. Entre 1991 y 1995 la Comisión solicitó en varias ocasiones información al gobierno de El Salvador, sin obtener respuesta. La etapa de solución amistosa se agotó sin que las partes llegaran a un acuerdo.

El gobierno de El Salvador no presentó información alguna sobre los hechos materia de la queja y tampoco dio contestación a la demanda interpuesta, por lo que la Comisión declaró el informe 13/96, transmitiéndose al Estado y dándosele el plazo de noventa días para el cumplimiento de las recomendaciones. Sin embargo, el Estado no presentó información sobre la adopción de medidas para dar cumplimiento a las recomendaciones, por lo que la Comisión en su $91^{\circ}$ Período Ordinario de Sesiones decidió adoptar el informe y publicarlo en su Informe Anual de acuerdo al artículo 51 de la CADH. 


\subsubsection{Resumen de los hechos}

Las violaciones a derechos humanos hacen referencia a una serie de ataques y hostigamientos por parte del Gobierno a la organización no gubernamental COMADRES y a varias personas vinculadas con esta, durante el periodo de 1980 a 1989.

Entre dichos ataques se hace referencia al asesinato de Ana Delmi González, que presentó signos de tortura y violación en su cuerpo (hecho No. 1 en la demanda) y el secuestro y tortura (incluida la violación por tres hombres) de María Teresa Tula, quien fue interrogada sobre sus actividades en COMADRES (hecho No. 6 en la demanda).

Se hará referencia únicamente a estos hechos por tratarse de actos violación sexual, sin embargo cabe destacar que los hechos del caso también refieren detenciones, secuestros y actos de tortura a diversas integrantes de COMADRES, así como una serie de atentados en la sede de la organización, donde se sustrae información, se estallan dos bombas y se destruyen las oficinas con explosivos, habiendo personas heridas.

\subsubsection{Resolución de la Comisión}

La Comisión comienza por analizar las obligaciones asumidas por el Estado en cuanto al respeto y garantía de los derechos humanos (establecidas en el artículo 1.1 de la CADH), para ello emplea estándares jurisprudenciales emitidos en el caso Velásquez Rodríguez Vs Honduras, respecto al alcance de dichas obligaciones.

Respecto al primer hecho, es decir la muerte de Ana Delmi González, quien presentó signos de tortura y violación en su cuerpo, la Comisión determinó que no existe suficiente especificidad en la versión aportada por los peticionarios, pues no se mencionan datos específicos. Y estableció que para presumir la veracidad de los hechos y la responsabilidad estatal, es requisito indispensable contar con una versión detallada que permita realizar un análisis de "otros elementos". 125

\footnotetext{
${ }^{125} \mathrm{CIDH}$, Caso Comadres Vs El Salvador, Informe de admisibilidad y fondo 13/96, Caso 10.948, 01 de marzo de 1996, párr. 24.1
} 
En el hecho 6 de la demanda, relacionado con el secuestro y tortura de María Teresa Tula, la Comisión lo presume como verdadero y considera que se violaron los derechos a la integridad personal (art. 5) y la libertad personal (art. 7). Esto lo determina tras ser confirmados los hechos en tres pruebas, el escrito principal; los sendos avisos publicados por COMADRES y por la Comisión de Derechos Humanos de El Salvador (no gubernamental); y el documento que relata detalladamente los hechos "affidavit" y que suscribe la víctima. ${ }^{126}$

Por tanto determina la responsabilidad del gobierno de El Salvador, por la violación al artículo 5 (integridad personal) y 7 (libertad personal), con relación a los hechos cometidos en contra de María Teresa Tula.

\subsubsection{Análisis de los principales aportes de la resolución}

En el presente caso, la Comisión determina únicamente la violación a la integridad personal y no hace referencia o profundiza en el análisis de la tortura y la violación sexual que se ejecutó en contra de María Teresa por tres hombres, a pesar de que en los hechos alegados por los peticionarios, se refiere que María Teresa fue llevada a un lugar desconocido, torturada durante tres días, cortada con arma punzo cortante, golpeada y violada por tres hombres que la interrogaron sobres sus actividades en COMADRES.

Es decir, la Comisión da por probados los hechos, por lo que pudo haber ampliado su análisis tomando en cuenta que dichos actos se ejecutaron con la finalidad de obtener de María una confesión o información sobre sus actividades en la Organización y que obviamente causaron sufrimiento físico y emocional a la víctima, lo cual la Comisión acredita indirectamente al determinar la violación a la integridad personal. En cuanto a la intencionalidad, ésta se relacionaría con la voluntad de los agentes estatales en la perpetración de los actos, con la intención de generar un daño y obtener una finalidad de esto; la información o confesión de la víctima.

\footnotetext{
${ }^{126}$ Ibídem., párr. 24.6
} 
Haber ampliado el análisis pudo haber permitido a la Comisión tipificar la violación sexual como tortura. Sin embargo, sólo refiere la violación a la integridad personal, señalando el artículo 5 en general, sin puntear alguno de sus numerales, a diferencia del hecho No. 13 de la denuncia que se relaciona con la explosión de bombas, donde la Comisión si hace referencia a la violación del artículo 5.2 encuadrándolo a tratos crueles, inhumanos o degradantes.

Nuevamente nos encontramos ante una resolución que no entra de forma detallada al estudio de la violación sexual, ni de la tortura.

Por último es importante mencionar que para la fecha en que se emitió la presente resolución (01 de marzo de 1996) ya había entrado en vigor la Convención Interamericana para Prevenir, Sancionar y Erradicar la Violencia contra la Mujer, la cual entró en vigor el 03 de mayo de 1995 y El Salvador la ratificó el 13 de noviembre de 1995, sin embargo la Comisión no hace uso de la misma a pesar de tratarse de un asunto de violencia contra las mujeres. Lo que permite observar la falta de acogimiento por parte del Sistema Interamericano del instrumento internacional de protección al derecho de las mujeres a una vida libre de violencia.

\subsection{Caso Raquel Martín de Mejía Vs Perú Informe de admisibilidad y fondo 5/96, Caso 10.970, del 01 de marzo de 1996}

Los hechos del presente caso sucedieron en 1989. En octubre del 1991 se presentó la petición ante la Comisión Interamericana de Derechos Humanos, quien resolvió el 01 de marzo de 1996 el informe de admisibilidad y fondo No. 5/96, realizando una serie de recomendaciones al Estado, así también hizo público el informe. Lamentablemente el caso no se remitió a la Corte Interamericana de Derechos Humanos. 


\subsubsection{Resumen de los hechos}

El 15 de junio de 1989 un grupo de personas con pasamontañas y ametralladoras irrumpieron en la casa de los Mejía reclamando ver al Dr. Mejía Egocheaga, al abrir la puerta, seis personas con uniformes militares entraron, uno de ellos golpeó a Dr. Mejía con el arma y lo subieron a una camioneta propiedad del gobierno. Estos hechos fueron presenciados por su esposa, la Sra. Raquel Martín Mejía.

Aproximadamente 15 minutos después de los hechos, un grupo entre seis y diez militares con pasamontañas se presentaron nuevamente a la casa, uno de ellos, quien estaba al mando del operativo, ingresó a la casa presuntamente con el objeto de solicitar a la Sra. Raquel Martín los documentos de identidad del esposo, mientras ella los buscaba, él la siguió al cuarto diciéndole que ella también se consideraba subversiva, le mostró una lista que contenía varios nombres, indicándole que eran miembros del Movimiento Revolucionario Tupac Amaru (MRTA). Raquel trató de explicarle que ni ella ni su esposo pertenecían a ningún movimiento subversivo, y finalmente la violó y se marchó.

Aproximadamente 20 minutos después, la persona regresó a la casa de los Mejía para supuestamente dar una comunicación a Raquel, la arrastró al cuarto y nuevamente la violó. Raquel pasó el resto de la noche bajo estado de terror, temiendo por el regreso de quien había abusado sexualmente de ella y por la seguridad y vida de su esposo.

\subsubsection{Resolución de la Comisión}

La Comisión Interamericana para entrar en estudio de la violencia sexual de Raquel Martín de Mejía comenzó por analizar el artículo 5 (integridad personal) de la CADH, en el sentido de que a pesar de contemplar la prohibición de la tortura, no contempla una definición de la misma. Por ello, emplea de forma complementaria la Convención Interamericana para Prevenir y Sancionar la Tortura, misma que sí establece una definición de tortura.

De esta forma, la Comisión concluye que de acuerdo a dicha definición se prevén tres elementos que deben conjugarse para la existencia de tortura, siendo los siguientes: 
"1. Que se trate de un acto a través del cual se inflijan a una persona penas y sufrimientos físicos y mentales;

\section{Cometido con un fin $y$;}

3. Por un funcionario público o por una persona privada a instigación del primero." 127

Es de observar que para el presente caso la Comisión no hace referencia al elemento de la intencionalidad, como parte de la definición, mismo que en resoluciones posteriores es incluido como parte de los elementos.

\subsubsection{Penas y sufrimientos físicos y mentales}

En cuanto al primer elemento, la Comisión considera que la violación es un abuso físico y mental que se perpetra como resultado de un acto de violencia. ${ }^{128}$ Retoma también lo señalado por el Relator Especial contra la Tortura, en el sentido de que la violación es uno de varios métodos de tortura física y que en Perú pareciera ser un arma utilizada para castigar, intimidar y humillar. ${ }^{129}$

La Comisión concluye que la violación sexual a la que fue sometida Raquel Mejía, es un acto de violencia a su integridad que le causo sufrimientos físicos y mentales, en el siguiente sentido:

"Raquel Mejía fue víctima de violación, y en consecuencia de un acto de violencia contra su integridad que le causó "penas y sufrimientos físicos y mentales"..., luego de ser violada "estaba en un estado de shock, sentada sola en [su] habitación". No se animó a realizar la denuncia pertinente por miedo a sufrir el "ostracismo público". "Las víctimas de abusos sexuales no denuncian estos hechos porque [se] sienten humilladas. Además nadie quiere reconocer públicamente que ha sido violada. No se sabe cómo

\footnotetext{
${ }^{127} \mathrm{CIDH}$, Caso Raquel Martín de Mejía Vs. Perú, Informe №5/96, Caso 10.979, $1^{\circ}$ de marzo de 1996, Consideraciones sobre el fondo del asunto, Apartado 3; Análisis

128 Ibídem.

${ }^{129}$ ONU, Consejo Económico y Social, U.N. Doc. E/CN.4/1986/15, 16 de febrero de 1986, Tortura y otros tratos o penas crueles, inhumanas y degradantes, Informe del Relator Especial Mr. P. Kooijmans Párr. 119
} 
puede reaccionar el marido. [Por otro lado] la integridad de la familia está en juego, los hijos pueden sentirse humillados de saber que esto le ha ocurrido a su madre."130

Lo anterior lo concluye a partir de la declaración de la propia agraviada, quien refiere el estado de shock en el que se encontraba, así como las razones para no realizar la denuncia correspondiente en la jurisdicción interna. Declaración a la cual la $\mathrm{CIDH}$ le da valor pleno, reforzando esta prueba testimonial con los informes de diversos organismos intergubernamentales y no gubernamentales donde se documenta la existencia de numerosas violaciones de mujeres en Perú, perpetradas por miembros de las fuerzas de seguridad en zonas de emergencia (cabe destacar que Raquel Martín vivía en zona de emergencia, donde las fuerzas armadas tomaban control) y donde se hace referencia al caso concreto de Raquel Mejía, describiéndolo como representativo de esta situación. Tales son los informes de Amnistía Internacional, el Relator Especial contra la Tortura y Human Rights Watch. ${ }^{131}$

Es de observarse que la Comisión utiliza el término "ostracismo público" para justificar el hecho de que Raquel no denunció los hechos relacionados con la violación sexual al momento de presentar su declaración en 1989 (con relación al secuestro y homicidio de su esposo) y expresa varias razones por las que las víctimas no denuncian estos hechos, lo cual simboliza un aporte fundamental a los estándares internacionales para la protección de los derechos humanos de las mujeres, pues resulta necesario conocer los obstáculos a los que se enfrentan las mujeres para el ejercicio y defensa de sus derechos, debido a su condición de género. Este estándar fue empleado más adelante (2001) en el caso Ana, Beatriz y Celia González Pérez Vs México.

A su vez profundiza con enfoque de género la imposibilidad de las mujeres víctimas de violación, por miembros de las fuerzas de seguridad o de la policía, de obtener un remedio a las violaciones de sus derechos, ya sea por humillación pública o la percepción de que los responsables nunca serán sancionados. Análisis que refuerza con lo documentado por

\footnotetext{
${ }^{130} \mathrm{CIDH}$, Raquel Martín de Mejía Vs Perú, op. cit., Consideraciones sobre el fondo del asunto, Apartado 3; Análisis.

${ }^{131}$ Ibídem., Consideraciones sobre el fondo del asunto, Apartado 1; Presunción de los hechos
} 
el Relator Especial contra la Tortura, quien en su informe de 1994 y en el apartado específico respecto a Perú, señala que:

“... los responsables de [violación y otros abusos sexuales] raramente eran procesados aún en aquellos casos que habían sido denunciados ante las autoridades competentes. Los tribunales militares pasaban por alto estos casos y no ponían a los acusados a disposición de los tribunales civiles, como deberían hacer de acuerdo con la ley. Esta situación de impunidad junto con otros factores tales como la dificultad de presentar pruebas o la actitud social hacia la víctima hacian que un gran porcentaje de estos casos ni siquiera fuesen denunciados. ${ }^{132}$

\subsubsection{La finalidad}

En cuanto al segundo elemento relativo a la finalidad en la comisión de la tortura, la Comisión refiere que:

"El segundo elemento establece que un acto para ser tortura debe haberse cometido intencionalmente, es decir con el fin de producir en la víctima un determinado resultado. La Convención Interamericana para Prevenir y Sancionar la Tortura incluye, entre otros fines, el castigo personal y la intimidación."133

Es de observarse que la Comisión vincula la intencionalidad con la finalidad, es decir que la intención tiene por objeto una finalidad. $\mathrm{Y}$ analiza ambos elementos como uno solo, a diferencia de cómo lo hará más adelante (2011) en la resolución del caso Gladys Carol Espinoza Gonzales Vs Perú, donde analizará ambos elementos de forma diferenciada, lo que implica la comprobación de un elemento más (la intencionalidad) para acreditar la tortura.

La CIDH determina que Raquel Mejía fue violada con la intención de castigarla personalmente e intimidarla, basándose en el testimonio donde Raquel declara que el

\footnotetext{
132 ONU, Comisión de Derechos Humanos, E/CN.4/1994/31, 6 de enero de 1994, Cuestión de los Derechos Humanos de todas las personas sometidas a cualquier forma de detención o prisión y en particular: La Tortura y otros tratos o penas crueles, inhumanas y degradantes, Informe del Relator Especial Mr. Nigel S. Rodley, párr. 433

${ }^{133} \mathrm{CIDH}$, Raquel Martín de Mejía Vs Perú, Consideraciones sobre el fondo del asunto, Apartado1; Presunción de los hechos
} 
miembro de las fuerzas de seguridad le manifestó que ella también era requerida como subversiva al igual que su esposo y que su nombre estaba en la lista de personas vinculadas al terrorismo, amenazándola con volver y violarla nuevamente. ${ }^{134}$

Es decir, sin que la Comisión profundice demasiado en este punto, su análisis permite presumir que la violación sexual perpetrada en contra de Raquel Mejía, se realiza con la intención o finalidad de castigarla por ser considerada como subversiva y terrorista y a su vez intimidarla.

\subsubsection{La comisión del acto por un oficial público o por una persona privada a instigación del primero.}

Por lo que hace al tercer elemento, la Comisión presume como ciertos los vejámenes ocasionados a Raquel Martín, con base a las pruebas aportadas relacionadas con el secuestro y homicidio de su esposo, estableciendo que:

“...los actos que afectaron al esposo de Raquel Mejía se encuentran estrechamente vinculados con los abusos sexuales de los que ésta fue víctima pues tuvieron lugar la misma noche y fueron perpetrados por los mismos individuos. Por este motivo, las pruebas circunstanciales aportadas, aun cuando no atañen directamente al caso en cuestión, resultan suficientes, en concepto de la Comisión, para presumir la responsabilidad de miembros del Ejército peruano en la comisión de los vejámenes contra Raquel Mejía."135

Es así que la Comisión concluye que el responsable de la violación sexual era un miembro de las fuerzas de seguridad que se hacía acompañar por un número importante de soldados, configurándose el tercer elemento para la tipificación de la tortura.

Una vez configurados los tres elementos, la $\mathrm{CIDH}$ concluye que el Estado peruano es responsable de la violación al artículo 5 de la Convención Americana.

\footnotetext{
${ }^{134}$ Ibídem.

${ }^{135}$ Ibíd.
} 
Posteriormente la Comisión analiza los hechos de violencia sexual en el marco del derecho a la honra y la dignidad, establecido en el artículo 11 de la Convención, lo cual no se retomará en la presente investigación por no ser objetivo de análisis de la misma.

\subsubsection{Análisis de los principales aportes de la resolución}

La presente resolución marca un hito importante en el análisis de género de la Comisión Interamericana, pero también en su esfuerzo por acreditar los elementos constitutivos del tipo penal de tortura, lo que no había hechos en los casos anteriores.

En este sentido, mediante la Convención Interamericana para Prevenir y Sancionar la Tortura, la Comisión determina la existencia de tres elementos (el acto a través del cual se inflijan penas o sufrimientos físicos y mentales; la finalidad; y cometido por un agente estatal o bajo instigación de éste) que deben conjugarse para la existencia de la tortura, en los cuales no refiere de forma enunciativa la intencionalidad, pero si lo vincula con la finalidad, lo que facilita la acreditación de tal elemento.

Resalta que por primera vez hace referencia al ostracismo público al que se enfrentan las víctimas de violencia sexual, y sobre todo toma en cuenta las razones por las que en la mayoría de los casos las víctimas no denuncian tales hechos, entre estas, el temor, la humillación, la integridad familiar, etc. Todas estas razones por las cuales las mujeres no denuncian tienen sustento en la construcción de género donde la mujer, social y culturalmente pierde su "valor como mujer" al ser víctima de violencia sexual. Dicho análisis la Comisión lo realiza para justificar las razones por las cuales la víctima no denunció inmediatamente en el ámbito interno, otorgándole pleno valor probatorio a su declaración.

Tal precedente es de gran importancia para la defensa de los derechos humanos de las mujeres, pues éstas constantemente se enfrentan ante el miedo a denunciar por múltiples consecuencias asociadas al género y muchas veces no lo hacen inmediatamente, por lo que los operadores de justicia restan credibilidad al testimonio de las víctimas, debido a la 
falta de sensibilidad para entender las consecuencias y efectos de la violencia sexual sobre las mujeres por su condición de género y el estado de shock en que pueden encontrarse.

De lo anterior puede observarse el enfoque de género en la resolución de dicho Organismo, pues visibiliza las consecuencias sociales y culturales que obstaculizan el acceso a la justicia para las mujeres víctimas de violencia sexual, obstáculos que radican en los roles estereotipados de género asignados a las mujeres y ligados a su feminidad, la cual descansa en el valor que se asigna socioculturalmente a la honra o pudor de la mujeres, pues es bien sabido que en muchos países las mujeres pierden valor y no son bien vistas cuando han sido ultrajadas sexualmente.

Finalmente la Comisión determina la responsabilidad estatal por la violación al artículo 5 de la Convención Americana, es decir, nuevamente la Comisión no señala expresamente el artículo 5.2, como si lo hace en casos posteriores, sin embargo durante su estudio de fondo si acredita la comisión de la tortura mediante la violación sexual, al analizar cada uno de los elementos que la configuran.

Es importante mencionar que un aspecto importante al que pudo deberse este avance en el análisis y posicionamiento de la Comisión Interamericana para acreditar la violencia sexual como constitutiva de tortura, pudo haber sido a que en el presente caso la Comisión se allego de una serie de elementos probatorios y en cierta medida de presión política, como lo fueron los informes de los diversos Organismos Intergubernamentales y No Gubernamentales, donde se documentó la existencia de numerosas violaciones de mujeres en Perú, es decir, que no se trataba de un caso aislado, sino de una práctica sistemática llevada a cabo por parte de las fuerzas de seguridad de Perú.

Por último, al igual que en la resolución anterior, para la fecha en que se emitió la presente resolución (01 de marzo de 1996) ya había entrado en vigor la Convención Interamericana para Prevenir, Sancionar y Erradicar la Violencia contra la Mujer (03 de mayo de 1995) y la Comisión no hizo uso de ésta, e independientemente de que Perú la ratificó con posterioridad a la emisión de la resolución, es decir el 02 de abril de 1996, la 
Comisión pudo haber hecho uso de las mima por lo menos a modo interpretativo, al tratarse de un asunto de violencia contra la mujer.

\subsection{Caso Dianna Ortiz Vs. Guatemala Informe de Fondo 31/96, Caso 10.526, del 16 de octubre de 1996}

Los hechos sucedieron en noviembre de 1989, la Comisión Interamericana abrió el caso N. 10.526 el 18 de abril de 1990, basándose en las declaraciones presentadas por la peticionaria. El 07 de febrero de 1995, la Comisión se pone a disposición de las partes a efectos de llegar a una solución amistosa, sin embargo, el gobierno de Guatemala comunicó a la Comisión que había decidido no participar de la solución amistosa.

En 1996, con base en el artículo 50 de la CADH, la Comisión aprobó el informe 9/96 durante su $91^{\circ}$ periodo ordinario de sesiones, donde realizó una serie de recomendaciones al gobierno de Guatemala, solicitándole informara sobre la adopción de medidas para dar cumplimiento a las mismas, en un lapso no mayor a sesenta días, caso contrario presentaría el caso ante la Corte. El gobierno solicitó dos prórrogas (de dos meses) para informar sobre el cumplimiento de las recomendaciones, la primera le fue concedida, la segunda no, sin embargo, el gobierno de Guatemala nunca respondió el informe $9 / 96$.

Dianna Ortiz solicitó a la Comisión que el caso no fuera sometido a la Corte por los efectos de re victimización que estaba viviendo, por lo que la Comisión decidió no someterlo y aprueba el informe 31/96 de conformidad con el artículo 51 de la CADH, publicando el Informe Anual a la Asamblea General de la OEA, ya que el Gobierno de Guatemala no adoptó las medidas para solucionar la situación denunciada dentro de los plazos concedidos.

\subsubsection{Resumen de los hechos}

La hermana Dianna Ortiz llegó por primera vez a Guatemala en septiembre de 1987 para unirse a varias monjas y trabajar con las poblaciones indígenas. A partir de 1989 comenzó a 
recibir cartas con amenazas anónimas, requiriéndole que dejara el país. En este contexto de amenazas fue abordada por un desconocido en la calle, quien la intimidó diciéndole "sabemos quién es usted, Usted está trabajando en Huehuetenango", las amenazas se agravaron al grado de recibir amenazas de muerte.

La Hermana Ortiz decidió refugiarse en la Posada de Belén, un centro religioso situado en Antigua, Guatemala, donde el 2 de noviembre de 1989 fue secuestrada por dos hombres (uno de ellos fue quien la abordó en la calle cuatro meses atrás), quienes la obligaran a subir a un ómnibus público amenazándola con una granada hasta que descendieron y caminaron por un camino de tierra, donde le vendaron los ojos y la subieron a un automóvil patrullero de la Policía Nacional, fue llevada al cuarto de un edificio donde la sentaron en una silla, le quitaron algunas de sus ropas y comenzaron a tocarla. Empezaron a interrogarla y después de cada pregunta la quemaban con un cigarrillo. En este proceso le mostraron fotografías de ella tomadas en distintas partes del país y otras de personas indígenas con armas, insistiéndole que la mujer indígena que aparecía en la fotografía era ella. Le colocaron nuevamente la venda, la golpearon en la cara, le quitaron el resto de sus ropas, comenzaron a abusar de ella sexualmente y la violaron varias veces, amenazándola con que dejarían de hacerlo hasta que ella les diera los nombres de las personas de las fotografías. Ella se desmayó y al recuperar el conocimiento se encontraba atada de las muñecas, nuevamente comenzaron a interrogarla y fue violada por segunda ocasión.

Posteriormente la bajaron a un foso lleno de cuerpos y de ratas, donde desmayó, al despertar estaba en el suelo y estaban abusando de ella sexualmente.

Más tarde la regresaron al cuarto, donde volvieron a interrogarla, la sujetaron al piso y la volvieron a violar, hasta que entró un hombre de nombre Alejandro, quien les dijo a los otros que la Hermana Ortiz era ciudadana americana y que la debían dejar en paz, les ordenó que salieran del cuarto, la ayudo a vestirse y la llevó fuera del edificio en un auto. Cuando se detuvo por el tráfico ella saltó y huyó, 48 horas después de haber escapado estaba en camino a Estados Unidos. 


\subsubsection{Resolución de la Comisión}

La Comisión determinó que la hermana Dianna Ortiz fue secuestrada y torturada a principios de noviembre de 1989 con base a las siguientes pruebas: sus declaraciones escritas y orales; la reconstrucción judicial; dos valoraciones médicas que dan fe de las lesiones que presentaba por quemaduras de primer y segundo grado; y la observación personal del embajador de Estados Unidos. ${ }^{136}$

Respecto a los actos de violencia sexual, como la desnudez forzada, el tocamiento y las violaciones sexuales, la Comisión consideró:

"que hay una alta probabilidad de que la Hermana Ortiz haya sido violada durante el tiempo en que estuvo detenida. Las declaraciones de la Hermana Ortiz contienen evidencia importante que indican que la violación ocurrió y la violación guardaría relación con la evidencia física que muestra que fue brutalmente torturada. Sin embargo, basándose en la cuidadosa examinación del expediente, la Comisión no se encuentra en condiciones de afirmar con suficiente certeza la alegación de la violación. De cualquier modo, la Comisión ha concluido que la Hermana Ortiz fue objeto de tortura; cualquier violencia sexual o abuso que hubiera ocurrido formaría parte de la tortura."

La Comisión por un lado menciona que las declaraciones de la hermana contienen evidencia importante que acreditarían la violación sexual y que ésta guarda relación con la evidencia física que muestra que fue torturada, sin embargo no lo da por acreditado.

Esta situación refleja de cierta forma el valor que la Comisión otorgó a la pruebas, pues en el informe 31/96 no se hace referencia alguna a la existencia de valoraciones ginecológicas que acrediten la violación sexual, a diferencia de las lesiones físicas en el cuerpo, donde si existen dos valoraciones médicas que certifican las lesiones, ${ }^{138}$ sobre todo las quemaduras en la espalda. Sin embargo, sí existe en el expediente una carta del psiquiatra de la Hermana Ortiz

\footnotetext{
${ }^{136} \mathrm{CIDH}$, Caso Dianna Ortiz vs Guatemala, Informe de Fondo 31/96, Caso 10.526, del 16 de octubre de 1996, párr. 49-52

${ }^{137}$ Ibídem, párr. 53

${ }^{138}$ Ibíd., párr. 50
} 
donde detalla la reacción de ésta a la tortura y la violación sexual, y en la que explica las razones que hacen difícil que presente pruebas o información adicional sobre la violación, lo que aunado a las declaraciones orales y escritas de la víctima, pudieron haber sido prueba plena para que la Comisión acreditara la violación sexual en el marco de las demás torturas infligidas y plenamente acreditadas.

En lo más específico, respecto a los actos de tortura, emplea la definición contenida en el artículo 2 de la Convención Interamericana para Prevenir, y Sancionar la Tortura y analiza brevemente la comisión de los elementos que la configuran, en el siguiente sentido:

“... Los agentes del Gobierno infligieron sufrimiento físico y mental a Dianna Ortiz, presumiblemente para castigarla e intimidarla por su participación en ciertas actividades y por su asociación con ciertas personas o grupos, La tortura aplicada a Dianna Ortiz se asemeja mucho a la descripción de métodos utilizados para "anular la personalidad de la víctima."

Por último, en las conclusiones de derecho, ${ }^{140}$ al analizar el artículo 5 de la CADH, la Comisión tipifica las amenazas por medio de cartas y el enfrentamiento personal como una violación a la integridad física, psíquica y moral, con base en el artículo 5.1 de la Convención, asimismo encuentra el secuestro, detención y tortura de Dianna Ortiz como violatorias al artículo 5.2 de la CADH.

\subsubsection{Análisis de los principales aportes de la resolución}

El presente caso, a diferencia del anterior, no contiene un análisis de género en la resolución de la Comisión, de hecho ésta no entra a un estudio profundo de la violación sexual y del valor de la a declaración de la víctima.

La Comisión pudo haber dado por sentada la existencia de la violación sexual, dándole mayor valor probatorio a las declaraciones de la víctima, pudo haber empleado la carta del

\footnotetext{
139 Ibíd. párr. 109

${ }^{140}$ Ibídem., párr. 106-108
} 
psiquiatra como un elemento de prueba convincente, pero sobre todo tomando en cuenta que la violencia sexual es empleada en contra de las mujeres (por su condición de género) como un mecanismo de tortura para la obtención de confesiones o como castigo, tal y como lo analizó en el caso Raquel Martin de Mejía; al referir que ella no había denunciado los hechos por miedo al ostracismo público o a sentirse humillada y que las mujeres no denuncian por no querer reconocer públicamente que han sido violadas. Situación que se agrava en el caso de la Hermana Dianna Ortiz por su condición de religiosa o representante de la iglesia, donde posiblemente una violación sexual implica un doble peso moral; el de género y el de religión.

Es decir, en el caso Raquel Martín de Mejía la Comisión sí le otorgó pleno valor probatorio a la declaración de la víctima (con relación a la violación sexual como método de tortura) y reforzó la prueba con los informes de los organismos intergubernamentales y gubernamentales que documentan las violaciones de mujeres en Perú.

En este caso la Comisión por un lado refiere que existe evidencia importante que indica que la violación sexual ocurrió, sin embargo no está en condiciones de afirmarlo, manifestando que de cualquier forma dicha violación formaría parte de la tortura que ya está acreditada. No obstante hubiera sido importante reconocer la violencia sexual como tortura, ya que permite vincular la violencia de género contra las mujeres como estratégica para la obtención de ciertos fines.

Nuevamente el presente caso no interpreta la Convención Interamericana para Prevenir, Sancionar y Erradicar la Violencia contra la Mujer siendo que Guatemala ratificó dicho instrumento el 01 de abril de 1995 y ésta entró en vigor el 03 de mayo de 1995. 


\subsection{Caso Ana, Beatriz y Celia González Pérez Vs México Informe de fondo 53/01, Caso 11.565, de 04 de abril de 2001}

El caso de las hermanas González es el primer caso que conoce la CIDH relacionado a actos de violencia sexual como mecanismo de tortura, por parte de miembros del ejército Mexicano.

Los hechos del presente caso sucedieron el 04 de junio de 1994 en el estado de Chiapas, México, el 16 de enero de 1996 la Comisión recibió la denuncia donde se alegó la responsabilidad internacional del Estado por la detención ilegal, violación y tortura de las hermanas Ana, Beatriz y Celia González Pérez, indígenas tzeltales, así como la posterior falta de investigación y reparación del daño.

La Comisión declaró la admisibilidad del caso el 19 de noviembre de 1999, emitiendo el informe 129/99 y poniéndose a disposición de las partes para propiciar una solución amistosa, sin embargo, el Estado no aceptó el ofrecimiento de la solución amistosa.

El 19 de marzo de 2001 la Comisión transmitió al Estado el Informe de fondo 32/01, otorgándole un plazo de 15 días para que informara sobre la adopción de medidas para el cumplimiento de las recomendaciones efectuadas, sin embargo, el 04 de abril del mismo año, el Estado remitió comunicación a la Comisión, manifestándole que la investigación debería llevarse a cabo por la Justicia Militar por ser la competente y que la reparación del daño sería resultado de un proceso que determine la culpabilidad. Por ende, la Comisión al considerar que dicha información no refiere iniciativa o medida alguna para dar cumplimiento a las recomendaciones, decidió reiterar las conclusiones y recomendaciones mediante el informe No. 53/01, del 04 de abril de 2001, así como hacer público el informe con fundamento en el artículo 51.3 de la CADH.

\subsubsection{Resumen de los hechos}

El 4 de junio de 1994 un grupo de militares detuvo ilegalmente en el estado de Chiapas, México, a las hermanas Ana, Beatriz y Celia González Pérez y a su madre Delia Pérez de 
González para interrogarlas con el objeto de hacerles confesar su pertenencia al Ejército Zapatista de Liberación Nacional (EZLN), manteniéndolas privadas de su libertad durante dos horas. En este tiempo las tres hermanas fueron separadas de su madre, golpeadas y violadas en reiteradas ocasiones por los militares, también fueron amenazadas de muerte en caso de denunciar lo sucedido.

Las mujeres hablan el idioma de la etnia tzeltal y su conocimiento del castellano es muy limitado, en virtud de lo cual tuvieron dificultad para comprender las preguntas que les formularon.

El 30 de junio de 1994, se presentó la denuncia al Ministerio Público Federal con base en un examen médico ginecológico, sin embargo, en septiembre del mismo año el expediente fue trasladado a la Procuraduría General de Justicia Militar por incompetencia en razón de la materia. A partir de la cesión de competencia a la jurisdicción militar no hubo avance alguno sustancial en las investigaciones y en febrero de 1996 se decidió archivar el expediente ante la falta de comparecencia de las agraviadas para declarar nuevamente y someterse a nuevas pruebas ginecológicas.

\subsubsection{Resolución de la Comisión}

En el análisis de la violación sexual como constitutiva de tortura la Comisión comenzó por hacer referencia al examen médico ginecológico realizado a las víctimas, en el sentido de que tal prueba médica a pesar de haber sido presentada en tiempo y forma, no fue considerada en el marco de un procedimiento ajustado a derecho, pues la justicia militar no le otorgó valor solicitando se realizara un nuevo examen meses después de sucedidos los hechos.

Ante tal situación, la Comisión hizo referencia a los principios (definidos por la Comisión de Derechos Humanos de Naciones Unidas) que deben acatar los profesionales médicos en la investigación de denuncias sobre tortura, entre los que se ubica la redacción inmediata por parte del médico experto de un "informe fiel" que debe contener los 
siguientes elementos: las circunstancias de la entrevista; el historial; el examen físico y psicológico; la opinión (interpretación de la relación entre los síntomas físicos y psicológicos y las posibles torturas o malos tratos); y la autoría ${ }^{141}$. De esta forma, concluyó que el examen médico practicado a las hermanas González Pérez reunía los parámetros establecidos por las Naciones Unidas, por lo que no era necesario practicar nuevo examen médico.

Posteriormente la CIDH sin entrar a un análisis detallado de cada uno de los elementos que configuran la tortura, concluyó que:

“...Ana, Beatriz y Celia González Pérez fueron sometidas a un interrogatorio ilegal, en medio de abusos físicos que incluyeron la violación sexual de las tres hermanas. Tales hechos fueron perpetrados... por un grupo de militares mientras las hermanas se hallaban privadas ilegítimamente de su libertad. El contexto en que sucedieron tales hechos conduce igualmente a la conclusión de que fueron cometidos con el fin de amedrentar a las tres mujeres por sus presuntos vínculos con el EZLN. La CIDH establece además que, como consecuencia de la humillación generada por este cuadro de abusos, las hermanas González Pérez y su madre tuvieron que abandonar su lugar de residencia habitual y su comunidad." 142

Con esta conclusión la CIDH reflejó la acreditación de los elementos constitutivos de tortura, es decir, las penas o sufrimientos físicos o mentales generadas por los abusos físicos, que incluyeron la violación sexual y la humillación generada por el cuadro de abusos, aunado al tener que abandonar la residencia y comunidad; la finalidad de amedrentar a las tres mujeres por sus presuntos vínculos con el EZLN; y la comisión del acto perpetrado por agentes estatales (un grupo de militares).

Respecto a la finalidad en la comisión del acto, la Comisión refirió que:

\footnotetext{
${ }^{141}$ CIDH, Caso Ana, Beatriz y Celia González Pérez Vs México, informe de fondo 53/01, 04 de abril de 2001, párr.39

${ }^{142}$ Ibídem., párr. 42
} 
"por la manera en que las atacaron, las acusaciones que les hicieron, y las graves amenazas, es razonable sostener además que los militares quisieron humillar y castigar a las mujeres por su presunta vinculación a los rebeldes." 143

Para reforzar su análisis, retomó estándares internacionales ya establecidos, reseñando que "... la violación y otras formas de ataque sexual están expresamente prohibidas bajo el derecho internacional.", ${ }^{144}$ que las agresiones sexuales en el marco de conflictos armados "a menudo se considera y practica como medio para humillar al adversario, [y que las consecuencias] "son devastadoras para las víctimas desde el punto de vista físico, emocional y psicológico", 145 que "La violación produce un sufrimiento físico y mental en la víctima, les ocasiona un trauma psicológico que resulta, por un lado, del hecho de ser humilladas y victimizadas y por el otro, de sufrir la condena de los miembros de su comunidad, si denuncian los vejámenes de los que fueron objeto...", ${ }^{146}$ que "La violación es uno de los métodos de tortura física, utilizada en algunos casos para castigar, intimidar y humillar"147 y que "...La violación se utiliza por el propio interrogador..., como medio de castigar, intimidar, coaccionar o humillar a la víctima, o de obtener información, o una confesión de la víctima o de una tercera persona."148

Asimismo, la CIDH hace referencia al derecho de las mujeres a una vida libre de violencia contemplado en la Convención Interamericana para Prevenir, Sancionar y Erradicar la violencia contra las mujeres, Convención de Belém do Pará.

Otro aspecto a destacar es que la Comisión extiende la responsabilidad del Estado por la violación del derecho a la integridad personal de la Sra. Delia (madre de las 3 hermanas),

\footnotetext{
${ }^{143}$ Ibíd., párr. 51

${ }^{144}$ Tribunal Penal Internacional para la Ex Yugoslavia, Caso Celebici, Caso No. IT-96-21-T, Sentencia 16 de noviembre de 1998, párr. 476, citado por CIDH, Caso Caso Ana, Beatriz y Celia González Pérez Vs México, op. cit., párr.45

${ }^{145} \mathrm{ONU}$, Informe presentado por la Sra. Radhika Coomarasway, Relatora Especial sobre la violencia contra la mujer, con inclusión de sus causas y consecuencias, de conformidad con la resolución 1997/44 de la Comisión, E/CN.4/1998/54, 26 de enero de 1998, párr. 13 y 14, citado por CIDH, Caso Ana, Beatriz y Celia González Pérez Vs México, op. cit., párr.45

${ }^{146} \mathrm{CIDH}$, Raquel Martín de Mejía Vs Perú, Supra nota 118, citado por CIDH, Caso Ana, Beatriz y Celia González Pérez Vs México, op. cit., párr. 47

${ }^{147}$ ONU, Informe del Relator Especial Mr. P. Kooijmans, Tortura y otros Tratos o Penas Crueles, Inhumanas o Degradantes, E./CN.4/1986/15, 19 de febrero de 1986, párr. 119 y 431, citado por CIDH, Caso Ana, Beatriz y Celia González Pérez Vs México, op. cit., párr. 48

${ }_{148}$ Tribunal Penal Internacional para la Ex Yugoslavia, Caso Furundzija, sentencia del 10 de diciembre de 1998, párr. 163, citado por $\mathrm{CIDH}$, Caso Ana, Beatriz y Celia González Pérez Vs México, op. cit., párr. 49
} 
quien tuvo que presenciar la vejación de sus tres hijas por integrantes de las fuerzas armadas y luego compartir con ellas el ostracismo de su comunidad, estableciendo que:

"De acuerdo a la jurisprudencia internacional de derechos humanos, en ciertas circunstancias, la angustia y el sufrimiento impuestos a los familiares directos de las víctimas de violaciones graves de derechos humanos configuran adicionalmente una violación del derecho a la integridad personal de aquéllos."

Con estos elementos concluyó que la violencia sexual y los abusos psicológicos ejercidos contra las hermanas González constituyen tortura y una violación de la vida privada de las cuatro mujeres y de su familia, así como un ataque ilegal a su honra o reputación que las llevó a huir de su comunidad en medio del temor, la vergüenza y humillación. Por lo que el Estado mexicano es responsable por la violación del artículo 5 y 11 de la CADH.

También determinó la responsabilidad internacional de México por la violación del artículo 19 de la $\mathrm{CADH}$, en perjuicio de Celia González Pérez (menor de edad), con relación al artículo 1.1 del mismo instrumento.

\subsubsection{Análisis de los principales aportes de la resolución}

Uno de los aspectos más importantes de esta resolución es la confirmación de los principios que deben acatar los profesionales médicos en la investigación de denuncias de tortura, pero sobretodo su vínculo con el examen médico practicado a las víctimas, al cual no se le otorgó valor por parte de la justicia militar, a pesar de cumplir con los requisitos referidos por los principios.

Lo anterior es un elemento importante para ser empleado en la defensa de los derechos humanos de las mujeres en casos similares, donde se coloca a las mismas en situaciones de re victimización al tener que volver a someterse a un examen ginecológico que resulta invasivo para ellas, dadas las circunstancias de la violencia sexual.

\footnotetext{
${ }^{149} \mathrm{CIDH}$, Caso Ana, Beatriz y Celia González Pérez Vs México, op. cit., párr. 53
} 
Es sustancial también el análisis de la Comisión con relación a las consecuencias de la violación sexual al hacer referencia a la humillación, la vergüenza, el abandono de su lugar de residencia y la condena por los miembros de su comunidad, lo que vincula al ostracismo público por parte de su comunidad. Análisis que la Comisión ya había empleado en el caso Raquel Martín de Mejía, sin embargo, nuevamente se deja ver el enfoque de género en la resolución, donde observa las consecuencias más allá de los daños físicos y resalta consecuencias vinculadas a los prejuicios de género a los que se enfrentan las mujeres víctimas de violencia sexual.

La resolución genera aportes respecto a la tipificación de la tortura cuya finalidad varia de la obtención de confesiones, pues en este caso la Comisión refiere que los militares querían humillar y castigar a las mujeres por sus presuntos vínculos con los "rebeldes", y que la agresión sexual es una práctica para humillar al adversario. Lo que permite observar como el acceso al cuerpo de las mujeres se convierte en un campo de batalla con fines estratégicos para debilitar y humillar a los adversarios, lo que a su vez deduce la manifestación de las relaciones desiguales de poder entre los géneros que se manifiestan mediante la violencia.

Otro estándar importante es la ampliación del alcance de protección del derecho a la integridad, pues la Comisión extiende su alcance para proteger a la madre de las víctimas por tener que presenciar los vejámenes cometidos contra sus hijas y vivir el ostracismo de su comunidad.

Asimismo, la Comisión emplea en su análisis la Convención Interamericana para Prevenir, Sancionar y Erradicar la Violencia contra la Mujer, al hacer referencia al derecho de las mujeres a una vida libre de violencia, más no para responsabilizar al Estado Mexicano por la violación a dicha Convención, como si lo hace con la Convención Interamericana para Prevenir y Sancionar la Tortura. Sin embargo, es un avance la incorporación de la Convención de Belém do Pará en el marco de las resoluciones de la Comisión. 
En este sentido es importante mencionar que México ratificó dicha Convención con fecha del 19 de junio de 1998, una vez entrada en vigor y casi tres años antes de la presente resolución.

\subsection{Caso Gladys Carol Espinoza Gonzales Vs Perú Informe de Admisibilidad y Fondo 67/11, Caso 11.157, del 31 de marzo de 2011}

Los hechos iniciaron el 28 de marzo de 1987, la petición se presentó a la Comisión el 10 de mayo de 1993 siendo registrada bajo el número 11.157, se trasladó al Estado y se le otorgó plazo de noventa días para presentar respuesta, misma que fue enviada en septiembre del 1993 y adicionalmente en junio de 1996 y agosto de 1998.

En enero de 1999 la Sra. Teodora Gonzáles presentó una comunicación donde narraba las condiciones de detención de Gladys, la comunicación fue registrada como una nueva petición bajo el número 12.079, nuevamente se le dio plazo de noventa días al Estado para que respondiera. En junio de 1999 la Comisión decidió acumular ambos expedientes bajo el primer registro.

En noviembre del 2004 se abrió el caso, difiriendo el tratamiento de admisibilidad hasta el debate del fondo.

En octubre de 2008 en el marco del $133^{\circ}$ periodo ordinario de sesiones, la Comisión sostuvo audiencia privada sobre el fondo del caso y el 08 de diciembre de 2011 la Comisión presentó el caso ante la Corte.

\subsubsection{Resumen de los hechos}

El 28 de marzo de 1987 Gladys Carol Espinoza Gonzáles fue detenida por primera vez y conducida con violencia a las instalaciones de la Dirección Contra el Terrorismo (DIRCOTE) en Lima, donde estuvo por 15 días y fue sometida a desnudez forzada, estiramientos y otras formas de agresión. Fue acusada de participar en saqueos a 
establecimientos comerciales como integrante del Movimiento Revolucionario Túpac Amaru (MRTA). El 28 de abril fue trasladada al Penal Miguel Castro Castro y el 13 de abril de 1988 salió en libertad tras obtener sentencia absolutoria.

El 17 de abril de 1993 Gladys fue intervenida en la vía pública por decenas de integrantes de la División de Investigación de Secuestro (DIVISE) vestidos de civil, quienes la obligaron junto con su esposo a subir al vehículo oficial mediante golpizas, amenazas y disparos al aire. Fue trasladada a la división policial, sometida a torturas, insultos y vejaciones

Para esta fecha se encontraban vigentes los decretos de leyes que autorizaban la incomunicación absoluta a personas investigadas por terrorismo o traición a la patria y prohibían la interposición de acciones de habeas corpus.

La Sra. Gladys fue sometida a interrogatorios en los que fue objeto de golpizas en la cabeza, rostro, miembros superiores y región lumbar "pellizcos en los senos", pinchazos con agujas en los pies, desnudez forzada e introducción de objetos en su vagina y ano. Fue sumergida en un tanque con desechos fecales, colgada de los pies y manos, y en varias ocasiones sufrió convulsiones, alucinaciones, desmayos y pérdida del sentido del dolor. Amenazaron con hacer daño a su familia e inyectarle VIH.

El 19 de abril de 1993 fue trasladada a los calabozos de la Dirección Nacional contra el Terrorismo (DINCOTE), donde se aduce que siguieron ocurriendo las violaciones sexuales, tortura y humillaciones. Las lesiones físicas y mentales se encontraban acreditadas en exámenes del Instituto de Medicina Legal y de la Policía Nacional.

En junio de 1993 fue condenada a cadena perpetua y durante el periodo de 1993 al 2001 fue trasladada a diversos penales de máxima seguridad, donde seguía recibiendo malos tratos, no contaba con atención médica y alimentación adecuada, y era sometida a aislamiento continuo.

En enero de 2003, tras el nuevo marco legislativo en materia de terrorismo, el proceso militar de Gladys fue declarado nulo y se abrió nueva instrucción en el fuero ordinario. El 
01 de marzo de 2004 se le condenó a 15 años de cárcel y el 24 de noviembre del mismo año se le elevó la condena a 25 años.

\subsubsection{Resolución de la Comisión}

En el análisis de los hechos la Comisión observa con base a los informes finales de la Comisión de la Verdad y Reconciliación de Perú y el Informe sobre la Situación de Derechos Humanos en Perú, el contexto general ${ }^{150}$ en que sucedieron los hechos, entre los que se constató una práctica generalizada de violencia sexual contra las mujeres en la lucha contra-subversiva por parte de las fuerzas de seguridad de Perú.

Por su parte, en el análisis de los hechos probados, la Comisión da por probado tres situaciones:

1. La Sra. Gladys fue detenida por varios efectivos de la DIVISE, siendo sometida a golpizas, amenazas e insultos, sin que mediara orden judicial, ${ }^{151}$ y entre el 17 de abril y el 24 de junio de 1993, estuvo en situación de incomunicación absoluta; ${ }^{152}$

2. Fue objeto de actos deliberados de violencia bajo la custodia de agentes de la DIVISE y DINCOTE, entre estos, vejaciones, amenazas, golpizas, ahogamientos en tanques de agua mezclada con excremento, colgamientos, manoseos, penetración anal con objeto de madera, penetración vaginal con la mano de sus agresores y realización forzada de sexo oral; ${ }^{153}$

3. Fue sometida a condiciones de detención severas en el Penal de Yanamayo entre el 17 de enero de 1996 y el 17 de abril de 2001, sin tratamiento médico, alimentación

\footnotetext{
${ }^{150}$ En 1980 la dirección del Partido Comunista del Perú (Sendero Luminoso) puso en marcha un proyecto para derribar el sistema democrático-representativo de gobierno, las tácticas de dicho grupo generaron desplazamientos, aniquilamientos, hechos de violencia, entre otros actos. En este contexto de guerra revolucionaria del pueblo, en 1984, el Movimiento Revolucionario Túpac Amaru (MRTA), contribuyo a la inseguridad y violación a derechos humanos en Perú. Es en este marco que las fuerzas policiales y militares de Perú, en la lucha contra ambos grupos, incurrieron en prácticas al margen de la ley y en graves violaciones a los derechos humanos, entre estas, detenciones arbitrarias, torturas, tratos crueles, inhumanos y degradantes, violaciones sexuales, ejecuciones extrajudiciales y desapariciones forzadas en contra de personas que no tenían vínculo con ambos grupos armados irregulares.

${ }^{151} \mathrm{CIDH}$, Caso Gladys Carol Espinoza Gonzales Vs. Perú, Informe de Admisibilidad y Fondo 67/11, Caso 11.157, del 31 de marzo de 2011, párr. 101 y 108

${ }^{152}$ Ibídem., párr. 114

${ }^{153}$ Ibíd., párr. 140
} 
adecuada y sin posibilidad de recibir visitas, así también le propinaron golpizas en partes sensibles del cuerpo el 5 de agosto de $1999 .^{154}$

Más adelante la Comisión realiza el análisis de derecho, donde se pronuncia con relación a la violación al derecho a la libertad personal, y en segunda instancia analiza el derecho a la integridad personal y a la protección de la honra y la dignidad, establecidos en los artículos 5 y 11 de la CADH, así como a la obligación de prevenir y sancionar la tortura, establecida en los artículos 1 y 6 de la CIPST.

Respecto a los hechos de tortura, la Comisión emplea a modo de fundamento estándares internacionales que resultan de gran utilidad para la fundamentación y defensa del derecho de las mujeres a una vida libre de violencia, incluida la tortura, pero sobre todo para distinguir actos de tortura de otros tratos o penas crueles, inhumanos o degradantes, entre otros destacan los siguientes:

“...las amenazas y el peligro real de someter a una persona a lesiones físicas produce, en determinadas circunstancias, una angustia moral de tal grado que puede ser considerada tortura psicológica. "155

“...las lesiones, sufrimientos, daños a la salud o perjuicios sufridos por una persona privada de libertad pueden llegar a constituir una forma de pena cruel cuando, debido a las condiciones de encierro, exista un deterioro de la integridad física, psíquica y moral, que está estrictamente prohibido por el artículo 5.2 de la Convención." 156

\footnotetext{
${ }^{154}$ Ibíd., párr. 152

${ }^{155}$ ColDH, Caso del Penal Miguel Castro Castro Vs. Perú, Fondo, Reparaciones y Costas, Sentencia de 25 de noviembre de 2006, párr 272, Caso Baldeón García Vs. Perú, Fondo, Reparaciones y Costas, Sentencia de 6 de abril de 2006, párr. 119, Caso Tibi Vs. Ecuador Sentencia de 7 de septiembre de 2004, párr. 147 y Caso Maritza Urrutia Vs. Guatemala, Sentencia de 27 de noviembre de 2003, párr. 174

${ }^{156}$ ColDH, Caso Lori Berenson Mejía Vs. Perú, Sentencia de 25 de noviembre de 2004, párr. 101, citado por CIDH, Caso Gladys Carol Espinoza Gonzáles Vs. Perú, op.cit., párr. 175
} 
"...para que una conducta sea calificada como tortura deben concurrir los siguientes elementos: i) que sea un acto intencional, ii) que cause intenso sufrimiento físico o mental y iii) que se cometa con determinado fin o propósito." ${ }^{157}$

El último estándar resulta de interés, pues la Comisión hace mención de la intencionalidad como un elemento más de la tortura, haciendo referencia al caso Raquel Martín de Mejía, en donde la misma Comisión había vinculado de forma implícita la intencionalidad en el marco de la finalidad.

Asimismo emplea estándares respecto a la responsabilidad de los Estados por actos de tortura y otros tratos o penas crueles, inhumanos o degradantes, en el siguiente sentido: "...el Estado puede ser considerado responsable por torturas, tratos crueles, inhumanos o degradantes, si las autoridades respectivas no realizan una investigación seria en torno a hechos de esa naturaleza cometidos en perjuicio de personas que se encuentran bajo su custodia." ${ }^{158}$

“...en el caso de las personas privadas de libertad, la obligación de los Estados de respetar la integridad física, de no emplear tratos crueles e inhumanos y de respetar la dignidad inherente al ser humano, se extiende a garantizar el acceso a una atención médica adecuada." ${ }^{\prime 159}$

Con estos elementos de análisis la Comisión determina que la incomunicación continua equivale a tratos crueles, inhumanos y degradantes.

En cuanto a los hechos de violencia cometidos contra Gladys por agentes de la DIVISE y DINCOTE, establece que éstos:

\footnotetext{
${ }^{157}$ CIDH, Caso Raquel Martin Mejía Vs. Perú Informe No. 5/96, Caso 10.970, Fondo, 1 de marzo de 1996, sección 3. análisis y ColDH, Caso Bueno Alves Vs. Argentina, Sentencia de 11 de mayo de 2007, párr. 79, citado por CIDH, Caso Gladys Carol Espinoza Gonzáles Vs. Perú, op.cit., párr. 174

${ }^{158}$ ColDH, Caso Baldeón García Vs. Perú, Fondo, Reparaciones y Costas. Sentencia de 6 de abril de 2006, párr. 120 y ColDH, Caso de los "Niños de la Calle" (Villagrán Morales y otros Vs. Guatemala), Sentencia de 19 de noviembre de 1999, párr. 170, citados por CIDH, Caso Gladys Carol Espinoza Gonzáles Vs. Perú, op.cit., párr. 176

${ }^{159} \mathrm{CIDH}$, Caso 11.535, Caso Pedro Miguel Vera Vera Vs Ecuador, 24 de febrero de 2010, párr. 42, ColDH, Caso Montero Aranguren y otros (Retén de Catia) Vs. Venezuela, Sentencia de 5 de julio de 2006, párr. 102 y 103, ColDH, Caso De Ia Cruz Flores Vs. Perú, Sentencia de 18 de noviembre de 2004, párr. 132 y ColDH, Caso Tibi Vs. Ecuador, Sentencia de 7 de septiembre de 2004, párr. 157, citados por CIDH, Caso Gladys Carol Espinoza Gonzáles Vs. Perú, op.cit., párr. 177
} 
"...fueron cometidos de forma deliberada, con la finalidad de humillarla, disminuir su resistencia física y psicológica, y obtener información sobre su presunta participación en actividades ilícitas. Asimismo, se ha dado por probado que tales actos infligieron un sufrimiento de gran intensidad a la víctima, quien adquirió una serie de secuelas físicas y psíquicas..."160

Por tanto concluye que son constitutivos de tortura en los términos del artículo 5.2 de la Convención Americana, con conexión a la obligación establecida en el artículo 1.1 del mismo instrumento, y violó los artículos 1 y 6 de la CIPST.

En la tercera situación probada, es decir, las condiciones de detención y hechos de violencia en el Penal de Yanamayo, y en específico a los sucesos del 5 de agosto de 1999, la Comisión determina que con la información que se cuenta, las autoridades penitenciarias e integrantes de la DINOES (Dirección Nacional de Operaciones Especiales de la Policía Nacional del Perú) se ensañaron con las internas del Pabellón 1D, propiciándoles golpizas de forma deliberada y con la finalidad de castigarlas, lo que provocó en Gladys un sufrimiento físico de gran intensidad. Por ello concluye que dichos hechos son constitutivos de tortura, en términos del artículo 5.2 de la CADH y 2 de la CIPST. $^{161}$

En lo específico a la violencia sexual ejercida en contra de Gladys por parte de la Policía Nacional de Perú: desnudez forzada, vejaciones, manoseos, penetración anal con un objeto de madera, penetración vaginal con la mano de sus agresores y ser forzada a tener sexo oral, la Comisión a efectos de fundamentar su análisis emplea la jurisprudencia internacional emitida en los casos Valentina Rosendo Cantú y otra Vs. México, Inés Fernández Ortega Vs. México, Ana, Beatriz y Celia González Vs México y Penal Castro Castro Vs. Perú, en el siguiente sentido:

"...la violación sexual cometida por miembros de las fuerzas de seguridad contra integrantes de la población civil constituye en todos los casos una grave violación a

\footnotetext{
${ }^{160} \mathrm{CIDH}$, Caso Gladys Carol Espinoza Gonzales Vs. Perú, op. cit., párr. 179

${ }^{161}$ Ibídem., párr. 187
} 
los derechos humanos protegidos en los artículos 5 y 11 de la Convención Americana $^{162}$. Dicha conducta presupone un sufrimiento físico y mental severo $y$ duradero, debido a su naturaleza no consensual e invasiva y que afecta a la víctima, su familia y comunidad. Esta situación se agrava cuando el agresor es un agente estatal, por su posición de autoridad y por el poder físico y psicológico que puede ejercer sobre la víctima."

"[la violación sexual incluye] actos de penetración vaginales o anales, sin consentimiento de la víctima, mediante la utilización de otras partes del cuerpo del agresor u objetos, así como la penetración bucal mediante el miembro viril"164 y “...constituye una forma paradigmática de violencia contra las mujeres cuyas consecuencias trascienden a la persona de la víctima. "165

Otro estándar internacional de gran importancia que empleó la Comisión para referirse a la finalidad con la que se emplea la tortura y en específico la violación sexual como constitutiva de ésta, fue el desarrollado en el caso Furundzija por el Tribunal Penal Internacional para la Ex Yugoslavia:

"La violación se utiliza por el propio interrogador o por otras personas asociadas con el interrogatorio de una persona detenida, como medio de castigar, intimidar, coaccionar o humillar a la víctima, o de obtener información, o una confesión de la víctima o de una tercera persona. ${ }^{166}$

Con estos y otros estándares jurisprudenciales la Comisión determina que los actos de violencia sexual cometidos en contra de Gladys se realizaron cuando la víctima se

\footnotetext{
${ }^{162} \mathrm{CIDH}$, Demanda ante la Corte Interamericana de Derechos Humanos, Caso Valentina Rosendo Cantú y otra Vs. México, Caso 12.579, 2 de agosto de 2009, párr. 60, CIDH, Demanda ante la Corte Interamericana de Derechos Humanos, Caso Inés Fernández Ortega Vs México, Caso 12.580, 7 de mayo de 2009, párr. 88 y CIDH, Caso Ana, Beatriz y Cecilia González Pérez Vs. México, Informe No. 53/01, Caso 11.565, Fondo, 4 de abril de 2001, párr. 45, citados por CIDH, Caso Gladys Carol Espinoza Gonzales Vs. Perú, op. cit., párr. 190

${ }^{163} \mathrm{CIDH}$, Demanda ante la Corte Interamericana de Derechos Humanos, Caso Valentina Rosendo Cantú y otra Vs. México, Caso 12.579, 2 de agosto de 2009, párr. 90, y Caso Inés Fernández Ortega Vs. México, Caso 12.580, 7 de mayo de 2009, párr. 117, citados por CIDH, Caso Gladys Carol Espinoza Gonzales Vs. Perú, op. cit., párr. 190

${ }^{164}$ ColDH, Caso del Penal Miguel Castro Castro Vs. Perú, Fondo, Reparaciones y Costas. Sentencia de 25 de noviembre de 2006, párr. 310, citado por CIDH, Caso Gladys Carol Espinoza Gonzales Vs. Perú, op. cit., párr. 195

${ }_{165}$ ColDH, Caso Rosendo Cantú y otra Vs. México, Excepción Preliminar, Fondo, Reparaciones y Costas, Sentencia de 31 de agosto de 2010, párr. 109, ColDH, Caso Fernández Ortega y otros Vs. México, Fondo, Reparaciones y Costas, Sentencia de 30 de agosto de 2010, párr. 119, citado por CIDH, Caso Gladys Carol Espinoza Gonzales Vs. Perú, op. cit., párr. 195

${ }^{166}$ Tribunal Penal Internacional para la Ex Yugoslavia, Caso Furundzija, op. cit., párr. 163, citado por CIDH, Caso Gladys Carol Espinoza Gonzales Vs. Perú, op. cit., párr. 192
} 
encontraba en una situación de absoluta indefensión y bajo el control de las autoridades, por lo que Perú incumplió las obligaciones de respeto y garantía de los derechos humanos consagrados en los artículos 5.1, 5.2, 11.1 y 11.2 de la CADH, en conexión con el artículo 1.1 del mismo instrumento, así como la violación de los artículos 1 y 6 de la CIPST. $^{167}$

Es importante mencionar que la Comisión a diferencia del caso de Ana, Beatriz y Celia González Pérez Vs. México (donde sólo hace mención de la Convención Belém Do Pará), determina también la violación del artículo 7 de la Convención de Belém do Pará, en perjuicio de Gladys Carol Espinoza, ${ }^{168}$ para ello, analizó de forma delimitada las obligaciones de carácter inmediato (contraídas por el Estado de Perú) de la Convención Interamericana para Prevenir, Sancionar y Erradicar la Violencia contra las Mujeres, Convención de Belém do Pará, es decir, en palabras de la Comisión, se analizan las connotaciones especiales que tiene el deber de actuar con debida diligencia para investigar, juzgar, sancionar y reparar los daños en los casos de violencia contra las mujeres bajo el artículo 7b de la Convención de Belém do Pará. ${ }^{169}$

Para llegar a tal conclusión la CIDH emplea estándares del caso González y Otras (Campo Algodonero) Vs. México, en el sentido de que la falta de respuesta de las autoridades judiciales en torno a hechos de esa naturaleza:

“...envía el mensaje de que la violencia contra la mujer es tolerada, lo que favorece su perpetuación y la aceptación social del fenómeno, el sentimiento y la sensación de inseguridad en las mujeres, así como una persistente desconfianza de éstas en el sistema de administración de justicia." ${ }^{170}$

Así la Comisión concluye que la inacción de las autoridades peruanas de investigar las denuncias de Gladys, propiciaron un ambiente de impunidad en éste y otros tantos

\footnotetext{
${ }^{167}$ CIDH, Caso Gladys Carol Espinoza Gonzales Vs. Perú, op. cit., párr. 197-198

168 Ibídem., párr. 235

${ }^{169}$ Ibíd., párr. 221

${ }^{170}$ ColDH, Caso González y otras (“Campo Algodonero”) Vs. México, Excepción preliminar, Fondo, Reparaciones y Costas, Sentencia de 16 de noviembre de 2009, párr. 400, citado por CIDH, Caso Gladys Carol Espinoza Gonzales Vs. Perú, op. cit., párr. 226
} 
casos de tortura, violación sexual y otras formas de violencia contra la mujer, ocurridos durante el conflicto armado interno en Perú. ${ }^{171}$

\subsubsection{Análisis de los principales aportes de la resolución}

Como es de observarse, la presente resolución significa un avance importante por parte de la Comisión en la argumentación de los casos de violencia sexual. Para esta época, 2011, la Comisión emplea gran cantidad de estándares emitidos en los casos anteriores (caso Raquel Martín de Mejía y caso Ana, Beatriz y Cecilia González Pérez) y diversidad de estándares jurisprudenciales de la Corte, tanto en materia de violencia sexual, como de tortura en general, lo que enriquece el análisis de género para el encuadre de la violencia sexual como constitutiva de tortura. Asimismo, hace referencia a los precedentes jurisprudenciales del Tribunal Penal Internacional para la Ex Yugoslavia, en el caso Furundzija en torno a la violación sexual y sus finalidades asociadas a la tortura.

De lo anterior puede observarse como se nutre el Sistema Interamericano a través de las interpretaciones y estándares jurisprudenciales emitidas por el mismo Sistema, pero a su vez por los precedentes jurisprudenciales de los Tribunales ad hoc.

Podría decirse que para el año 2011 la interpretación y jurisprudencia del Sistema Interamericano ha evolucionado bastante, pues la mayoría de los estándares que utiliza la Comisión son de resoluciones y sentencias posteriores al caso de las hermanas González contra México, donde el único referente empleado era el caso de Raquel Martín de Mejía. Lo sorprendente es que durante todos estos años de resoluciones de la Comisión en materia de violencia sexual como tortura, ya existía el precedente del caso Villagrán Morales y otros Vs. Guatemala de 1999, el cual genera estándares imprescindibles para analizar y fincar la responsabilidad a los Estados por el incumplimiento de sus obligaciones en materia de derechos humanos a nivel general, y en específico con relación a la tortura, sin embargo, en ninguna de las resoluciones anteriores son empleados dichos estándares, sino hasta el presente caso.

${ }^{171} \mathrm{CIDH}$, Caso Gladys Carol Espinoza Gonzales Vs. Perú, op. cit., párr. 227 
De los estándares empleados en la resolución destaca el relacionado con los elementos exigibles para que la conducta se califique como tortura, mencionado tres elementos necesarios; que el acto sea intencional; que cause intenso sufrimiento físico y mental; y que se cometa con una finalidad. De esto puede observarse que a esta altura, la jurisprudencia interamericana exige la intencionalidad como un elemento aislado y no inmerso en la finalidad, como lo interpretó la Comisión en el caso Raquel Martín de Mejía.

Destaca también la equiparación de la incomunicación como trato cruel, inhumano y degradante, pues significa un avance en la distinción de algunos de los actos que pueden tipificarse bajo esta figura y que se distinguen de la tortura. Pero sobre todo, puede observarse que en la argumentación y determinación de responsabilidad por parte de la Comisión ya se hace referencia a la violación del artículo 5.2 de la $\mathrm{CADH}$, no como en los casos anteriores, que en su argumentación refería actos de tortura, pero determinaba responsabilidad en concreto por el derecho a la integridad personal del artículo 5 de la Convención.

Así también la Comisión determinada responsabilidad estatal por el incumplimiento de las obligaciones adquiridas mediante el artículo 7 de la Convención de Belém do Pará, lo que en los casos anteriores no sucedió, ya que sólo empleó a modo de breve análisis dicha Convención en el caso de las hermanas González, es decir en una resolución del 04 de abril de 2011. Dicho avance marca una pauta en el posicionamiento de la Comisión con la justicia de género, pues por lo menos en los casos de violencia sexual es la primera vez que finca responsabilidad a un Estado empleado el instrumento específico para la protección de los derechos humanos de las mujeres, no obstante en el caso María da Penha Fernandes Vs. Brasil del 16 de abril de 2011, la Comisión ya había fincado responsabilidad por el incumplimiento del artículo 7 de dicha Convención, dedicándole un apartado específico, es decir, a 12 días de diferencia con la recomendación del caso de las hermanas González, el nivel de posicionamiento de la 
Comisión varía a gran escala, habiendo resuelto ambos casos los mismos miembros del Organismo.

Lo anterior, sin poder asegurarlo, me parece que puede estar ligado a la necesidad de establecer estándares respecto a la responsabilidad del Estado por actos de particulares, en el contexto de la violencia contra las mujeres en el ámbito privado o familiar, materia de estudio del caso María da Penha Fernandes Vs. Brasil.

Concluyendo, me parece que hay tres etapas o momentos claves en la justicia de género por parte de la Comisión en los casos de violencia sexual contra mujeres, la primera con el caso Raquel Martín de Mejía en 1996, la segunda con el caso de las Hermanas González en 2001 y la tercera con el caso Gladys Carol Espinoza González en 2011. Tres etapas que permiten observar el avance de la justicia de género a través de la progresividad en la interpretación del Organismo, pero sobre todo a través de su posicionamiento por fincar responsabilidad empleando la Convención de Belém do Pará, lo que a su vez permite ver el reconocimiento de la importancia de dicho instrumento en la defensa de los derechos humanos de las mujeres.

La consolidación de la justicia de género por parte de la Comisión se observa en la progresividad de sus interpretaciones con relación a la violencia sexual y su acreditación como tortura; desde el reconocimiento de la violencia sexual, el valor probatorio otorgado a la declaración de las víctimas, el reconocimiento de las consecuencias de género por la violencia sexual, entre éstas el ostracismo público, la finalidad de la violencia sexual en el marco de tortura, entre otras, tal y como se fue observando en el análisis referente a cada una de las resoluciones. 


\section{Sentencias de la Corte Interamericana de Derechos Humanos}

La Corte Interamericana de Derechos Humanos fue creada en 1969 a través de la Convención Americana sobre Derechos Humanos y es el órgano jurisdiccional encargado de la supervisión de los derechos humanos y del cumplimiento de las obligaciones asumidas por los estados parte al ratificar la Convención. Sin embargo, fue hasta 1979 que se estableció la Corte.

La Corte tiene competencia para:

1. Conocer de peticiones individuales en segunda instancia, para ello el Estado tendrá que haber aceptado la competencia contenciosa de la Corte mediante el depósito del instrumento de ratificación de la Convención Americana o posteriormente;

2. Emitir medidas provisionales en casos de extrema gravedad y urgencia, para evitar daños irreparables;

3. Interpretar a través de su competencia consultiva las disposiciones de la CADH, de otros tratados de derechos humanos del Sistema Interamericano o bien, sobre la compatibilidad de las leyes internas con los instrumentos internacionales.

A través de su competencia contenciosa la Corte ha resuelto casos de violencia sexual contra mujeres como método tortura y sus pronunciamientos han creado estándares jurisprudenciales de suma importancia para la protección y defensa de los derechos humanos de las mujeres.

Al igual que la Comisión, la Corte ha avanzado en su análisis de género al resolver los casos de violaciones de derechos de las mujeres, como se observará en las sentencias que se analizarán posteriormente, relacionadas a casos de violencia sexual contra mujeres como método de tortura. 


\subsection{Caso Loayza Tamayo Vs Perú}

Sentencia de 17 de septiembre de 1997

\section{Fondo}

Los hechos sucedieron en febrero de 1993 y en mayo se presentó la denuncia ante la Comisión Interamericana de Derecho Humanos, quien el 26 de septiembre de 1994 aprobó el informe 20/94, realizando una serie de recomendaciones al Estado Peruano y declarándolo responsable por la violación al derecho a la libertad personal, a la integridad personal y las garantías judiciales. Sin embargo, el Estado no aceptó las recomendaciones, por lo que la Comisión sometió el caso a la Corte Interamericana en enero de 1995. La Corte resolvió el fondo mediante la Sentencia de 17 de septiembre de 1997.

\subsubsection{Resumen de los hechos}

El 06 de febrero de 1993 la Sra. María Elena Loayza Tamayo fue detenida por miembros de la División Nacional contra el Terrorismo (DINCOTE) de la Policía Nacional de Perú, permaneciendo detenida hasta el 26 de febrero del mismo año.

De acuerdo lo expresado en la demanda, permaneció 10 días incomunicada y fue objeto de torturas, tratos crueles y degradantes, a través de amenazas de ahogo a orillas del mar durante horas de la noche y la violación sexual por efectivos de la DINCOTE, con la finalidad de que se auto inculpara y declarara pertenecer al Partido Comunista de Perú; Sendero Luminoso (en adelante Sendero Luminoso).

\subsubsection{Sentencia de la Corte}

Cuando la Comisión concluyó el examen del caso declaró la responsabilidad de Perú, y al presentar la demanda ante la Corte, manifestó que la víctima había sido arrestada y detenida de manera arbitraria e ilegal; que se había visto sometida a torturas y a tratos inhumanos, incluidas violaciones perpetradas por agentes del Estado; y que se había conculcado el derecho de la víctima a ser oída por un juez o tribunal competente con las debidas garantías judiciales. Indicó también que se le mantuvo incomunicada durante los 
primeros 10 días de su detención y que fue sometida a torturas y tratos inhumanos para forzarla a confesar que tenía vínculos con Sendero Luminoso. ${ }^{172}$

Por su parte, la Corte con base a las pruebas que presentó la Comisión da por probado que el 06 de febrero de 1993, la Sra. Loayza Tamayo fue detenida por miembros de la DINCOTE; que del 6 al 15 de febrero estuvo incomunicada; que fue exhibida públicamente como terrorista; que durante ese periodo un médico dictaminó que presentaba equimosis; que fue procesada por el delito de traición a la patria; que se encontró privada de la libertad desde el 06 de febrero de 1993, hasta la fecha de la sentencia de la Corte; que durante la época de la detención, existió en Perú una práctica generalizada de tratos crueles, inhumanos y degradantes con motivo de las investigaciones criminales por delitos de traición a la patria y terrorismo; entre otros hechos relacionados con los procesos judiciales, militares y administrativos. Como se observa, en ningún momento da por probado los hechos relacionados con la violación sexual a la Sra. Loayza Tamayo.

Respecto a la integridad personal la Corte realiza un breve análisis en el siguiente término:

"La infracción del derecho a la integridad física y psíquica de las personas es una clase de violación que tiene diversas connotaciones de grado y que abarca desde la tortura hasta otro tipo de vejámenes o tratos crueles, inhumanos o degradantes cuyas secuelas físicas y psíquicas varían de intensidad según los factores endógenos y exógenos que deberán ser demostrados en cada situación concreta." ${ }^{173}$

Así también, profundiza a mayor medida con relación a los tratos inhumanos empleando los estándares de la Corte Europea de Derechos Humanos, en el caso Irlanda contra Reino Unido, donde concluyó que:

“...aun en la ausencia de lesiones, los sufrimientos en el plano físico y moral, acompañados de turbaciones psíquicas durante los interrogatorios, pueden ser considerados como tratos inhumanos. El carácter degradante se expresa en un

\footnotetext{
${ }_{172}$ CIDH, Informe Anual 1997, Capítulo VI. Informe sobre la Condición de la Mujer en las Américas, 1997, Apartado B.2, párr. 5

${ }^{173}$ ColDH, Caso Loayza Tamayo Vs. Perú, Sentencia de 17 de septiembre de 1997, Fondo, párr. 57
} 
sentimiento de miedo, ansia e inferioridad con el fin de humillar, degradar y de romper la resistencia física y moral de la víctima." 174

Con estos elementos de análisis y tras la revisión del expediente, la Corte concluye no dar por probada la violación sexual alegada por la Comisión. Sin embargo, respecto a la incomunicación durante la detención; la exhibición pública con un traje infamante a través de medios de comunicación; el aislamiento en celda reducida, sin ventilación ni luz natural; los golpes y otros maltratos como el ahogamiento; la intimidación por amenazas de otros actos violentos; y las restricciones al régimen de visitas, determina que constituyen formas de tratos crueles, inhumanos o degradantes conforme al artículo 5.2 de la CADH.

La Corte subraya que de las alegaciones y pruebas examinadas aparecen elementos graves, convergentes y no desvirtuados por el Estado, que permiten válidamente presumir la existencia de una práctica de tratos crueles, inhumanos y degradantes en la cual se enmarca el caso de la señora María Elena Loayza Tamayo, en violación del derecho a la integridad personal consagrado en el artículo 5 de la Convención Americana. ${ }^{175}$

Las pruebas analizadas por la Corte y relacionadas a los hechos de tortura y tratos crueles, inhumanos y degradantes ${ }^{176}$ consistían en la declaración jurada de la víctima respecto a que había sido llevada a la playa, amarrada, golpeada, desnudada y violada por los agentes estatales; cuatro testimonios de varones que habían sido detenidos por los delitos de traición a la patria y terrorismo en las mismas fechas que la Sra. Loayza Tamayo, ellos expresan que habían sido llevados a la playa, desnudados, amarrados o vendados, golpeados y torturados, donde también les ejercían prácticas de ahogamiento, todo esto con la finalidad de que firmaran su declaración inculpándose por pertenecer los actos de terrorismo (cabe destacar que el primer testigo afirma haber sido llevado a la playa junto

\footnotetext{
${ }^{174}$ Corte Europea de Derechos Humanos, Caso Irlanda Vs. Reino Unido, Sentencia del 18 de enero de 1978, párr. 167. Citado por ColDH, Caso Loayza Tamayo Vs. Perú, op. cit., párr. 57

${ }^{175}$ Ibídem., párr. 58

${ }^{176}$ Cabe destacar que la Comisión Interamericana presentó otras pruebas: copia de una serie de documentos y declaraciones relativas a los procesos acumulados contra varias personas, incluida la señora María Elena Loayza Tamayo, ante el fuero privativo militar y el fuero común, tales como dictámenes de la fiscalía, sentencias, copias de declaraciones y manifestaciones. Asimismo sometió oficios de diversas dependencias del Estado, recortes de periódico, dos vídeos, informes de varias organizaciones y algunos textos legales peruanos (véase párr. 39).
} 
a Loayza Tamayo, el segundo haber sido llevado junto a una mujer de nombre María y que escucho decir a los policías que fue violada y el tercero menciona que su hermano fue llevado también a la playa y que éste afirmó que Loayza Tamayo también fue llevada); el testimonio de dos abogados defensores, quienes declararon que existía una práctica en contra de los detenidos, donde eran llevados a la playa para ser torturados, y tres peritajes de expertos.

A pesar de la estrecha relación y coincidencia de lo declarado en los testimonios, donde se ubica que las personas detenidas eran llevadas a la playa para ser torturadas (en tres de los testimonios se puede ubicar a Loayza Tamayo en la playa y en un testimonio se corroboraba lo declarado por Loayza respecto a su violación sexual), la Corte considera que no existen elementos para acreditar la violación sexual, pasando por alto la especificidad de la violencia de género, es decir, que la violencia sexual es empleada en contra de las mujeres como un mecanismo poder y de tortura para la obtención de confesiones, a diferencia de los varones que por lo general son torturados únicamente mediante actos físicos y psicológicos.

En el mismo sentido, la Comisión Interamericana en su informe anual de 1997, refiere respecto a la no acreditación de la violación sexual como tortura por parte de la Corte, que:

"sin efectuar un examen sustancial o enunciar el tipo y carácter de las pruebas recibidas, o la carga de la prueba, la Corte procedió a indicar que no podía concluir que se hubiera probado la violación alegada atribuible a agentes del Estado."177

Con los testimonios señalados en los párrafos que anteceden, la Corte tenía elementos para acreditar la violación sexual como tortura, aunado a que había sido cometida por agentes estatales, con la intención de castigarla y obtener una confesión, y obviamente causó daños físicos y psicológicos.

\footnotetext{
${ }^{177}$ CIDH, Informe Anual 1997, Capítulo VI. Informe sobre la Condición de la Mujer en las Américas, 1997, Apartado B.2, párr. 5
} 
Finalmente, la Corte concluyó que el Estado Peruano violó el derecho a la libertad personal, a la integridad personal (en la modalidad de tratos crueles, inhumanos y degradantes) y las garantías judiciales, establecidos en los artículos 7, 5 y 8 de la CADH, respectivamente.

\subsubsection{Análisis de los principales aportes de la Sentencia}

Se considera que en el presente caso la Corte pudo haber presumido la existencia de la violación sexual a partir de la declaración jurada de la víctima y de los testimonios de los detenidos, tal como lo hizo más adelante en la sentencia del caso Penal Castro Castro Vs Perú, con relación a la inspección dactilar vaginal realizada a una de las víctimas, a partir de la declaración testimonial escrita de ésta, la cual fue presentada como prueba, ${ }^{178}$ hecho que como se observa en el análisis del caso correspondiente fue tipificado por la Corte como violencia sexual constitutiva de tortura.

Al igual que la evolución que se observó en la Comisión, en este primer caso de la Corte no le otorga pleno valor probatorio a la declaración de la víctima, lo que dadas las circunstancias de detención, incomunicación y tratos crueles acreditados, daban por sentada la existencia de la violación sexual como práctica para obtener confesiones en el caso de las mujeres y como práctica sistemática comprobada en las época en Perú, todo esto fortalecido con los testimonios de los testigos, pudieron haber sido elementos suficientemente sólidos para que la Corte determinara la existencia de la violencia sexual y su nexo con la tortura.

Un aporte importante de la sentencia es la ejemplificación de ciertos actos que pueden ser considerados tratos crueles, inhumanos o degradantes; la incomunicación, la exhibición pública con traje infamante en los medios de comunicación, el aislamiento en celda reducida, sin ventilación ni luz natural, la intimidación por amenazas de otros actos violentos y la restricción al régimen de visitas. De esta forma se van consolidando los

\footnotetext{
${ }^{178}$ CoIDH, Caso Penal Castro Castro Vs. Perú, Sentencia de 25 de noviembre de 2006, Fondo, Reparaciones y Costas, párr. 197.50
} 
estándares jurisprudenciales del Sistema Interamericano, que permiten diferenciar la tortura de los tratos crueles, inhumanos o degradantes.

Sin embargo, en materia de análisis de género no se observa el esfuerzo de la Corte. Tampoco se hace alusión alguna a la Convención Interamericana para Prevenir, Sancionar y Erradicar la Violencia contra la Mujer, a pesar de estar en vigor desde 1995 y haber sido ratificada por Perú el 02 de abril de 1996.

\subsection{Caso Penal Castro Castro Vs. Perú}

\section{Sentencia de 25 de noviembre de 2006}

Fondo, Reparaciones y Costas

Los hechos del presente caso sucedieron del 6 al 9 de mayo de 1992 al interior del Penal Castro Castro. El 18 de mayo de 1992, se sometió la petición a la Comisión Interamericana y el 5 de marzo de 2001 la Comisión aprobó el Informe № 43/01, mediante el cual declaró admisible la petición.

El 23 de octubre de 2003, la Comisión de conformidad con el artículo 50 de la Convención aprobó el Informe № 94/03, en el cual concluyó que el Estado es responsable por la violación del derecho a la vida, a la integridad personal, a las garantías judiciales y la protección judicial, donde realizó una serie de recomendaciones a efectos de prevenir y garantizar los derechos humanos. Informe que le fue notificado al Estado el 09 de enero de 2004, otorgándole el plazo de dos meses para informar sobre las medidas adoptadas. El Estado solicitó tres prórrogas a la Comisión para dar cumplimiento a las recomendaciones, mismas que fueron concedidas, dándosele como último término el 09 de agosto de 2004. El 5 de agosto de 2004 el Estado remitió el informe, sin embargo, ante la falta de implementación satisfactoria de las recomendaciones contenidas en el informe 94/03, la Comisión decidió someter el asunto a la Corte el 09 de septiembre del mismo año. 
La Corte emitió sentencia sobre fondo, reparaciones y costas, el 25 de noviembre de 2006.

\subsubsection{Resumen de los hechos}

Los hechos tienen origen el 6 de mayo de 1992, mediante la ejecución del "Operativo Mudanza 1" en el interior del Penal Miguel Castro Castro, donde el Estado produjo la muerte de al menos 42 personas internas, hirió a 175 y sometió a trato cruel, inhumano y degradante a otras 322 .

Los hechos también se refieren a las torturas, requisas y aislamiento experimentado por las presuntas víctimas con posterioridad al operativo y durante los traslados de las personas internas a otros penales de Perú, así como a las condiciones "infrahumanas" en que se encontraban las presuntas víctimas en los centros a los que fueron trasladadas.

El "Operativo Mudanza 1" tenía por objeto trasladar a las internas que se encontraban en el pabellón 1A del Penal Miguel Castro Castro (aproximadamente 135 internas mujeres) a otra cárcel de máxima seguridad de mujeres. Asimismo, el operativo se dirigió contra el pabellón 4B de dicho penal, en el que había aproximadamente 400 varones. Las personas internas en esos pabellones se encontraban acusadas o sentenciadas por los delitos de terrorismo o traición a la patria y eran presuntamente miembros de Sendero Luminoso.

\subsubsection{Sentencia de la Corte}

La Corte para analizar los hechos de violencia contra las mujeres, relaciona los alcances del derecho a la integridad personal (artículo 5 de la CADH) tomando como referencia de interpretación las disposiciones de la Convención Belém do Pará y CEDAW, estableciendo que ambos instrumentos complementan el corpus juris internacional en materia de protección de la integridad personal de las mujeres. ${ }^{179}$

\footnotetext{
${ }^{179}$ Ibídem., párr. 276
} 
La Corte parte del estudio de la violación al derecho a la integridad establecido en el artículo 5 de la $\mathrm{CADH}$ en relación con el artículo 1.1 de la misma, y en conexión a los artículos 1, 6 y 8 de la Convención Interamericana para Prevenir y Sancionar la Tortura, analizando cuatro momentos en que sucedieron los hechos violatorios a los derechos humanos de las personas internas, siendo estos:

1) La violación a la integridad personal como consecuencia del "Operativo Mudanza $1^{\prime \prime}$

En este apartado la Corte hace referencia al uso ilegítimo de la fuerza, la magnitud de la fuerza utilizada, el tipo de armas, explosivos y gases empleados contra las personas internas en los pabellones $1 \mathrm{~A}$ y $4 \mathrm{~B}$ del Penal, las heridas por las balas, explosiones, gases, esquirlas, granadas, bombas y la caída de escombros durante los cuatro días que duró el ataque, aunado a los sufrimientos adicionales en el curso de esos cuatro días (privación de alimentos, agua, luz y atención médica).

Respecto a la situación específica de las mujeres, la Corte refiere que el ataque inició contra el pabellón de mujeres $1 \mathrm{~A}$ del Penal, por lo que las internas se vieron obligadas a huir del ataque en dirección al pabellón 4B, arrastrándose pegadas al piso y pasando por encima de los cuerpos de personas fallecidas para evitar ser alcanzadas por las balas. Resultando particularmente grave en el caso de las mujeres embarazadas quienes se arrastraron sobre su vientre.

Para tipificar las amenazas constantes y el peligro real al que se encontraban sometidas las internas como constitutivas de tortura psicológica, la Corte empleó jurisprudencia emitida en casos anteriores, en el siguiente sentido:

“...la mera amenaza de que ocurra una conducta prohibida por el artículo 5 de la Convención Americana, cuando sea suficientemente real e inminente, puede constituir en sí misma una transgresión a la norma de que se trata. Para determinar la violación al artículo 5 de la Convención, debe tomarse en cuenta no sólo el 
sufrimiento físico sino también la angustia psíquica y moral. La amenaza de sufrir una grave lesión física puede llegar a configurar una "tortura psicológica."180

Con tal análisis y con las conclusiones de los peritajes la Corte estimó que las internas experimentaron tortura psicológica por las amenazas constantes y el peligro real que generaron las acciones estatales que podían producir su muerte y serias lesiones a su integridad física, concluyendo que las mujeres embarazadas experimentaron un sufrimiento psicológico adicional, ya que además de haber visto lesionada su propia integridad física, padecieron sentimientos de angustia, desesperación y miedo por el peligro que corrían la vida de sus hijos.

La Corte relaciona la falta de protección estatal con lo establecido en el artículo 7a de la Convención de Belém do Pará, en el sentido de que los Estados deben velar porque las autoridades y agentes estatales se abstengan de cualquier acción o práctica de violencia contra las mujeres.

Finalmente, la Corte concluye que el Estado es responsable de la violación a la integridad física de las internas que resultaron heridas, lo cual constituyó una violación al artículo 5 de la CADH, y que el conjunto de actos de agresión y las condiciones en que el Estado puso deliberadamente a las internas, causando en todas ellas un grave sufrimiento psicológico y emocional, constituyó una tortura psicológica violatoria de los artículos 5.1 y 5.2 de la Convención Americana; 1, 6 y 8 de la Convención Interamericana para Prevenir y Sancionar la Tortura, violación que se vio agravada en el caso de las mujeres embarazadas, de forma tal que los actos de violencia les afectaron en mayor medida. Asimismo en el caso específico de una de las internas que falleció durante el operativo, la Corte determinó que el Estado era responsable de actos de tortura, toda vez que el cadáver presentaba signos visibles de tortura, lo que evidenció la muestra de violencia extrema con la que actuaron los agentes estatales. ${ }^{181}$

\footnotetext{
${ }^{180}$ ColDH, Caso Baldeón García Vs. Perú, Sentencia del 06 de abril de 2006, párr. 119, ColDH, Caso Tibi Vs. Ecuador, Sentencia del 07 de septiembre de 2004, párr. 147 y ColDH, Caso 19 Comerciantes Vs. Colombia, Sentencia del 5 de julio de 2004, párr. 149, citados por ColDH, Caso Penal Castro Castro Vs. Perú, op. cit., párr. 279

${ }^{181}$ ColDH, Caso Penal Castro Castro Vs. Perú, op. cit., párr. 293
} 
2) Los tratos recibidos con posterioridad al 9 de mayo de 1992 y durante los traslados a otros penales y a los hospitales.

En este apartado la Corte se refiere a las condiciones infrahumanas en que permanecieron la mayoría de las personas internas; el momento en que el ex Presidente del Perú (Alberto Fujimori) caminó entre los internos tendidos boca abajo en el suelo de los patios del penal; a los que estaban heridos y fueron mantenidos en las zonas del penal conocidas como "tierra de nadie" y "admisión", sin recibir atención médica; y a una minoría de internos heridos que durante el traslado al Hospital de la Sanidad de la Policía fueron hacinados y golpeados, entre otras condiciones que generaron nuevas violaciones a la integridad física, psíquica y moral.

En lo específico a las internas hace referencia a las condiciones de las mujeres embarazadas, donde los agentes estatales no tuvieron ninguna consideración respecto a su condición específica, considerando que resultó particularmente grave que tuvieran que permanecer en posición boca abajo y que el presenciar este trato generó mayor angustia entre las demás personas internas ${ }^{182}$.

Respecto a estos hechos, la Corte concluyó que:

"... los tratos constituyeron un tratamiento inhumano violatorio del artículo 5 de la Convención Americana. Esta violación se vio agravada respecto de aquellos internos que se encontraban heridos y respecto de las mujeres que se encontraban embarazadas. "183

3) Los tratos recibidos en los centros de salud a los que fueron trasladadas las personas internas durante el ataque o una vez terminado éste.

En este apartado la Corte hace referencia a las personas internas que fueron trasladados al Hospital de la Policía y que no recibieron tratamiento médico adecuado, dando lugar a

\footnotetext{
${ }^{182}$ Ibídem., párr. 298

${ }^{183}$ Ibídem., párr. 300
} 
padecimientos crónicos al no ser atendidas las lesiones, concluyendo que la falta de atención ocasionó a las personas internas sufrimiento psicológico y físico adicional. Asimismo refiere que dentro de los tratos recibidos las personas internas fueron desnudadas y obligadas a permanecer sin ropa durante casi todo el tiempo que estuvieron en el hospital, en algunos casos se prolongó durante varios días y en otros durante semanas, encontrándose siempre vigiladas por agentes armados. ${ }^{184}$

Con relación a la situación de las mujeres detenidas, la Corte empleó estándares internacionales del Sistema de Naciones Unidas respecto al tratamiento que deben recibir las mujeres detenidas o arrestadas, que establecen que:

“... las detenidas deben ser supervisadas y revisadas por oficiales femeninas y las mujeres embarazadas y en lactancia deben ser proveídas con condiciones especiales durante su detención". 185

"... la discriminación [hacía las mujeres] incluye la violencia basada en el sexo, "es decir, la violencia dirigida contra la mujer porque es mujer o que la afecta en forma desproporcionada", [y abarca] "actos que infligen daños o sufrimientos de índole física, mental o sexual, amenazas de cometer esos actos, coacción y otras formas de privación de la libertad. "186

En un principio la Corte analizó la desnudez forzada a la cual fueron sometidas las personas internas heridas como un trato violatorio a su dignidad personal. Sin embargo, en el caso de seis mujeres consideró que la desnudez forzada tuvo características especialmente graves, pues no se les permitió asearse y para utilizar el sanitario debían hacerlo acompañadas de un guardia armado, quien no les permitía cerrar la puerta y les apuntaba con el arma mientras hacían sus necesidades fisiológicas. Estas características

\footnotetext{
${ }^{184}$ Ibíd., párr. 301, 302, 304

${ }^{185}$ ONU, Reglas mínimas para el tratamiento de los reclusos, Adoptadas por el Primer Congreso de las Naciones Unidas sobre Prevención del Delito y Tratamiento del Delincuente, celebrado en Ginebra en 1955, y aprobadas por el Consejo Económico y Social en sus resoluciones 663C (XXIV) de 31 de julio de 1957 y 2076 (LXII) de 13 de mayo de 1977, párr. 23 y 53, citado por CoIDH, Caso Penal Castro Castro Vs. Perú, op. cit., párr. 303

${ }^{186}$ ONU, Comité para la Eliminación de la Discriminación contra la Mujer, 11 período de sesiones. Recomendación general 19 "La violencia contra la mujer". Doc. HRI/GEN/1/Rev. 1at84 (1994), párr. 6, citado por ColDH, Caso Penal Castro Castro Vs. Perú, op. cit., párr. 303
} 
especiales permitieron a la Corte analizar la desnudez forzada como un acto de violencia sexual capaz de ser estudiado como constitutiva de tratos crueles, en el siguiente sentido:

“... esas mujeres, además de recibir un trato violatorio de su dignidad personal, también fueron víctimas de violencia sexual, ya que estuvieron desnudas y cubiertas con tan solo una sábana, estando rodeadas de hombres armados, quienes aparentemente eran miembros de las fuerzas de seguridad del Estado. Lo que califica este tratamiento de violencia sexual es que las mujeres fueron constantemente observadas por hombres."187

Para acreditar la violencia sexual, la Corte empleó los estándares internacionales emitidos por la Corte Penal Internacional para Ruanda, en el caso Akayesu, respecto a que la violencia sexual se configura con acciones de naturaleza sexual que se cometen en una persona sin su consentimiento, que además de comprender la invasión física del cuerpo humano, pueden incluir actos que no involucren penetración o incluso contacto físico alguno. ${ }^{188}$ De esta forma, la Corte dejó claro que la violencia sexual no requiere para su configuración requisitos específicos como la penetración o el contacto físico, extinguiendo así la necesidad de acreditar estos elementos, estableciendo que existen actos de naturaleza sexual que comprenden la invasión del cuerpo, aun cuando no exista contacto físico, como la desnudez forzada.

Con estos elementos la Corte concluyó que el permanecer en el hospital vigiladas por hombres armados, en un estado precario de salud, constituyó violencia sexual que les produjo constante temor ante la posibilidad de que la violencia se extremara aún más, lo que les ocasionó grave sufrimiento psicológico y moral, aunado al sufrimiento físico que ya estaban padeciendo a causa de sus heridas y determinó que el Estado es responsable por la violación al derecho a la integridad personal consagrado en el artículo 5.2 de la

\footnotetext{
${ }^{187}$ ColDH, Caso Penal Castro Castro Vs. Perú, op. cit., párr. 306

${ }^{188}$ Tribunal Penal Internacional para Ruanda, Caso Akayesu, op. cit., párr. 688, citado por ColDH, Caso Penal Castro Castro Vs. Perú, op. cit. párr. 306
} 
Convención Americana, en perjuicio de las seis internas que sufrieron esos tratos crueles. $^{189}$

\subsubsection{La violencia sexual como tortura}

Más adelante el Tribunal analiza los actos cometidos contra una interna que fue trasladada al Hospital de la Sanidad de la Policía y sometida con suma brusquedad a una inspección vaginal dactilar por varias personas encapuchadas a la vez, bajo el pretexto de revisarla, donde consideró, siguiendo criterios jurisprudenciales del Derecho Penal Internacional y el Derecho Penal comparado que:

"... la violación sexual no implica necesariamente una relación sexual sin consentimiento, por vía vaginal, como se consideró tradicionalmente. Por violación sexual también debe entenderse actos de penetración vaginales o anales, sin consentimiento de la víctima, mediante la utilización de otras partes del cuerpo del agresor u objetos, así como la penetración bucal mediante el miembro viril."190

Lo anterior es reforzado con criterios establecidos en la jurisprudencia de la Corte Europea de Derechos Humanos en el caso Aydin vs Turquía, en el siguiente sentido:

“... la violación sexual de una detenida por un agente del Estado es un acto especialmente grave y reprobable, tomando en cuenta la vulnerabilidad de la víctima y el abuso de poder que despliega el agente. [Además la violación] causa gran daño físico y psicológico que deja a la víctima "humillada física y emocionalmente", situación difícilmente superable por el paso del tiempo, a diferencia de lo que acontece en otras experiencias traumáticas. ${ }^{191}$

Con estos estándares y con base a lo establecido en el artículo 2 de la Convención Interamericana para Prevenir y Sancionar la Tortura, concluye que los actos de violencia sexual a que fue sometida la interna (inspección vaginal dactilar) constituyeron una

\footnotetext{
${ }^{189}$ ColDH, Caso Penal Castro Castro Vs. Perú, op. cit., párr. 308

${ }^{190}$ Ibídem., párr. 310

${ }^{191}$ Corte Europea de Derechos Humanos, Caso Aydin Vs. Turquía, Sentencia del 25 de septiembre de 1997, párr. 83, citado por ColDH, Caso Penal Castro Castro Vs. Perú, op. cit., párr. 311
} 
violación sexual que por sus efectos constituyen tortura. Y por tanto, declaró al Estado responsable por la violación del derecho a la integridad personal consagrado en el artículo 5.2 de la Convención Americana, así como por la violación de los artículos 1, 6 y 8 de la Convención Interamericana para Prevenir y Sancionar la Tortura.

4) Las condiciones generales de detención a las que fueron sometidos las personas internas con posterioridad al "Operativo Mudanza 1".

En este apartado la Corte analiza las graves condiciones de detención de hombres y mujeres, respecto a las últimas consistentes en:

"Las internas trasladadas a las cárceles de "Santa Mónica de Chorrillos" y de "Cristo Rey de Cachiche" fueron objeto de constantes maltratos físicos y psicológicos. Fueron mantenidas sin contacto con el mundo exterior, ni acceso a libros, televisión, radios o periódicos. No se les permitía dialogar entre sí, leer o estudiar, ni realizar trabajos manuales de ningún tipo, ni siquiera aquellos que trataban de realizar con hilos tomados de sus propias ropas, con migas de pan o con restos de "valvas de choro" que venían en la sopa. La violación de cualquiera de estas prohibiciones era motivo de golpizas. Tampoco tenían acceso a materiales de aseo personal, tales como jabón, papel higiénico, toallas sanitarias, ni ropa íntima para cambiarse, así como ropa de abrigo. Permanecían encerradas 23 horas y media o 24 horas del día en una celda de dos metros por dos metros, la cual compartían al menos dos personas. Dichas celdas no tenían acceso a luz de ningún tipo, natural o artificial, por lo que permanecían en una oscuridad constante. Los alimentos eran escasos. Eran objeto de constantes requisas, durante las cuales recibían golpes, puntapiés, choques eléctricos, golpes en la planta de los pies con varillas, les arrojaban agua y las amenazaban con matarlas. Asimismo, si se negaban a cantar el himno nacional eran castigadas." 192

\footnotetext{
${ }^{192}$ CoIDH, Caso Penal Castro Castro Vs. Perú, op. cit., párr. 197.51 y 319
} 
La Corte hace especial hincapié en el daño y sufrimiento experimentado por las mujeres en general y en especial las mujeres embarazadas y las madres, por la desatención de las necesidades fisiológicas, la incomunicación en las internas madres y la desatención de necesidades básicas de salud pre natal y post natal.

Respecto a las internas madres establece que la incomunicación severa con sus hijos les ocasionó un sufrimiento psicológico adicional y que los Estados tienen la obligación de "tomar en consideración la atención especial que deben recibir las mujeres por razones de maternidad, lo cual implica, entre otras medidas, asegurar que se lleven a cabo visitas apropiadas entre madre e hijo."193

En cuanto a la desatención de las necesidades fisiológicas de las mujeres detenidas, la Corte retoma las reglas mínimas para el tratamiento de los reclusos, en el sentido de que en los Centros de detención las condiciones sanitarias deben ser adecuadas para mantener la higiene y la salud, permitiéndoles acceso regular a retretes, a que se bañen y limpien su ropa regularmente, así como realizar arreglos especiales para las detenidas en período menstrual, embarazadas, o acompañadas por sus hijos. ${ }^{194}$ De esta forma la Corte concluye que la comisión de esos excesos les causó sufrimiento especial y adicional a las mujeres internas.

En el caso de dos internas, la Corte refirió que el Estado desatendió respecto a la primera las necesidades básicas de salud pre natal y en cuanto a la segunda no se le brindó atención médica post natal, determinando que tales omisiones implicaron una violación adicional a la integridad personal de éstas. ${ }^{195}$

Con estos elementos de análisis la Corte determinó que, tanto las condiciones de detención como el tratamiento al que fueron sometidas las internas, constituyó tortura física y psicológica, lo que implicó violación a los artículos 5.2 de la Convención Americana y 1, 6 y 8 de la Convención Interamericana para Prevenir y Sancionar la Tortura.

\footnotetext{
${ }^{193}$ Ibídem., párr. 330

${ }^{194}$ ONU, Reglas mínimas para el tratamiento de los reclusos, op. cit., párr. 15-19 y 23, citado por ColDH, Caso Penal Castro Castro Vs. Perú, op. cit., párr. 331

${ }^{195}$ CoIDH, Caso Penal Castro Castro Vs. Perú, op. cit., párr. 332
} 
Asimismo, es importante mencionar que la Corte determinó la violación de los artículos 8.1 y 25 de la Convención no sólo con relación a la obligación del artículo 1.1 de la misma, sino también en conexión del artículo 7b de la Convención Interamericana para Prevenir, Sancionar y Erradicar la Violencia contra la Mujer y los artículos 1, 6 y 8 de la Convención Interamericana para Prevenir y Sancionar la Tortura, en perjuicio de los familiares de las víctimas fallecidas, por la falta de acceso a la justicia y por no actuar con la debida diligencia para investigar, sancionar y reparar. Siendo así el primer fallo de la Corte en que se responsabiliza a un estado por el incumplimiento de las obligaciones contraídas en la convención de Belém Do Pará.

\subsubsection{Análisis de los principales aportes de la sentencia}

El presente fallo comparado con el anterior, significa un avance sustancial en la jurisprudencia de la Corte. En éste, la Corte interpreta los dos instrumentos de protección a los derechos humanos de las mujeres; CEDAW y Belén do Pará, lo que refleja el reconocimiento por parte del Sistema Interamericano de la importancia de ambos instrumentos que son considerados la Carta de los Derechos Humanos de las Mujeres, pues como se ha observado en muchos de los casos que preceden, a pesar de la existencia de ambos tratados, éstos no eran empleados para la argumentación de los casos, utilizándose únicamente la CADH y en ocasiones la Convención Interamericana para Prevenir y Sancionar la Tortura.

Asimismo refuerza los estándares empleados para tipificar tortura psicológica en casos de varones, aplicándolos al caso concreto de las mujeres internas, debido al peligro y amenazas constantes al que estaban sometidas, agravándolo en el caso de las mujeres embarazadas por el doble sufrimiento en relación al peligro de la vida de sus hijos. Interpretación en la cual la Corte toma en cuenta las características específicas de las víctimas, ligadas a su condición sexual, pero sobretodo otorgando una protección especial, generando así un estándar basado en la protección del derecho a la igualdad a partir de las diferencias. 
Destaca también el precedente que asienta la Corte con relación a las condiciones en que tuvieron a las mujeres embarazadas, sin recibir atención médica y tiradas en el suelo boca abajo, lo que encuadró como tratamiento inhumano. Con tal precedente se siguen reforzando los estándares para distinguir los actos que constituyan tratos inhumanos, pero también se observa el análisis que toma en cuenta las características particulares de las víctimas y sus necesidades específicas, como en el caso de las mujeres embarazadas, donde no da un enfoque totalitarista, y lo considera un hecho agravado por su condición.

Otro aporte significativo es la acreditación de la desnudez forzada como violencia sexual y constitutiva de tratos crueles, lo que ostenta el control y acceso sobre el cuerpo de las mujeres como mecanismo de poder, sin necesidad de contacto físico. De esta forma, siguiendo la línea de interpretación del Tribunal Penal Internacional para Ruanda en el caso Akayesu, la Corte se posiciona sobre la base de que la violencia sexual no requiere para su configuración de requisitos como la penetración o contacto físico, concluyendo que existen actos de naturaleza sexual que constituyen la invasión del cuerpo de las mujeres. Con ello puede observarse como el Sistema Interamericano sigue nutriéndose a través de los precedentes de los Tribunales ad hoc, haciendo suyas y ampliando sus interpretaciones para extender el ámbito de protección de los derechos humanos de las mujeres, lo que a todas luces favorece al principio de progresividad de los derechos humanos.

Llama la atención también la equiparación de la inspección vaginal dactilar como violación sexual constitutiva de tortura, bajo el criterio de que la violación no sólo se lleva a cabo mediante una relación sexual vaginal como se había considerado tradicionalmente.

Así también respecto a las condiciones de detención de las mujeres internas y la desatención de las necesidades fisiológicas de las mujeres en general y particularmente de las embarazadas, por la desatención de la salud pre natal y post natal, aunado a la incomunicación, la Corte al analizar las reglas mínimas para el tratamiento de los reclusos, toma en cuenta las necesidades específicas de las mujeres por razón de sus sexo, como la necesidad de arreglos especiales por el periodo menstrual, por el embarazo o por el 
acompañamiento de los hijos, concluyendo que tales desatenciones causaron un sufrimiento especial y adicional, lo que en conjunto encuadró como tortura física y psicológica en contraposición al artículo 5.2 de la CADH.

De todo lo anterior puede observarse que el presente fallo es un precedente de suma importancia para la defensa de los derechos de las mujeres en casos de violencia sexual, pues la Corte genera parámetros para distinguir distintos tipos de violencia a los que pueden ser sometidas las mujeres y su respectivo encuadre como tortura física o psicológica, o bien como tratos crueles, inhumanos o degradantes. Estos estándares pueden ser empleados en la interpretación y fundamentación de casos similares en el ámbito interno de los países, para reforzar el ámbito de protección de los derechos de las mujeres y buscar la adecuada tipificación como actos constitutivos de tortura o tratos crueles, inhumanos o degradantes, y no sólo como actos asilados de violencia sexual.

Por último, es importante mencionar que la presente sentencia es la primera en donde se responsabiliza a un Estado por el incumplimiento de sus obligaciones contraídas a través de la Convención Belém do Pará, en específico por violación al artículo 7b de la misma.

\subsection{Caso González y Otras “Campo Algodonero" Vs. México}

Sentencia de 16 de noviembre de 2009

\section{Excepción preliminar, Fondo, Reparaciones y Costas}

Los hechos del presente caso tienen origen en noviembre de 2001 cuando son encontrados los cuerpos de las víctimas.

La petición inicial se presentó ante la Comisión el 06 de marzo de 2002, quien en febrero de 2005 declaró la admisibilidad de las peticiones mediante los informes No. 16/05, 17/05 y 18/05 (por tratarse de tres víctimas), en enero de 2007 notificó a las partes la decisión de acumular los tres casos y en marzo de 2007 aprobó el informe de fondo No. 28/07 en que realizó recomendaciones al Estado. 
Sin embargo, la Comisión decidió someter el caso ante la Corte tras considerar que el Estado no había adoptado sus recomendaciones, presentando la demanda en noviembre de 2007. Posteriormente la Corte dictó sentencia contra México el 16 de noviembre de 2009, en la cual resolvió excepciones preliminares, fondo, reparaciones y costas.

\subsubsection{Resumen de los hechos}

El caso se refiere a los feminicidios de tres mujeres (Claudia Ivette González, Esmeralda Herrera Monreal y Laura Berenice Ramos Monárrez) en Ciudad Juárez, Chihuahua, México. Los cuerpos fueron encontrados en un campo algodonero el 06 de noviembre de 2001.

La demanda hace referencia a la responsabilidad internacional del Estado de México por la falta de medidas de protección a las víctimas y la falta de prevención, pese al pleno conocimiento de la existencia de un patrón de violencia de género que había dejado centenares de mujeres y niñas asesinadas, así como la responsabilidad por la falta de debida diligencia en la investigación y la denegación de justicia.

La Corte comienza por analizar las violaciones a derechos humanos alegadas por la Comisión, entre estas, el derecho a la vida, la integridad personal, la libertad personal, las garantías judiciales, los derechos del niño(a) y la protección judicial, con relación a la obligación de respeto y garantía de los derechos establecida en el artículo 1.1 de la CADH y la obligación de adoptar disposiciones de derecho interno establecida en el artículo 2 del mismo instrumento, así como las obligaciones de carácter inmediato establecidas en el artículo 7 de la Convención Interamericana para Prevenir, Sancionar y Erradicar la Violencia contra las Mujeres.

Asimismo, para analizar la posible atribución de los hechos violatorios al Estado, consideró prioritario analizar el contexto y las condiciones en que se desarrollaron los hechos, para lo cual examinó las siguientes situaciones: 


\subsubsection{El contexto general de Ciudad Juárez}

En cuanto al contexto general de Ciudad Juárez refiere entre otras características, que se trata de una ciudad industrial donde prevalece la industria maquiladora y el tránsito de migrantes mexicanos y extranjeros por su cercanía a la frontera internacional, así como convergencia de diversos factores ${ }^{196}$ que han incrementado la inseguridad y violencia, como son la desigualdad social, la delincuencia organizada, el narcotráfico, la trata de personas, el tráfico de armas y el lavado de dinero.

\subsubsection{El fenómeno de homicidios de mujeres y las cifras}

En este rubro la Corte retoma lo informado y documentado respecto a las desapariciones y homicidios de mujeres en Ciudad Juárez desde 1993, por diversos organismos nacionales e internacionales de protección de los derechos humanos, así como por las organizaciones no gubernamentales de carácter nacional e internacional, estableciendo que no existen datos claros sobre la cifra exacta de homicidios de mujeres desde 1993.

En este sentido, la $\mathrm{CIDH}$, el Comité CEDAW, la Comisión Nacional de los Derechos Humanos y Amnistía Internacional indican cifras que oscilan entre 260 y 370 mujeres entre 1993 y 2003, mientras que el Estado reportó que hasta el año 2001 se habían registrado 264 homicidios; hasta el año 2003, 328 homicidios y para el 2005, 379 homicidios. Por su parte, el Observatorio Ciudadano refiere que de acuerdo a la información aportada por la Comisionada para Prevenir y Erradicar la Violencia contra las Mujeres, de la Secretaría de Gobernación, se habla de 442 mujeres asesinadas.

Ante estos datos la Corte finalmente establece que no existen conclusiones convincentes en cuanto a las cifras aportadas, pero observa que de cualquier forma son alarmantes y que más allá de los números, los alegatos de las partes y las pruebas aportadas apuntan a un fenómeno complejo (aceptado por el Estado en el reconocimiento parcial de responsabilidad) de violencia contra las mujeres desde el año 1993.

\footnotetext{
${ }^{196}$ Esta serie de factores han sido documentado por diversos informes nacionales e internacionales, como son los informes producidos por el Comité para la Eliminación de todas las formas de Discriminación hacia la Mujer, CEDAW, informes de la Relatora Especial sobre Violencia contra la Mujer, sus causas y consecuencias, Informes de Amnistía Internacional, de la Comisión Nacional de Derechos Humanos en México, entre otros.
} 


\subsubsection{Características de las víctimas}

De acuerdo a lo alegado por la Comisión y los representantes se observó que las víctimas eran mujeres jóvenes de 15 a 25 años de edad, estudiantes o trabajadoras de maquilas o de tiendas u otras empresas locales y que algunas vivían en Ciudad Juárez desde hacía relativamente poco tiempo.

\subsubsection{La modalidad de los homicidios}

La Corte retomó lo alegado por la Comisión en el sentido de que considerable número de homicidios presentaron signos de violencia sexual. El Estado por su parte, alegó que según cifras del año 2004, cerca del 26 \% de los homicidios obedecían a actos de índole sexual violento.

Asimismo señaló los informes de organismos gubernamentales y no gubernamentales que refieren factores en común en varios de los homicidios, donde las mujeres son secuestradas y mantenidas en cautiverio y luego de días o meses sus cadáveres son encontrados en terrenos baldíos, con signos de violencia, incluyendo violación u otros tipos de abusos sexuales, tortura y mutilaciones. Entre éstos, CEDAW y Amnistía Internacional coincidieron en que alrededor de un tercio de los homicidios tenían un componente de violencia sexual o características similares.

\subsubsection{La violencia basada en género}

Referente a la violencia de género, la Corte hace reseña a una serie factores generadores de violencia mencionados por el Estado, como el que los homicidios se encontraban influenciados por una cultura de discriminación contra la mujer (aunque éstos tienen causas diversas, con diferentes autores, en circunstancias muy distintas y con patrones criminales diferenciados); la modificación de roles familiares generados por la vida laboral de las mujeres, como un factor estructural que creó la violencia contra las mismas; y la falta de servicios públicos básicos en las zonas marginadas, entre otros factores ya mencionados en el contexto general de Ciudad Juárez. 
Así también el Estado presentó pruebas de que en los homicidios a mujeres ocurridos durante 1993 y 2005, el 31.4\% ocurrió por violencia social, el 28\% por violencia doméstica, el $20.6 \%$ por algún móvil sexual y el $20.1 \%$ indeterminados.

En este último aspecto la Corte hace notar las inconsistencias en las cifras del Estado, pues en su respuesta al informe del CEDAW del 2003, señaló que 66\% de los homicidios eran resultado de la violencia familiar o doméstica, el $8 \%$ por móvil desconocido y $26 \%$ por actos de índole sexual violento. Sin embargo, concluye que de acuerdo a los distintos informes de los organismos nacionales e internacionales, muchos casos tratan de violencia de género en un contexto de discriminación sistemática contra la mujer, independientemente de que coincidan en que los motivos y los perpetradores son diversos.

\subsubsection{El alegado feminicidio}

En este aspecto la Corte hace referencia a las diversas calificaciones que se da a los homicidios por parte de distintos actores, por ejemplo, la Comisión no califica los hechos como feminicidio, los representantes hacen referencia a los feminicidios como una forma extrema de violencia contra las mujeres y de máxima expresión de la violencia misógina, el Estado en la audiencia pública empleó el término feminicidio, sin embargo, en las observaciones que realizó a los peritajes presentados por los representantes objetó el hecho de que pretendieran incluir este término como un tipo penal, cuando no existía en la legislación nacional e internacional, por su parte, los peritos, dependencias gubernamentales, organizaciones no gubernamentales y amicus curiae se refieren a feminicidios.

Así, la Corte decidió emplear el término homicidios de mujeres por razones de género, también conocido como feminicidio, estableciendo que no es posible pronunciarse de manera definitiva sobre cuales homicidios de mujeres en el presente caso son por razones de género. 


\subsubsection{La investigación de los homicidios de mujeres}

En lo que refiere a las investigaciones y de acuerdo a lo alegado por la Comisión y los representantes, la Corte menciona que la falta de esclarecimiento y las irregularidades en las investigaciones respectivas generaron un clima de impunidad, siendo esta circunstancia un factor más que caracterizó los homicidios.

Asimismo, con base a la pruebas presentadas por diversos organismos nacionales e internacionales, la Corte señaló como parte de las irregularidades en las investigaciones la demora en la iniciación de las investigaciones, la lentitud e inactividad en los expedientes, la negligencia e irregularidades en la recolección y realización de pruebas e identificación de víctimas, la pérdida de información, el extravío de piezas de los cuerpos bajo custodia del Ministerio Público y la falta de contemplación de la violencia contra las mujeres como parte de un fenómeno global de violencia de género.

Por otro lado hace referencia a un alarmante patrón de respuesta y concepciones estereotipadas de las mujeres desaparecidas, donde las autoridades en un principio se negaban a investigar las desapariciones reportadas de mujeres, pues su actuación se basaba en prejuicios de género estereotipados, donde culpaban a las mujeres de su suerte, ya sea por su forma de vestir, el lugar donde trabajaban, su conducta, el andar solas o por la falta de cuidado de sus padres

El Estado por su parte señaló en su informe presentado al CEDAW que la cultura de discriminación de la mujer contribuyó a que los homicidios no fueran percibidos como un problema importante, que requería de acciones inmediatas y contundentes por parte de las autoridades. La Comisión refiere que la falta de respuesta o esclarecimiento de las autoridades era notablemente deficiente y que gran parte de los asesinatos seguían impunes para el 2002. Y los representantes alegaron que a ocho años de sucedidos los hechos del presente caso, la situación de impunidad no había tenido mejora alguna. 
El Estado en cambio, señaló que no existió una situación de impunidad, ya que se ha investigado, perseguido, capturado, enjuiciado y sancionado a un número significativo de responsables.

Por su parte los informes de los organismos, refieren una situación de impunidad generalizada, donde también las penas impuestas a los agresores se enmarcan en un promedio no mayor de 15 años de prisión, a pesar de que en la mayoría se cometieron con agravantes y que la pena impuesta era más baja cuando se trataba de homicidios de mujeres, con características sexuales.

Es de observar, la última reflexión de la Corte, referente al informe de la Comisión Interamericana, sobre la Situación de los Derechos de las Mujer en Ciudad Juárez, donde señala que la impunidad está relacionada con la discriminación contra la mujer, y que la impunidad confirma que la violencia y discriminación ejercida contras las mujeres es aceptable, lo cual fomenta su perpetuación.

Con el análisis de los elementos anteriores, la Corte concluye que desde 1993 existe en Ciudad Juárez un aumento de homicidios de mujeres y que más allá de las cifras donde no existe firmeza, es preocupante los altos grados de violencia que presentan algunos de estos crímenes, incluyendo la sexual. Que éstos han sido influenciados por una cultura de discriminación contra la mujer, lo cual ha incidido tanto en los motivos y modalidad, como en la respuesta de la autoridad. Destacando que la respuesta ineficiente y actitudes indiferentes en la investigación parecen haber permitido la perpetuación de la violencia contra la mujer en Ciudad Juárez. Así también constata que hasta el 2005, la mayoría de los crímenes seguía sin ser esclarecido, siendo los homicidios con características de violencia sexual los que presentan el mayor grado de impunidad. 


\subsubsection{Sentencia de la Corte}

En el presente caso, la Corte concluye que las tres mujeres fueron víctimas de violencia contra la mujer, según la CADH y la Convención de Belém do Pará, considerando que los homicidios fueron por razones de género y están enmarcados en un contexto de violencia contra la mujer en Ciudad Juárez. ${ }^{197}$ Sin embargo no hace referencia alguna a la tortura a la que fueron sometidas las víctimas, ya que los cuerpos (como se mencionó en el apartado sobre la modalidad de los homicidios) presentaban signos visibles de violencia sexual y tortura.

Posteriormente la Corte entra en análisis para determinar si la violencia perpetrada contra las mujeres, que acabo con sus vidas, es atribuible al Estado, a partir del deber de respeto, garantía y no discriminación del derecho a la vida, a la integridad, libertad y acceso a la justicia, conforme al derecho a las garantías judiciales y protección judicial.

En cuanto a la obligación de respeto (abstención de violar derechos) y ante la falta de pruebas aportadas por la Comisión y los representantes, que acrediten la participación de agentes estatales, la Corte determina que no se puede atribuir al Estado esta responsabilidad, pues independientemente de que la impunidad del caso impida conocer si los perpetradores fueron agentes estatales o particulares actuando con su apoyo y tolerancia, el tribunal no puede presumir que sí lo fueron y condenar automáticamente al Estado por el incumplimiento de la obligación de respeto, consagrada en el artículo 1.1 de la $\mathrm{CADH} .{ }^{198}$

Al analizar la obligación de garantía (art. 1.1 CADH) con relación al derecho a la vida de las mujeres (art. $4 \mathrm{CADH}$ ), la Corte observa con base a la jurisprudencia en el caso "Niños de la Calle" Vs. Guatemala que el derecho a la vida no sólo implica la privación arbitraria de ésta, sino la adopción de medidas necesarias para proteger y preservar la vida. ${ }^{199}$

\footnotetext{
${ }^{197}$ ColDH, Caso González y Otras “Campo algodonero” Vs. México, Sentencia del 16 de noviembre de 2009, Excepción preliminar, fondo, reparaciones y costas, párr. 231

${ }^{198}$ Ibídem., párr. 242

${ }^{199}$ ColDH, Caso de los "Niños de la Calle" (Villagrán Morales y otros) Vs. Guatemala, Sentencia de 19 de noviembre de 1999, párr. 114, citado por ColDH, Caso González y Otras "Campo algodonero" Vs. México, op. cit., párr. 245
} 
Asimismo refiere que tal obligación con relación al derecho a la vida, a la integridad personal, incluida la tortura y el derecho a la libertad personal implica el deber del estado de prevenir, investigar y sancionar a los responsables. En este sentido resalta lo aludido por la Corte con relación al artículo 5 de la CADH (integridad personal), al referir que la obligación de garantizar tal derecho, implica el deber del Estado de prevenir e investigar posibles actos de tortura $u$ otros tratos crueles, inhumanos o degradantes, ${ }^{200}$ ya que tal aseveración permite presumir que la Corte podrá pronunciarse sobre el incumplimiento de la obligación de garantía por parte del Estado respecto a la tortura a la que fueron sometidas las víctimas, sin embargo, la Corte no distingue desde este momento si se refiere a actos de tortura, o bien a otros tratos crueles, inhumanos o degradantes, ya que lo aborda de forma indiferenciada.

Con tales estándares la Corte entra al estudio del caso en cuanto a la prevención, investigación y sanción de la violación al derecho a la vida, a la integridad personal y a la libertad, a través del feminicidio de las mujeres en Ciudad Juárez y recuerda con base a unos de sus primeros casos contenciosos que el deber de prevención abarca:

“...todas aquellas medidas de carácter jurídico, político, administrativo y cultural que promuevan la salvaguarda de los derechos humanos y que aseguren que las eventuales violaciones a los mismos sean efectivamente consideradas y tratadas como un hecho ilícito que, como tal, es susceptible de acarrear sanciones para quien las cometa, así como la obligación de indemnizar a las víctimas por sus consecuencias perjudiciales. Es claro, a su vez, que la obligación de prevenir es de medio o comportamiento y no se demuestra su incumplimiento por el mero hecho de que un derecho haya sido violado."201

Posteriormente analiza como la Convención de Belém do Pará; la Recomendación General No. 19 del Comité CEDW; la Declaración sobre la Eliminación de la Violencia contra la Mujer de la ONU; la Relatoría Especial sobre violencia contra la mujer de la ONU y la

\footnotetext{
${ }^{200}$ CoIDH, Caso González y Otras “Campo algodonero" Vs. México, op. cit., párr. 246

${ }^{201}$ ColDH, Caso Velásquez Rodríguez Vs. Honduras, op. cit., párr. 166
} 
Comisión Interamericana de Derechos Humanos en el caso Maria Da Penha Vs. Brasil han determinado la obligación de los estados de actuar con la debida diligencia para prevenir, investigar y sancionar la violencia contra la mujer, sea ésta perpetrada por particulares o agentes estatales. De igual forma observa las directrices ${ }^{202}$ sobre las medidas que deben tomar los Estados para cumplir con sus obligaciones internacionales de debida diligencia en la prevención, establecidas por la Relatoría Especial sobre la violencia contra la mujer de la ONU.

Con tales elementos y a efectos de analizar las medidas adoptadas por el Estado en el presente caso, la Corte determina la obligación de los Estados de:

“...adoptar medidas integrales para cumplir con la debida diligencia en casos de violencia contra las mujeres. En particular, deben contar con un adecuado marco jurídico de protección, con una aplicación efectiva del mismo y con políticas de prevención y prácticas que permitan actuar de una manera eficaz ante las denuncias. La estrategia de prevención debe ser integral, es decir, debe prevenir los factores de riesgo y a la vez fortalecer las instituciones para que puedan proporcionar una respuesta efectiva a los casos de violencia contra la mujer. Asimismo, los Estados deben adoptar medidas preventivas en casos específicos en los que es evidente que determinadas mujeres y niñas pueden ser víctimas de violencia. Todo esto debe tomar en cuenta que en casos de violencia contra la mujer, los Estados tienen, además de las obligaciones genéricas contenidas en la Convención Americana, una obligación reforzada a partir de la Convención Belém do Pará."203

\footnotetext{
${ }^{202}$ Consistentes en la ratificación de los instrumentos internacionales de derechos humanos; garantías constitucionales sobre la igualdad de la mujer; existencia de leyes nacionales y sanciones administrativas que proporcionen reparación adecuada a las mujeres víctimas de la violencia; políticas o planes de acción que se ocupen de la cuestión de la violencia contra la mujer; sensibilización del sistema de justicia penal y la policía en cuanto a cuestiones de género, accesibilidad y disponibilidad de servicios de apoyo; existencia de medidas para aumentar la sensibilización y modificar las políticas discriminatorias en la esfera de la educación y en los medios de información, y reunión de datos y elaboración de estadísticas sobre la violencia contra la mujer. En: ONU, La violencia contra la mujer en la familia: Informe de la Sra. Radhika Coomaraswamy, Relatora Especial sobre la violencia contra la mujer, con inclusión de sus causas y consecuencias, UN Doc. E/CN.4/1999/68, 10 de marzo de 1999, párr. 25

${ }^{203} \mathrm{CoIDH}$, Caso González y Otras “Campo algodonero" Vs. México, op. cit. párr. 258
} 
De esta forma analizó lo alegado por la Comisión, los representantes y el Estado, respecto a este último observó la adopción de disposiciones legislativas y la creación de instancias, como la Fiscalía Especial para la Investigación de Homicidios de Mujeres. Sin embargo, de acuerdo a los informes nacionales e internacionales ${ }^{204}$ que evidencian que la respuesta del Estado frente a los homicidios de mujeres ha sido ineficaz e insuficiente, la Corte estipula que el Estado tenía pleno conocimiento desde 1998 del riesgo que corrían las mujeres de ser objeto de violencia y no demostró haber adoptado medidas efectivas de prevención antes de noviembre de 2001 que redujeran los factores de riesgo para las mujeres, así como tampoco demostró que la creación de instancias y adiciones legislativas fueran suficientes y efectivas para prevenir las graves manifestaciones de violencia contra la mujer en el estado de Chihuahua.

Para fijar la responsabilidad del Estado respecto al incumplimiento de la obligación de garantía y en específico su deber de prevención, la Corte determina con base a su jurisprudencia que:

“...es claro que un Estado no puede ser responsable por cualquier violación de derechos humanos cometida entre particulares dentro de su jurisdicción. En efecto, las obligaciones convencionales de garantía a cargo de los Estados no implican una responsabilidad ilimitada de los Estados frente a cualquier acto o hecho de particulares, pues sus deberes de adoptar medidas de prevención y protección de los particulares en sus relaciones entre sí se encuentran condicionados al conocimiento de una situación de riesgo real e inmediato para un individuo o grupo de individuos determinado y a las posibilidades razonables de prevenir o evitar ese riesgo. Es decir, aunque un acto u omisión de un particular tenga como consecuencia jurídica la violación de determinados derechos humanos de otro particular, aquél no es

\footnotetext{
${ }^{204}$ Véase CIDH, Situación de los Derechos de la Mujer en Ciudad Juárez, México: El Derecho a No Ser Objeto de Violencia y Discriminación, OEA/Ser.L/V//II.117, 7 de marzo de 2003; ONU, Informe de México producido por el Comité para la eliminación de la Discriminación a la mujer, CEDAW/C/2005/OP.8/MEXICO, 27 de enero de 2005; ONU, Informe de la Relatora Especial sobre la violencia contra la mujer, sus causas y consecuencias, Yakin Ertürk, Integración de los Derechos Humanos de la Mujer y la Perspectiva de Género: La Violencia contra la Mujer, Misión a México, E/CN.4/2006/61/Add.4, 13 de enero de 2006; Amnistía Internacional, México: Muertes intolerables, Diez años de desapariciones y asesinatos de mujeres en Ciudad Juárez y Chihuahua, AMR 41/027/2003; Comisión Nacional de los Derechos Humanos, Informe Especial sobre los Casos de Homicidios y Desapariciones de Mujeres en el Municipio de Juárez, Chihuahua, 2003 y; Comisión Nacional de los Derechos Humanos, Recomendación 44/1998 emitida el 15 de mayo de 1998
} 
automáticamente atribuible al Estado, pues debe atenderse a las circunstancias particulares del caso y a la concreción de dichas obligaciones de garantía."205

Con las pruebas y los estándares jurisprudenciales aportados, la Corte para determinar la responsabilidad estatal, analizó el deber de prevención desde dos momentos; antes de la desaparición de las víctimas y antes de la localización de sus cuerpos sin vida.

En el primer momento a pesar de considerar que la falta de prevención de la desaparición no conlleva per se la responsabilidad internacional del Estado, ya que éste no tenía conocimiento de un riesgo real e inmediato para las víctimas, el contexto del caso sí implicaba una responsabilidad de protección reforzada para las mujeres de Ciudad Juárez, por la situación de vulnerabilidad. Así la ausencia de una política desde 1998 (cuando se recomendó la adopción de medidas por parte de la Comisión Nacional de los Derechos Humanos, para hacer frente al patrón de violencia), implicó que la Corte determinara el incumplimiento por parte del Estado de su obligación de prevención.

En cuanto al segundo momento, la Corte refiere que el Estado tenía conocimiento de la existencia de un riesgo real e inmediato de que las víctimas fueran agredidas sexualmente, sometidas a vejámenes y asesinadas, y por tanto consideró que:

"...ante tal contexto surge un deber de debida diligencia estricta frente a denuncias de desaparición de mujeres, respecto a su búsqueda durante las primeras horas y los primeros días. Esta obligación de medio, al ser más estricta, exige la realización exhaustiva de actividades de búsqueda. En particular, es imprescindible la actuación pronta e inmediata de las autoridades policiales, fiscales y judiciales ordenando medidas oportunas y necesarias dirigidas a la determinación del paradero de las víctimas o el lugar donde puedan encontrarse privadas de libertad. Deben existir procedimientos adecuados para las denuncias y que éstas conlleven una investigación efectiva desde las primeras horas. Las autoridades deben presumir que

\footnotetext{
${ }^{205}$ ColDH, Caso de la Masacre de Pueblo Bello Vs. Colombia, Sentencia de 31 de enero de 2006, Fondo, Reparaciones y Costas, párr. 123; ColDH, Caso Comunidad Indígena Sawhoyamaxa Vs Paraguay, Sentencia de 29 de marzo de 2006, Fondo, Reparaciones y Costas, párr. 155 y ColDH, Caso Valle Jaramillo y otros Vs. Colombia, Sentencia de 27 de noviembre de 2008, párr. 78, citados por ColDH, Caso González y Otras "Campo algodonero" Vs. México, op. cit., párr.280
} 
la persona desaparecida está privada de libertad y sigue con vida hasta que se ponga fin a la incertidumbre sobre la suerte que ha corrido."206

Y determina que México no demostró haber adoptado medidas razonables para encontrar a las víctimas con vida, no actuó con prontitud dentro de las primera horas y días posteriores a la denuncias de desaparición. Así también las actitudes de los funcionarios con los familiares de las víctimas dieron a entender que las denuncias no debían ser tratadas con urgencia, aunado a las demoras injustificadas. De esta forma concluyó que el Estado no actuó con la debida diligencia para prevenir adecuadamente las muertes y agresiones a las mujeres y que tal incumplimiento del deber de garantía es particularmente serio debido al contexto conocido por el Estado y a las obligaciones reforzadas impuestas por el artículo 7b de la convención de Belém do Pará. ${ }^{207}$

En este sentido destaca que la Corte ya no hace referencia a la tortura u otros tratos crueles, inhumanos o degradantes, simplemente se refiere a "vejámenes" y "agresiones", las cuales pareciera que encuadran en mayor medida con los tratos crueles, inhumanos y degradantes, más no con la tortura, es decir, la Corte baja de tono su análisis, vacilando así en su pronunciamiento.

Por otro lado, establece que México tampoco adoptó medidas de derecho interno conforme al artículo 2 de la CADH y 7c de la Convención de Belém do Pará, con la finalidad de dar una respuesta inmediata y eficaz ante las denuncias y que las autoridades tuvieran la capacidad y sensibilidad para actuar ante la gravedad del fenómeno de violencia contra las mujeres.

Por ello, concluye la violación del derecho a la vida, la integridad personal y la libertad personal reconocidos en los artículos 4.1, 5.1, 5.2 y 7.1 de la CADH, en relación a la obligación de garantía y la obligación de adoptar disposiciones de derechos interno, así como las obligaciones contempladas en el artículo $7 \mathrm{~b}$ y $7 \mathrm{c}$ de la Convención de Belém do Pará.

\footnotetext{
${ }^{206}$ CoIDH, Caso González y Otras “Campo algodonero" Vs. México, op. cit., párr. 283

${ }^{207}$ Ibídem., párr. 284
} 
Cabe destacar que de la determinación de responsabilidad estatal que antecede, la Corte hace mención de la violación al artículo 5.2 de la $\mathrm{CADH}$, es decir, la prohibición a ser sometido a tortura ni a penas o tratos crueles, inhumanos o degradantes. Sin embargo, no aclara si se refiere a actos de tortura o a otros tratos crueles, inhumanos o degradantes, aunque por la forma en la que fue disminuyendo el impacto de los actos refiriéndose únicamente a vejámenes o agresiones y de acuerdo al voto concurrente de la Jueza Cecilia Medina Quiroga, deja claro que hace referencia a los segundos, aunque más bien pareciera que la Corte intencionalmente no quiso pronunciarse al respecto, colocando en la ambigüedad su pronunciamiento.

Tal ambigüedad se reitera en la determinación respecto al deber de investigar en el marco de la garantía de los derechos humanos, pues tras analizar las diversas irregularidades y dilación ${ }^{208}$ en la que recayó el Estado mediante la investigación, la Corte concluye que:

“...el Estado incumplió con su deber de investigar -y con ello su deber de garantizarlos derechos consagrados en los artículos 4.1, 5.1, 5.2 y 7.1 de la Convención Americana, en relación con los artículos 1.1 y 2 de la misma y con el artículo 7.b y 7.c de la Convención Belém do Pará, en perjuicio de Claudia Ivette González, Laura Berenice Ramos Monárrez y Esmeralda Herrera Monreal. Por los mismos motivos, el Estado violó los derechos de acceso a la justicia y protección judicial, consagrados en los artículos 8.1 y 25.1 de la Convención Americana, en relación con los artículos 1.1 y 2 de la misma y 7.b y 7.c de la Convención Belém do Pará, en perjuicio de los familiares de las tres víctimas..."

Del análisis previo se desprende la responsabilidad del Estado por incumplir con su obligación de garantía respecto a los tratos crueles, inhumanos o degradantes a los que fueron sometidas las víctimas, incluidos en éstos, la violencia sexual.

\footnotetext{
${ }^{208}$ Las irregularidades en la custodia de la escena del crimen, recolección y manejo de evidencias, elaboración de las autopsias y en la identificación y entrega de los restos de las víctimas; irregularidades en la actuación seguida contra presuntos responsables y alegada fabricación de culpables; irregularidades en la fragmentación de las investigaciones; demora injustificada e inexistencia de avances sustanciales en las investigaciones; y la falta de sanción a los funcionarios públicos involucrados con irregularidades la investigación de los feminicidios. Véase CoIDH, Caso González y Otras “Campo algodonero" Vs. México, op. cit., párr. 287- 386

${ }^{209}$ ColDH, Caso González y Otras "Campo algodonero" Vs. México, op. cit., párr. 389
} 
Por lo anterior, estimo que la presente sentencia debió haber sido pronunciada en el sentido en que lo hace la entonces Jueza Cecilia Medina Quiroga en su voto concurrente, quien a mi parecer aplica las normas de interpretación y el principio pro homine al equiparar los actos cometidos contra las víctimas como tortura, ya que el artículo 16 de la Convención Interamericana para Prevenir y Sancionar la Tortura deja a salvo lo dispuesto por la CADH y por otras convenciones sobre la materia, lo que nos remite a las normas de interpretación establecidas en el artículo 29 de la Convención Americana, en el sentido de que ninguna disposición de tal convención, en este caso la prohibición de la tortura (art. 5.2), puede ser interpretada para limitar el goce y ejercicio de cualquier derecho reconocido en leyes internas o en otras convenciones en que sea parte el Estado.

El voto razonado refiere que la Corte consideró la no responsabilidad estatal por actos de tortura, porque no había prueba de que ésta hubiera sido perpetrada por agentes estatales o que éstos pudiendo impedir el acto no lo hicieron ${ }^{210}$ y para contrarrestar tal supuesto la Jueza emplea diversos estándares que pudieron haberse empleado para decretar responsabilidad internacional por tortura, dentro de los que destacan los siguientes:

"La finalidad de las disposiciones del artículo 7 del Pacto Internacional de Derechos Civiles y Políticos es proteger la dignidad y la integridad física y mental de la persona. El Estado Parte tiene el deber de brindar a toda persona, mediante medidas legislativas y de otra índole, la protección necesaria contra los actos prohibidos por el artículo 7, sean infligidos por personas que actúen en el desempeño de sus funciones oficiales, al margen de dichas funciones o incluso a título privado. "211

“...cuando las autoridades del Estado [...] tienen conocimiento o motivos fundados para creer que sujetos privados o actores no estatales perpetran actos de tortura o malos tratos y no ejercen la debida diligencia para impedir, investigar, enjuiciar y

\footnotetext{
${ }^{210} \mathrm{CoIDH}$, Caso González y Otras “Campo algodonero” Vs. México, op. cit, Voto Concurrente de la Jueza Cecilia Medina Quiroga en relación con la sentencia, párr.9

${ }^{211}$ ONU, Comité de Derechos Humanos, Observación general No. 20, Artículo 7, 44o período de sesiones (1992), párr. 2, citado por ColDH, Caso González y Otras "Campo algodonero" Vs. México, op. cit, Voto Concurrente de la Jueza Cecilia Medina Quiroga en relación con la sentencia, párr. 5
} 
castigar a dichos sujetos privados o actores no estatales [...] el Estado es responsable [...] por consentir o tolerar esos actos inaceptables. La negligencia del Estado a la hora de intervenir para poner fin a esos actos, sancionar a los autores y ofrecer reparación a las víctimas de la tortura facilita y hace posible que los actores no estatales cometan impunemente actos prohibidos por la Convención, por lo que la indiferencia o inacción del Estado constituye una forma de incitación y/o de autorización de hecho. El Comité ha aplicado este principio a los casos en que los Estados Partes no han impedido actos de violencia de género, como la violación, la violencia en el hogar, la mutilación genital femenina o la trata, o no han protegido a las víctimas." 212

Aunado a lo anterior, la Jueza Cecilia Medina sigue avanzando en su análisis al establecer que el concepto de tortura de la Corte, no debe ser necesariamente igual al de las Convenciones contra la Tortura del Sistema Interamericano y de la ONU, ni ineludiblemente aplicado, ya que la CADH se encuentra vigente desde 1978 y no contiene una definición del concepto, mismo que debió ser construido por el Tribunal en el marco de su facultad para interpretar el alcance protección de las disposiciones de la Convención y que no todos los Estados partes de la CADH lo son de la Convención Interamericana para Prevenir y Sancionar la Tortura, por lo que la Corte puede encontrarse en una situación en la que deba conocer un caso de tortura sin poder aplicar dicha Convención.

Para sustentar lo anterior retoma los estándares emitidos por el Tribunal Penal Internacional de la ex Yugoslavia en el siguiente sentido:

"El Tribunal para la Ex-Yugoslavia, después de examinar el conjunto de normas y reglas que se refieren a la tortura, llega, por una parte, a la conclusión, que comparto, de que hay tres elementos en la tortura que no son objetados y que constituyen, por consiguiente, jus cogens: i) el sufrimiento o dolor severos, físicos o mentales, ya sea por acción u omisión; ii) la intencionalidad del acto y iii) la

\footnotetext{
${ }^{212}$ ONU, Comité contra la tortura, Observación General No. 2 sobre aplicación del artículo 2 por los Estados Partes, CAT/C/GC/2, 24 de enero de 2008, párr. 18, citado por ColDH, Caso González y Otras “Campo algodonero" Vs. México, op. cit, Voto Concurrente de la Jueza Cecilia Medina Quiroga en relación con la sentencia, párr. 10
} 
motivación o fin del acto para conseguir algo. Por otra parte, hay tres elementos que permanecen en contienda y, por lo tanto, no forman parte del jus cogens: i) la lista de motivaciones por las cuales el acto se comete; ii) la necesidad de que el acto se cometa en conexión con un conflicto armado; y iii) el requisito de que el acto sea perpetrado o sea instigado por un agente del Estado o se realice con su consentimiento o aquiescencia." ${ }^{213}$

Con los argumentos anteriores la Jueza sostiene que la Corte no está obligada a aplicar o guiarse de la definición de la CIPST ni la Convención contra la tortura, debiendo prevalecer el jus cogens, toda vez que otorga una protección más amplia a las víctimas, y que si bien la Corte es independiente para definir la tortura, no necesita integrar el elemento de la participación por acción u omisión de agentes estatales, sino más bien analizar la atribución del incumplimiento de la obligación de garantía al Estado, respecto a la integridad de las víctimas frente a la tortura, lo cual estaba acreditado en el momento en que el Estado tuvo conocimiento de la existencia de un riesgo real e inmediato de que las víctimas fueran agredidas sexualmente, sometidas a vejámenes y asesinas desde el momento que desaparecieron. Tal y como lo reconoció la Corte en el presente fallo.

Y concluye:

"Si la Corte hubiera concluido que el Estado era en este caso responsable de la tortura a la que fueron sometidas las víctimas, el Tribunal hubiera seguido la tendencia de otros órganos de supervisión internacionales, ya citados, que han venido instituyendo una tendencia en cuanto a la responsabilidad de los Estados por actos de tortura cometidos por agentes no estatales, lo que, estimo, hubiera constituido un importante desarrollo y aclaración de un tema sobre el cual la Corte con certeza deberá seguir ocupándose."214

\footnotetext{
${ }^{213}$ Tribunal Penal Internacional para la Ex Yugoslavia, Caso Dragoljub Kunarac, Radomir Kovac y Zoran Vukovic, op. cit., párr. 483-484, citado por ColDH, Caso González y Otras "Campo algodonero" Vs. México, op. cit, Voto Concurrente de la Jueza Cecilia Medina Quiroga en relación con la sentencia, párr. 15

${ }^{214}$ ColDH, Caso González y Otras “Campo algodonero" Vs. México, op. cit, Voto Concurrente de la Jueza Cecilia Medina Quiroga en relación con la sentencia, párr. 20
} 
Por último, otro aspecto a destacar (de forma general al no ser objeto de estudio de la presente investigación) en el presente fallo, es que la Corte al considerar que la violencia contra la mujer constituyó una forma de discriminación, puntualizó la violación por parte del Estado de su deber de no discriminación, con relación a la obligación de garantía de los derechos consagrados en los artículos 4.1, 5.1, 5.2 y 7.1, así como en relación con el acceso a la justicia consagrado en los artículos 8.1 y 25.1 de la $\mathrm{CADH}$, en perjuicio de los familiares de las víctimas. Asimismo determinó la violación del artículo 19 de la CADH (derechos del niño(a)), en relación con los artículos 1.1 y 2 de dicho tratado, en perjuicio de dos de las víctimas menores de edad.

\subsubsection{Análisis de los principales aportes de la sentencia}

La presente sentencia es un precedente de suma importancia, por un lado, al tratarse de responsabilidad estatal por actos de particulares y por el otro, al versar sobre la máxima expresión de la violencia de género y misógina contra mujeres; los feminicidios.

Sin embargo, en lo que respecta a la configuración de la violencia sexual contra mujeres como constitutiva de tortura, la Corte va bajando de tono su análisis respecto a la obligación de garantía del Estado, refiriéndose primero a la obligación de prevenir e investigar indistintamente posibles actos de tortura $u$ otros tratos crueles, inhumanos o degradantes, más adelante refiriéndose a agresiones sexuales, vejámenes y asesinatos, y por último concluyendo la responsabilidad por dicho incumplimiento con relación a las muertes y agresiones, es decir, como ya se mencionó en apartados anteriores, la Corte baja de tono su análisis y pareciera que voluntariamente no desea pronunciarse de forma clara y literal sobre el encuadre de tales actos como tortura, o como tratos crueles, inhumanos o degradantes, determinando la violación al artículo 5.1 y 5.2 de la CADH, sin especificar bajo cuál de las dos figuras contempladas en el artículo 5.2.

La forma en que fue disminuyendo la figura en la que encuadra la violencia sexual y la tortura alegada; agresiones, permite observar la intención de la Corte por encuadrarlas tácitamente como tratos crueles, inhumanos y degradantes. Lo que se concluye al 
observar la inexistencia del análisis de los elementos que configuran la tortura y el voto concurrente de la entonces Jueza Cecilia Medina.

En este sentido, considero que la Corte pudo haber ido más allá y tipificar dichas agresiones sexuales y mutilaciones como tortura, pues de los estándares emitidos en sentencias anteriores, ha quedado claro que para ello se requieren los siguientes elementos: la intencionalidad, la finalidad, los daños físicos y mentales y su comisión ya sea por agentes estatales (que ordenen, instiguen, induzcan a su comisión, lo cometan directamente o que, pudiendo impedirlo, no lo hagan) o por personas bajo instigación de los primeros. $\mathrm{Y}$ en el presente caso los tres primeros elementos se encontraban corroborados y el cuarto pudo haberse equiparado al momento en que los agentes estatales no impidieron tales actos, pues la Corte ya se había pronunciado al analizar en el marco de la obligación de garantía el deber de prevención (antes de la localización de los cuerpos sin vida) e investigación, en el sentido de que el Estado tenía conocimiento de la existencia de un riesgo real e inmediato de que las víctimas fueran agredidas sexualmente, sometidas a vejámenes y asesinadas, y no adoptó medidas para prevenir tales actos desde 1993 hasta 2005.

Haberse pronunciado en este sentido, hubiera permitido la evolución de los estándares jurisprudenciales vinculados a la tortura por aquiescencia del Estado, generando un precedente histórico. No obstante, no pasa desapercibido el alto análisis de género en la presente sentencia al analizarse el contexto y las condiciones en que se desarrollaron los hechos, donde la Corte reconoce que los homicidios estaban influenciados por una cultura de discriminación sistemática contra la mujer, influenciada por la modificación de los roles familiares debido a la vida laboral de las mujeres.

Asimismo, esta sentencia es una más en donde se responsabiliza a un Estado por el incumplimiento de las obligaciones contraídas por la Convención Belém do Pará, lo que aunado a la resolución en el caso Penal Castro Castro, va consolidando la utilización por parte del Sistema Interamericano de los instrumentos específicos de protección de los derechos humanos de las mujeres. 
Por último, es importante destacar que el voto concurrente de la entonces Jueza Cecilia Medina deja un precedente histórico para la futura discusión y evolución de la configuración de la tortura mediante la aquiescencia del Estado.

\subsection{Caso Inés Fernández Ortega y otros Vs. México}

Sentencia de 30 de agosto de 2010

\section{Excepción preliminar, Fondo, Reparaciones y Costas}

Este caso es el tercero ${ }^{215}$ que conoce el Sistema Interamericano por actos de violencia sexual contra mujeres perpetrado por Militares en México y el segundo cometido en el estado de Guerrero. Los hechos suceden en marzo de 2002 y en junio de 2004 después de una serie de irregularidades por parte de las autoridades competentes se presenta la petición ante la Comisión Interamericana por la detención ilegal, violación y tortura en agravio de Inés Fernández. En octubre de 2006, casi dos años después, la Comisión declara el informe de admisibilidad No. 94/06.

El 30 de octubre de 2008, la Comisión aprobó el informe de fondo 89/08, realizando una serie de recomendaciones al Estado y concediéndole un plazo de dos meses para informar sobre las acciones implementadas en el cumplimiento de las recomendaciones, pero el Estado solicitó una prórroga de doce meses para la presentación del informe, concediéndosele tres meses. Posteriormente el Estado rindió el informe respectivo al cumplimiento de las recomendaciones, sin embargo, la Comisión tomando en consideración la falta de avances sustantivos en el efectivo cumplimiento decidió someter el caso a la Corte.

Finalmente, el 07 de mayo de 2009, la Comisión presentó el caso a la Corte haciendo referencia entre otros temas a la violación y tortura, la falta de debida diligencia en la

\footnotetext{
${ }^{215}$ Independientemente de que la Sentencia de la Corte en el presente caso fue emitida con anterioridad a la sentencia del caso Valentina Rosendo Cantú Vs. México, los hechos de este último sucedieron con un mes de antelación y la petición fue presentada con anterioridad a la Comisión Interamericana.
} 
investigación y sanción de los responsables de los hechos, la falta de reparación adecuada en favor de la víctima y sus familiares, la utilización del fuero militar para la investigación y juzgamiento de violaciones a los derechos humanos y las dificultades que enfrentan las personas indígenas, en particular las mujeres, para acceder a la justicia y a los servicios de salud. $^{216}$

El 30 de agosto de 2010 la Corte Interamericana dictó Sentencia determinando la responsabilidad del Estado por violaciones a la integridad personal, la dignidad, la vida privada, el derecho a no ser objeto de injerencias arbitrarias o abusivas en el domicilio, las garantías judiciales y la protección judicial en perjuicio de Inés Fernández Ortega.

\subsubsection{Resumen de los hechos}

De acuerdo al informe de admisibilidad de la CIDH de fecha 21 de octubre de 2006, el 22 de marzo de 2002, Inés Fernández Ortega, de 29 años de edad, se encontraba en el interior de su domicilio cuando tres soldados se introdujeron sin su consentimiento, mientras que nueve soldados se quedaron en su patio. Los soldados que entraron al domicilio le preguntaron sobre la ubicación de su marido y sobre la carne que tenía en su patio, al no contestar y permanecer en silencio por no hablar español, los soldados se enfurecieron y seguidamente la amenazaron con sus armas ordenándole que se tirara al suelo y la violentaron sexualmente. ${ }^{217}$

Al igual que en el caso de Valentina Rosendo, la averiguación previa de Inés fue remitida al Fuero Militar para la investigación de los hechos y sanción de los responsables, pasándose por alto de nueva cuenta los estándares internacionales emitidos en la materia, violando así la imparcialidad e independencia con la que el Juez debe de conocer e investigar los asuntos de su competencia.

El proceso legal en el caso de Inés fue muy similar al de Valentina, Inés presentó su denuncia penal el 24 de marzo de 2002, en Ayutla de los Libres, Guerrero, realizándose

\footnotetext{
${ }^{216} \mathrm{CIDH}$, demanda ante la Corte Interamericana de Derechos Humanos en el caso Inés Fernández Ortega y Otra (Caso 12.580) contra los Estados Unidos Mexicanos, 07 de mayo de 2009, párr. 1 y 2

${ }^{217} \mathrm{CIDH}$, Informe de Admisibilidad № 94/06, Petición 540/04, Inés Fernández Ortega y otros Vs México, párr. 7-8
} 
por parte del Ministerio Público las primeras diligencias para la integración de la averiguación previa, sin embargo el 17 de mayo del mismo año, el Ministerio Público se declaró incompetente, remitiendo el caso ante el Fuero Militar. Ante esta situación, Inés presentó un escrito ante el Ministerio Público Militar solicitándole se abstuviera de conocer del asunto por ser inconstitucional la competencia militar, dado que la presunta agraviada era una civil, sin embargo dicha autoridad le notificó que era competente para conocer el mismo.

Posteriormente se agotaron una serie de recursos, como lo fue el amparo solicitando la inconstitucionalidad de la competencia del fuero militar, declarándose éste improcedente por el Juez Primero de Distrito de Chilpancingo, Guerrero, ante dicha decisión se interpuso el recurso de revisión de amparo, donde se confirmó la improcedencia del mismo. ${ }^{218}$

\subsubsection{Sentencia de la Corte}

Desde el momento en que la Corte comenzó por examinar las pruebas del presente caso puede observarse el contenido de análisis de género en sus determinaciones, pues en un primer momento la Corte entra al estudio de las prueba de la violación sexual a la señora Inés Fernández Ortega y es ahí donde fija un estándar de suma importancia en materia de violencia sexual contra mujeres, relacionado en cierta forma a la prohibición de exigir pruebas gráficas y documentales en este tipo de agresiones, por tratarse de un delito de comisión oculta, en el siguiente sentido:

“...para la Corte es evidente que la violación sexual es un tipo particular de agresión que, en general, se caracteriza por producirse en ausencia de otras personas más allá de la víctima y el agresor o los agresores. Dada la naturaleza de esta forma de violencia, no se puede esperar la existencia de pruebas gráficas o documentales y,

\footnotetext{
${ }^{218}$ Ibídem, párr. 9-11
} 
por ello, la declaración de la víctima constituye una prueba fundamental sobre el hecho." 219

La Corte tras considerar probado que Inés Fernández fue sujeta a violencia sexual por parte de agentes militares, parte por analizar la misma como constitutiva de tortura. Previo de llegar a ello, y tras las afirmaciones del Estado, en el sentido de que no se acreditaba la violación sexual y que el examen ginecológico no presentaba datos de agresión, es que la Corte observa lo ya establecido por la jurisprudencia internacional en el sentido de que:

"...el uso de la fuerza no puede considerarse un elemento imprescindible para castigar conductas sexuales no consentidas, así como tampoco debe exigirse prueba de la existencia de resistencia física a la misma, sino que es suficiente con que haya elementos coercitivos en la conducta. 220

Como parte de su análisis la Corte retoma el Preámbulo de la Convención Interamericana para Prevenir, Sancionar y Erradicar la Violencia contra las Mujeres: "... la violencia contra la mujer no sólo constituye una violación de los derechos humanos, sino que es "una ofensa a la dignidad humana y una manifestación de las relaciones de poder históricamente desiguales entre mujeres y hombres", que "trasciende todos los sectores de la sociedad independientemente de su clase, raza o grupo étnico, nivel de ingresos, cultura, nivel educacional, edad o religión y afecta negativamente sus propias bases". ${ }^{221}$

Una vez analizada y acreditada la violación sexual, es que la Corte entra al análisis de los tres requisitos de la tortura: la intencionalidad; los sufrimientos físicos o mentales; y el fin o propósito.

\footnotetext{
${ }^{219}$ ColDH, Caso Inés Fernández Ortega y otros Vs. México, Sentencia de 30 de agosto de 2010, Excepción Preliminar, Fondo, Reparaciones y Costas, párr. 100

${ }^{220}$ Corte Europea de Derechos Humanos, Caso M.C. v. Bulgaria, Sentencia de 04 de diciembre de 2003, párr.166 y Corte Penal Internacional para la Ex Yugoslavia, Caso Dragoljub Kunarac, Radomir Kovac y Zoran Vukovic, op. cit., párr. 452 y 464 , citado por ColDH, Caso Inés Fernández Ortega y otros Vs. México, op. cit., párr. 115

${ }^{221}$ OEA, Convención Interamericana para Prevenir, Sancionar y Erradicar la Violencia contra la Mujer. Preámbulo.
} 


\subsubsection{La intencionalidad}

En cuanto a la intencionalidad la Corte se remite a la pruebas con las cuales da por probado que el maltrato fue deliberadamente infligido en contra de la víctima, donde uno de los atacantes tomó a la señora Fernández Ortega de las manos, la obligó a acostarse en el suelo, y mientras era apuntada al menos con un arma, un militar la penetró sexualmente mientras los otros dos presenciaban la ejecución de la violación sexual.

\subsubsection{Los sufrimientos físicos y mentales}

Por lo que hace a los sufrimientos físicos y mentales, la Corte retoma lo planteado en el caso Villagrán Morales y Otros Vs Guatemala (Caso niños de la calle), haciendo referencia a los elementos a tomar en cuenta para probar la tortura, señalando entre estos: "las características del trato, tales como la duración, el método utilizado o el modo en que fueron infligidos los padecimientos, los efectos físicos y mentales que éstos pueden causar, así como las condiciones de la persona que padece dichos sufrimientos, entre ellos, la edad, el sexo, el estado de salud, entre otras circunstancias personales." ${ }^{222}$

En cuanto a las lesiones físicas, la Corte refiere que si bien existe un certificado médico que indica la inexistencia de lesiones físicas (certificado que fue realizado tres días después de los hechos), si existen testimoniales que indican que Inés al día siguiente de la agresión se encontraba lastimada, con malestares y dolores físicos, e incluso requirió la asistencia de un médico particular. Con ello, la Corte no le da todo el peso de la prueba a las evidencias físicas, como son las lesiones, y en ese sentido retoma lo ya establecido en el caso Cantoral Benavides Vs Perú, con relación a la tortura y sus efectos psicológicos, al establecer que la tortura no sólo se perpetra con actos de violencia física, sino también mediante actos que generan a las víctimas sufrimientos psíquicos y morales agudos. ${ }^{223}$

\footnotetext{
${ }^{222}$ ColDH, Caso de los Niños de la Calle (Villagrán Morales y Otros) Vs. Guatemala, Sentencia de 19 de noviembre de 1999, Fondo, párr. 74, citado por ColDH, Caso Inés Fernández Ortega y otros Vs. México, op. cit., párr. 122

${ }^{223}$ ColDH, Caso Cantoral Benavides Vs Perú, Sentencia de 18 de agosto de 2000, fondo, párr. 100, citado por ColDH, Caso Inés Fernández Ortega y otros Vs. México, op. cit., párr. 124
} 
Así, la Corte establece que "es inherente a la violación sexual el sufrimiento severo de la víctima, aun cuando no exista evidencia de lesiones o enfermedades físicas. En efecto, no en todos los casos las consecuencias de una violación sexual serán enfermedades o lesiones corporales. Las mujeres víctimas de violación sexual también experimentan severos daños y secuelas psicológicas y aun sociales. "224

\subsubsection{La finalidad}

Al analizar la finalidad por la cual se ejerció el acto de tortura contra Inés Fernández, la Corte resuelve que ésta consistió en el castigo por la falta de información requerida al ser interrogada por los agentes militares. ${ }^{225}$

Por lo anterior, y tras haber comprobado el cumplimiento de los requisitos necesarios para la tipificación de la tortura, la Corte concluye que la violación sexual en el presente caso implicó una violación a la integridad personal de la señora Fernández Ortega, constituyendo un acto de tortura en los términos del artículo 5.2 de la Convención Americana y 2 de la Convención Interamericana para Prevenir y Sancionar la Tortura.

Otro aspecto a destacar es el encuadre que hace la Corte de la violación sexual como violatoria a la protección de la honra y la dignidad, establecido en el artículo 11 de la $\mathrm{CADH}$, en el aspecto de que su contenido incluye la protección a la vida privada, y en este sentido consideró que la violación sexual de la señora Fernández Ortega vulneró valores y aspectos esenciales de su vida privada, supuso una intromisión en su vida sexual y anuló su derecho a tomar libremente las decisiones respecto con quien tener relaciones sexuales, perdiendo de forma completa el control sobre sus decisiones más personales e íntimas y sobre las funciones corporales básicas. ${ }^{226}$

De tal forma la Corte concluyó la responsabilidad del Estado por la violación de los derechos a la integridad personal, a la dignidad y a la vida privada, consagrados en los

\footnotetext{
${ }^{224}$ ColDH, Caso Inés Fernández Ortega y otros Vs. México, op. cit., párr. 124

${ }^{225}$ Ibídem., párr. 127

${ }^{226}$ Ibíd., párr. 129
} 
artículos 5.2, 11.1 y 11.2 de la $\mathrm{CADH}$, en relación con los artículos 1.1 del mismo tratado y 1, 2 y 6 de la Convención Interamericana para Prevenir y Sancionar la Tortura, así como por el incumplimiento del deber establecido en el artículo 7a de la Convención Interamericana para Prevenir, Sancionar y Erradicar la Violencia contra la Mujer.

\subsubsection{Análisis de los principales aportes de la Sentencia}

La presente sentencia genera un precedente de suma importancia para la defensa de los derechos humanos de las mujeres en casos de violencia sexual, al determinar que la violación sexual es un delito de comisión oculta, por lo que no puede exigirse la existencia de pruebas gráficas o documentales, constituyendo así la declaración de la víctima una prueba fundamental, es decir la Corte otorga pleno valor probatorio a la declaración de la víctima.

Tal estándar es de gran ayuda para sustentar los casos de violación sexual en el ámbito interno de los países, donde los operadores de justicia con gran prevalencia solicitan pruebas de imposible obtención para las mujeres, como son las declaraciones de testigos, la evidencia de violencia física tanto corporal, como vaginal y la oposición de resistencia, pruebas que obstaculizan el adecuado acceso a la justicia para las mujeres, pues dichas exigencias pasan por alto los distintos medios de coacción, intimidación o amenazas con las que se produce la violencia sexual y que provocan que las mujeres se encuentren en estado de shock y no opongan resistencia, lo que a todas luces no genera ciertas lesiones físicas a las víctimas. Asimismo pasan por alto las consecuencias de género de la violación sexual contra las mujeres, ya que las mujeres en ocasiones no denuncian los hechos o no lo hacen inmediatamente, lo que elimina ciertas pruebas de la violencia sexual ejercida.

Este precedente de la Corte significa un avance en la justicia de género al hacer frente a la interpretación y aplicación de la ley permeada por prejuicios y estereotipos de género en el ámbito interno de los países. Precedente que como ya se observó no fue utilizado en su primer sentencia de violencia sexual, el caso Loayza Tamayo, donde la Corte no otorgó 
pleno valor probatorio a la declaración de la víctima, considerando también la falta de pruebas que acreditaran la violación sexual.

Es de observase también que la Corte refuerza los precedentes respecto a los elementos que configuran la tortura; la intencionalidad, los sufrimientos físicos y mentales y la finalidad, robusteciendo respecto al segundo elemento que no es necesaria la existencia de lesiones físicas, bastando los sufrimientos psíquicos y morales que produce la tortura.

Asimismo, nuevamente la Corte emplea la Convención de Belém do Para para responsabilizar al Estado por el incumplimiento de sus obligaciones.

\subsection{Caso Valentina Rosendo Cantú Vs México}

Sentencia de 31 de agosto de 2010

\section{Excepción preliminar, Fondo, Reparaciones y Costas}

El caso Valentina Rosendo Cantú es el segundo que conoce el Sistema Interamericano por actos de violencia sexual contra mujeres, perpetrados por Militares en México.

Los hechos suceden en febrero de 2002, posteriormente en noviembre de 2003 después de una serie de irregularidades por parte de las autoridades competentes se presenta la petición ante la Comisión Interamericana de Derechos Humanos y ésta en octubre de 2006, declara la admisibilidad No. 93/06.

El 27 de marzo de 2009 la Comisión aprobó el informe de fondo 36/09, realizando una serie de recomendaciones al Estado y concediéndole un plazo de dos meses para que informara las acciones implementadas en el cumplimiento de las recomendaciones, el Estado solicitó una prórroga para la presentación de dicho informe, concediéndosele el término de un mes, sin embargo el Estado no rindió su informe.

Finalmente, el 02 de agosto de 2009 la Comisión presentó el caso a la Corte haciendo referencia a la falta de debida diligencia en la investigación y sanción de los responsables 
de los hechos; la falta de reparación del daño de forma adecuada en favor de la víctima y sus familiares; la utilización del fuero militar para la investigación y juzgamiento de violaciones a los derechos humanos; y las dificultades que enfrentan las personas indígenas, en particular las mujeres, para acceder a la justicia y a los servicios de salud. ${ }^{227}$

El 31 de agosto de 2010 la Corte Interamericana dictó Sentencia determinando la responsabilidad de México por violaciones a la integridad personal, la dignidad, la vida privada, los derechos del niño(a), las garantías de acceso a la justicia y la protección judicial en perjuicio de Valentina Rosendo Cantú.

Un punto importante a destacar sobre el presente caso (y el caso Inés Fernández Ortega Vs. México), es que los hechos perpetrados en contra de Valentina, es decir la violación sexual por parte de militares, se dan en un contexto de militarización de la sierra de Guerrero, no siendo éste un caso aislado, pues existe documentación ${ }^{228}$ de cinco actos similares en contra de otras mujeres por parte de los Militares, es decir, esta situación permite observar como la violencia sexual en contra de las mujeres y en específico indígenas por parte de militares, se convierte en una práctica sistemática de tortura con la finalidad de obtener confesiones, intimidar, castigar y horrorizar a la población.

\subsubsection{Resumen de los hechos}

De acuerdo al informe de admisibilidad de la $\mathrm{CIDH}$, de fecha 21 de octubre de 2006, ${ }^{229}$ el 16 de febrero de 2002 Valentina Rosendo Cantú, de 17 años de edad, indígena del pueblo Tlapaneca, se encontraba lavando ropa en un arroyo ubicado a unos 200 metros de su domicilio, cuando aparecieron dos soldados acompañados de un civil que traían amarrado. Dos de los soldados se acercaron a Valentina, mientras que los otros la rodearon y enojados le preguntaron dónde estaban los encapuchados, ella respondió que no conocía a ninguno, lo que provocó que un militar le apuntara con un arma y

\footnotetext{
${ }^{227} \mathrm{CIDH}$, demanda ante la Corte Interamericana de Derechos Humanos, Caso Valentina Rosendo Cantú y Otra (Caso 12.579) contra los Estados Unidos Mexicanos, 02 de agosto de 2009, párr. 2

${ }^{228}$ A este respecto el Informe Mujeres Indígenas e Injusticia Militar, México, del 23 de noviembre de 2004, elaborado por Amnistía Internacional, documenta los casos de 6 mujeres que han sido violadas por soldados en el Estado de Guerrero. Disponible en http://www.amnesty.org/es/library/asset/AMR41/033/2004/es/c9fa2e2d-d57c-11dd-bb24-1fb85fe8fa05/amr410332004es.pdf

${ }^{229} \mathrm{CIDH}$, Informe de Admisibilidad № 93/06, Petición 972-03, Valentina Rosendo Cantú y otros Vs México, párr. 6-8
} 
amenazándola con dispararle le preguntó si ella era de Barranca Bejuco, Valentina respondió que no, que era de Caxiltepec. Posteriormente uno de los militares le mostró una fotografía y le preguntó si conocía a la persona, a lo que ella contestó que no.

Los militares le continuaron preguntando sobre unos nombres escritos en una lista y si los conocía, a lo que ella respondía negativamente. El militar que le apuntaba con el arma le dio un culatazo en el estómago y por el golpe cayó al piso boca arriba sobre unas piedras desmayándose momentáneamente, al recobrar el conocimiento se sentó y uno de los militares tomándole de los cabellos y de manera violenta le dijo ¿Cómo que no sabes, no eres de Barranca Bejuco?, contestándoles una vez más que no, que era de Caxitepec, que vivía en Barranca Bejuco porque se acababa de casar. Los dos militares procedieron a rasguñarle la cara, le quitaron la falda, el fondo y la pantaleta que llevaba puesta y la acostaron en el piso, uno de ellos la violó por un lapso de 5 a 6 minutos y el otro militar hizo lo mismo, mientras otros seis militares presenciaban los hechos.

\subsubsection{Sentencia de la Corte}

Al igual que en la sentencia del caso Inés Fernández Ortega Vs. México, la Corte comienza por examinar la prueba de la violación sexual a la señora Rosendo Cantú y es ahí donde fija nuevamente el estándar relacionado a la exigencia de pruebas gráficas y documentales, en el siguiente sentido:

“...para la Corte es evidente que la violación sexual es un tipo particular de agresión que, en general, se caracteriza por producirse en ausencia de otras personas más allá de la víctima y el agresor o los agresores. Dada la naturaleza de esta forma de violencia, no se puede esperar la existencia de pruebas gráficas o documentales y, por ello, la declaración de la víctima constituye una prueba fundamental sobre el hecho." 230

\footnotetext{
${ }^{230}$ ColDH, Caso Rosendo Cantú y otra Vs México, Sentencia de 31 de agosto de 2010, Excepción preliminar, Fondo, Reparaciones y Costas, párr. 89
} 
Asimismo, con relación a las contradicciones u omisiones en la declaración de la víctima (ya que en sus dos primeras declaraciones en centros de salud negó haber sido agredida sexualmente), la Corte refiere que tal situación debe ser contextualizada en las circunstancias propias del caso y de la víctima, pues las agresiones sexuales suelen ser un tipo de delito que las víctimas no denuncian, lo que sucede en comunidades indígenas por las particularidades socioculturales a las que se tienen que enfrentar, aunado al miedo. ${ }^{231}$

Una vez acreditado que Valentina fue víctima de agresión sexual por parte de agentes estatales, la Corte tipifica la violencia sexual como constitutiva de actos de tortura a partir de sus estándares jurisprudenciales emitidos en los casos Bueno Alves Vs. Argentina, referentes a la existencia de los tres requisitos exigidos por la definición de la Convención Interamericana para Prevenir y Sancionar la Tortura, es decir, que el acto sea intencional, que cause severos sufrimientos físicos o mentales y que sea cometido con determinado fin o propósito. ${ }^{232}$ Posteriormente los analiza en el siguiente sentido:

\subsubsection{La intencionalidad}

En cuanto al requisito de que exista intencionalidad al perpetrar el acto de tortura, la Corte, considera que:

"de las pruebas que constan en el expediente queda acreditado que el maltrato fue deliberadamente infligido en contra de la víctima. En efecto, la Corte considera probado que uno de los atacantes golpeó en el abdomen a la señora Rosendo Cantú con su arma, cayendo la víctima al suelo, posteriormente la tomaron del cabello y le rasguñaron la cara y, por la fuerza, mientras era apuntada con un arma, fue penetrada sexualmente por dos militares, mientras otros seis presenciaban la ejecución de la violación sexual."233

\footnotetext{
${ }^{231}$ Ibídem., párr. 95

${ }^{232}$ Ibíd., párr. 110

${ }^{233}$ Ibíd., párr. 111
} 


\subsubsection{El sufrimiento físico y mental severo}

Por lo que hace al sufrimiento físico o mental severo, la Corte comienza por mencionar la existencia de dos certificados médicos que indican la evidencia de lesiones físicas, así como el testimonio de la agraviada que indica que con posterioridad a los hechos se encontraba lastimada y con dolores físicos, requiriendo de la asistencia de dos médicos.

Sin embargo, la Corte va más allá, al analizar lo ya establecido en sus interpretaciones anteriores, en el sentido que "un acto de tortura puede ser perpetrado tanto mediante actos de violencia física como a través de actos que produzcan en la víctima un sufrimiento psíquico o moral agudo", ${ }^{234}$ dejando de lado el requisito único de la evidencia física, que por lo menos en lo que hace a la aplicación e interpretación de la ley, es de gran peso y para muchos fiscales del ministerio público es imprescindible la evidencia de lesiones físicas a través de certificados médicos que den fe de la integridad física corporal, o de los certificados ginecológicos que determinen la existencia de lesiones internas vaginales, siendo esto una constante que obstaculiza el acceso a la justicia para las mujeres víctimas de violencia.

Así la Corte refuerza lo anterior y avanza en sus criterios determinando que:

"...es inherente a la violación sexual el sufrimiento severo de la víctima, aun cuando no exista evidencia de lesiones o enfermedades físicas. En efecto, no en todos los casos las consecuencias de una violación sexual serán enfermedades o lesiones corporales. Las mujeres víctimas de violación sexual también experimentan severos daños y secuelas psicológicas y aun sociales. "235

Este tipo de criterios y análisis permiten observar el contenido de género en las resoluciones de la Corte, pues al hacer mención de las secuelas psicológicas y sociales, pueden encuadrarse aquellas que derivan de un contexto sociocultural al cual se encuentran inmersas las mujeres por su condición de género y por los roles

\footnotetext{
${ }^{234}$ ColDH, Caso Cantoral Benavides Vs. Perú, Sentencia de 18 de agosto de 2000, Fondo, párr. 100 y Caso Maritza Urrutia Vs. Guatemala, Sentencia de 27 de noviembre de 2003, Fondo, Reparaciones y Costas, párr. 91, citado por ColDH, Caso Rosendo Cantú y otra Vs México, op. cit., párr. 114

${ }^{235} \mathrm{CoIDH}$, Caso Rosendo Cantú y otra Vs México, op. cit., párr. 112
} 
estereotipados asignados, donde para una mujer una violación sexual tiene diversas implicaciones, como lo es el ostracismo público, terminó que empleo la Comisión en el Caso Ana, Beatriz y Celia González para referirse a la exclusión a la que pueden ser sujetas las mujeres dentro de su comunidad por el hecho de haber sido víctimas de violencia sexual.

Como el ostracismo social, hay otras consecuencias a las que se enfrentan las mujeres que son sometidas a este tipo de vejámenes, a este respecto Amnistía Internacional al documentar los seis casos de violencia sexual ejercidos por militares contra mujeres en Guerrero establece:

"Algunas han dejado su comunidad. Una de las mujeres tuvo que someterse a tratamiento médico por una infección de transmisión sexual que adquirió durante la violación. En algunos casos, el compañero ha sido incapaz de aceptar lo sucedido, y el estigma asociado a la violación ha intensificado fricciones en la familia. La presencia del ejército en la región es un constante recordatorio del trauma sufrido por las mujeres."236

Los elementos empleados por la Corte para ubicar los daños físicos y mentales son reforzados con lo concluido por el peritaje psicológico realizado a la víctima que acredita la humillación, incapacidad, desesperación, angustia, vergüenza y traumas experimentados.

\subsubsection{La finalidad}

A este respecto la Corte concluye que la finalidad se produjo en el momento en que los militares interrogaron a Valentina y no obtuvieron respuesta sobre la información solicitada. Sin descartar la eventual concurrencia de otras finalidades, considerando probada la finalidad específica de castigo ante la falta de información solicitada. ${ }^{237}$

\footnotetext{
${ }^{236}$ Amnistía Internacional, op. cit., p. 7

${ }^{237}$ ColDH, Caso Rosendo Cantú y otra Vs México, op. cit., párr. 117
} 
De esta forma, la Corte concluye que la violación sexual implicó una violación a la integridad personal de la señora Rosendo Cantú, constituyendo un acto de tortura en los términos de los artículos 5.2 de la CADH y 2 de la Convención Interamericana para Prevenir y Sancionar la Tortura.

Al igual que en el caso Inés Fernández Ortega, la Corte enmarco el acto de violencia sexual como violatoria al derecho a la protección de la honra y la dignidad que incluye la protección a la vida privada, ya que la violación sexual supuso una intromisión en su vida sexual y anuló su derecho a tomar libremente las decisiones respecto con quien tener relaciones sexuales, perdiendo de forma completa el control sobre sus decisiones más personales e íntimas. ${ }^{238}$

Finalmente la Corte determino la responsabilidad del Estado por la violación de los derechos a la integridad personal, a la dignidad y a la vida privada, consagrados, respectivamente, en los artículos 5.2, 11.1 y 11.2 de la Convención, en relación con los artículos 1.1 del mismo tratado y 1, 2 y 6 de la Convención Interamericana para Prevenir y Sancionar la Tortura, así como por el incumplimiento del deber establecido en el artículo 7.a de la Convención Interamericana para Prevenir, Sancionar y Erradicar la Violencia contra la Mujer.

Otro aspecto importante a destacar en el presente caso, es que aún a pesar de existir en el Sistema Interamericano precedentes en cuanto al deber del Estado Mexicano de declarar la incompetencia del fuero Militar para conocer delitos y violaciones a los derechos humanos cometidos por sus propios agentes, debiéndose conocer e investigar en el fuero común, la investigación penal del caso se remite por parte de la Procuraduría General de Justicia del Estado al Fuero Militar.

En el mismo sentido encontramos la resolución de la Comisión Interamericana en el caso Ana, Beatriz y Celia González Pérez Vs. México, donde se recomienda al Estado Mexicano

\footnotetext{
${ }^{238}$ Ibídem., párr. 119
} 
la incompetencia del fuero Militar para conocer delitos cometidos contra la población por la falta de imparcialidad. ${ }^{239}$

De igual forma, encontramos la Sentencia de la Corte Interamericana en el caso Radilla Pacheco Vs México, misma que es reiterada por el Tribunal en el presente caso, donde establece con base a lo ya interpretado en diversas sentencias contra Perú, Colombia, Chile y Guatemala que:

“... en un Estado democrático de derecho, la jurisdicción penal militar ha de tener un alcance restrictivo y excepcional y estar encaminada a la protección de intereses jurídicos especiales, vinculados a las funciones propias de las fuerzas militares. Por ello, el Tribunal ha señalado anteriormente que en el fuero militar sólo se debe juzgar a militares activos por la comisión de delitos o faltas que por su propia naturaleza atenten contra bienes jurídicos propios del orden militar.

... la Corte en múltiples ocasiones ha indicado que: "cuando la justicia militar asume competencia sobre un asunto que debe conocer la justicia ordinaria, se ve afectado el derecho al juez natural y, a fortiori, el debido proceso", el cual, a su vez, se encuentra íntimamente ligado al propio derecho de acceso a la justicia. El juez encargado del conocimiento de una causa debe ser competente, además de independiente e imparcial." 240

Sin embargo aun existiendo estos precedentes en México, nuevamente el Estado a través de sus agentes y haciendo caso omiso a las sentencias de la Corte y las resoluciones de la Comisión, conoce el caso a través de la Justicia Militar de Guerrero, lo cual implica un obstáculo para que Valentina accediera a la justicia en condiciones de igualdad, ante la falta de imparcialidad de quienes investigaron lo agravios cometidos en su contra.

A pesar de que la agraviada interpuso el recurso de amparo solicitando se declinara la competencia a la Procuraduría Estatal, ya que son las autoridades civiles las que deben

\footnotetext{
${ }^{239}$ Véase Comisión Interamericana de Derechos Humanos, informe de fondo № 53/01, del caso 11.565, Ana, Beatriz y Celia González Pérez Vs. México, 04 de abril de 2001, primera recomendación.

${ }^{240} \mathrm{ColDH}$, Caso Radilla Pacheco Vs México, Excepciones Preliminares, Fondo, Reparaciones y Costas, Sentencia de 23 de Noviembre de 2009, párr. 272-275
} 
investigar dicho delito y no la Justicia Militar por carecer de imparcialidad e independencia, el amparo fue declarado improcedente, agotándose ante tal decisión el recurso de revisión de amparo, cuya sentencia confirmó la improcedencia resuelta mediante amparo.

Es decir, no bastó con el incumplimiento de obligaciones por parte de la Procuraduría al resolver se turnara el asunto a la Justicia Militar, sino que también las autoridades de segunda instancia obligadas a resolver el amparo, hacen caso omiso a las recomendaciones de la CoIDH.

Es así, como la Corte concluye que el Estado violó el derecho a las Garantías Judiciales y a la Protección Judicial, estableciendo también que:

"La violación sexual de una persona por parte de personal militar no guarda, en ningún caso, relación con la disciplina o la misión castrense. Por el contrario, el acto cometido por personal militar contra la señora Rosendo Cantú afectó bienes jurídicos tutelados por el derecho penal interno y la Convención Americana como la integridad y la dignidad personal de la víctima. Es claro que tal conducta es abiertamente contraria a los deberes de respeto y protección de los derechos humanos y, por lo tanto, está excluida de la competencia de la jurisdicción militar..."241

\subsubsection{Análisis de los principales aportes de la sentencia}

En el presente caso la Corte reitera el estándar usado en la sentencia del caso Inés Fernández Ortega, con relación a la prohibición de exigencia de pruebas gráficas y documentales para acreditar la violación sexual, donde la declaración de la víctima constituye una prueba fundamental, consolidándose así la permanencia de tal estándar jurisprudencial.

\footnotetext{
${ }^{241}$ CoIDH, Caso Rosendo Cantú y otra Vs México, op. cit., párr. 161
} 
Un aporte fundamental es que la Corte refuerza los estándares fijados por la Comisión Interamericana en el caso Raquel Martín de Mejía y en el caso de las hermanas González, al tomar en cuenta que las agresiones sexuales suelen ser un delito que las víctimas no denuncian y que en tales situaciones deben tomarse en cuenta las circunstancias propias del caso y de la víctima, analizando así la especificidad del contexto de Valentina, en el sentido de que en las comunidades indígenas es común que las mujeres no denuncien por las particularidades socioculturales a las que se enfrentan, aunado al miedo. Estándar que permite observar como la justicia de género en el Sistema toma en cuenta las características específicas de las víctimas y su nexo con el contexto, alejándose de una impartición de justicia totalitarista.

Haber generado este precedente jurisprudencial es fundamental en la defensa de los derechos humanos de las mujeres, pues permite tomar en cuenta no sólo factores de género, sino también étnicos (que en la mayoría de los casos están vinculados a usos y costumbres que afectan principalmente a las mujeres), que están ligados a las consecuencias y particularidades de la violencia sexual contra las mujeres y que deben ser tomados en cuenta en la administración e impartición de justicia en el ámbito interno de los países, ya que en la mayoría de los casos la actuación de los operadores de justicia es muy rígida, estructural y de nula sensibilidad para tratar desde un enfoque étnico y de género los casos de violencia contra las mujeres.

Al igual que en caso de Inés Fernández Ortega, en éste la Corte analiza la violencia sexual a partir de los tres elementos para configurar la tortura; la intencionalidad, el sufrimiento físico y mental; y la finalidad, destacando que en el segundo elemento ya no hace sólo referencia al sufrimiento físico y moral, sino que ahora menciona también la secuelas sociales, lo que permite observar las consecuencias de la violencia sexual ligadas a la humillación, al ostracismo público y a la vergüenza, donde las mujeres son estigmatizadas y desvalorizadas socialmente. Esto permite observar la particularidad de los efectos de la violencia sexual en el caso de las mujeres por razones étnicas y de género. 
Otro precedente de suma importancia, que como ya se mencionó en apartados anteriores es la reiteración por parte del Sistema Interamericano de la declaración de la incompetencia del fuero militar para conocer de violaciones a derechos humanos en México, por carecer de imparcialidad e independencia, sin embargo, tal estándar no tuvo consecuencias a nivel interno, sino hasta el 2011, mediante la resolución de supervisión del cumplimiento de la sentencia del caso Radilla Pacheco por parte de la Corte, donde por primera vez en México se reforma el Código de Justicia Militar para dar cumplimiento a lo exigido por la Corte.

Finalmente la Corte emplea la Convención de Belém do Pará para determinar la responsabilidad estatal por el incumplimiento de las obligaciones del artículo 7, lo que permite observar, en armonía con los casos anteriores, el reconocimiento y consolidación de dicho instrumento en el Sistema Interamericano.

\subsection{Caso J. V.s. Perú}

Sentencia de 27 de noviembre de 2013

\section{Excepción Preliminar, Fondo, Reparaciones y Costas}

Los hechos del caso sucedieron el 13 de abril de 1992. La petición se presentó a la Comisión el 17 de junio de 1997, finalmente el 14 de marzo de 2008 la Comisión aprobó el Informe de Admisibilidad No. 27/08.

El 20 de julio de 2011 la Comisión aprobó el Informe de Fondo No. 76/11 conforme al artículo 50 de la Convención, a través del cual realizó una serie de recomendaciones al Estado, concluyendo la responsabilidad estatal por la violación de los artículos 5, 7, 8, 9, 11 y 25 de la Convención, en relación con los artículos 1.1 y 2 del mismo instrumento, así como la violación de las obligaciones establecidas en los artículos 1, 6 y 8 de la Convención Interamericana para Prevenir y Sancionar la Tortura y 7 de la Convención Interamericana para Prevenir, Sancionar y Erradicar la Violencia contra la Mujer, en perjuicio de la señora J. 
El informe le fue notificado al Estado el 4 de agosto de 2011, otorgándosele un plazo de dos meses para informar sobre el cumplimiento de las recomendaciones, no obstante ante la solicitud de Perú la Comisión otorgó una prórroga. El 20 y 28 de diciembre de 2011, el Estado presentó un informe sobre las medidas adoptadas para dar cumplimiento a las recomendaciones emitidas, sin embargo, ante el incumplimiento de las recomendaciones por parte del Estado, la Comisión sometió el caso a la Corte el 04 de enero de 2012 y la Corte resolvió el fondo mediante la sentencia del 27 de noviembre de 2013.

\subsubsection{Resumen de los hechos}

De acuerdo a la petición presentada ante la CoIDH, el 13 de abril de 1992 la Señora J. fue detenida ilegal y arbitrariamente por parte de agentes estatales, quienes incurrieron en actos de tortura y tratos crueles, inhumanos y degradantes, incluida la violación sexual. Posteriormente fue trasladada a la Dirección Nacional contra el Terrorismo (DINCOTE) y privada de la libertad sin control judicial y en condiciones inhumanas, durante 17 días. Durante su proceso penal por supuestos delitos de terrorismo se cometieron una serie de violaciones al debido proceso y al principio de legalidad e irretroactividad. La señora J. fue absuelta en junio de 1993, empero, el 27 de diciembre de 1993 la Corte Suprema de Justicia sin rostro declaró nula la absolución disponiendo un nuevo juicio. Actualmente existe un proceso abierto contra la señora J. con una orden de captura internacional, ya que ella salió del país.

La Corte para entrar al estudio de los hechos del caso comenzó por analizarlo desde cuatro aspectos:

\subsubsection{El contexto en que se enmarcaron los hechos del presente caso ${ }^{242}$}

Para analizar el contexto político e histórico la Corte se basó principalmente en el Informe de la Comisión de la Verdad y Reconciliación (CVR) del 28 de agosto de 2003 y en la evidencia recolectada en otras sentencias de la Corte en casos contra Perú. De acuerdo a tal

\footnotetext{
${ }^{242}$ ColDH, Caso J Vs. Perú, Sentencia de 27 de noviembre de 2013, Excepción Preliminar, Fondo, Reparaciones y Costas, párr. 53-64
} 
información, durante el periodo de 1980 al 2000 se vivió en Perú un conflicto entre grupos armados y agentes de las fuerzas policiales y militares. En 1991 el Estado creó la Dirección Nacional Contra el Terrorismo (DINCOTE) como un organismo especializado de la Policía Nacional encargado de prevenir, denunciar y combatir las actividades de terrorismo, así como las de traición a la patria. Dentro de la estructura de la DINCOTE se creó el Grupo Especial de Inteligencia.

Por un lado, el Partido Comunista Sendero Luminoso inició una guerra popular en contra del Estado, desencadenándose así el conflicto armado interno, las acciones de Sendero Luminoso incluían asesinatos con sevicia y coches-bombas en las ciudades, cometiendo graves crímenes que constituyen delitos de lesa humanidad e infracciones al Derecho Internacional Humanitario.

Por otro lado, los agentes estatales siguiendo órdenes militares y policiales desencadenaron una práctica sistemática de violaciones a los derechos humanos, entre ellas ejecuciones extrajudiciales y desapariciones forzadas de personas sospechosas de pertenecer al Partido Comunista del Perú; Sendero Luminoso y al Movimiento Revolucionario Túpac Amaru (MRTA).

Ante tal situación y desde 1981 el estado de emergencia se generalizó, suspendiéndose por períodos renovables de tiempo diversas garantías constitucionales relativas a la inviolabilidad de domicilio, al derecho a la circulación, al derecho de reunión y a la libertad y seguridad personal. En este contexto las tropas del Ejército, la Marina de Guerra, la Fuerza Aérea y la Policía Nacional, tomaron el control de orden interno de la capital y de las principales ciudades del interior.

2.6.1.2 La práctica de detenciones, tortura y tratos crueles, inhumanos y degradantes en la época de los hechos ${ }^{243}$

En este apartado se constató que dentro de las acciones estatales existía un patrón de detenciones violentas, acompañadas de registros domiciliaros. Durante la detención la

\footnotetext{
${ }^{243}$ Ibídem, párr. 65-69
} 
persona era cubierta del rostro, conminada a firmar las actas en los registros, trasladada a alguna dependencia militar o policial donde se decidía si era puesta en libertad o ejecutada arbitrariamente.

De acuerdo a la información recolectada por la CVR durante el periodo de 1980 y 2000, la tortura y otros tratos o penas crueles, inhumanos o degradantes, constituyeron una práctica sistemática y generalizada en el contexto de la lucha contrasubversiva, registrándose 6,443 actos de tortura y tratos o penas crueles, inhumanos o degradantes; el 75\% atribuibles a funcionarios del Estado o personas que actuaron bajo su autorización y/o aquiescencia, y el $23 \%$ imputables al grupo subversivo Sendero Luminoso. Asimismo se produjeron numerosos actos de violencia sexual contra las mujeres peruanas por agresores provenientes tanto del Estado como de los grupos subversivos, constituyendo una práctica generalizada y tolerada.

\subsubsection{La legislación antiterrorista vigente en la época de los hechos ${ }^{244}$}

Tras la instauración del Gobierno de Emergencia y Reconstrucción Nacional, el 5 de mayo de 1992 se emitió el Decreto Ley No. 25.475 que modificó las disposiciones del Código Penal de 1991, en cuanto a los delitos de apología, terrorismo, terrorismo agravado y afiliación a organizaciones terroristas; los delitos de terrorismo se caracterizaron por la incomunicación absoluta de los detenidos, la limitación de la participación del abogado defensor, la improcedencia de la libertad provisional del imputado durante la instrucción, la prohibición de ofrecer como testigos a quienes intervinieron en razón de sus funciones en la elaboración del atestado policial, la sustanciación del juicio en audiencias privadas, la improcedencia de recusación contra los magistrados y auxiliares judiciales, la participación de jueces y fiscales con identidad secreta, y el aislamiento celular continuo durante el primer año de las penas privativas de libertad.

El 12 de agosto de 1992 se promulgó el Decreto Ley No. 25.659 que dispuso la improcedencia de las acciones de garantía de los detenidos, implicados o procesados por delitos de terrorismo. De acuerdo a lo señalado por la CVR la aplicación de la legislación

\footnotetext{
${ }^{244}$ Ibíd., párr. 70-73
} 
antiterrorista implicó detenciones indiscriminadas, procesamientos por delitos no cometidos, fabricación de pruebas, morosidad en los procesos, indefensión de los detenidos y emisión de sentencias sin sustento.

\subsubsection{Las modificaciones a la legislación antiterrorista ${ }^{245}$}

En este apartado se hace referencia a la Ley No. 26.671 del 11 de octubre de 1997, donde se ordenó que el juzgamiento de los delitos de terrorismo previsto en el Decreto Ley 25.475 fuera realizado por magistrados designados e identificados. Asimismo la Sentencia del Tribunal Constitucional de Perú del 3 de enero de 2003, dio origen entre otros, al decreto legislativo No. 926 que dispuso que la Sala Nacional de Terrorismo anulara de oficio, salvo renuncia expresa del reo, la sentencia y el juicio oral, declarando la insubsistencia de la acusación fiscal en los procesos penales por delitos de terrorismo seguidos ante jueces o fiscales de identidad secreta.

\subsubsection{Los hechos probados sobre la señora J. ${ }^{246}$}

La señora J. era bachiller en Derecho de la Pontificia Universidad Católica del Perú y tenía al momento de los hechos 25 años de edad. En marzo de 1992 fue contratada como asistente de producción por el periodista colombiano Marc de Beaufort, quien se encontraba filmando un programa de televisión para WGBH, un canal de televisión pública de Boston, sobre la situación política en Perú, haciendo énfasis en el movimiento guerrillero de "Sendero Luminoso".

En 1992 la DICONTE dispuso un seguimiento a la publicación "El Diario", al determinarse que formaba parte de la agrupación Partido Comunista del Perú "Sendero Luminoso" y realizó algunas intervenciones y detenciones. En lo relativo a la detención de la señora J., se menciona que por la noche del 13 de abril de 1992 funcionarios policiales intervinieron el inmueble ubicado en la calle Las Esmeraldas propiedad de los padres de la señora J.

\footnotetext{
${ }^{245}$ Ibíd., párr. 74-75

${ }^{246}$ Ibíd., párr. 76-121
} 
Según la información del Estado, al llegar al inmueble los ocupantes pretendieron darse a la fuga por una puerta posterior por lo que fueron reducidos y que durante la operación estuvo presente la representante del Ministerio Público tal como se señala en el acta de registro domiciliario. De igual forma señala que durante la intervención fueron detenidos la señora J., otra mujer y un hombre, incautándose propaganda terrorista, manuscritos y documentos mecanografiados del Partido Comunista "Sendero Luminoso".

Según la víctima en el inmueble de la calle Las Esmeraldas nunca funcionó ninguna imprenta, sino que el mismo era utilizado como un local comercial que había sido remodelado para ofrecerlo en alquiler, por lo que al momento de los hechos se encontraba vacío. Asimismo afirmó que la noche del 13 de abril se encontraba en el inmueble solamente con una mujer, quien era una posible inquilina y a quien J. no conocía de antes, que esa noche entraron como quince personas vestidos de civil, armados y la tiraron al piso, amarrándole las manos a la espalda, le vendaron los ojos, la golpearon y la llevaron al fondo del local. Cuando la vendaron uno de los hombres la golpeó en las piernas y la manoseó por completo, según él revisándola. Igualmente mencionó que la representante del Ministerio Público no estuvo en el momento de la intervención policial, sino que llegó después, por lo que no había fiscal que pudiera dar fe de las cosas que supuestamente se encontró en las oficinas. Que al finalizar la intervención, la sacaron a ella y la otra mujer, las llevaron en un carro, dando vueltas toda la noche hasta las seis de la mañana y que durante ese tiempo estuvo vendada y amarrada.

El 14 de abril de 1992 la señora J. fue notificada que se encontraba detenida en la unidad policial de la DINCOTE, para esclarecimiento del delito de Terrorismo. Según la señora J., ella fue llevada a una prefectura a las seis de la mañana del 14 de abril, no obstante, de acuerdo al Registro de Detenidos de la DINCOTE, la señora J. ingresó a dicho centro el 15 de abril de 1992 a las 11:55 horas. El 14 de abril de 1992 la DINCOTE comunicó a una Fiscalía Provincial en lo Penal de Lima y a un Juzgado de Instrucción sobre la detención de la señora J. De acuerdo a lo anterior, la Corte refiere que no consta en el expediente información oficial sobre dónde se encontraba la señora J. entre el 13 y el 14 de abril. 
El 18 de abril de 1992 se realizó un Certificado de Registro Médico Legal a la señora J., donde se establece que se observan excoriaciones pequeñas y equimosis, en proceso de sanación y sin requerir incapacidad.

El Registro de Detenidos de la DINCOTE señala que la señora J. salió del centro de la DINCOTE el 28 de abril de 1992 a las 15:00 horas y que el 30 de abril de 1992 la señora J. ingresó al Instituto Nacional Penitenciario Miguel Castro Castro. En este mismo apartado la Corte analiza el proceso penal contra la señora J., el proceso penal tras las reformas de la ley antiterrorista de 2003 y la salida y extradición de la señora J., los cuales no serán retomados en la presente investigación por no versar sobre el objeto de estudio de la misma; la violación sexual como tortura.

\subsubsection{Sentencia de la Corte}

Respecto al fondo de la sentencia, en primer momento la Corte estudia el derecho a la libertad personal, a la protección del domicilio, a las garantías judiciales y el principio de legalidad, en relación con las obligaciones de respeto y garantía de los derechos y el deber de adoptar disposiciones de derecho interno. Posteriormente la Corte entra al estudio del derecho a la integridad personal y la vida privada en relación con las obligaciones de respeto y garantía de los derechos, donde se examinan los presuntos malos tratos sufridos por la víctima, incluyendo violencia sexual, a partir de tres etapas; los maltratos durante la detención inicial, los maltratos durante la detención en la DINCOTE y otras violaciones a la integridad personal relacionadas a la separación de personas procesadas de las condenadas, sin embargo solo se hará referencia a la primera etapa por ser en esta donde sucedieron los hechos de violencia sexual, objeto de estudio de la presente investigación.

\subsubsection{Los maltratos durante la detención inicial}

En esta etapa la Corte analiza el contexto en la época de los hechos ${ }^{247}$ tomando de referencia el informe de la Comisión de la Verdad y Reconciliación (CVR), con el que se da

\footnotetext{
${ }^{247}$ Ibíd., párr. 315-321
} 
por probado la existencia de un patrón de detenciones violentas, acompañadas de registros domiciliarios (en los cuales la víctima era privada de la visión o cubierta del rostro) y numerosos actos de violencia sexual contra mujeres peruanas por agresores provenientes del Estado; tipo de agresión que era una práctica generalizada y subrepticiamente tolerada. Finalmente la Corte advierte las similitudes entre lo declarado por la presunta víctima y los hallazgos de la CVR, considerando que tales similitudes son un indicio importante sobre lo sucedido en el presente caso.

Posteriormente analiza las declaraciones de la señora J., ${ }^{248}$ determinando que de las mismas consta que fue golpeada y tomada de los cabellos, que un hombre la golpeó entre sus piernas y la manoseó sexualmente y le vendaron los ojos. Respecto al manoseo sexual, la Corte emplea estándares emitidos anteriormente en las sentencias de los casos Inés Fernández Ortega y Valentina Rosendo Cantú, ambos contra México respecto a la no exigencia de pruebas gráficas o documentales en casos de comisión oculta, por lo que la declaración de la víctima constituye un prueba fundamental sobre el hecho, extendiendo la aplicación de dicho estándar a las agresiones sexuales en general (y no únicamente a la violación sexual). ${ }^{249}$

Al analizar lo referente al examen médico legal, ${ }^{250}$ la Corte con base al Protocolo de Estambul refirió que la ausencia de señales físicas no implica que no se hayan producido maltratos, ya que es frecuente que estos actos de violencia no dejen marcas ni cicatrices permanentes. Estándar que refuerza con lo pronunciado en el caso Inés Fernández Ortega Vs. México para referir que lo mismo es cierto para los casos de violencia y violación sexual, ya que no todos los casos ocasionan lesiones físicas o enfermedades verificables a través de un examen médico. ${ }^{251}$ Finalmente la Corte considera que la información que se desprende de dicho examen médico no contradice lo relatado por la señora J., y que el hecho de que

\footnotetext{
${ }^{248}$ Ibíd., párr. 322-326

${ }^{249}$ ColDH, Caso Inés Fernández Ortega y otros Vs. México, op. cit., párr. 100 y Caso Valentina Rosendo Cantú y otra Vs. México, op. cit., párr. 89, citados por ColDH, Caso J Vs. Perú, op. cit, párr. 323.

${ }^{250} \mathrm{ColDH}$, Caso J Vs. Perú, op. cit., párr. 327-334

${ }^{251}$ ColDH, Caso Inés Fernández Ortega y otros Vs. México, op. cit., párr. 124, citado por ColDH, Caso J Vs. Perú, op. cit., párr. 329
} 
no se hubieran practicado otros exámenes para verificar los malos tratos es imputable al Estado y no se puede usar para desvirtuar lo declarado por la víctima.

Consecutivamente la Corte analiza la declaración de la fiscal del Ministerio Público, ${ }^{252}$ ya que el Estado argumentó que durante la detención de la Señora J., estuvo presente la fiscal, quien señaló que la presunta víctima no tuvo ninguna agresión ni en el operativo, ni durante su traslado a la DINCOTE. En esta etapa la Corte observa ciertas contradicciones en lo declarado por la fiscal; al no ser clara sobre si se utilizó o no algún tipo de violencia y al basar su negativa de la existencia de una agresión sexual con el hecho de que la presunta víctima no se lo comunicó para que constara en el acta, aunado a que dicha acta no estaba firmada por la Señora J.

De igual forma, la Corte logra constatar que según el acta de registro del inmueble de la calle Las Esmeraldas, el allanamiento comenzó a las 20:55 horas del 13 de abril de 1992 y finalizó a las 21:15 horas del 14 de abril del mismo año, según la víctima desde las once o doce de la noche del 13 de abril la sacaron del local hasta un carro, y según la fiscal el operativo no duró un día y podría tratarse de un error de confección de acta. Sin embargo, la Corte nota que de acuerdo a diversas actas de registro domiciliario, el 13 de abril la fiscal estuvo en otros cinco operativos distintos desde las 21:20 hasta las 22:50 horas, por lo que para la Corte existen indicios de que la fiscal no estuvo durante toda la operación y que su presencia en diligencias inmediatamente posteriores a la detención de la señora J., evidencia una contradicción con lo afirmado por la fiscal en el sentido de que tras el allanamiento del domicilio condujo a la víctima directamente a la DINCOTE.

Relativo a lo alegado por la fiscal respecto a que la víctima no le comunicó ninguna agresión para que constara en el acta, es importante destacar que la Corte reitera un estándar trascendente, en el sentido de que ello no implica que los malos tratos no hayan ocurrido, ya que las víctimas suelen abstenerse por temor de denunciar la tortura o malos tratos,

\footnotetext{
${ }^{252}$ ColDH, Caso J Vs. Perú, op. cit., párr. 335-340
} 
sobre todo si se encuentran detenidas en el mismo recinto donde estos ocurrieron ${ }^{253} \mathrm{y}$ agrega:

"...es importante resaltar que al momento en el cual presuntamente se realizó el acta de registro posiblemente se encontraban presentes los alegados perpetradores de los maltratos, por lo que no era un ambiente cómodo y seguro, que brindara privacidad y confianza para relatar los alegados maltratos. ${ }^{254}$

Más adelante la Corte analiza la falta de investigación de los hechos, ${ }^{255}$ estableciendo que de acuerdo al artículo 1.1 de la $\mathrm{CADH}$, la obligación de garantizar los derechos reconocidos en los artículos 5.1 y 5.2 de dicha convención implica el deber de investigar posibles actos de tortura u otros tratos crueles, inhumanos o degradantes. Obligación que se refuerza por lo dispuesto en los artículos 1, 6 y 8 de la Convención Interamericana contra la Tortura y 7b de la convención de Belém do Pará respecto a actuar con la debida diligencia para prevenir, investigar y sancionar la violencia contra la mujer.

La Corte precisa que respecto a esta obligación reforzada de investigar hechos de violencia sexual con la debida diligencia es necesario que:

“i) la declaración de la víctima se realice en un ambiente cómodo y seguro, que le brinde privacidad y confianza; ii) la declaración de la víctima se registre de forma tal que se evite o limite la necesidad de su repetición; iii) se brinde atención médica, sanitaria y psicológica a la víctima, tanto de emergencia como de forma continuada si así se requiere, mediante un protocolo de atención cuyo objetivo sea reducir las consecuencias de la violación; iv) se realice inmediatamente un examen médico y psicológico completo y detallado por personal idóneo y capacitado, en lo posible del sexo que la víctima indique, ofreciéndole que sea acompañada por alguien de su confianza si así lo desea; v) se documenten y coordinen los actos investigativos y se maneje diligentemente la prueba, tomando muestras suficientes, realizando estudios

\footnotetext{
${ }^{253}$ ColDH, Caso Bayarri Vs. Argentina, Sentencia de 30 de octubre de 2008, Excepción Preliminar, Fondo, Reparaciones y Costas, párr. 92 y Caso Vélez Loor Vs. Panamá, Sentencia de 23 de noviembre de 2010, Excepciones Preliminares, Fondo, Reparaciones y Costas, párr. 236, citado por ColDH, Caso J. Vs. Perú, op. cit., párr. 337

${ }^{254}$ ColDH, Caso J. Vs. Perú, op. cit., párr. 337

${ }^{255}$ Ibídem., párr. 341-353
} 
para determinar la posible autoría del hecho, asegurando otras pruebas como la ropa de la víctima, investigando de forma inmediata el lugar de los hechos y garantizando la correcta cadena de custodia, y vi) se brinde acceso a asistencia jurídica gratuita a la víctima durante todas las etapas del proceso."256

En este apartado se analizan una serie de justificantes que el Estado opuso respecto a la no investigación de los hechos, tales como que las declaraciones de la víctima eran muy generales, por lo que las autoridades no identificaron una situación que pudiera constituir tortura; que al momento de los hechos no existía una obligación de investigar manoseos sexuales; que éstos no constituían un indicio para presumir una violación sexual, la cual además era un delito de acción privada en ese momento y que ha sido usual que las procesadas por terrorismo aleguen indebidamente haber sido víctimas de violación sexual. Con respecto a tales justificaciones, la Corte concluye que:

"...dicho alegato evidencia una concepción que (i) asume automáticamente que las denuncias de violencia sexual son falsas, contrario al deber de iniciar una investigación de oficio cada vez que se presente una denuncia o existan indicios de su ocurrencia; (ii) es contraria al contexto de violencia sexual existente en la época de los hechos; (iii) desconoce que no todos los casos de violación y/o violación sexual ocasionan lesiones físicas verificables a través de un examen médico, y (iv) muestra un criterio discrecional y discriminatorio con base en la situación procesal de las mujeres para no iniciar una investigación por una alegada violación o violencia sexual."257

Así la Corte concluye que la investigación que debe iniciar el Estado a partir del conocimiento del hecho, debe ser seria, imparcial y efectiva, y no puede estar condicionada por quien realiza la denuncia, ni por la creencia de las autoridades de que las alegaciones son falsas. ${ }^{258}$

\footnotetext{
${ }^{256}$ Ibíd., párr. 344

${ }^{257}$ Ibíd., párr.352

258 Ibíd.
} 
En la determinación sobre los maltratos ocurridos, ${ }^{259}$ la Corte encuentra acreditado que al momento de la detención inicial a la señora J. le vendaron los ojos, la golpearon, la manosearon sexualmente y la mantuvieron en un automóvil durante un tiempo indeterminado, así también considera razonable presumir que durante los traslados continuó siendo amenazada por los agentes estatales que la detuvieron. Por lo que concluye que la señora J. sufrió diversos malos tratos.

Una vez determinados los maltratos la Corte analiza la calificación jurídica de los hechos ${ }^{\mathbf{2 6 0}}$ respecto a si lo manoseos constituyen violencia sexual o violación sexual y su calificación como tortura.

Para aclarar la diferencia entre violencia sexual y violación sexual, se remite a los estándares empleados por el Tribunal Penal Internacional para la ex Yugoslavia en el caso Furundzija y a la sentencia del caso Penal Miguel Castro Castro contra Perú, en el sentido de que por violación sexual deben entenderse los actos de penetración vaginal o anal, sin consentimiento de la víctima mediante la utilización de otras partes del cuerpo del agresor u objetos, así como penetración bucal mediante el miembro viril, y que es suficiente que se produzca una penetración por insignificante que sea. ${ }^{261} \mathrm{Y}$ resulta trascendental la interpretación que hace la Corte de la concepción de que "se produzca una penetración por insignificante que sea" al aclarar que:

“...se debe entender que la penetración vaginal se refiere a la penetración, con cualquier parte del cuerpo del agresor u objetos, de cualquier orificio genital, incluyendo los labios mayores y menores, así como el orificio vaginal."262

Con tales elementos la Corte concluye que en el presento caso el manoseo perpetrado a la señora J., implicó una invasión física de su cuerpo y al involucrar el área genital significó que el mismo fue de naturaleza sexual, así como que debido a las circunstancias en la que se

\footnotetext{
${ }^{259}$ Ibíd., párr. 354-356

${ }^{260}$ Ibíd., párr.357-368

${ }^{261}$ ColDH, Caso Penal Castro Castro Vs. Perú, op. cit., párr. 310 y TPIY, Caso Furundzija, op. cit., párr. 185, citados por CoIDH, Caso J. vs. Perú, op. cit., párr. 359

${ }^{262}$ ColDH, Caso J. vs. Perú, op. cit., párr. 359
} 
originaron los hechos eliminan cualquier posibilidad que hubiese consentimiento, por lo que el manoseo constituyó violencia sexual y que debido a las declaraciones de la presunta víctima (que solo refieren que fue manoseada sexualmente) que constan en el expediente no es posible determinar si dicha violencia sexual además constituyó violación sexual, conforme a los estándares ya señalados.

Posteriormente la Corte entra al estudio sobre la determinación de posibles actos de tortura y otros tratos crueles, inhumanos o degradantes, donde consideró que dicha violencia sexual fue un acto denigrante y humillante tanto física, como emocionalmente, que pudo haber causado consecuencias psicológicas severas para la víctima, que la violencia sexual constituye una violación al derecho a la integridad personal que tiene diversas connotaciones de grado y abarca desde la tortura hasta otro tipo de vejámenes o tratos crueles, inhumanos o degradantes, cuyas secuelas varían de intensidad según factores endógenos y exógenos de la persona y que deben analizarse en cada situación concreta. Asimismo reitera por un lado los elementos que configuran la tortura: la intencionalidad, los sufrimientos físicos o mentales y la finalidad, y por el otro que la tortura psicológica puede constituirse a través de las amenazas y el peligro real de someter a una persona a lesiones físicas, que en determinadas circunstancias producen una angustia moral.

Con estos estándares la Corte determina que “...al haber estado vendada, la señora J. debió haber estado desorientada lo cual probablemente aumentó su grado de angustia y terror sobre lo que podría suceder. Estos sentimientos se intensificaron cuando la señora J. fue conducida por algún tiempo sin destino conocido, cuando es presumible que fue amenazada por funcionarios policiales, sin ningún tipo de garantía legal. Dentro de este contexto, al haber sido detenida mediante la fuerza, y tras haber sido víctima de una violencia sexual, para la señora J. existía un riesgo real e inmediato de que dichas amenazas se concretasen..."263 Y concluye que los maltratos a los que fue sometida constituyen una violación al artículo 5.2 de la CADH que establece la prohibición tanto de la tortura, como de otros tratos crueles, inhumanos o degradantes.

\footnotetext{
${ }^{263}$ Ibíd., párr. 365
} 
Es de observarse que la Corte no especifica si la violación al artículo 5.2 de la CADH se debió en específico por actos constitutivos de tortura o bien por actos constitutivos de tratos crueles, inhumanos o degradantes, sin embargo de acuerdo a su análisis previo es de presumirse que la Corte tipificó dicha violencia sexual aunada a otra serie de actos (el haber sido vendada, detenida y amenazada) como tortura psicológica.

Posteriormente la Corte tipifica también la violencia sexual como una violación al derecho a la honra y la dignidad, establecido en el artículo 11 de la Convención, y que a su vez enmarca el derecho a la vida privada.

Finalmente la Corte concluye que el Estado es responsable por la violación a los derechos a la integridad personal, a la dignidad y a la vida privada, consagrados en los artículos 5.1, 5.2, 11.1 y 11.2 de la $\mathrm{CADH}$, en relación con el artículo 1.1 del mismo tratado y 6 de la Convención Interamericana contra la Tortura. Así también es responsable por el incumplimiento del deber establecido en el artículo 7b de la Convención Belém do Pará y los artículos 6 y 8 de la Convención Interamericana contra la Tortura, al no haber investigado las violaciones a derechos humanos ya mencionadas.

\subsubsection{Análisis de los principales aportes de la sentencia}

La presente sentencia es un precedente de suma importancia en materia de violencia sexual vinculada a la obligación de investigar por parte del Estado.

En este sentido, la Corte refuerza los estándares fijados en los casos de Inés Fernández y Valentina Rosendo contra México, relacionados a la prohibición de exigencia de pruebas gráficas o documentales para la investigación de violaciones sexuales, siendo fundamental la declaración de la víctima, extendiendo el ámbito de protección de dicho criterio a otros tipos de violencia sexual, como el manoseo sexual del presente caso, y reafirma que estos actos de violencia es frecuente que no dejen marcas ni cicatrices.

Sin embargo, lo más interesante en este último precepto es que deja en responsabilidad del Estado la carga de la prueba, al manifestar que si no se realizaron otros exámenes para 
acreditar los malos tratos es imputable al Estado y que no puede usarse tal situación para desvirtuar lo declarado por la víctima, otorgándole así pleno valor probatorio a la declaración de ésta, pero sobretodo aclarando que la investigación no puede depender de la actividad procesal de las víctimas, sino que es un deber jurídico propio de las autoridades. Tal aseveración es sustancial para la defensa de los derechos humanos de las mujeres, pues en el marco de la administración e impartición de justicia, es común que los operadores de justicia dejen la carga de la prueba a la víctima, sin asumir su responsabilidad en la investigación de los hechos y sin asumirlo como un deber jurídico propio, lo que se refleja en la dilación de la administración de justicia, donde los investigadores no realizan diligencias por iniciativa propia, sino hasta cuando las víctimas ejercen presión.

Otro aspecto de gran interés son los estándares que fija la Corte para investigar hechos de violencia sexual en el marco de la debida diligencia, estableciendo una serie de criterios como el ambiente cómodo, privado y seguro donde se tome la declaración de la víctima; el registro de la declaración para evitar la repetición de ésta; la atención integral, de urgencia y continua que debe brindarse a la víctima; la realización inmediata de los exámenes por personal calificado y de preferencia del mismo sexo; y la documentación de las investigaciones y custodia de las pruebas.

Todos estos estándares jurisprudenciales de actuación son de suma importancia en la defensa de casos de violencia contra las mujeres, pues permiten exigir su cumplimiento por parte de las autoridades en la marco de la debida diligencia, ya que es muy común que debido a la falta de sensibilidad y profesionalidad de los operadores de justicia, se tomen las declaraciones de las víctimas en oficinas abiertas al público, que no se garantice la realización inmediata de exámenes y certificados, bajo la justificación de la carga de trabajo, personal o recursos y por lo general no se brinda atención integral continua, ya que en el marco de la administración de justicia es frecuente que sólo se realicen los dictámenes psicológicos en el marco de la investigación y con ello querer justificar que se ha brindado la atención integral. 
Todas estas irregularidades obstaculizan el acceso a la justicia para las víctimas de violencia sexual y las re victimizan, por lo que es indispensable exigir a las autoridades el cumplimiento de sus obligaciones en materia de derechos humanos de las mujeres, y en particular en casos de violencia sexual.

Con relación al tipo de justificaciones que ponen los operadores de justicia respecto a lo no investigación de los hechos y la concepción de tales autoridades respecto a la falta de veracidad de las declaraciones de las víctimas de violencia sexual, la Corte también fijó estándares importantes en el presente caso, en el sentido que desde que se tiene conocimiento de un acto de violencia es obligación del Estado investigar de forma seria, imparcial y efectiva, y que tal investigación no puede estar condicionada por quien realiza la denuncia o por la creencia de las autoridades respecto a la falsedad de las declaraciones. Tal estándar permite observar los prejuicios de género de las autoridades, que merman una investigación en el marco de la debida diligencia, obstaculizando así el acceso a la justicia para las víctimas de violencia sexual. Estándar que refuerza la justicia de género por parte de la Corte, al hacer frente al componente estructural y al políticocultural del fenómeno jurídico permeado por estereotipos y prejuicios de género.

Respecto a la tipificación de la violencia sexual, la Corte en el presente caso sigue avanzando a través de la clasificación de diversos tipos de violencia sexual, en este caso el manoseo sexual lo configuro como violencia sexual (al no tener elementos para determinar si además se podría configurar una violación sexual), la cual al estar aunada a otra serie de actos (golpes, vendado de ojos y amenazas) constituyó malos tratos. En este apartado es importante mencionar que la Corte se nutre nuevamente de los precedentes jurisprudenciales de los Tribunales Penales Internacionales ad hoc, en este caso el de la ex Yugoslavia, en el caso Furundzija para remitirse a las características de la violación sexual.

La Corte sigue avanzando en la configuración de la violencia sexual, analizándola en el marco del contexto, es decir, los sufrimientos físicos y mentales ocasionados a la víctima; que fue detenida mediante la fuerza; las amenazas que sufrió; el riesgo real e inmediato 
de que las amenazas de concretaran; y como las amenazas y peligro real de someter a una persona a lesiones físicas constituye tortura psicológica, de tal suerte, que concluye que todos estos maltratos fueron violatorios al artículo 5.2 de la $\mathrm{CADH}$, de lo que se percibe que tipificó la violencia sexual como constitutiva de tortura psicológica.

De esta forma puede observarse como los estándares del Sistema Interamericano siguen consolidándose, existiendo mayores precedentes que permiten clasificar distintos tipos de violencia sexual, pero también observando que cada tipo de violencia sexual a la que es sometida una mujer debe ser analizada en el marco del contexto y de las circunstancias que rodean dicho acto de violencia, pues un acto de violencia sexual podrá variar según las circunstancias propias del caso y las características particulares de la víctima, pudiéndose configurar como tortura ya sea física o psicológica, o bien como trato cruel, inhumano o degradante. Lo que permite observar el trabajo del Tribunal por la justicia de género al tomar en cuenta las características particulares de la víctima y del contexto, en contraposición a una justicia totalitarista que desconoce las razones de género que requieren una atención especializada.

Es por ello que estos estándares jurisprudenciales son de gran apoyo para la defensa y fundamentación de casos concretos, logrando así la nutrición de los sistemas jurídicos internos. Por último es importante referir la aplicación de la Convención de Belém do Pará en el presente caso para determinar la responsabilidad estatal. 


\section{Capítulo IV}

\section{La justicia de género en el Sistema de Naciones Unidas}

La Organización de las Naciones Unidas fue conformada en 1945 a consecuencia de las atrocidades cometidas durante la Segunda Guerra Mundial y bajo el compromiso de los Países de mantener la paz y seguridad internacional. El instrumento fundacional del Sistema fue la Carta de las Naciones Unidas que se adoptó en San Francisco, Estados Unidos, en junio de 1945 y entró en vigor en octubre del mismo año.

Con la Carta se crea la Corte Internacional de Justicia y un Consejo Económico y Social (ECOSOC) con la facultad de crear comisiones que promovieran los derechos Humanos. De esta forma el ECOSOC crea en 1946 una Comisión de Derechos Humanos (la cual fue reemplazada en 2006 por la figura del Consejo de Derechos Humanos).

La Comisión de Derechos Humanos trabajó en la elaboración de un instrumento internacional, que posteriormente fue aprobado el 10 de diciembre de 1948 en París como la Declaración Universal de Derechos del Hombre, ${ }^{264}$ sin embargo, Eleanor Roosevelt (presidenta del Comité de Redacción de la Declaración) fue precursora de que se empleara un término incluyente (tanto en el título, como en el contenido), de tal suerte, que el título se modificó por Declaración Universal de Derechos Humanos, la cual contiene un catálogo enunciativo de 30 derechos civiles, políticos, económicos, sociales y culturales y hace referencia a todos los seres humanos.

En sentido teórico, este instrumento carecería de carácter vinculante, por tratarse de una Declaración, sin embargo, en 1968, en el marco de la Conferencia Internacional de Derechos Humanos de Teherán, los Países aceptaron su obligatoriedad, por ser la fuente del sistema internacional de derechos humanos.

\footnotetext{
${ }^{264}$ Véase el texto original en: http://www.un.org/es/comun/docs/?symbol=A/RES/217(III)
} 
La declaración es el punto de partida de los derechos humanos a nivel universal, pues es la primera vez que mediante un documento de carácter mundial se reconocen los derechos humanos. Sin embargo, ante la necesidad de crear un instrumento que además de contener un listado de derechos humanos, contemplara obligaciones para los Estados y mecanismos de supervisión de los derechos humanos, el 16 de diciembre de 1966 se adoptó el PIDCP en Nueva York, el cual entró en vigor el 23 de marzo de 1976.

Con la entrada en vigor del PIDCP se crea un Comité de Derechos Humanos, encargado de supervisar el cumplimiento del mismo, para ello tiene competencia de conocer comunicaciones entre Estados Parte, cuando uno alegue que otro Estado no cumple con las obligaciones impuestas por el Pacto, siempre y cuando ambos Estados hayan aceptado la competencia del Comité para recibir y examinar peticiones.

Asimismo prevé un sistema de informes, mediante el cual los Estados deberán presentar en el plazo de un año (a partir de la fecha de entrada en vigor) un informe sobre las disposiciones que hubieren adoptado para dar cumplimiento al Pacto y hacer efectivos los derechos reconocidos y el progreso en cuanto al goce de éstos. En lo sucesivo el informe se presentará cada vez que así lo solicite el Comité.

El mismo 16 de diciembre de 1966 se adoptó el primer Protocolo Facultativo del Pacto Internacional de Derechos Civiles y Políticos, el cual también entró en vigor el 23 de marzo de 1976 y faculta al Comité de Derechos Humanos para recibir comunicaciones de personas que aleguen ser víctimas de violaciones de los derechos humanos enunciados en el Pacto, estableciendo el procedimiento para la recepción y admisibilidad de las mismas.

Sin embargo, en materia de comunicaciones por violencia sexual contra mujeres como método de tortura, sería el Comité contra la Tortura el competente para resolver. Éste se crea mediante la adopción y entrada en vigor de la Convención Contra la Tortura y Otros Tratos o Penas Crueles, Inhumanos o Degradantes, en virtud del artículo 17, y entra en funciones el $1^{\circ}$ de enero de 1988. 
El Comité tiene competencia de acuerdo al artículo 22 de la Convención para recibir y examinar comunicaciones enviadas por personas que aleguen ser víctimas de una violación a las disposiciones de la Convención por un Estado parte, para lo cual el Estado de que se trate debió haber reconocido mediante declaratoria la competencia del Comité.

Así también, la CEDAW establece la creación de un Comité encargado de supervisar el cumplimiento de la Convención; el Comité para la Eliminación de la Discriminación contra la Mujer, para lo cual los Estados Parte se comprometen a rendir un informe sobre las medidas legislativas, judiciales, administrativas o de otra índole que hayan adoptado para hacer efectivas las disposiciones de la Convención, en el plazo de un año a partir de la entrada en vigor de la misma y en los sucesivo por lo menos cada cuatro años, o cada vez que el Comité lo requiera.

Con la adopción del Protocolo Facultativo a la Convención sobre la Eliminación de todas las formas de Discriminación contra la Mujer, el 06 de octubre de 1999, se dota de competencia al Comité para examinar comunicaciones presentadas por personas que aleguen ser víctimas de una violación de los derechos enunciados en la Convención, asimismo podrá conocer de violaciones graves o sistemáticas a los derechos enunciados en un Estado.

En este sentido, el Comité CEDAW podría conocer de asuntos de violencia sexual contra mujeres como método de tortura, a partir de interdependencia entra la discriminación y la violencia contra las mujeres, sin embargo la mayoría de las comunicaciones resueltas versan sobre situaciones de discriminación en distintos ámbitos y violencia familiar.

De esta forma, a través de la resolución de comunicaciones individuales por parte de los Comités creados en virtud de los tratados, se han creado estándares en la protección de los derechos humanos, sin embargo, se ubicó un sólo caso de interés para la presente investigación, relacionado a actos de violencia sexual como método de tortura y resuelto por el Comité contra la Tortura, donde el examen de fondo versa sobre violaciones al debido proceso. 
El mismo Comité ha resuelto casos de mujeres pero por peticiones que alegan que la extradición, repatriación o deportación implicaría una violación al artículo 3 de la Convención, por la posibilidad de ser sometidas a tortura. ${ }^{265}$ Con relación a estos casos destacan la Comunicación № 279/2005 del caso C.T. y K.M. Vs. Suecia, donde el Comité considera que la autora fue violada varias veces en prisión, lo que constituye tortura, y que su hijo es el fruto de la violación por funcionarios públicos, lo que significa un recordatorio constante de que fue violada, sin embargo no entra a mayor estudio respecto a la violación sexual como constitutiva de tortura, de igual forma que en la comunicación № 262/2005 del caso V.L. Vs. Suiza, donde el Comité establece que los abusos sexuales cometidos por la policía constituyen tortura, independientemente de que hayan sido perpetrados fuera de los locales oficiales de detención y agrega que:

"Es un hecho bien conocido que la pérdida de intimidad, sumado a la perspectiva de sentir humillación solo porque se revelan determinados actos, puede hacer que tanto mujeres como hombres oculten el hecho de que han sido objeto de violación $\mathrm{y} / \mathrm{u}$ otras formas de abuso sexual hasta que sea absolutamente necesario revelarlo. En el caso particular de las mujeres, existe el miedo adicional de la vergüenza y el rechazo de su pareja o familiares. "266

Sin embargo, ambos casos no profundizan en mayor medida de lo ya mencionado con relación a la violencia sexual y tortura, por lo que se analiza únicamente el caso relativo a las violaciones al debido proceso por aportar estándares sustanciales respecto a la obligación estatal de investigar y sancionar actos de violencia sexual contra mujeres como método de tortura.

\footnotetext{
${ }^{265}$ Véase Caso Cecilia Rosana Núñez Vs Venezuela, Comunicado N 110/1998 del 16 de diciembre de 1998, Caso A.S. Vs Suecia, Comunicado No 149/1999 del 15 de febrero de 2001, Caso V.L. Vs. Suiza, Comunicación № 262/2005 del 20 de noviembre de 2006, Caso C. T. y K. M. Vs. Suecia, Comunicación № 279/2005 del 17 de noviembre de 2006 y Caso T.A. y S.T. Vs Suecia, Comunicado № 226/2003 del 27 de mayo de 2005.

${ }^{266}$ ONU, Comité contra la tortura, Caso V.L. Vs. Suiza, Comunicación № 262/2005 del 20 de noviembre de 2006, párr.8.8
} 


\section{Comité contra la Tortura}

Caso Encarnación Blanco Abad v. España, Comunicado № 59/1996

(Tortura y malos tratos presuntamente atribuibles a la Guardia Civil)

14 de mayo de 1998

La señora Encarnación Blanco Abad presentó por primera vez al Comité la Comunicación No. 10/1993, sin embargo fue declarada inadmisible el 14 de noviembre de 1994 por la falta de agotamiento de los recursos internos. Posteriormente el 12 de febrero de 1996 presentó la comunicación No. 59/1996, declarándose admisible el 28 de abril de 1997, resolviéndose el 14 de mayo de 1998.

\subsection{Resumen de los hechos.}

La señora Encarnación Blanco Abad, ciudadana española fue detenida junto con su esposo Josu Eguskiza el 29 de enero de 1992 por personal de la Guardia Civil, por sus presuntas implicaciones en actividades en favor de la banda armada Euskadi Ta Askatasuna (ETA). La Sra. Encarnación alega que fue sometida a malos tratos entre el 29 enero y el 2 febrero de 1992, período en que permaneció incomunicada en aplicación de la legislación antiterrorista en España.

La señora Encarnación alegó que fue víctima de malos tratos y tortura por elementos de la Guardia Civil de España, durante su estancia en tal dependencia, relatando que:

“... había sido golpeada con un listín telefónico, le habían aplicado bolsa y electrodos, obligado a desnudarse y amenazado con ser violada. Mientras permanecía con los brazos levantados y las piernas abiertas contra una pared, de vez en cuando la golpeaban en la cabeza y órganos genitales, habiendo recibido además todo tipo de insultos. "267

\footnotetext{
${ }^{267}$ ONU, Comité contra la Tortura, Caso Encarnación Blanco Abad Vs. España, Comunicación № 59/1996, Párr. 4.3
} 
En específico manifestó haber sido víctima de violaciones a los artículos 12, 13 y 15 de la Convención contra la Tortura y Otros Tratos o Penas Crueles, Inhumanos o Degradantes, referentes a la obligación del Estado de iniciar una investigación pronta e imparcial por las autoridades competentes, al derecho de las víctimas de tortura a interponer una queja y a la prohibición de que toda declaración obtenida bajo tortura sea invocada como prueba de un procedimiento.

\subsection{Resolución del Comité contra la Tortura}

Toda vez que la comunicación se presentó al Comité por violaciones a los artículos 12, 13 y 15 de la Convención, es decir aquellas relacionadas a la investigación de los hechos, más no por violaciones al derecho a la integridad personal y en específico al derecho a no ser sometida a tortura, la resolución del Comité más allá de analizar o pronunciarse respecto a la acreditación de la violencia sexual, el desnudamiento forzado y las amenazas de violación, como actos constitutivos de tortura, analiza la falta de investigación de los hechos por parte del Estado, generando estándares de protección al respecto.

En este sentido, el Comité al analizar las violaciones alegadas al artículo 12, observa que el Estado tuvo elementos para investigar desde la comparecencia de la agraviada ante el juez de la Audiencia Nacional, el 2 de febrero de 1992, donde ésta declaró haber sido sometida a malos tratos físicos y mentales, incluida la amenaza de violación, momento en que el juez tenía ante sí cinco informes médicos forenses, previos a la comparecencia, donde consta que la agraviada refirió haber sido víctima de tortura, aunque no presentaba señales de violencia. El Comité determina que estos elementos deberían haber sido suficientes para que se iniciara una investigación, lo que sin embargo no tuvo lugar. De igual forma refiere que el 3 de febrero el médico del centro penitenciario constató hematomas y contusiones en el cuerpo de la Sra. Encarnación, poniéndolo a conocimiento de las autoridades judiciales, sin embargo el juzgado competente recibió el caso el 17 de febrero y se iniciaron diligencias hasta el 21 de febrero, situaciones que acreditan la falta de investigación y el lapso de tiempo transcurrido entre la denuncia de los hechos y la 
apertura de diligencias, resultando incompatible con la obligación de proceder a una pronta investigación prevista en el artículo 12 de la Convención ${ }^{268}$.

Respecto a la obligación del Estado de investigar de forma pronta e imparcial, el Comité genera estándares que amplían el ámbito de protección e interpretación respecto a la prontitud en la investigación, con relación a los efectos en la víctima de tortura o malos tratos, al determinar que:

"Con respecto a la prontitud, el Comité observa que la misma es esencial, tanto para evitar que la víctima pueda continuar siendo sometida a los actos mencionados como por el hecho de que, salvo que produzcan efectos permanentes y graves, en general, por los métodos empleados para su aplicación, las huellas físicas de la tortura y, con mayor razón, de los tratos crueles, inhumanos o degradantes, desaparecen en corto plazo."169

Por otra parte al analizar las violaciones alegadas al artículo 13, el Comité amplió de igual forma el ámbito de interpretación del derecho de las víctimas a interponer una queja por actos de tortura, al determinar que:

“... el artículo 13 de la Convención no exige la presentación formal de una denuncia por tortura formulada según el procedimiento previsto en la legislación interna, ni requiere expresa declaración de la voluntad de ejercer y sostener la acción penal que emana del delito, sino que es suficiente la simple manifestación de la víctima que pone los hechos en conocimiento de una autoridad del Estado, para que surja para éste la obligación de considerarla como tácita pero inequívoca expresión de su deseo de que ellos sean pronta e imparcialmente investigados, como prescribe esta disposición de la Convención."270

Con dicho estándar concluye que la queja de la agraviada interpuesta ante el Juez de la audiencia Nacional no fue examinada y que el Juzgado No. 44, si bien la examinó, no lo

\footnotetext{
${ }^{268}$ Ibídem, párr. 8.3, 8.4 y 8.5

${ }^{269}$ Ibíd. párr. 8.2

${ }^{270}$ Ibíd. párr. 8.6
} 
hizo con la prontitud requerida, pues transcurrió un lapso mayor a tres semanas desde la recepción del reconocimiento médico el 17 de febrero de 1992, hasta que la agraviada fue llevada a presencia judicial el 13 de marzo del mismo año. De igual forma el Comité denotó una serie de dilaciones en la práctica de diligencias de la investigación, por lo que consideró que la cronología de las investigaciones reveló una actividad investigativa que no satisface la prontitud en el examen de las quejas que prescribe el artículo 13 de la Convención, defecto que no puede excusarse en la ausencia de protesta de la autora por esa prolongada tardanza. Asimismo, constató la negativa de las autoridades judiciales a practicar pruebas y, en particular, las propuestas por la autora. ${ }^{271}$

Por lo anterior, el Comité consideró que las omisiones referidas resultan incompatibles con la obligación de proceder a una investigación imparcial prevista en el artículo 13 de la Convención.

Respecto a la alegación de la Sra. Encarnación referente a que su condena era una violación del artículo 15 de la convención, el Comité en el examen sobre la admisibilidad observó que la sentencia de la Audiencia Nacional señaló que las declaraciones de los procesados ante la policía, incluida la de la autora, no habían sido tomadas en consideración por la posible existencia de torturas, y que la condena fue fundada en otras declaraciones, por lo que el Comité decidió que la reclamación de violación al artículo 15 carecía de un mínimo de corroboración y resultaba incompatible con el artículo 22 de la Convención, por lo que determinó que la comunicación era admisible en lo referente a las violaciones alegadas de los artículos 12 y 13 de la Convención. ${ }^{272}$

\subsection{Análisis de los principales aportes de la resolución}

Como puede observarse la presente resolución no entra al estudio concreto de la violencia sexual como constitutiva de tortura, a diferencia del Sistema Interamericano de Derechos Humanos. Si bien la comunicación se presentó por violaciones a los artículos 12, 13 y 15

\footnotetext{
${ }^{271}$ Ibíd. párr. 8.7 y 8.8

${ }^{272}$ Ibíd. párr. 5.3
} 
de la Convención contra la Tortura, y no como tal por los hechos de tortura, considero que el Comité pudo haber suplido la deficiencia de queja y enriquecer la resolución mediante un análisis de los hechos de violencia sexual como constitutivos de tortura.

Sin embargo, dentro de los aportes sustanciales de la resolución pueden ubicarse aquellos vinculados a la obligación de investigar la tortura por parte de las autoridades.

En este sentido destaca el estándar fijado por el Comité con relación a la prontitud de las investigaciones, la cual es esencial tanto para evitar la continuidad de los actos, como por el hecho de que las huellas de tortura o de tratos crueles, inhumanos o degradantes desaparecen a corto plazo.

Tal estándar es de suma importancia en la defensa de los derechos humanos de las mujeres, pues como se ha mencionado, generalmente los operadores de justicia buscan acreditar la tortura mediante huellas de violencia física, sin tomar en cuenta que los perpetradores de la tortura estratégicamente golpean zonas del cuerpo o emplean mecanismos que no dejan huellas físicas. Aunado a la falta de visualización de los efectos psicológicos, morales y sociales de tales actos.

Otro estándar importante lo fija al establecer que basta con que la víctima haga de conocimiento los hechos a una autoridad, para que se inicie la investigación en el marco de las obligaciones de las autoridades, es decir, sin necesidad de presentación formal de denuncia por parte de la víctima o declaración de su voluntad a iniciar acción penal.

De esta forma, el Comité observa que no hacen falta las formalidades que en muchas ocasiones se exigen por los operadores de justicia, formalidades que justifican su falta de sensibilidad de género y la inoperatividad en la investigación, donde dejan en manos de las víctimas la actividad procesal, sin asumirlo como un deber jurídico propio derivado de sus obligaciones en materia de derechos humanos. 
Desafortunadamente no se ubicaron más casos ni el Comité de Derechos Humanos que tiene la facultad de conocer comunicaciones por violaciones al artículo 7 del PIDCP, ni en el Comité CEDAW que podría conocer comunicaciones por violaciones al derecho a la no discriminación, el cual de acuerdo a la Recomendación General 19 del mismo Comité incluye la violencia contra la mujer. Aunque esto puede deberse a que el Comité especializado para conocer de hechos de tortura $u$ otros tratos o penas crueles, inhumanos o degradantes, es el creado en virtud de la Convención contra la Tortura de la ONU. 


\section{Conclusiones}

Del presente análisis y sistematización puede observarse el acervo jurídico internacional de protección a los derechos humanos de las mujeres y extensible a la protección de actos de violencia sexual constitutivos de tortura. Destaca la evolución histórica de los instrumentos internacionales de protección, desde aquellos de carácter genérico, hasta los específicos que constituyen la Carta de los Derechos Humanos de las Mujeres; La Convención sobre la Eliminación de todas las formas de Discriminación contra la Mujer y la Convención Interamericana para Prevenir, Sancionar y Erradicar la Violencia contra la Mujer. Estas últimas generando una serie de obligaciones de carácter específico para los Estados.

Puede observarse como dos fenómenos históricos y estructurales; la violencia y la discriminación hacia las mujeres, hicieron frente a los Organismos Internacionales de Protección a los Derechos Humanos, tanto a nivel universal, como regional o interamericano, para abordar la necesidad de proveer una protección específica a las mujeres, que debido a la desigualdad histórica arraigada en el binomio sexo-género las coloca en situaciones de vulnerabilidad frente a el goce, ejercicio y garantía de los derechos humanos.

Así también resulta sustancial recoger como antecedentes importantes para la tipificación de la violencia sexual como tortura, los fallos de los Tribunales Penales Internacionales para la ex Yugoslavia y Ruanda, los cuales significan precedentes y esfuerzos importantes por proveer estándares jurisprudenciales que permiten visibilizar tal equiparación. La construcción y avance de conceptos relativos a la violencia sexual y violación sexual por parte de estos Tribunales son referentes importantes, donde destaca el avance por liberar de la definición de violencia sexual los actos mecánicos y la coerción física, desarrollándose así, otras circunstancias capaces de permear la voluntad de las víctimas, como lo es el contexto y la relación de poder o mando, que en sí constituyen coacción. 
La sentencia del caso Akayesu, como ya se ha mencionado, resulta un avance significativo en materia de protección a los derechos humanos de las mujeres, sobre todo el derecho a una vida libre de violencia, pues constituye la primera sentencia internacional que visibiliza y condena la violencia sexual contra mujeres como una acto de genocidio y de lesa humanidad, pero a su vez constitutivo de tortura. De igual forma, implicó un avance sustancial para la ampliación de la definición de la violencia sexual, desligando de la penetración y de la descripción mecánica de objetos y partes del cuerpo, permitiendo así, que otros actos de naturaleza sexual invasiva pudieran ser constitutivos de violencia sexual, como es la desnudez forzada.

Tal sentencia permite a su vez, desligar de las circunstancias coercitivas la demostración de la fuerza física, visualizando otros mecanismos de coacción que por razones de género que colocan a las mujeres en situación de vulnerabilidad frente a la violencia, entre ellos las relaciones desiguales de poder y sus efectos sobre la víctima.

Con tales precedentes jurisprudenciales puede apreciarse la aplicación de la justicia de género por parte del Tribunal, al tomar en cuenta las características particulares de las víctimas, asociadas a la condición de género, lo que permitió al Tribunal proveer una protección especial a las víctimas.

Por su parte, la sentencia del caso Furundzija sigue avanzando en la justicia de género al agregar en los elementos de la tortura la humillación como un atentado a la dignidad humana, considerando así los efectos de la violencia sexual en las mujeres, asociados a su rol de género y las consecuencias sociales por los patrones socioculturales de conducta asociados a hombres y mujeres.

Asimismo el Tribunal agrega a la configuración de la violencia sexual el elemento de la amenaza de la fuerza, la cual puede ser explícita o implícita e infundir miedo a la víctima de que ella o un tercero puedan ser sometidas a violencia u opresión psicológica, con lo que sigue avanzando en la tipificación de tal figura, reconociendo así la existencia de otros 
factores de opresión para lograr la violación sexual. Argumenta también el vicio del consentimiento de la víctima derivado de la condición de cautiverio.

De tal suerte el Tribunal a través de una impartición de justicia de género, avanza en el reconocimiento de las características específicas de las víctimas y el contexto, asociadas a la violencia sexual, que deben observarse en la defensa de los derechos humanos de las mujeres.

La sentencia del caso Dragoljub Kunarac, Radomir Kovac y Zoran Vukovic retoma la definición aportada en el caso Furundzija, pero liberándola del requisito de la coacción, fuerza o amenaza de la fuerza, al establecer que éstos elementos no deben interpretarse de manera restrictiva, ya que la coacción abarca la mayor parte de la conducta que niega el consentimiento.

Lo anterior, resulta un aspecto importante en la evolución de la definición de la violación sexual, al desvincular el acto de penetración de los requisitos de coacción, fuerza o amenaza de la fuerza contra la víctima, pero sobretodo del requisito obsoleto e infundado de demostrar la oposición de resistencia (como obligatorio). Ello permite vincular y argumentar otros factores que colocan a las víctimas en situación de vulnerabilidad, como lo es el engaño, la intimidación por el cargo jerárquico o familiar del agresor y el contexto bajo el cual se cometen dichas violaciones u otras circunstancias que la hagan incapaz de resistir.

Otro aporte importante de este Tribunal, es el reconocimiento de los efectos de la violencia sexual, al establecer que la violación constituye uno de los peores sufrimientos que un ser humano puede infligir a otro y que dan lugar a dolores severos físicos y mentales

En el Sistema Interamericano de Derechos Humanos destaca el avance de las resoluciones y sentencias respecto a la tipificación de la violencia sexual (incluida la violación sexual) como constitutiva de tortura y otros tratos o penas crueles inhumanos y degradantes. 
Es de observarse que las primeras resoluciones de la Comisión Interamericana de Derechos Humanos en casos de violencia sexual contra mujeres, distan mucho de hacer un acercamiento de estos actos como constitutivos de tortura, se muestra también el poco o nulo análisis de género en tales determinaciones. Tales son los casos Rosa Marta Cerna Alfaro, Flor de María Hernández Rivas y Comadres, todos contra El Salvador, donde la violación sexual no fue analizada a profundidad, así como tampoco los elementos constitutivos de tortura, cuando mucho en algunos casos, capaz de extenderse a tratos crueles, inhumanos o degradantes, no se otorgó pleno valor probatorio a las declaraciones de las víctimas y no se empleaba ni en la interpretación, ni en la determinación de responsabilidad la Convención de Belén do Pará

El caso Raquel Martín de Mejía Vs. Perú marcó un hito importante en el Sistema Interamericano en cuanto a la tipificación de la violencia sexual como tortura, pero sobre todo por el contenido de análisis (incluido de género) por parte de la Comisión, siendo el primer asunto relativo a violencia sexual contra una mujer, en donde se analizan los elementos que deben conjugarse para acreditar la tortura y se hace referencia al ostracismo público, sin embargo, al igual que en los casos anteriores, no hace uso de la Convención de Belém do Para.

Posteriormente el caso Dianna Ortiz Vs. Guatemala refleja una resolución titubeante por parte de la Comisión, donde en cierta forma se contradice con los estándares de género ya fijados en el caso Raquel Martín de Mejía, pues en el caso Dianna en lo referente al encuadre de la violencia sexual (incluida la violación) como tortura, otorga mayor exigencia y valor a las pruebas, que a la declaración de la víctima, haciendo a un lado la figura de ostracismo público, la cual en el presente caso se agravaría por la condición de género y de religión.

Más adelante destacan los casos Ana, Beatriz y Celia González Pérez Vs. México y Gladys Carol Espinoza Gonzáles Vs. Perú, donde la Comisión sigue avanzando en su análisis y generación de estándares jurisprudenciales con enfoque de género, pero sobre todo comienza a aplicar instrumentos específicos de protección a los derechos de las mujeres, 
como lo es la Convención de Belém Do Pará, en la primera resolución únicamente a modo de argumentación, pero en la segunda para determinar violaciones e incumplimiento de la misma.

En el primer caso destacan los principios que deben acatar los profesionales médicos en la investigación de denuncias de tortura, pero sobretodo su vínculo con el examen médico practicado a las víctimas, al cual no se le otorgó valor por parte de la justicia militar, a pesar de cumplir con los requisitos referidos por los principios. Con tal aporte la Comisión en el marco de la justicia de género, hace frente a circunstancias donde se coloca a las mujeres en situaciones de re victimización al tener que volver a someterse a un examen ginecológico que resulta invasivo para ellas, dadas las circunstancias de la violencia sexual.

En el caso Gladys Vs Perú, resulta de interés que la Comisión haga mención de la intencionalidad como un elemento más de la tortura refiriendo el caso Raquel Martín de Mejía, en donde la misma Comisión había vinculado de forma implícita la intencionalidad en el marco de la finalidad.

La resolución permite observar la nutrición del Sistema Interamericano a través de las interpretaciones y estándares jurisprudenciales emitidas por el mismo Sistema, pero a su vez por los precedentes jurisprudenciales de los Tribunales ad hoc. Es importante la equiparación de la incomunicación como trato cruel, inhumano y degradante, pues significa un avance en la distinción de algunos de los actos que pueden tipificarse bajo esta figura y que se distinguen de la tortura. Y sobre todo, se hace referencia a la violación del artículo 5.2 de la $\mathrm{CADH}$, marcando así un cambio formal y de fondo en las determinaciones de la Comisión y su posición en el reconocimiento de responsabilidad internacional por actos de tortura.

Por otro lado, en la sentencias de la Corte Interamericana de Derechos Humanos podemos observar de igual forma, un avance en materia de análisis de género y generación de estándares jurisprudenciales para la protección de los derechos humanos de las mujeres. 
En el primer caso analizado, Loayza Tamayo Vs. Perú, a pesar de la estrecha relación y coincidencia de lo declarado en los testimonios; donde se acredita que las personas detenidas eran llevadas a la playa para ser torturadas y se ubica a Loayza Tamayo en la playa, pudiéndose así vincular lo declarado por la víctima respecto a su violación sexual, la Corte considera que no existen elementos para acreditar la violación sexual, pasando por alto la especificidad de la violencia de género, donde ésta es empleada de forma diferenciada contra las mujeres, como un mecanismo de poder y de tortura para la obtención de confesiones.

Más adelante, el caso Penal Castro Castro Vs. Perú es fundamental por su alto análisis de género, tipificando la desnudez forzada a tratos crueles, inhumanos y degradantes, las amenazas constantes y el peligro real al que podían ser sometidas las internas como tortura psicológica y las inspecciones vaginales como constitutivas de tortura. Así también, en lo que respecta a la falta de acceso a la justicia para los familiares de las víctimas fallecidas, es el primer fallo de la Corte en que se determina el incumplimiento de las obligaciones adquiridas con la Convención de Belém Do Pará, en específico por su obligación de actuar con la debida diligencia para investigar, sancionar y reparar.

De igual forma, en los fallos contra México, González y Otras "Campo Algodonero", Valentina Rosendo Cantú e Inés Fernández Ortega, puede observarse el análisis progresista de género, estándares importantes en materia de tortura y la visualización de la violencia y discriminación contra las mujeres como parte de un contexto generalizado de violencia contra las mismas en Ciudad Juárez.

Sin embargo, en el caso Campo Algodonero la Corte no tipifica la violencia sexual a que fueron sometidas las víctimas como constitutiva de tortura, vacilando en cierta forma en su pronunciamiento y bajando de tono las agresiones cometidas contras las víctimas, pues de hacer mención en un primer momento a éstas como tortura, más adelante hace referencia a las mismas como tratos crueles. Aunque en este fallo habría que destacar el voto razonado de la entonces Jueza Cecilia Médina, quien aplica no sólo las normas de interpretación y el principio pro homine al equiparar los actos cometidos contra las 
víctimas como tortura, sino también el derecho internacional comparado a partir de la jurisprudencia.

Por su parte, en los casos Valentina Rosendo Cantú e Inés Fernández Ortega destaca la prohibición de exigencia de pruebas gráficas o documentales para la investigación de violaciones sexuales, siendo fundamental la declaración de la víctima.

Por último, el más reciente fallo de la Corte en materia de violencia sexual, es decir el caso J. Vs. Perú, contiene estándares importantes respecto a la violencia sexual y determina que los malos tratos a los que fue sometida la víctima, incluida la violencia sexual, constituyen tortura psicológica. En este caso la Corte refuerza los estándares fijados en los casos de Inés Fernández y Valentina Rosendo contra México, con relación a la prohibición de exigencia de pruebas gráficas o documentales, otorgando pleno valor a la declaración de la víctima, extendiendo el ámbito de protección de dicho criterio a otros tipos de violencia sexual, como el manoseo sexual.

En cuanto al Sistema de Naciones Unidas únicamente se analiza una resolución del Comité contra la Tortura (el caso Encarnación Blanco Abad Vs. España) que hace referencia a violaciones por la falta de investigación de los hechos de tortura por actos de violencia sexual, derivadas del incumplimiento de los artículos 12, 13 y 15 de la Convención contra la Tortura, más no se hace un estudio detallado de la tortura como tal y por ende de la violencia sexual a la que fue sometida la víctima, por lo que se considera que el Comité pudo haber suplido la deficiencia de queja y enriquecer la resolución mediante un análisis de los hechos de violencia sexual como constitutivos de tortura. Por ello, la resolución dista mucho de un análisis de género, lo cual puede deberse a la especialidad del Comité.

Sin embargo, en el presente caso no puede desconocerse el aporte del Comité en lo que refiere a la prevención de la tortura, y sobre todo a la obligación de investigar por parte del Estado, donde refiere la obligatoriedad de la prontitud de las investigaciones para evitar tanto la continuidad de los actos, como que las huellas desaparezcan a corto plazo. 
Asimismo destaca el estándar que establece que basta con que la víctima haga de conocimiento los hechos a una autoridad, para que se inicie la investigación, sin necesidad de presentación formal de denuncia por parte de la víctima o declaración de su voluntad a iniciar acción penal. Estándar que es de suma utilidad en la defensa de los casos de violencia sexual contra mujeres como método de tortura.

Los demás casos de mujeres resueltos por el Comité son por peticiones que alegan que la extradición, repatriación o deportación implicaría una violación al artículo 3 de la Convención, por la posibilidad de ser sometidas a tortura. De éstas destacan la Comunicación № 279/2005 del caso C.T. y K.M. Vs. Suecia y la Comunicación № 262/2005 del caso V.L. Vs. Suiza, sin embargo sus aportes en cuanto a la justicia de género son muy limitados, como ya se señaló en el capítulo correspondiente.

De igual forma, no fue posible detectar casos de violencia sexual como tortura en el Comité contra la Eliminación de todas las formas de Discriminación contra la Mujer, ubicándose únicamente casos vinculados al derecho a la igualdad y no discriminación, incluida la violencia contra las mujeres, pero en el ámbito familiar o laboral.

De las conclusiones anteriores puede observarse el inicio del avance jurisprudencial en los Tribunales Penales ad hoc, seguido del progreso generado mediante las interpretaciones y jurisprudencia del Sistema Interamericano de Derechos Humanos, pero sobretodo la posibilidad de sus Organismos para juzgar no sólo desde una perspectiva de derechos humanos, sino también desde un enfoque de género que toma en cuenta la especificidad de las violaciones a los derechos humanos de las mujeres en razón de su sexo y género; las características particulares de las víctimas y del contexto; que hace frente al componente normativo, estructural y político - cultural del fenómeno jurídico permeado por prejuicios de género, contrarrestando así las leyes discriminatorias, la interpretación y aplicación de la leyes y la esencia que se le da a las mismas en las jurisdicciones internas; que garantiza la igualdad a partir de las diferencias del binomio sexo-género; y que da un enfoque transversal al derecho a la igualdad y no discriminación en sus determinaciones. 
Todos los instrumentos, criterios de interpretación y estándares jurisprudenciales analizados proveen una protección integral a las mujeres víctimas de violaciones a sus derechos humanos, en específico el derecho a una vida libre de violencia y discriminación. Son sumamente importantes y por ende deben ser conocidos para su debida aplicabilidad en la defensa adecuada de los derechos de las mujeres en el ámbito interno de los países.

En esta tesitura es importante recordar que en México a partir de la reforma constitucional en materia de derechos humanos, publicada el 10 de junio de 2011, todas las autoridades se encuentran obligadas a realizar una "interpretación conforme" a las normas de derechos humanos contempladas tanto en la Constitución Política, como en los Tratados Internacionales en materia de Derechos Humanos de los cuales el Estado Mexicano sea parte, con lo se abre la puerta a la aplicabilidad del Control de Convencionalidad fijado por la CoIDH y retomado como vinculante por la Suprema Corte de Justicia de la Nación a través de la emisión de una serie de tesis aisladas. Tales avances implican la obligatoriedad por parte de las autoridades de conocer y aplicar tanto los instrumentos internacionales, como la interpretación que de éstos hacen los Organismos Internacionales de Protección a los Derechos Humanos, facultados para ello.

Por lo anterior, concluyo la presente investigación convencida de que en la defensa de los derechos humanos de las mujeres y en la labor de la administración e impartición de justicia, deben conocerse los estándares fijados en materia de violencia sexual como constitutiva de tortura, para así, a través de su debida aplicabilidad proveer una protección más amplia a las víctimas. Además, tanto en México como en otros Países, el acceso al cuerpo de las mujeres a través la violencia sexual ha sido una herramienta de poder; una mala praxis para la obtención de confesiones y otros fines, tal como se ha observado en los casos analizados, donde en 4 de ellos se determinó la responsabilidad del Estado Mexicano. Sobre todo porque tal situación no dista de ser un asunto del pasado, ya que actualmente la Comisión Interamericana de Derechos Humanos se encuentra conociendo los hechos sucedidos en San Salvador de Atenco, México (Caso Mariana Selvas y otros Vs. México; Informe de Admisibilidad No. 158/11 del 02 de 
noviembre de 2011), donde se denuncian actos de violencia sexual en contra de 11 mujeres por agentes estatales, y donde se espera que dicho Organismo aplique los estándares jurisprudenciales fijados con anterioridad para proveer el acceso a la justicia que a las víctimas se les ha obstaculizado en el ámbito interno. 


\section{BIBLIOGRAFÍA}

ABS, da Cruz Rubia, La violencia sexual como una forma de tortura y expresión de poder sobre las mujeres, caso Castro Castro, CLADEM

ALIJA Fernández, Rosa Ana, Crímenes de Derecho Internacional y Derechos de la Mujer: De la protección del Honor a la Salvaguarda de la Libertad, en Colección Género, Derecho y Justicia: Derechos de las Mujeres en Derecho Internacional, coordinadores Juan A. Cruz Parcero y Rodolfo Vásquez, editorial fontamara, segunda edición, México, 2012

BUENO, Gonzalo, El concepto de tortura y de otros tratos crueles, inhumanos o degradantes en el Derecho Internacional de los Derechos Humanos, Editores del Puerto, Buenos Aires, Argentina, 2003

BUTLER, Judíth, Gender Trouble: Subjects of Sex / Gender /Desite, New York, Boutledge, 1990

Caucus de Mujeres por una Justicia de Género, Extracto de fallos relativos a violencia sexual, New York, en: www.iccwomen.org

Centro de Derechos Humanos Tlachinollan, Informe: Inés Fernández Ortega y Valentina Rosendo Cantú, cuando la lucha por acceder a la justicia no concluye, 2012

CEJIL, La tortura en derecho internacional, Guía de jurisprudencia, Publicación conjunta con la Asociación para la prevención de la Tortura (APT), 2008

, Instrumentos Internacionales para la Prevención y Sanción de la Tortura, Buenos Aires, Argentina, 2006

-----------, Los Derechos Humanos en el sistema Interamericano, Compilación de Instrumentos, Buenos Aires, Argentina, 2007

Comisión Mexicana de Defensa y Promoción de los Derechos Humanos, Violencia sexual: El otro rostro de la tortura, octubre 2012, en: http://cmdpdh.org/2012/10/violenciasexual-el-otro-rostro-de-la-tortura/

Comisión para el Esclarecimiento Histórico (CEH), GUATEMALA: Memoria del silencio, 1999

Comité sobre la eliminación de todas las formas de discriminación hacia la Mujer, Recomendaciones Generales, en: http://www.un.org/womenwatch/daw/cedaw/recommendations/recomm-sp.htm 
Constitución Política de los Estados Unidos Mexicanos, promulgada el 5 de febrero de 1917, última reforma publicada en el Diario Oficial de la Federación el 26 de febrero de 2013

CORREA, Flórez María Camila, Violencia sexual contra las mujeres en el conflicto armado: crimen de guerra y arma contraria al DIH, Revista № 49, Octubre-Diciembre, 2014, en: http://legal.legis.com.co/document.legis/violencia-sexual-contra-las-mujeres-en-elconflicto?documento=rpenal\&contexto=rpenal 0a6c2c68ea4901c2e0530a01015101c2\&vi $\underline{\text { sta }=S T D-P C}$

DEMUS, Estudio para la Defensa de los Derechos de la Mujer, Justicia de Género. Violencia sexual en conflictos armados: el derecho de las mujeres a la justicia, Agencia Española de Cooperación Internacional, Lima, septiembre de 2008

DONDÉ Matute, F. Javier, Derecho Penal Internacional, Editorial Oxford, México, 2008

ESTRADA, Adan Guillermo E. y FERNANDEZ, De Casadevante Roman Carlos, Derecho Internacional de los Derechos Humanos, Manual, Editorial Porrúa, México, 2014

FACIO, Alda, Cuando el género suena, cambios trae. Una metodología para el análisis de género del fenómeno legal, ILANUD, 1991

FAVAROTTO, Ricardo S, Justicia Penal Internacional, Editorial Ediar, Buenos Aires, Argentina, 2009

GARCÍA Muñoz, Soledad, Género y Derechos Humanos de las Mujeres: Estándares conceptuales y normativos en clave de derecho internacional, en Colección Género, Derecho y Justicia: Derechos de las Mujeres en Derecho Internacional, coordinadores Juan A. Cruz Parcero y Rodolfo Vásquez, editorial fontamara, segunda edición, México, 2012

GUARNIZO Peralta, Diana, Acceso a la justicia para mujeres víctimas de violencia sexual, Cuarto informe de seguimiento al Auto 092 de la Corte Constitucional, Colombia, 2011, en: http://www.pgr.gob.sv/genero/descargas/acceso a la justicia para mujeres.pdf

HARARI, Sofía y PASTORINO, L. Gabriela, Acerca del género y el derecho, en El Derecho en el Género y el Género en el Derecho, Editorial Biblos, Buenos aires, Argentina, 2000

Instituto Interamericano de Derechos Humanos y Centro por la Justicia y el Derecho Internacional, Los derechos humanos de las mujeres: Fortaleciendo su promoción y protección internacional, San José, Costa Rica, Agosto 2004

Instituto Interamericano de Derechos Humanos, La Protección de los Derechos de las Mujeres en el Sistema Interamericano de Derechos Humanos, 2004

----------------, Atención integral a víctimas de tortura en procesos de litigio, Aportes psicosociales, San José, Costa Rica, 2007 
JOSEPPH, Sarah, MITCHELL, Katie y GYORKY, Linda, Como hacer valer los derechos de las víctimas de la tortura; Un manual sobre los procedimientos de presentación e denuncias individuales ante los Órganos de tratados de las Naciones Unidas, Serie de manuales de la Organización Mundial contra la Tortura, OMCT, Vol. 4, Ginebra, 2006

LONG Debra, Guía de Jurisprudencia sobre tortura y malos tratos; el artículo 3 del Convenio Europeo de Derechos Humanos, Asociación para la prevención de la tortura (APT), Ginebra, junio 2002

MANTILLA Falcón, Julissa, La Comisión de la Verdad y Reconciliación en el Perú y la perspectiva de género: principales logros y hallazgos, en: http://www.convergemujeres.org/documentos/Campo\%20algodonero/Estandares\%20int ernacionales/IIDH/Comision\%20verdad\%20peru\%20y\%20genero.pdf

MEDINA Quiroga, Cecilia y NASH, Rojas Claudio, Manual de Derecho Internacional de Derechos Humanos, Centro de Documentación de Defensoría Penal Pública de Chile, 2003

, Derechos Humanos de la Mujer, ¿Dónde estamos ahora en las Américas?, Publicado en Essays in Honour of Alice Yotopoulos-Marangopoulos, Artículo traducido al castellano por el Centro de Derechos Humanos, Facultad de Derecho, Universidad de Chile, 2003

, La Convención Americana: Teoría y Jurisprudencia, vida, Integridad personal, Libertad personal, Debido proceso y Recurso Judicial, Centro de Derechos Humanos, Facultad de Derechos, Universidad de Chile, diciembre 2003

MOREYRA, María julia, Conflictos armados y violencia sexual contra mujeres, Editores del Puerto, Buenos Aires, 2007

MOVILLA Pateiro, Laura, Tratamiento Jurídico-Internacional del Uso de la Violación como Arma de Guerra: avances y retos, Trabajos y ensayos, número 11, Publicación del Master Universitario y del Doctorado de Estudios Internacionales, 2010 en: http://www.diprriihd.ehu.es/revistadoctorado/n11/Movilla11.pdf

MUÑOZ, Aunión Antonio, HINOJOSA, Cantú Carlos y SAíZ Zorrilla Alejandro, Introducción al Derecho Internacional Público, Editorial Porrúa, México, 2009

NUÑEZ Marín, Raúl Fernando y ZULUAGA Jaramillo, Lady Nancy, La violencia sexual como una forma de tortura en el derecho internacional de los derechos humanos, Criterio Jurídico, Santiago de Cali, V. 11, No. 1, 2011, en: http://revistas.javerianacali.edu.co/index.php/criteriojuridico/article/view/358/1225 
Oficina del Alto Comisionado para las Naciones Unidas, Comité de Derechos Humanos: Jurisprudencia, en: http://www.ohchr.org/EN/HRBodies/CCPR/Pages/CCPRIndex.aspx

Selección de decisiones del Comité contra la Tortura, volumen 1, Ginebra, 2008 en: http://www.ohchr.org/Documents/Publications/SDecisionsCATVollsp.pdf

----------------, Derecho Internacional de los Derechos Humanos, Normativa, Jurisprudencia y Doctrina de los Sistemas Universal e Interamericano, Bogotá Colombia, abril 2004

OROZCO, Sánchez César Alejandro, El Derecho Internacional de los Derechos Humanos y su recepción en México, editorial UBIJUS, México, 2012

Organización de los Estados Americanos, Corte Interamericana de Derechos Humanos, Historia, en: http://www.corteidh.or.cr/index.php/es/acerca-de/historia-de-la-corteidh

---------------, Comisión Interamericana de Derechos Humanos, Acerca de la Comisión Interamericana de Derechos Humanos, en: http://www.oas.org/es/cidh/mandato/que.asp

Organización de las Naciones Unidas, Información General, en: http://www.un.org/es/sections/about-un/overview/index.html

----------------, Compilación de las observaciones generales y recomendaciones generales adoptadas por órganos creados en virtud de tratados de derechos humanos, HRI/GEN/1/Rev. 5, 26 de abril de 2001

PALACIOS Zuloaga, Patricia, Las Convenciones Internacionales de Derechos Humanos y la Perspectiva de Género, Universidad de Chile, Primera edición, diciembre 2005

PLACENCIA, Villanueva Raúl, Sentencias de la Corte Interamericana de Derechos Humanos, Comisión Nacional de los Derechos Humanos, México, 2010

Pontificia Universidad Javeriana, La violencia sexual como arma de guerra frente al derecho internacional humanitario, Bogotá, Octubre 2002

Protocolo Internacional de documentación e investigación de violencia sexual en situaciones de conflicto armado, primera edición, junio 2014

RODRIGUEZ, Marcela, Algunas consideraciones sobre los delitos contra la integridad sexual de las personas, en Las Trampas del poder punitivo, el Género del Derecho Penal, Editorial Biblos, Buenos Aires, argentina, 2000

SILVA, García Fernando, Jurisprudencia Interamericana sobre Derechos Humanos, Criterios Esenciales, editorial Tirant Lo Blanch México, 2012

Tribunal Penal Internacional para la ex Yugoslavia, About de the ICTY y The cases en: http://www.icty.org/sections/AboutthelCTY 
Tribunal Penal Internacional para Ruanda, About the ICTR y The cases, en: http://www.unictr.org/en/tribunal

VALLARTA, Marrón José Luis, Derecho Internacional Público, Editorial Porrúa, México, 2006

VASQUEZ, Camacho Santiago J., La respuesta del Estado frente a los feminicidios y la violencia contra las mujeres en razón del género conforme al Sistema Interamericano de Promoción y Protección de los Derechos Humanos, en Colección Género, Derecho y Justicia: Las Mujeres a través del Derecho Penal, coordinadores Juan A. Cruz Parcero y Rodolfo Vásquez, editorial fontamara, segunda edición, México, 2012

VILLELLAS Ariño, María, La violencia sexual como arma de guerra, septiembre 2010, en: http://escolapau.uab.es/img/qcp/violencia_sexual_guerra.pdf

VISEUR Sellers, Patricia, Procesos penales sobre violencia sexual en conflicto: La importancia de los derechos humanos como medio de interpretación, en: http://webcache.googleusercontent.com/search?q=cache:nIMz4mLyuAsJ:www2.ohchr.org lenglish/issues/women/docs/Paper Prosecution of Sexual Violence sp.doc $\& c d=1 \& h l=e$ $s \& c t=c \ln k \& g l=m x$

W. SCOTT, Joan, El Género: Una categoría útil para el análisis histórico, Materiales de Enseñanza, Género: conceptos básicos, 1990

\section{INFORMES}

Amnistía Internacional, Fuera de control, Tortura y otros malos tratos en México, 2014 México: Muertes intolerables, Diez años de desapariciones y asesinatos de mujeres en Ciudad Juárez y Chihuahua, AMR 41/027/2003

, Informe Mujeres Indígenas e Injusticia Militar, México, 23 de noviembre de

2004

Comisión Nacional de los Derechos Humanos, Informe Especial sobre los Casos de Homicidios y Desapariciones de Mujeres en el Municipio de Juárez, Chihuahua, 2003 , Recomendación 44/1998, emitida el 15 de mayo de 1998

OEA, Comisión Interamericana de Derechos Humanos, Acceso a la Justicia para Mujeres Víctimas de Violencia Sexual en Mesoamérica, OEA/Ser.L/V/II., 09 de diciembre de 2011

, Comisión Interamericana de Derechos Humanos, Situación de los Derechos de la Mujer en Ciudad Juárez, México: El Derecho a No Ser Objeto de Violencia y Discriminación, OEA/Ser.L/V//II.117, 7 de marzo de 2003 
-, Comisión Interamericana de Derechos Humanos, Informe Anual 1997, Capítulo VI. Informe sobre la Condición de la Mujer en las Américas, 1997

-, Comisión Interamericana de Derechos Humanos, Informe sobre la condición de la mujer en las Américas, OEA/Ser.L/V/II.100, 13 octubre 1998

, Comisión Interamericana de Derechos Humanos, Acceso a la justicia para las mujeres víctimas de violencia en las Américas, OEA, Ser.L/V/II., enero 2007

ONU, Informe presentado por la Sra. Radhika Coomarasway, Relatora Especial sobre la violencia contra la mujer, con inclusión de sus causas y consecuencias, de conformidad con la resolución 2000/45, E/CN.4/2001/73, "La violencia contra la mujer perpetrada y/o condonada por el Estado en tiempos de conflicto armado (1997-2000)", 23 de enero de 2001.

- Informe presentado por la Sra. Radhika Coomarasway, Relatora Especial sobre la violencia contra la mujer, con inclusión de sus causas y consecuencias, de conformidad con la resolución 1997/44 de la Comisión, E/CN.4/1998/54, 26 de enero de 1998

---------------, Informe de la Sra. Radhika Coomaraswamy, Relatora Especial sobre la violencia contra la mujer, con inclusión de sus causas y consecuencias; La violencia contra la mujer en la familia, E/CN.4/1999/68, 10 de marzo de 1999

, Informe presentado por la Sra. Radhika Coomarasway, Relatora Especial sobre la violencia contra la mujer, con inclusión de sus causas y consecuencias, Integración de los derechos humanos de la mujer y la perspectiva de género; La violencia contra la mujer, E/CN.4/2003/75, 6 de enero de 2003

, Informe de México producido por el Comité para la Eliminación de la Discriminación a la mujer, CEDAW/C/2005/OP.8/MEXICO, 27 de enero de 2005

ONU, Informe de la Relatora Especial sobre la violencia contra la mujer, sus causas y consecuencias, Yakin Ertürk, Integración de los Derechos Humanos de la Mujer y la Perspectiva de Género: La Violencia contra la Mujer, Misión a México, E/CN.4/2006/61/Add.4, 13 de enero de 2006

----------, Informe del Relator Especial Mr. P. Kooijmans, Tortura y otros Tratos o Penas Crueles, Inhumanas o Degradantes, E./CN.4/1986/15, 19 de febrero de 1986

-, Informe del Relator Especial Mr. Nigel S. Rodley, Cuestión de los Derechos Humanos de todas las personas sometidas a cualquier forma de detención o prisión y en particular: La Tortura y otros tratos o penas crueles, inhumanas y degradantes, E/CN.4/1994/31, 6 de enero de 1994

, Informe del Relator Especial Mr. P. Kooijmans, Tortura y otros tratos o penas crueles, inhumanas y degradantes, E/CN.4/1986/15, 16 de febrero de 1986 


\section{TRATADOS INTERNACIONALES}

Estatuto del Tribunal Penal Internacional para la Ex Yugoslavia, del 25 de mayo de 1993

Estatuto del Tribunal Penal Internacional para Ruanda, del 08 de noviembre de 1994

Estatuto de Roma de la Corte Penal Internacional, 17 de julio de 1998

OEA, Convención Americana sobre Derechos Humanos, adoptada en 1969 en San José, Costa Rica

OEA, Convención Interamericana para Prevenir, Sancionar y Erradicar la Violencia contra las Mujeres, adoptada en 1994 en Belém do Pará, Brasil

OEA, Convención Interamericana para Prevenir y Sancionar la Tortura, adoptada en 1985 en Cartagena de Indias, Colombia

ONU, Pacto Internacional de Derechos Civiles y Políticos, adoptado en 1966 en Nueva York

ONU, Convención sobre los Derechos del Niño, adoptada en 1989 en Nueva York

ONU, Convención sobre la Eliminación de todas las formas de Discriminación contra la Mujer, adoptada en 1979 en Nueva York

ONU, Convención contra la Tortura y Otros Tratos o Penas Crueles, Inhumanos o Degradantes, adoptada en 1984 en Nueva York

\section{DECLARACIONES}

ONU, Declaración Universal de Derechos Humanos, adoptada en 1948 en París

OEA, Declaración Americana de Derechos y Deberes del Hombre, adoptada en 1848 en Bogotá, Colombia

ONU, Declaración sobre la Eliminación de la Violencia contra la Mujer, adoptada en 1993

ONU, Declaración sobre la Protección de Todas la Personas contra la Tortura y Otros Tratos o Penas Crueles, Inhumanos y Degradantes, adoptada en 1975

\section{DOCUMENTOS}

OEA, Corte Interamericana de Derechos Humanos, Opinión Consultiva OC-14/94, Responsabilidad Internacional por expedición y aplicación de leyes violatorias de la Convención (Arts. 1y 2 de la Convención Americana sobre Derechos Humanos), 09 de diciembre de 1994 
ONU, Comité de Derechos Humanos, Observación General No. 3 "Artículo 2, aplicación del Pacto a nivel nacional", $13^{\circ}$ periodo de sesiones

ONU, Comité de Derechos Humanos, Observación general No. 20, Artículo 7, 44 período de sesiones (1992)

ONU, Comité de Derechos Humanos, Observación General No. 31, "Naturaleza de la obligación jurídica general impuesta a los Estados Partes en el Pacto", 80 periodo de sesiones

ONU, Comité para la Eliminación de Todas las Formas de Discriminación Contra la Mujer, Recomendación General No. 19, $11^{\circ}$ periodo de sesiones, 1992, U.N. Doc. HRI $\backslash G E N \backslash 1 \backslash R e v .1$ at 84 (1994).

ONU, Comité para la Eliminación de Todas las Formas de Discriminación Contra la Mujer, Recomendación General N²5

ONU, Comité Contra la Tortura, Observación General No. 2 sobre aplicación del artículo 2 por los Estados Partes, CAT/C/GC/2, 24 de enero de 2008

ONU, Consejo de Seguridad, S/RES/827 (1993), aprobada por el Consejo de Seguridad en su $3217^{\circ}$ sesión, celebrada el 25 de mayo de 1993

ONU, Consejo de Seguridad, S/RES/955 (1994), Aprobada por el Consejo de Seguridad en su $3453^{\circ}$ sesión, celebrada el 08 de noviembre de 1994

ONU, Reglas mínimas para el tratamiento de los reclusos, Adoptadas por el Primer Congreso de las Naciones Unidas sobre Prevención del Delito y Tratamiento del Delincuente, celebrado en Ginebra en 1955, y aprobadas por el Consejo Económico y Social en sus resoluciones 663C (XXIV) de 31 de julio de 1957 y 2076 (LXII) de 13 de mayo de 1977

\section{SENTENCIAS}

Corte Europea de Derechos Humanos, Caso Aydin Vs. Turquía, Sentencia del 25 de septiembre de 1997

, Caso Irlanda Vs. Reino Unido, Sentencia del 18 de enero de 1978

, Caso M.C. v. Bulgaria, Sentencia de 04 de diciembre de 2003

OEA, Corte Interamericana de Derechos Humanos, Caso Velásquez Rodríguez Vs. Honduras, Sentencia de 29 de julio de 1988, Fondo

Fondo

Caso Loayza Tamayo Vs. Perú, Sentencia de 17 de septiembre de 1997, 
Caso de los "Niños de la Calle" (Villagrán Morales y otros Vs. Guatemala), Sentencia de 19 de noviembre de 1999, Fondo

-------------, Caso Cantoral Benavides Vs. Perú, Sentencia de 18 de agosto de 2000, Fondo

-------------, Caso Maritza Urrutia Vs. Guatemala, Sentencia de 27 de noviembre de 2003, Fondo, Reparaciones y Costas

, Caso 19 Comerciantes Vs. Colombia, Sentencia del 5 de julio de 2004, Fondo, Reparaciones y Costas

------, Caso Tibi Vs. Ecuador, Sentencia de 7 de septiembre de 2004, Excepciones Preliminares, Fondo, Reparaciones y Costas

-------------, Caso De la Cruz Flores Vs. Perú, Sentencia de 18 de noviembre de 2004, Fondo, Reparaciones y Costas

, Caso Lori Berenson Mejía Vs. Perú, Sentencia de 25 de noviembre de 2004, Fondo, Reparaciones y Costas

, Caso de la Masacre de Pueblo Bello Vs. Colombia, Sentencia de 31 de enero de 2006, Fondo, Reparaciones y Costas

, Caso Comunidad Indígena Sawhoyamaxa Vs Paraguay, Sentencia de 29 de marzo de 2006, Fondo, Reparaciones y Costas

, Caso Baldeón García Vs. Perú, Sentencia de 6 de abril de 2006, Fondo, Reparaciones y Costas

, Caso Montero Aranguren y otros (Retén de Catia) Vs. Venezuela, Sentencia de 5 de julio de 2006, Excepciones Preliminares, Fondo, Reparaciones y Costas

-------------, Caso del Penal Miguel Castro Castro Vs. Perú, Sentencia de 25 de noviembre de 2006, Fondo, Reparaciones y Costas

, Caso Bueno Alves Vs. Argentina, Sentencia de 11 de mayo de 2007, Fondo, Reparaciones y Costas

-, Caso Bayarri Vs. Argentina, Sentencia de 30 de octubre de 2008, Excepción Preliminar, Fondo, Reparaciones y Costas

-------, Caso González y otras ("Campo Algodonero") Vs. México, Sentencia de 16 de noviembre de 2009, Excepción preliminar, Fondo, Reparaciones y Costas

, Caso Radilla Pacheco Vs México, Sentencia de 23 de Noviembre de 2009, Excepciones Preliminares, Fondo, Reparaciones y Costas, 
, Caso Vélez Loor Vs. Panamá, Sentencia de 23 de noviembre de 2010, Excepciones Preliminares, Fondo, Reparaciones y Costas

--------------, Caso J Vs. Perú, Sentencia de 27 de noviembre de 2013, Excepción Preliminar, Fondo, Reparaciones y Costas

Tribunal Penal Internacional para Ruanda, Caso No. TPIR-96-4-T, el Fiscal contra Jean-Paul Akayesu, Sentencia del 02 de septiembre de 1998, Fallo de la Sala de Primera Instancia

Tribunal Penal Internacional para la Ex Yugoslavia, Caso No. IT-95-17/1-PT, el fiscal contra Funrundzija, Sentencia del 10 de diciembre de 1998, Fallo de la Sala de Primera Instancia

-----------, Caso No. IT-96-23/1-A, el Fiscal contra Dragoljub Kunarac, Radomir Kovac y Zoran Vukovic, Sentencia del 12 de junio del 2002 Fallo de la Sala de Primera Instancia -, Caso No IT-95-14/1-T, el Fiscal contra Aleksovski, Sentencia del 25 de junio de 1999, Fallo de la Sala de Primera Instancia

, Caso Celebici, Caso No. IT-96-21-T, Sentencia 16 de noviembre de 1998, Fallo de la Sala de Primera Instancia

\section{RECOMENDACIONES}

OEA, Comisión Interamericana de Derechos Humanos, Caso Rosa Marta Cerna Alfaro Vs El Salvador, Informe Anual 1991, Informe N 10/92, Caso 10.257, 04 de febrero de 1992

--------------, Caso Flor de María Hernández Rivas Vs. El Salvador, Informe N 7/94, Caso 10.911, 01 de febrero de 1994

---------, Caso Comadres Vs El Salvador, Informe de admisibilidad y fondo 13/96, Caso 10.948, 01 de marzo de 1996

-----------, Caso Dianna Ortiz VS Guatemala, Informe de Fondo 31/96, Caso 10.526, del 16 de octubre de 1996,

-------------, Caso Ana, Beatriz y Celia González Pérez Vs México, informe de fondo 53/01, 04 de abril de 2001

----------------, Caso Gladys Carol Espinoza Gonzales Vs. Perú, Informe de Admisibilidad y Fondo 67/11, Caso 11.157, del 31 de marzo de 2011

-, Caso Raquel Martín de Mejía Vs. Perú, Informe N 5/96, Caso 10.979, $1^{\circ}$ de marzo de 1996

, Caso Ana, Beatriz y Celia González Pérez Vs. México, Informe de fondo № 53/01, caso 11.565, 04 de abril de 2001 
, Demanda ante la Corte Interamericana de Derechos Humanos, Caso Valentina Rosendo Cantú y otra Vs. México, Caso 12.579, 2 de agosto de 2009

-------------, Demanda ante la Corte Interamericana de Derechos Humanos, Caso Inés Fernández Ortega Vs México, Caso 12.580, 7 de mayo de 2009

--------------, Inés Fernández Ortega y otros Vs México, Informe de Admisibilidad № 94/06, Petición 540/04

Valentina Rosendo Cantú y otros Vs México, Informe de Admisibilidad № 93/06, Petición 972-03

\section{RESOLUCIONES}

ONU, Comité Contra la Tortura, Comunicación № 59/1996, Encarnación Blanco Abad Vs. España

, Comunicación № 8/1991 Qani Halimi-Nedzibi Vs. Austria

, Comunicación № 13/1993 Balabou Mutombo Vs. Suiza

, Comunicación № 34/1995 Seid Mortesa Aemei Vs. Suiza

, Comunicación № 43/1996 Kaveh Yaragh Tala Vs. Suecia

, Comunicación № 39/1996 Gorki Ernesto Tapia Páez Vs. Suecia

, Comunicación № 59/1996 Encarnación Blanco Abad Vs. España

, Comunicación № 63/1997 Josu Arkauz Arana Vs. Francia

, Comunicación № 99/1997 T. P. S. Vs. Canadá

, Comunicación № 110/1998 Cecilia Rosana Núñez Chipana Vs. Venezuela

-, Comunicación № 113/1998 Ristic Vs. Yugoslavia

, Comunicación № 120/1998 Sadiq Shek Elmi Vs. Australia

, Comunicación № 161/2000 Hajrizi Dzemajl y otros Vs. Yugoslavia

, Comunicación № 171/2000 Jovica Dimitrov Vs. Serbia y Montenegro

, Comunicación № 172/2000 Danilo Dimitrijevic Vs. Serbia y Montenegro

-, Comunicación № 181/2001 Suleymane Guengueng y otros Vs. el Senegal

, Comunicación № 187/2001 Dhaou Belgacem Thabti Vs. Túnez

, Comunicación № 188/2001 Imed Abdelli Vs. Túnez

, Comunicación № 189/2001 Bouabdallah Ltaief Vs. Túnez

, Comunicación № 195/2002 Mafhoud Brada Vs. Francia

, Comunicación № 207/2002 Dragan Dimitrijevic Vs. Serbia y Montenegro 
-----------------, Comunicación № 212/2002 Kepa Urra Guridi Vs. España

, Comunicación № 214/2002 M. A. K. Vs. Alemania

-, Comunicación № 219/2002 G. K. Vs. Suiza

-, Comunicación № 233/2003 Ahmed Hussein Mustafa Kamil Agiza Vs.

Suecia

, Comunicación № 238/2003 Z. T. Vs. Noruega

, Comunicación 258/2004 Mostafa Dadar Vs. Canadá

, Comunicación № 262/2005 V. L. Vs. Suiza

, Comunicación № 279/2005 C. T. y K. M. Vs. Suecia

, Comunicación № 280/2005 Gamal El Rgeig Vs. Suiza

, Comunicación № 282/2005 S. P. A. Vs. Canadá

, Comunicación № 300/2006 Adel Tebourski Vs. Francia

ONU, Comité para la Eliminación de la Discriminación contra la Mujer, Comunicación No. 1/2003, Sra. B.-J. contra Alemania

-----------, Comunicación No. 2/2003, Sra. A. T. contra Hungría

---------------, Comunicación No. 3/2004, Dung Thi Thuy Nguyen contra The Netherlands

-------------, Comunicación No. 4/2004, A.S. contra Hungría

---------, Comunicación No. 5/2004, Sahide Goekce contra Austria

-----------, Comunicación No. 6/2004, Fatma Yildirim contra Austria

---------------, Comunicación No. 7/2004, Cristina Muñoz-Vargas y Sainz de Vicuña contra España

-----------, Comunicación No. 8/2004, Rahime Kayhan contra Turquia

---------, Comunicación No. 10/2004, Sra. N. F. S. contra Reino Unido de Gran Bretaña e Irlanda del Norte

------------, Comunicación No. 11/200, Sra. Constance Ragan Salgado contra Reino Unido de Gran Bretaña e Irlanda del Norte 


\section{SIGLAS EMPLEADAS}

ONU

ECOSOC

OEA

SI

PIDCP

$\mathrm{CADH}$

CEDAW

Convención Belém

Do Pará

Convención de la

ONU

CIPST o Convención Interamericana

CIDH o Comisión

CoIDH o Corte

TPIY

TPIR

HVO

$\mathrm{ABiH}$

MRTA

EZLN

DIRCOTE

DIVISE

DINCOTE

Sendero Luminoso

DINOES

CVR

ETA
Organización de las Naciones Unidas

Consejo Económico y Social

Organización de los Estados Americanos

Sistema Interamericano

Pacto Internacional de Derechos Civiles y Políticos

Convención Americana sobre Derechos Humanos

Convención sobre la Eliminación de todas las formas de Discriminación contra la Mujer

Convención Interamericana para Prevenir, Sancionar y Erradicar la Violencia contra las Mujeres

Convención contra la Tortura y Otros Tratos o Penas Crueles, Inhumanos y Degradantes

Convención Interamericana para Prevenir y Sancionar la Tortura

Comisión Interamericana de Derechos Humanos

Corte Interamericana de Derechos Humanos

Tribunal Penal Internacional para la Ex Yugoslavia

Tribunal Penal Internacional para Ruanda

Consejo de Defensa de Croacia

Ejército de Bosnia y Herzegovina

Movimiento Revolucionario Tupac Amaru

Ejército Zapatista de Liberación Nacional

Dirección Contra el Terrorismo

División de Investigación de Secuestro

Dirección Nacional contra el Terrorismo

Partido Comunista del Perú

Dirección Nacional de Operaciones Especiales de la Policía Nacional del Perú

Comisión de la Verdad y Reconciliación de Perú

Banda armada Euskadi Ta Askatasuna 